\title{
Experimental Measurement of Effective Diffusion Coefficient of Gas Diffusion Layer/Microporous Layer in PEM Fuel Cells
}

by

Carl Chan

\author{
A thesis \\ presented to the University of Waterloo \\ in fulfillment of the \\ thesis requirement for the degree of \\ Master of Applied Science \\ in \\ Mechanical Engineering
}

Waterloo, Ontario, Canada, 2011

(C) Carl Chan 2011 


\section{AUTHOR'S DECLARATION}

I hereby declare that I am the sole author of this thesis. This is a true copy of the thesis, including any required final revisions, as accepted by my examiners.

I understand that my thesis may be made electronically available to the public.

Carl Chan 


\begin{abstract}
Accuracy in the effective diffusion coefficient of the gas diffusion layer $(\mathrm{GDL}) /$ microporous layer (MPL) is important to accurately predict the mass transport limitations for high current density operation of polymer electrolyte membrane (PEM) fuel cells. All the previous studies regarding mass transport limitations were limited to pure GDLs, and experimental analysis of the impact of the MPL on the overall diffusion in the porous GDL is still lacking. The MPL is known to provide beneficial water management properties at high current operating conditions of PEM fuel cells but its small pore sizes become a resistance in the diffusion path for mass transport to the catalyst layer. A modified Loschmidt cell with an oxygen-nitrogen mixture is used in this work to determine the effect of MPL on the effective diffusion coefficients. It is found that Knudsen effects play a dominant role in the diffusion through the MPL where pore diameters are less than $1 \mu \mathrm{m}$. Experimental results show that the effective diffusion coefficient of the MPL is only about $21 \%$ that of its GDL substrate and Knudsen diffusion accounts for $80 \%$ of the effective diffusion coefficient of the GDL with MPL measured in this study. No existing correlations can correlate the effective diffusion coefficient with significant Knudsen contribution.
\end{abstract}




\section{Acknowledgements}

This thesis would not have been successful without the help of many individuals who provided guidance, knowledge and/or support throughout the various obstacles along the way.

First and foremost, I would like to thank my dear mother and father for pretty much everything. I would also like to thank the following individuals: Professor Xianguo Li for his patience and technical knowledge, not to forget the opportunity and experience he bestowed along the way, Nada Zamel for her enthusiastic mentorship and for providing help generously out of her own time, Dr.Yongtaek Lee for providing the pore size measurements, Colleagues from the 20/20 Laboratory for Fuel Cell and Energy RD\&D for their constructive feedback and opinions, Neil Griffett for his technical expertise in electronics and LabView controls, Jason Benninger for his professional design and machining skills; providing solutions to the mechanical issues, Professor Michael Fowler for providing background support and access to literature of his own, and last but not least, Joyce Lam for her understanding, patience, support and trust.

The support from AUTO21 Network of Centres of Excellence and Natural Sciences and Engineering Research Council (NSERC) of Canada is gratefully acknowledged. SolviCore GmbH \& Co. KG is highly appreciated for providing SolviCore GDLs used in this study. 


\section{Dedication}

To my parents, William and Fanny, who had always encouraged me to pursue higher education and sacrificed so much of their energy to ensure that I would receive the support I needed to get there. Thanks mom and dad. 


\section{Table of Contents}

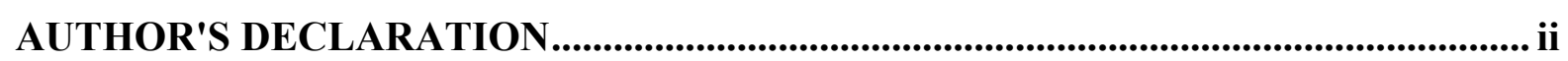

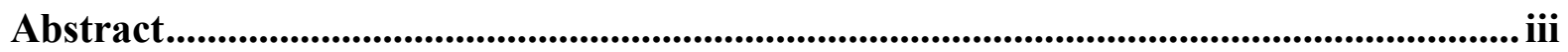

Acknowledgements .............................................................................................................................. iv

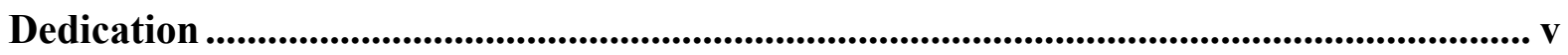

Table of Contents ..............................................................................................................

List of Figures................................................................................................................................. viii

List of Tables

Chapter 1 Introduction................................................................................................................ 1

1.1 Operating Principle of the PEM Fuel Cell ............................................................. 3

1.2 Carbon Paper Gas Diffusion Layer ....................................................................... 7

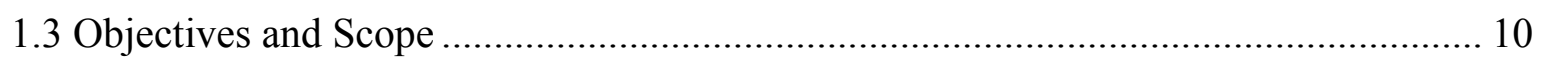

Chapter 2 Literature Review .......................................................................................................... 11

2.1 Experimental Techniques ........................................................................................ 15

Chapter 3 Principle of Measurement........................................................................................ 21

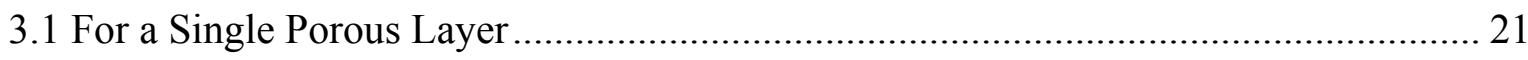

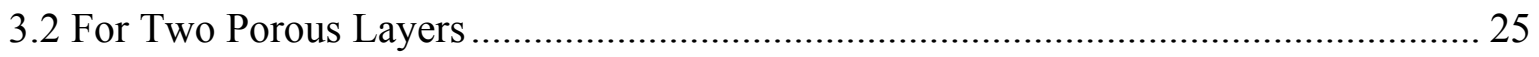

3.3 For Porous Layer of Small Pore Sizes ………………………………………..... 26

Chapter 4 Method Selection and Apparatus Design ............................................................... 28

4.1 Validation of the Apparatus ....................................................................................... 31

4.1.1 Areas of Uncertainty Using the Closed-Tube Method ........................................... 31

4.1.2 System Environment and Settings .................................................................. 32 


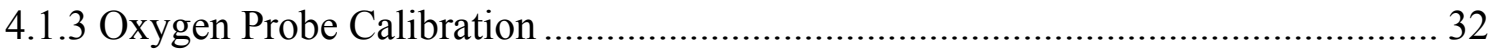

4.1.4 Gas Containment Ability of Apparatus ............................................................... 34

4.1.5 H-calibration and Bulk Diffusion Coefficient Measurements.............................. 35

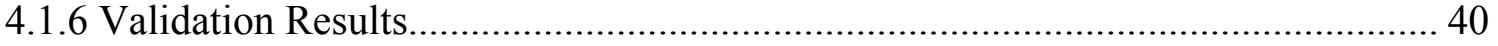

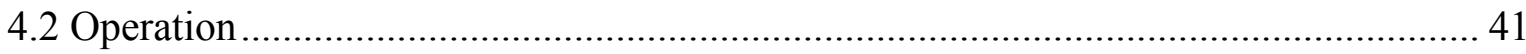

Chapter 5 GDL Sample Measurements .............................................................................. 44

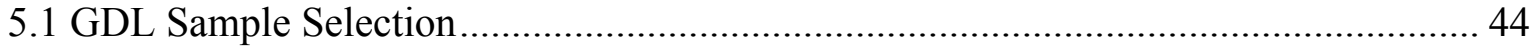

5.2 Equivalent Diffusion Coefficient Measurements ................................................ 47

Chapter 6 Discussion .............................................................................................................5 50

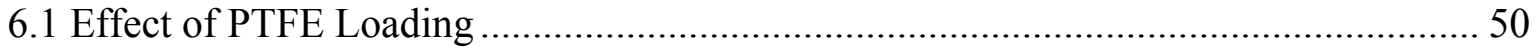

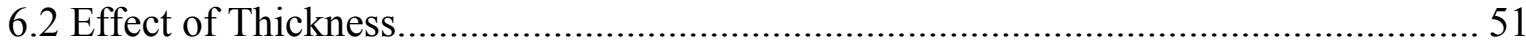

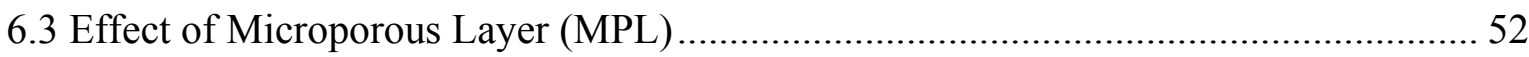

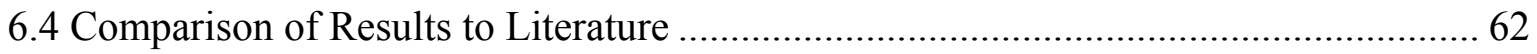

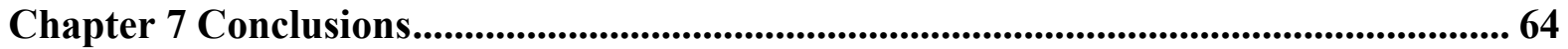

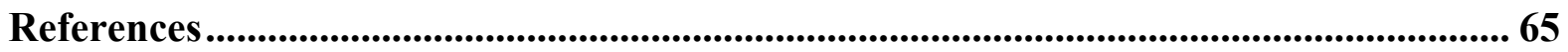

Appendix A Schematic Drawings for Diffusion Cell ...................................................... 74

Appendix B Binary Diffusion Coefficients for Measured and Calculated Values.......... 95

Appendix C LabView Code for Diffusion Apparatus .................................................. 96

Appendix D Porosity Measurements for GDL Samples............................................. 101

Appendix E Effective Diffusion Coefficient Measurements........................................... 108

Appendix F SEM Images for MPL Thickness ........................................................ 124 


\section{List of Figures}

Figure 1.1 - Typical components of a single PEM fuel cell unit. ............................................ 4

Figure 1.2 - Polarization curve of PEM fuel cell. A: Activation Polarization, B: Ohmic Polarization, and C: Concentration Polarization.................................................. 6

Figure 1.3 - Images of carbon paper (left) and carbon cloth (right) from Scanning Electron Microscope (SEM) [26].................................................................... 8

Figure 2.1 - Comparison of conventional correlations and Zamel et al.'s [70] model for the diffusibility of porous media. It can be seen that conventional correlations tend to over-predict mass transport [69]. 15

Figure 2.2 - The through-plane and in-plane directions of the GDL are shown schematically and the SEM images [70] of each section illustrate its anisotropic structure. 16

Figure 2.3 - Electrochemical diffusimetry experimental apparatus used by Kramer et al. [77] and Flückiger et al. [78] Left: Through plane, Right: In-plane.

Figure 2.4 - Modified Loschmidt cell used by Zamel et al. [72] and Astrath et al. [79] ..... 18

Figure 2.5 - Modified fuel cell used by Quick et al. [81] with a hydrophilic polyamide non-woven which soaked up the liquid water from the "water side" flow channel to transfer through the catalyst-coated membrane and gas diffusion layer to exit at the "gas side" flow channel

Figure 2.6 - Casalegno et al. [82] used a single straight channel with co-current dry and humid air flow.

Figure 2.7 - LaManna et al. [83] used a single straight channel with two parallel humidified air streams.

Figure 3.1 - Illustration of infinitely long cylinder used for derivation of general diffusion equation for short periods of time.

Figure 3.2 - Illustration of the measured species concentration and curve fitting by Eq. (3.3) in determining the equivalent diffusion coefficient.

Figure 3.3 - Resistance network for one thin porous layer. 24

Figure 3.4 - Resistance network for two thin porous layers. 25

Figure 4.1 - Schematic of the modified Loschmidt cell for the measurement of effective diffusion coefficient. 1: gas inlet 1; 4 : gas inlet $4 ; 2,3$ and 5 : outlets; 6 : sliding gate valve; $6(\mathrm{a})$ : open position of the valve; $6(\mathrm{~b})$ : closed position of the valve; 7: oxygen probe; 8 and 9: thermocouples; 10: sample holder. 
Figure 4.2 - Calibration curve of the oxygen probe from $0-50 \%$ for room temperature. ...... 33

Figure 4.3 - Oxygen concentration in the nitrogen chamber after the nitrogen purging and before the diffusion process.

Figure 4.4 - This chart illustrates that there is minimal change in the oxygen gas temperature $\left(\sim 0.3^{\circ} \mathrm{C}\right)$ during the diffusion process and therefore an average oxygen temperature value can be taken.

Figure 4.5 - This chart illustrates that there is negligible change in the room pressure during one measurement and therefore an average pressure can be taken.

Figure 4.6 - This chart shows that as room pressure changes, the partial pressure of oxygen changes thus reducing the oxygen concentration measured by the oxygen sensor.

Figure 4.7 - Comparison of the binary diffusion coefficients measured experimentally to those determined from Eq. (4.1) with 5.2\% upper and lower bounds.

Figure 6.1 - Effect of PTFE loading on the effective diffusion coefficient in the through-plane direction.

Figure 6.2 - Effect of the sample thickness on the measured diffusibility. Toray samples with the same PTFE loading but different thicknesses demonstrate no thickness effect. The $60 \%$ PTFE sample does not portray this because the average porosity between the two samples are about $10 \%$ apart, resulting in significant difference in the measured value.

Figure 6.3 - Cross-sectional view of SolviCore Type A sample with microporous layer (MPL) prepared by free-fracture in liquid nitrogen.

Figure 6.4 - Microporous layer (MPL) thickness distribution obtained from several SEM images for SolviCore Type A sample with MPL. The average thickness from the distribution is $66.4 \mu \mathrm{m}$

Figure 6.5 - Diffusivity vs. porosity for all samples measured in this work compared with the experimental work of others found in literature for through-plane diffusion. Also shown is the Bruggeman correlation and the numerical model by Zamel et al. [70]. The three outlying data points represent the three GDL samples which contain microporous layer (MPL) 56

Figure 6.6 - Pore size distribution for SolviCore Type A sample with microporous layer (MPL) obtained using Method of Standard Porosimetry. The peaks on the left represent the pore diameters in the MPL which ranges from $7 \mathrm{~nm}$ to $133 \mathrm{~nm}$.

Figure 6.7 - Comparison of diffusibility and thickness for SolviCore Type A series. The microporous layer of the sample has an average thickness of $66.4 \mu \mathrm{m}$ rather 
than $40 \mu \mathrm{m}$ due to its penetration into the substrate. Thickness effect appears to play a role in the presence of a microporous layer.

Figure 6.8 - SEM cross section of samples (prepared by freeze fracture in liquid nitrogen) containing microporous layer to illustrate a difference in layer thickness. Left: $38.4 \mu \mathrm{m}$ average (Sigracet ${ }^{\circledR} 25$ DC), Right: $60.7 \mu \mathrm{m}$ average (SolviCore Type B, MPL).

Figure 6.9 - Comparison of diffusibility and thickness for samples with microporous layer. Thickness does not have an apparent and significant effect when samples with microporous layer are compared with each other. 62 


\section{List of Tables}

Table 2.1 - Summary of conventional correlations and numerical models available to determine the effective diffusion coefficient of porous media.---------------- 14

Table 5.1 - Summary of GDL sample selection and other technical characteristics.----------45

Table 5.2 - Comparison of microstructure for some GDL samples taken from SEM. --------46

Table 5.3 - Summary of measured results for Toray samples. ------------------------------48

Table 5.4 - Summary of measured results for SolviCore samples. ------------------------48

Table 5.5 - Summary of measured results for SGL Sigracet ${ }^{\circledR}$ samples. --------------------49

Table 6.1 - Comparison of the effective diffusion coefficient of the microporous layer to that of the GDL substrate (on which the coating was applied to) and to the effective diffusion coefficient of the GDL and MPL combined. -------------55

Table 6.2 - Knudsen diffusion coefficient calculated from Eq. (3.13) and the corresponding pore diameter calculated from Eq. (3.14) 


\section{Chapter 1}

\section{Introduction}

In 1956, M. King Hubbert, introduced a model to predict the fossil fuel reserves consumption known as Hubbert's curve. He warned about a terminal decline of global oil reserves by the year 2006 [1] but it had failed to make any significance at that time. After much delay, the situation unfolds and people begin to acknowledge his model as they witnessed its accuracy in predicting the US peak oil in 1971, known as Hubbert's peak.

For the longest time, mankind has been increasing its energy demand for the purposes of improving the quality of life. Developing nations are trying to industrialize, while others are aiming for personal growth in all aspects. An abundant amount of statistics shows that the global energy demands are increasing exponentially with time and these researchers also predict that based on the current trends of consumption and population growth, another energy crisis is expected to appear in the near future [2-4]. Historically, most of the world's energy demands are met by the consumption of fossil fuels, such as petroleum for transportation, coal for power plants, and natural gas for homes. Depleting fossil fuel reserves are no longer a myth, but a global issue which must be addressed immediately for the well-being of future generations.

The general public appears to be aware of the energy crisis and environmental situation and some lifestyle alterations can be observed such as the switch to utilize energy efficient appliances for conservation and increased adoption of hybrid vehicles to reduce petroleum consumption. Corporate companies and institutions are also significant contributors and supporters for the amendment by initiating research and development efforts in "Green" technologies and renewable or alternative energy. Fuel cells, wind energy, solar power and bio-fuels are just some of the major R\&D topics that can be found in many countries today. Lastly, without the help of government support to aid these projects and to encourage participation, to enforce public policies for controlling emissions and limiting consumption of natural resources, and to establish communal goals, many of these efforts would not be possible. 
The development of automotive technology and its penetration into the Canadian market is a great example of the transition to reduced fossil fuel consumption and tailpipe emissions, and how each of the three key players executes a dominant role.

With the beginning of mandatory tailpipe emission tests in Ontario for most on-road vehicles, drivers of vehicles failing to meet test standards are denied licence plate renewals until tests are satisfied. The purpose of these tests is to limit vehicle emissions and to force unqualified vehicles with traditional internal combustion engine (ICE) power-train off the roads until they are fixed to meet minimum standards. Subsequently, Environment Canada sponsored a program known as 'Retire Your Ride' (similarly the federal U.S. government sponsored Car Allowance Rebate System (CARS)) to provide incentives to owners trading in less fuel-efficient vehicles.

Meanwhile, automakers are introducing gasoline hybrid electric vehicle technologies which promise better fuel efficiency and low emissions to consumers. Their relatively higher capital cost than non-hybrid models are justified with additional incentives such as government rebate programs, exemption from emission tests, and lower insurance rates. The combination of efforts at each level has driven the sales of such hybrid vehicles, but unfortunately, this is not enough.

Gasoline hybrid electric vehicles are a stepping stone to wane society's reliance on fossil fuels, but the ultimate solution involves a clean, renewable energy source. Researchers are now developing full electric and fuel cell hybrid electric vehicles as a long term solution.

The Polymer Electrolyte Membrane (PEM) fuel cell has become a popular topic in alternative, green energy technologies recently and is considered one of the most promising clean power sources for portable, stationary and mobile applications. It is an electrochemical device that converts chemical energy from reactants (such as hydrogen and air) and produces electrical energy, heat and water as a by-product. For the automobile, it is theoretically an excellent device because it produces zero toxic and green-house-gas tailpipe emissions, performs more efficiently than the traditional ICE, and is compatible with alternative/renewable energy sources. 
Realistically speaking however, more research efforts and public acceptance is necessary before they can become a threat to the considerably mature ICE technology. The PEM fuel cell encompasses desirable characteristics that make it a promising technology and a contributor to the global energy solution but its viability, efficiency, and robustness depends on understanding, predicting, monitoring and controlling the fuel cell system under a variety of environmental conditions and a wide operating range [5].

\subsection{Operating Principle of the PEM Fuel Cell}

Most "Green" technologies are not necessarily new but are revisited or reconsidered as it appears appropriate to the demand. The PEM fuel cell is no exception. It was invented at General Electric in the early 1960's by Thomas Grubb and Leonard Niedrach, initially for the U.S. Navy and Army [6]. The technology was later adopted by NASA's Gemini Project, but only recently has it received widespread attention on terrestrial grounds, some 50 years later.

On paper, the PEM fuel cells general working principles are quite simple and straightforward. However, behind its simple operating principles lie overwhelming difficulties (causing practicality and cost issues) which is why they have not yet become an integral part of the energy chain.

PEM fuel cells are composed of three major components: the anode bipolar plate containing the anode flow channel, cathode bipolar plate containing the cathode flow channel and a membrane electrode assembly (MEA). The MEA is composed of five parts: anode electrode, anode catalyst layer, electrolyte membrane, cathode catalyst layer and cathode electrode. The electrode is also referred to as the gas diffusion layer (GDL). Figure 1.1 illustrates the structure and composition of a typical single unit PEM fuel cell. 


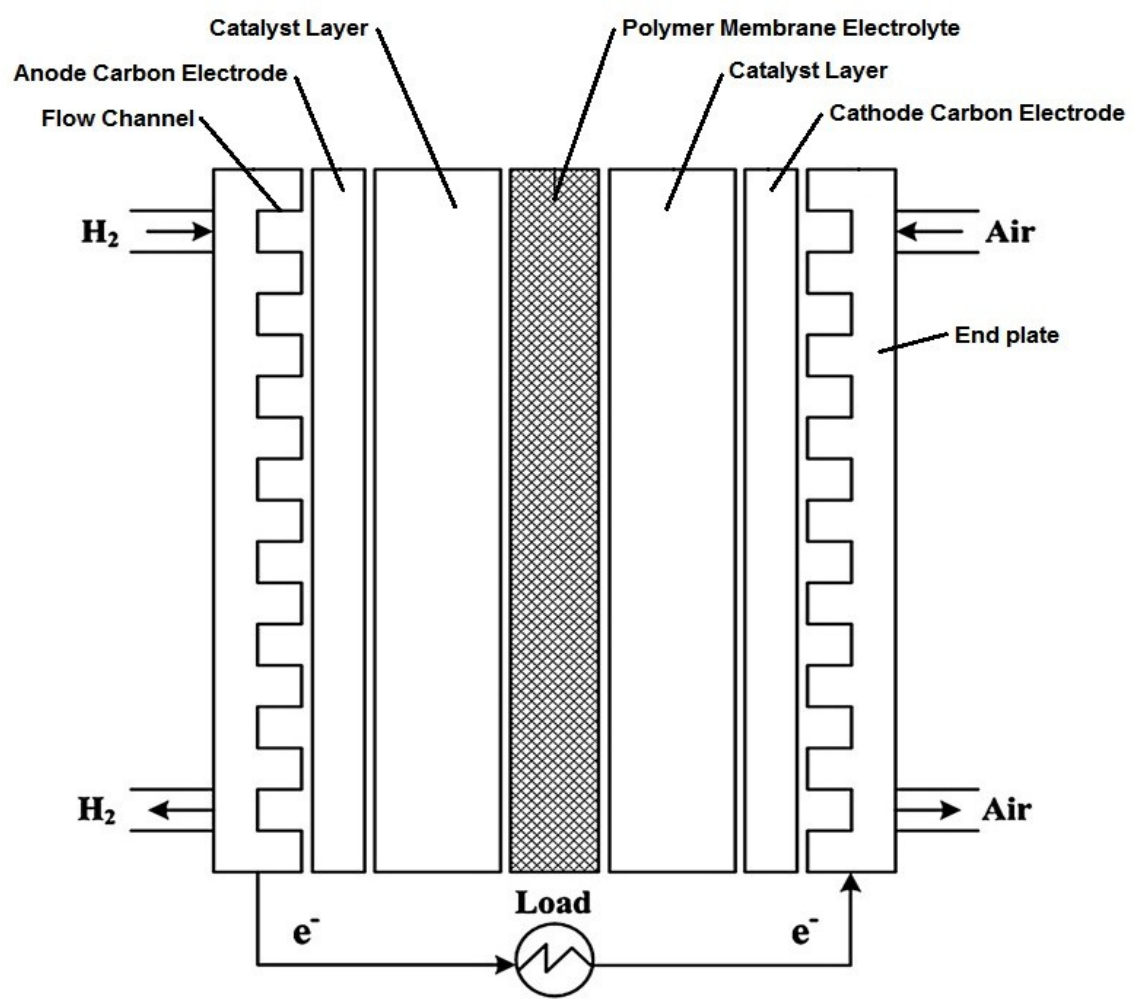

Figure 1.1 - Typical components of a single PEM fuel cell unit.

Hydrogen gas is supplied at the anode into the bipolar plate. It then diffuses through the anode GDL to the anode catalyst layer as it travels through the serpentine flow channel, a feature of the bipolar plate. The reaction, known as the hydrogen oxidation reaction (HOR), where hydrogen is split into electrons and protons is as follows:

$$
\mathrm{H}_{2} \rightarrow 2 \mathrm{H}^{+}+2 \mathrm{e}^{-}
$$

The electrons are forced to travel through an external electric circuit while the protons travel through the electrolyte membrane to the cathode (where oxygen or air is supplied similarly through a serpentine flow channel in the bipolar plate). The oxidant at the cathode diffuses through the GDL to the cathode catalyst layer where it combines with the electrons and protons from the HOR to produce water. This reaction is known as the oxygen oxidation reaction (OOR) which is given by: 


$$
1 / 2 \mathrm{O}_{2}+2 \mathrm{H}^{+}+2 \mathrm{e}^{-} \rightarrow \mathrm{H}_{2} \mathrm{O}
$$

The electrolyte membrane is placed between the anode and cathode to separate the reactants and to prevent their crossover from the anode to the cathode. It is also needed to act as an ion conductor and as an electron insulator. (1.0) and (1.1) are referred to as half-cell reactions, and the summation of the two yields the overall cell reaction of a fuel cell:

$$
\mathrm{H}_{2}+1 / 2 \mathrm{O}_{2} \rightarrow \mathrm{H}_{2} \mathrm{O}+\text { Heat }+ \text { Electricity }
$$

Fuel cells are sensitive to many operating parameters such as temperature, pressure, and reactant concentrations, which consequently affects the stack's efficiency and performance through mass transport limitations. Transport mechanisms such as oxygen diffusion and water transport through the cathode GDL occur simultaneously during cell operation, and the substantial quantities of literature that is available means that an extensive effort has been exerted by researchers to understand these phenomena.

The commercial success of PEM fuel cells still requires further cost reduction and performance improvement, and one of the approaches tackling these challenges is to increase the operating current densities for the design conditions, typically beyond $2 \mathrm{~A} / \mathrm{cm}^{2}$. However, this is where losses due to mass transport become most significant and understanding of these limitations is required for proper design of the cell for higher performance. Figure 1.2 illustrates a general fuel cell polarization curve with three distinct operating regions. 


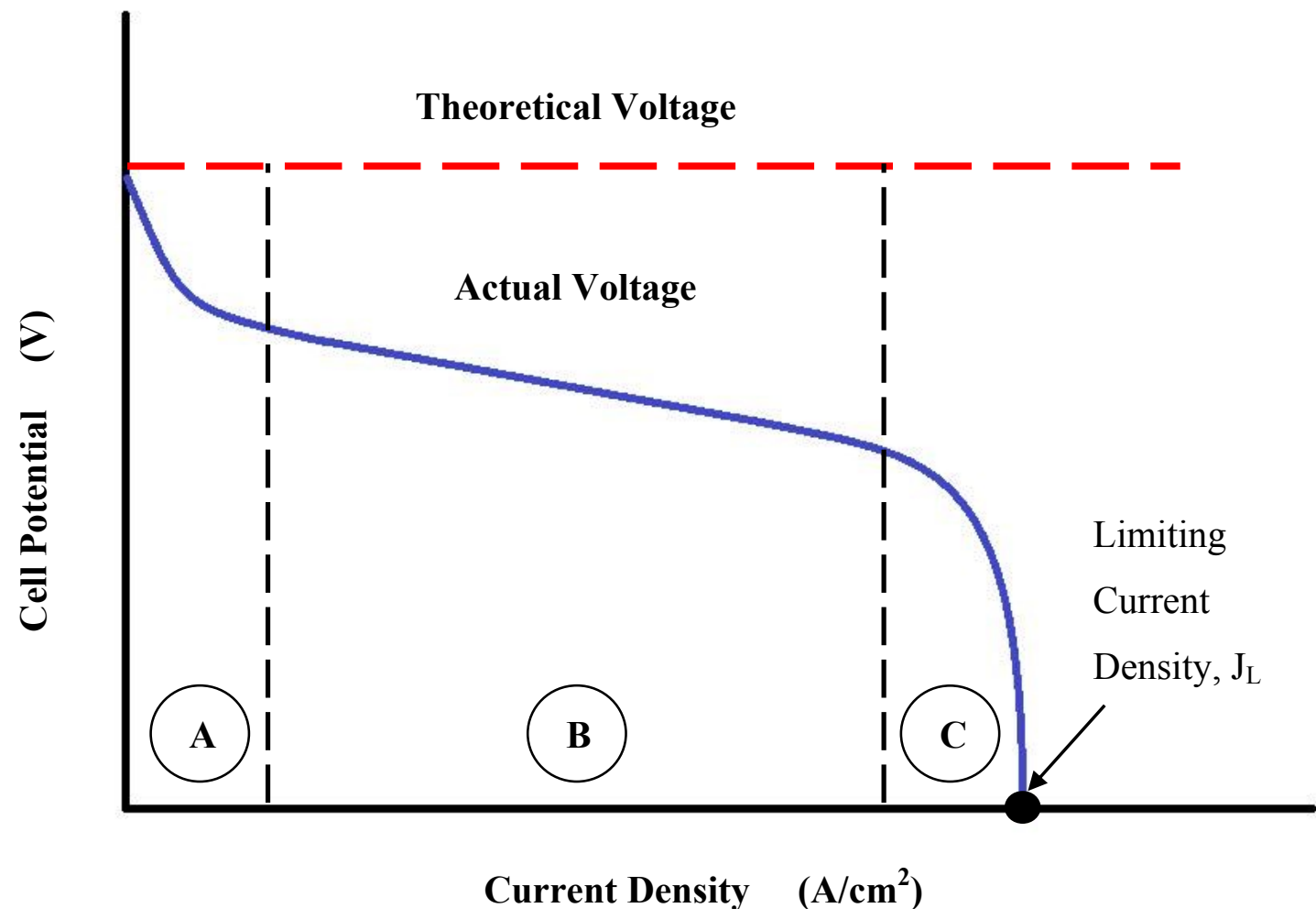

Figure 1.2 - Polarization curve of PEM fuel cell. A: Activation Polarization, B: Ohmic Polarization, and C: Concentration Polarization.

Region A and Region B are known as Activation Polarization and Ohmic Polarization respectively. Region $C$ is the operating range of interest (high current density: $>2 \mathrm{~A} / \mathrm{cm}^{2}$ ) and is known as Concentration Polarization, where the reaction rate is limited by mass transport through the GDL. Most investigations performed in this area are numerical simulations which can vary from studying the performance and optimization of the cell [7-14] to the mass and heat transfer in the cell [15-23]. Experimental research is scarce due to the complexity and difficulty in monitoring the transport mechanisms without interfering with the phenomena, and this raises an issue.

Simulation through numerical modeling is preferred and often used to gain understanding of the transport of gases, electrons, protons, liquid water and heat through the different fuel cell components using the conservation laws (continuity, momentum and 
energy). Though to develop reliable mathematical model for GDL over a broad parameter space, the underlying processes have to be understood through experimental methods and then translated into the right mathematical equations with accurate physical and chemical substance data.

\subsection{Carbon Paper Gas Diffusion Layer}

The GDL is a multi-functional component which provides not only mechanical support to the membrane and catalyst layer but also to the conduction of heat and electricity of the fuel cell. More importantly though, is its role to evenly distribute the reactants to the reaction sites and to provide water management $[24,25]$. This explains the use of porous material in the design of the GDL; the void area provides a region for the free diffusion of gaseous species and the removal of the reaction products, while the solid is used as a transport medium for the electrons to and from the reaction site.

Carbon paper and carbon cloth are the most commonly used materials for the construction of GDL, see Figure 1.3, and there are no indications as to why one is preferred over the other. Both are commercially available and are carbon fiber based porous materials. The two major quantifiable structural differences between these materials are a) carbon cloth is more porous and organized than carbon paper and b) liquid water coverage on carbon cloth is less than that on carbon paper [26]. Consequently, better water transport in carbon-cloth GDL over carbon-paper GDL under humidified conditions can be expected [27]. 

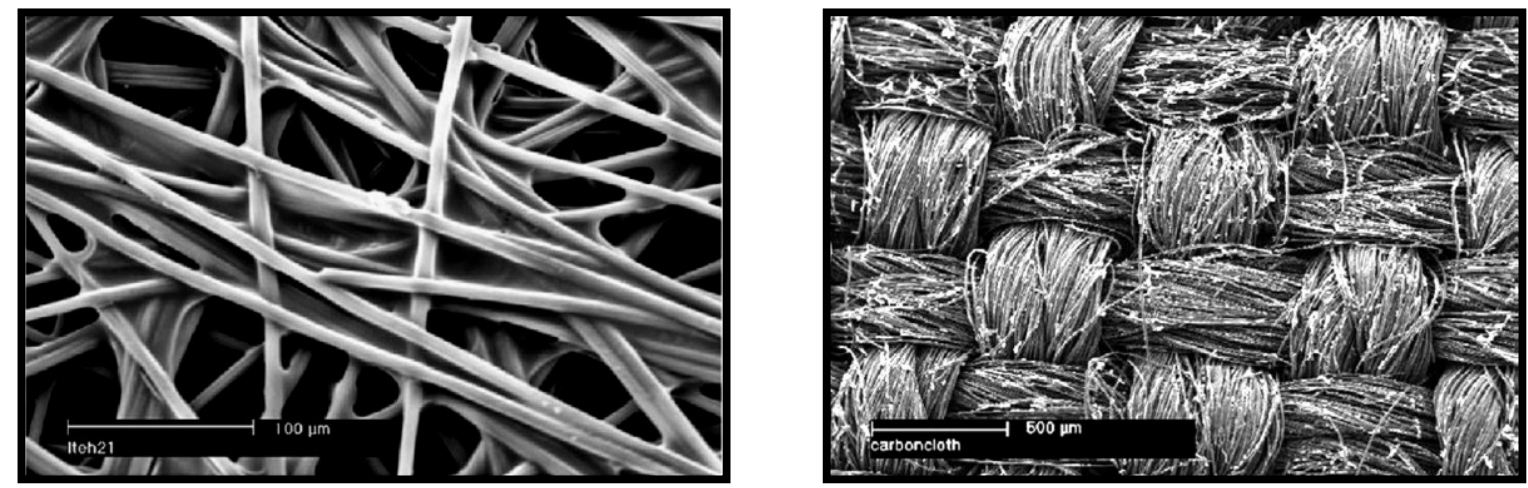

Figure 1.3 - Images of carbon paper (left) and carbon cloth (right) from Scanning Electron Microscope (SEM) [26].

Many features of GDL can be controlled during its manufacturing to obtain desired properties. However, the proper selection is important because thickness, porosity, pore size distribution, addition of microporous layer (MPL), and degree of hydrophobicity will affect mass transport and consequently fuel cell performance. External factors such as compression of the fuel cell during its assembly would also yield similar effects due to induced stresses on the GDL.

The thickness of GDL is a parameter which requires careful balance because an improvement of one property would negatively influence another. A thin GDL may improve gas and water transport but would have poor electrical conductivity. It also allows permeation of the catalyst layer thus reducing the ionic contact with the Nafion membrane [28].

Porosity (or bulk porosity) of GDL is defined as its total pore volume divided by the summation of its total pore volume and its solid volume [29]. Performance loss due to mass transport limitations through the GDL can be reduced by enlarging the macropore volume (increasing porosity); however, the pore-size distribution is a more critical parameter than the total porosity itself [30]. In terms of water management, a large gradient of porosity is more favourable for the discharge of liquid water from the catalyst layer to gas channel [31]. For this reason, it is common to see the addition of an MPL coating on GDL - to increase the pore gradient - as to improve oxygen diffusion kinetics and water management effectiveness 
[25, 32-35]. It has been reported though that with decreasing pore size and porosity of MPL, and an increase in hydrophobicity and thickness of the GDL, the back flow of liquid water would increase [36].

The MPL is a powdery mixture of carbon black and PTFE particles that is often applied to one side of the GDL substrate facing the catalyst layer. It is known to be beneficial for fuel cell performance especially at high current conditions [37] by creating better electrical and thermal contact between the catalyst layer and the GDL. It is also believed that at these demanding conditions, MPL improves the water management inside the fuel cell to allow for better gas transport [38-40].

To facilitate liquid water removal, controlled amounts of Polytetrafluoroethylene (PTFE) is added to the GDL to achieve a level of hydrophobicity. Flooding diminishes cell performance as liquid water covers the active catalyst area and blocks pores; preventing the reactants from reaching the reaction sites and decreasing oxygen transport respectively. PTFE loading is found to be desirable when a cell operates under flooding condition by enhancing water transport and improving oxygen diffusion kinetics [41-45], but excessive loading of the GDL may cause flooding of the catalyst layer [41], a decrease in porosity and permeability, and an increase in its tortuosity and electrical resistance [46].

Compression of the cell and subsequently the GDL generally yields poor cell performance and low durability $[47,48]$ due to the high stresses which may break fibers $(>1.61 \mathrm{MPa})$ and deteriorate hydrophobic coatings [49], and deform - thus increasing porosity variation [50,51] or create preferential pathways for water transport [52]. However, with increased compression, contact resistance decreases thus reducing the Ohmic overpotential (refer back to polarization curve Figure 1.2) [50] and increases thermal conductivity due to the larger contact areas between fibers and to adjacent materials [53-55]. It should be noted though that compression pressure exerted onto the GDL inside a fuel cell assembly is a difficult function to correlate. There is an argument [56] that compression pressure should be represented as compressed thickness instead because the surrounding gasket material thickness dictates the compression of the GDL in a fuel cell assembly. This is 
important to consider because the lands and channels of the bipolar plates causes nonuniformity of pressure distribution on the GDL, not to forget the effects due to variation in manufactured thickness of the GDL as well [54].

Since the GDL has a porous nature, reconstruction of the real geometry for simulation is a complex task and transport coefficients applied in numerical analysis must be adjusted to compensate for geometric characteristics. GDL properties can vary widely as briefly discussed above and each parameter influences species (mass) transport inside the fuel cell to

a different extent. The adjusted coefficients are known as effective transport coefficients and many modeling studies have been performed but very few experimental observations have been made. Some of the data are available in reference books [57] or can be estimated from generally applicable formulas, but the effective diffusion coefficient should be determined experimentally - to provide realistic starting values for new numerical models and/or to check for close agreement with existing models.

\subsection{Objectives and Scope}

The goal of the effort performed by the author is to provide technical contributions for a better understanding of mass transport limitations in the porous layers (GDL/MPL) thus allowing design improvements for achieving higher performance in PEM fuel cells. The objective of the present work is to measure the effective diffusion coefficients through PEM fuel cell GDLs without and with the MPL, and to determine the effect of MPL coating on the effective diffusion coefficient.

A literature review of the currently available correlations and experimental data regarding effective diffusion coefficients in porous media and GDL will be conducted in Chapter 2. In Chapter 3, the measurement principles will be described and the equations that will be used in the result analysis will be introduced. In Chapter 4, a detailed explanation is provided for the apparatus design, operating procedure and calibration. In Chapter 5, results are presented followed by a discussion in Chapter 6 . 


\section{Chapter 2}

\section{Literature Review}

Diffusion is caused by the random movement (Brownian motion) of atoms or molecules, from a region of higher concentration to one of lower concentration that leads to complete mixing. This is an atomic-scale motion which is fairly rapid in gases - a rate in the order of $\mathrm{cm} / \mathrm{s}$ - slow in liquids but observable - fractions of $\mathrm{mm} / \mathrm{s}$ - and is almost impossible to observe in solids even though diffusion in solids does occur. It is a fairly slow process and the rate of diffusion decreases strongly with decreasing temperature.

The study of diffusion coefficients has an extensive history and presents great importance to a wide variety of industrial applications. Some of the major milestones of diffusion as a scientific discipline dates back to the $19^{\text {th }}$ century. The continuum theory of diffusion originates from the work of the Adolf Eugen Fick (1829 - 1901), a physiologist who was inspired by the experiments on diffusion in gases and of salt in water performed by Thomas Graham (1805 - 1869). Graham initiated the quantitative study of diffusion in gases from 1828 to 1833 and he recognized that gases of different nature, when brought into contact, do not arrange themselves according to their density with the heaviest undermost. Instead they diffuse through each other and finally achieve an intimate state of mixture. Later on, vapour-chemist Johann Joseph Loschmidt (1821 - 1895) used an experimental device similar to that of Graham for his classical measurements of diffusion in several gas pairs [58].

A diffusion coefficient $\left(\mathrm{cm}^{2} / \mathrm{s}\right)$ is a measure of the diffusivity of one species into the other. For gaseous species, a binary mixture is most often used for analysis (i.e. the diffusion of species $i$ into species $j$ ). The most common diffusion coefficients are bulk diffusion coefficients, $D_{i j}$ or $D_{\text {bulk, }}$, which is the measure of the diffusion between species $i$ and species $j$ without the interference by any objects, but realistically they are obstructed by porous materials. Sandstone, soil, various catalysts, composites, sintered glass and other natural and man-made porous materials lower the bulk diffusion coefficient and this effect is accounted 
for by the effective diffusion coefficient, $D_{\text {eff }}$. The bulk diffusion coefficient is hindered in porous material due to the lower fraction of void space, which reduces the available area for diffusion. It is expected to affect the effective diffusion coefficient, $D_{\text {eff }}$, according to the following equation

$$
D_{\text {eff }}=D_{\text {bulk }} \frac{\varepsilon}{\tau}
$$

where $\varepsilon$ is the porosity, $\tau$ is the tortuosity, and $D_{\text {bulk }}$ is the bulk diffusion coefficient.

Commercially useful practices include gas injection into oil reservoirs to enhance hydrocarbon recovery in the oil industry. More recently, $\mathrm{CO}_{2}$ geological sequestration has been considered a promising option to mitigate the drastic increase in $\mathrm{CO}_{2}$ concentrations in the atmosphere. Both $\mathrm{CO}_{2}$-EOR (enhanced oil recovery) and $\mathrm{CO}_{2}$ geological sequestration require reliable data of the $D_{\text {eff }}$ for project design, risk assessment, economic evaluation and performance forecast [59].

For managing emissions for the combustion of diesel in vehicles, the development of diesel particulate filters (DPF) with catalytic coatings and integrated soot filtration mechanisms have been employed for the oxidation of $\mathrm{CO}$, hydrocarbons, and $\mathrm{NO}_{\mathrm{x}}$ from diesel exhaust gas. The $D_{\text {eff }}$ for studying catalytically active filter devices, such as those used in diesel exhaust gas systems, are also important for the set-up of numerical models and for the design of improved coating procedures [60].

The examples presented above should give a good idea of the importance that the $D_{\text {eff }}$ has in various industries, not to forget the PEM fuel cell. Oxygen gas at the cathode of a fuel cell must diffuse through the porous structure of carbon-fiber based GDL to reach the catalyst layer such that the electrochemical reaction can occur. The $D_{\text {eff }}$ of GDL is a parameter which gives understanding to the mass transport limitations of the fuel cell at high current densities. Analysis through theoretical and empirical relations of effective transport properties through a wide range of porous medium can be found in literature, but those for GDLs in PEM fuel cells are lacking - especially experimental data. 
The empirical relations that can be found use porosity as an independent variable, coupled with a correction factor. Relationships have been proposed as summarized in Table 2.1 for porous materials (Das et al. 2009 [61]; Mezedur et al. 2002 [62]; Nam and Kaviany 2003 [63]; Tomadakis and Sotirchos 1993 [64]) porous solid particle materials (Maxwell 1954 [65]; Rayleigh 1892 [66]; Weissberg 1963 [67]; Neale and Nader 1973 [68]; Bruggeman 1935 [69]) and GDL (Zamel et al. 2009 [70]) and they are used for calculating gas diffusion based on Fick's law. However, some of these approximations are inadequate for calculating the dependence of diffusibility on the internal microstructure including porosity, pore shape, pore size distribution and pore connectivity [71]. Diffusibility, $Q$, is defined as:

$$
Q=\frac{D_{\text {eff }}}{D_{\text {bulk }}}
$$


Table 2.1 - Summary of conventional correlations and numerical models available to determine the effective diffusion coefficient of porous media.

\begin{tabular}{|l|l|l|}
\hline \multicolumn{1}{|c|}{ Reference } & \multicolumn{1}{|c|}{ Model } & \multicolumn{1}{c|}{ Type } \\
\hline $\begin{array}{l}\text { Bruggeman } \\
{[69]}\end{array}$ & $D_{\text {eff }}=\varepsilon^{1.5} D_{\text {bulk }}$ & $\begin{array}{l}\text { Effective medium } \\
\text { approximation }\end{array}$ \\
\hline $\begin{array}{l}\text { Neale and } \\
\text { Nader [68] }\end{array}$ & $D_{\text {eff }}=\left(\frac{2 \varepsilon}{3-\varepsilon}\right) D_{\text {bulk }}$ & $\begin{array}{l}\text { Effective medium } \\
\text { approximation }\end{array}$ \\
\hline $\begin{array}{l}\text { Tomadakis } \\
\text { and Sotirchos } \\
{[64]}\end{array}$ & $D_{\text {eff }}=\varepsilon\left(\frac{\varepsilon-0.037}{1-0.037}\right)^{0.661} D_{\text {bulk }}$ & $\begin{array}{l}\text { Percolation } \\
\text { theory }\end{array}$ \\
\hline $\begin{array}{l}\text { Nam and } \\
\text { Kaviany [63] }\end{array}$ & $D_{\text {eff }}=\varepsilon\left(\frac{\varepsilon-0.11}{1-0.11}\right)^{0.785} D_{\text {bulk }}$ & $\begin{array}{l}\text { Percolation } \\
\text { theory }\end{array}$ \\
\hline $\begin{array}{l}\text { Das et al. } \\
{[62]}\end{array}$ & $D_{\text {eff }}=\left\{1-\left[\frac{3(1-\varepsilon)}{3-\varepsilon}\right]\right\} D_{\text {bulk }}$ & $\begin{array}{l}\text { Effective medium } \\
\text { approximation }\end{array}$ \\
\hline $\begin{array}{l}\text { Zamel et al. } \\
{[70]}\end{array}$ & $D_{\text {eff }}=\left\{1-2.76 \varepsilon \cosh (3 \varepsilon-1.92)\left[\frac{3(1-\varepsilon)}{3-\varepsilon}\right]\right\} D_{b u l k}$ & $\begin{array}{l}\text { Stochastic model } \\
\text { based }\end{array}$ \\
\hline
\end{tabular}

The use of accurate transport coefficients to simulate the mass transport at high current densities in PEM fuel cells is required, and the research undertaken by the author looks into the experimental methods that could be used to determine the $D_{\text {eff }}$ of GDL and to design and use such apparatus to perform measurements on such samples. Conventional correlations can significantly over-predict the $D_{\text {eff }}$ by as much as 4-5 times [72] as shown in Figure 2.1; thus underestimating the transport limitations of PEM fuel cells. 


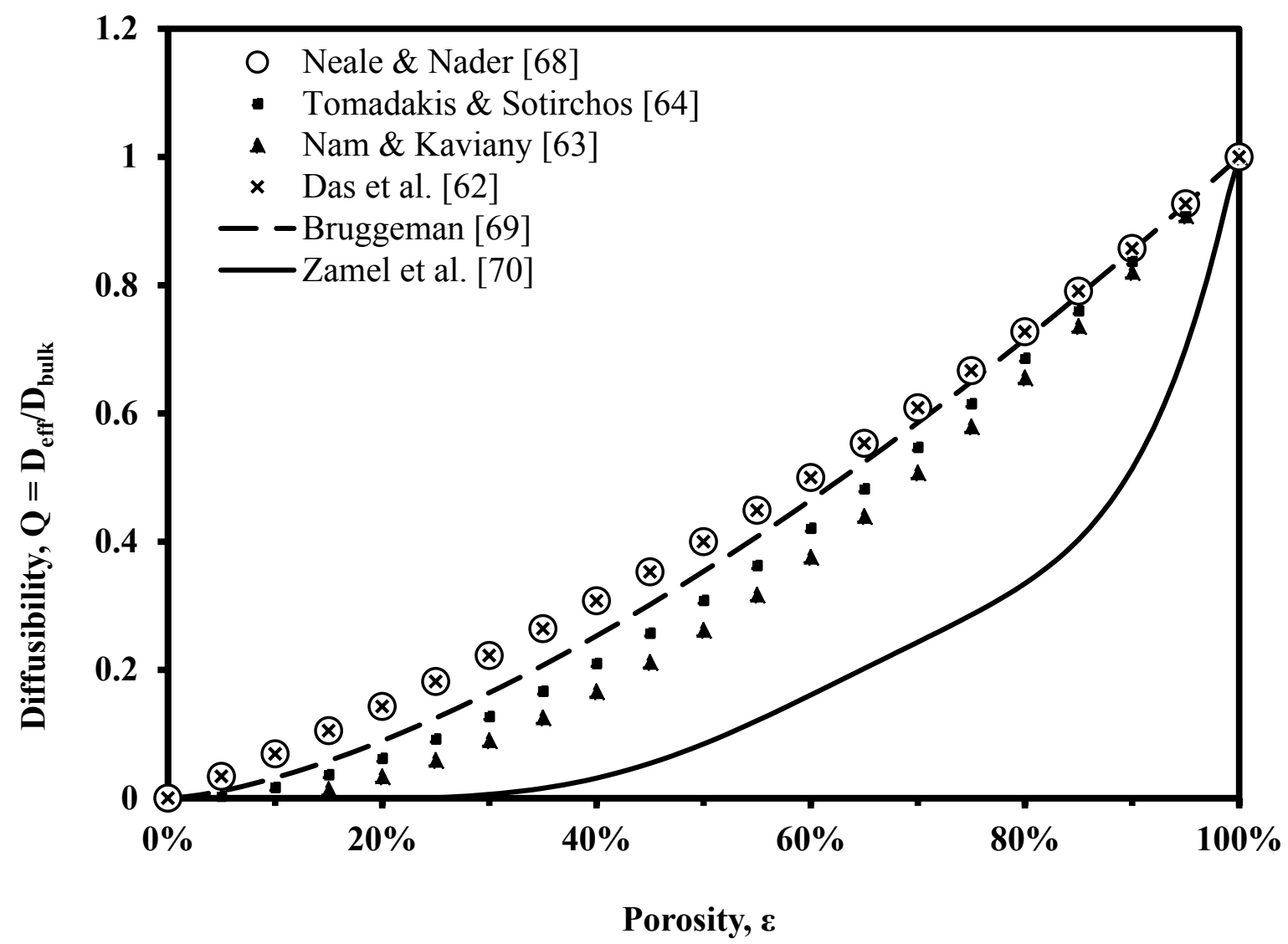

Figure 2.1 - Comparison of conventional correlations and Zamel et al.'s [70] model for the diffusibility of porous media. It can be seen that conventional correlations tend to over-predict mass transport.

\subsection{Experimental Techniques}

A few known experimental attempts to investigate the $D_{\text {eff }}$ in the GDL can be found in literature from in-situ to ex-situ measurements. Baker et al. [73], Beuscher [74] and Stumper et al. [75] obtained the $D_{\text {eff }}$ of GDL using the limiting current density measurements (in-situ measurements).

Limiting current density, $J_{L}$, is referred to as the maximum current density achieved when the oxygen concentration approaches zero at the electrochemical active surface (typically the catalyst and gas diffusion layer). $J_{L}$ is found on the polarization curve (Figure 
1.2) at the intersection between the actual cell potential and the x-axis (current density). At this state, the current density becomes independent of overpotential. The use of limiting current density to characterize the gas transport resistance in PEM fuel cells is associated with difficulties such as cell compression effects and convective transport in the flow field [76]. Also, this method provides only an average quantity since it is not possible to distinguish between the in-plane and through-plane direction. It is known that GDL is highly anisotropic [77] as illustrated in Figure 2.2.
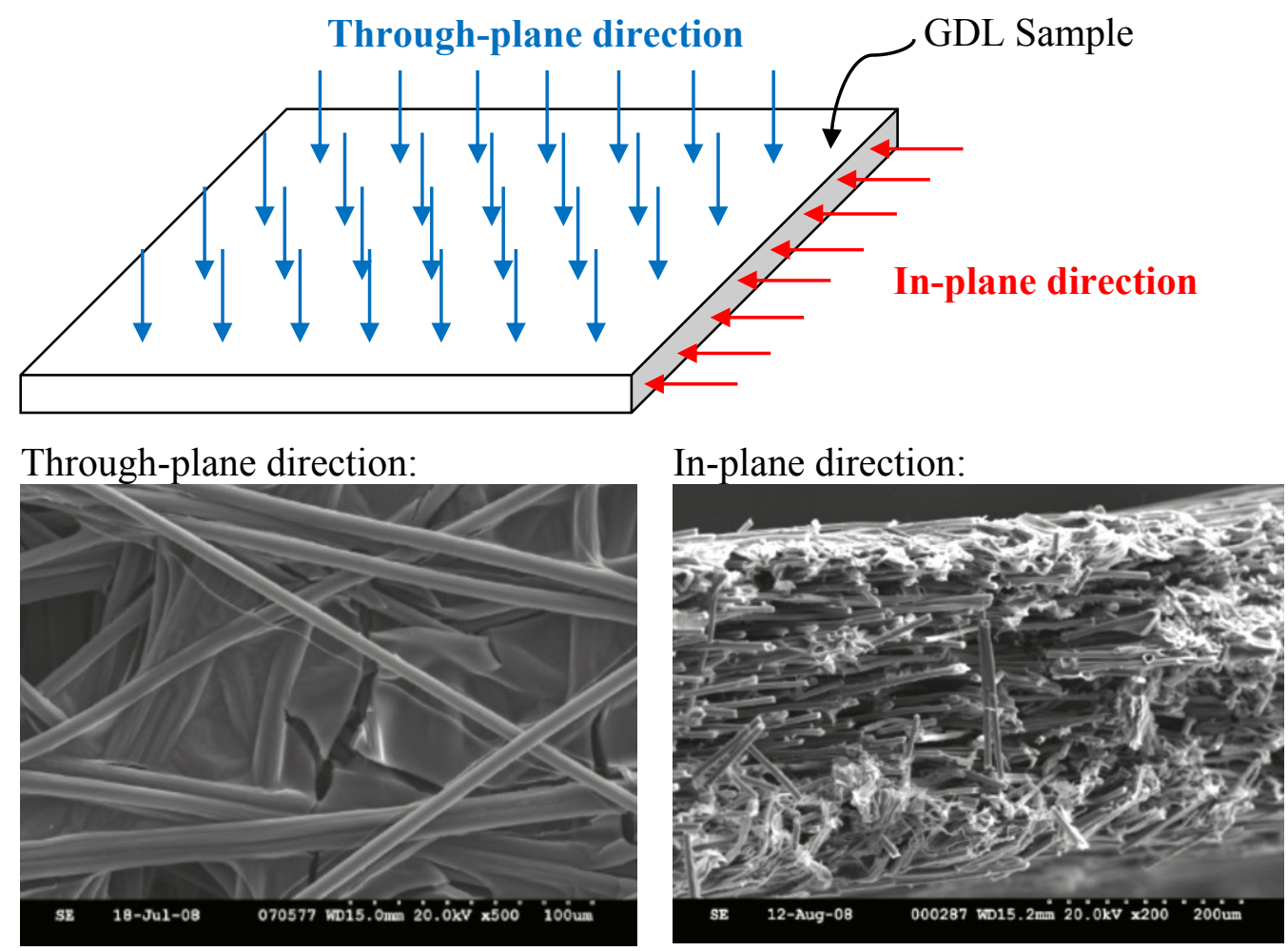

Figure 2.2 - The through-plane and in-plane directions of the GDL are shown schematically and the SEM images [70] of each section illustrate its anisotropic structure.

In terms of ex-situ measurements, Baker et al. [73] also determined the $D_{\text {eff }}$ of diffusion medium/microporous layer in a water vapour in air mixture. Kramer et al. [76] and 
Flückiger et al. [78] noticed the short comings with the limiting current density approach and used electrochemical diffusimetry by applying similarities between Fick's law and Ohm's Law to estimate the $D_{\text {eff }}$ of GDL. The effects of GDL substrate, PTFE content, anisotropy, and compression on the through-plane and in-plane $D_{\text {eff }}$ were studied. Impedance spectroscopy was used to measure the effective ionic conductivity of an electrolyte-soaked GDL. During an impedance measurement, a frequency response analyzer (FRA) was used to impose a small amplitude AC signal and the AC voltage and current response is analyzed by the FRA to determine the impedance at that particular frequency. Physico-chemical processes occurring within the cell have different characteristic time-constants and therefore are exhibited at different $\mathrm{AC}$ frequencies. Figure 2.3 illustrates the experimental apparatus used by Kramer and Flückiger.
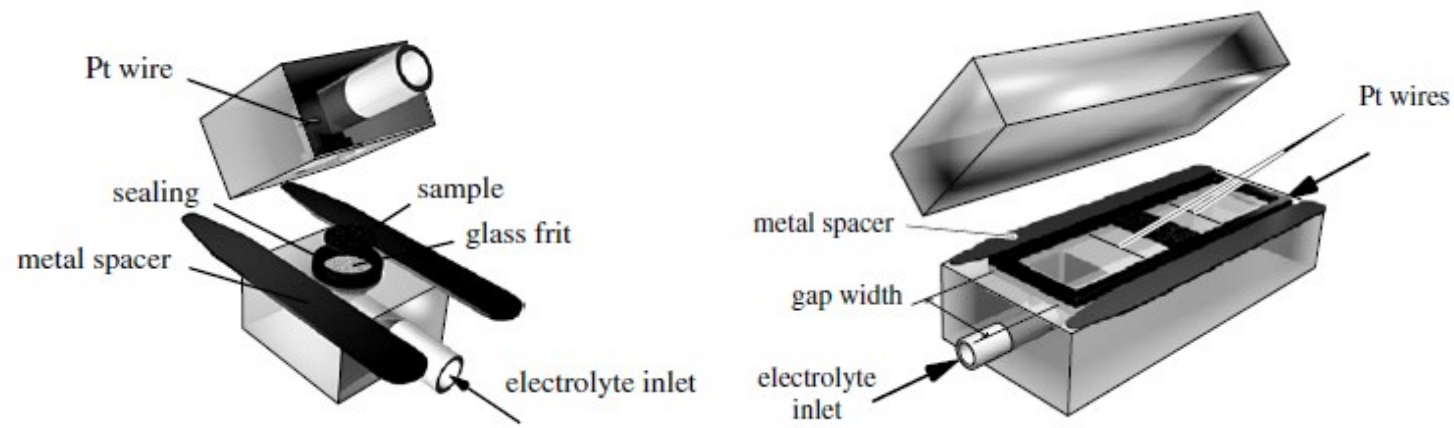

Figure 2.3 - Electrochemical diffusimetry experimental apparatus used by Kramer et al. [77] and Flückiger et al. [78] Left: Through plane, Right: In-plane.

Zamel et al. [72] and Astrath et al. [79] performed experiments in an oxygen-nitrogen mixture using a modified Loschmidt cell with a fiber-optic oxygen sensor. The effects of temperature, Teflon treatment and porosity were investigated. The Loschmidt cell is also known as the closed-tube method and determinations of bulk diffusion coefficients by this method are usually quite reliable [80]. It consists of a top and bottom chamber filled with pure nitrogen gas and pure oxygen gas respectively (Figure 2.4). In the chamber filled with nitrogen, a fiber-optic oxygen sensor was placed to record the concentration of oxygen as the two gases diffuse through a GDL sample - placed between the two chambers. 


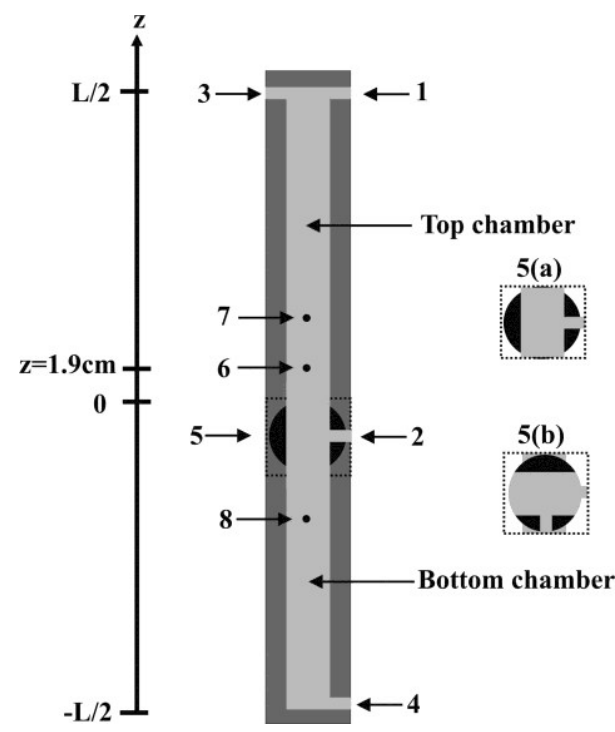

Figure 2.4 - Modified Loschmidt cell used by Zamel et al. [72] and Astrath et al. [79].

Quick et al. [81] used a modified horizontally oriented fuel cell shown in Figure 2.5 to perform ex-situ water transport measurements. The GDL separates a saturated phase with liquid water ('water side') from a gas phase ('gas side') and the water transport rate through the diffusion media was determined as function of the air flow at the 'gas side'. The assumption was made that differences in the water removal properties are due to different crucial properties of the investigated GDLs and the membrane was always fully saturated with liquid water. The water loss in the reservoir feeding the flow channel was recorded and corresponded to the amount of water removed at the 'gas side' of the cell. The effects of substrate, impregnation mixture, PTFE content, and MPL coating on water transport through the GDL were studied. 


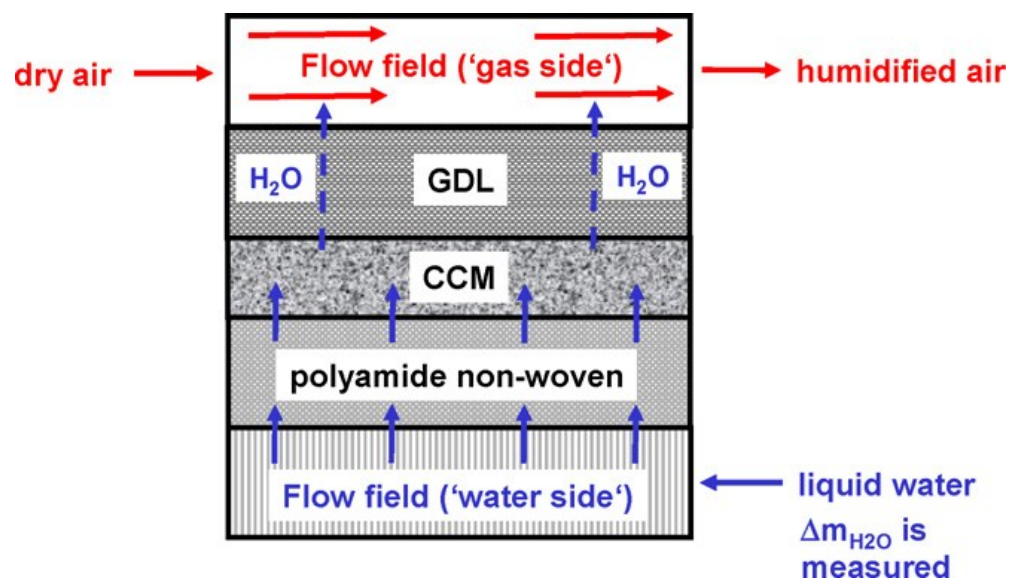

Figure 2.5 - Modified fuel cell used by Quick et al. [81] with a hydrophilic polyamide non-woven which soaked up the liquid water from the "water side" flow channel to transfer through the catalyst-coated membrane and gas diffusion layer to exit at the "gas side" flow channel.

Casalegno et al. [82] investigated the effects of MPL on water management by supplying GDL faces with a humid air flow and a dry air flow, respectively, in a co-current configuration as represented in Figure 2.6. Water transfer takes place across the porous medium from the humid to dry side and water concentrations and volumetric flows were obtained during the experiment.

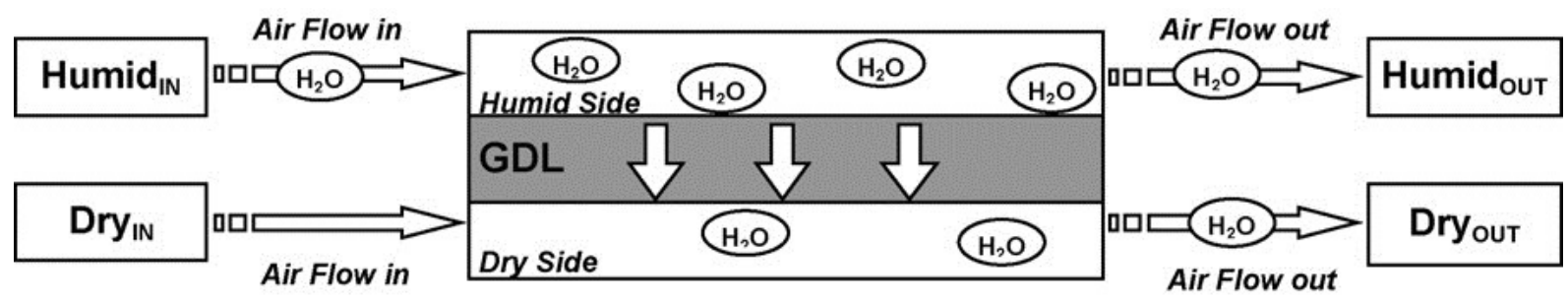

Figure 2.6 - Casalegno et al. [82] used a single straight channel with co-current dry and humid air flow.

LaManna et al. [83] used a dynamic cell with single straight channels to determine the effects of MPL coatings, GDL thickness, and PTFE loading on the $D_{\text {eff }}$ of water vapour. Figure 2.7 shows the schematic of the parallel flow mass exchanger utilized. The water 
vapour concentration gradients are controlled by manipulating the relative humidity in the flow streams on either side of the GDL.

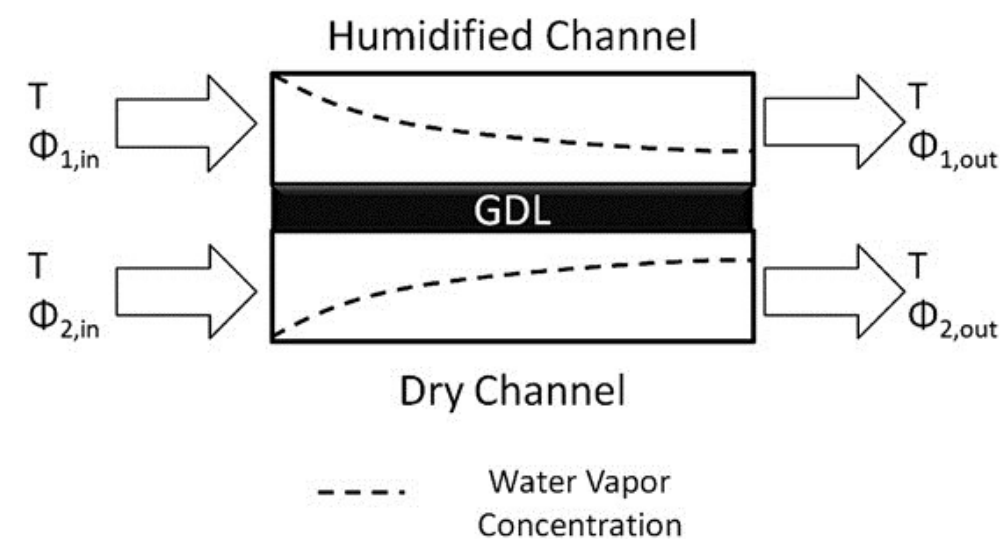

Figure 2.7 - LaManna et al. [83] used a single straight channel with two parallel humidified air streams.

The work performed by the efforts of these authors give insight into the effects of GDL substrate, PTFE content, anisotropy, compression, temperature, and MPL coating on the $D_{\text {eff. }}$ All of these studies were limited to pure GDLs, and experimental analysis of the impact of the MPL on the overall diffusion in the porous GDL is still lacking. When considering the MPL coating, Fick's law is insufficient in approximating the mass diffusion process due to its very fine pore sizes. For a pore diameter less than $1 \mu \mathrm{m}$, it is essential to account for the effect of Knudsen diffusion on the effective diffusion coefficient [71].

In this study, a modified Loschmidt cell similar to Zamel et al. [72] and Astrath et al. [79] is constructed to perform the measurements. The experimental measurements reported in this study are conducted with an oxygen-nitrogen mixture at room conditions such that comparisons can be made with data available in literature. 


\section{Chapter 3}

\section{Principle of Measurement}

\subsection{For a Single Porous Layer}

In order to measure the effective diffusion coefficient through a porous material, such as the GDL or GDL with MPL in PEM fuel cells, consider a gas species $i$ shown in Figure 3.1, a representative of the so-called Loschmidt cell for diffusion measurement. The species $i$ is located in the lower half of the infinitely long cylinder, diffusing through a thin layer of a porous material located in the upper half of the cylinder containing species $j$. The upper half of the cylinder is initially devoid of species $i$.

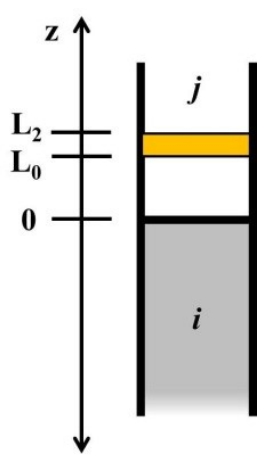

Figure 3.1 - Illustration of infinitely long cylinder used for derivation of general diffusion equation for short periods of time.

The diffusion process in the Loschmidt cell follows the one-dimensional Fick's law of diffusion and is governed by the following equation

$$
\frac{\partial C_{i}}{\partial t}=D_{i}^{\mathrm{eq}} \frac{\partial^{2} C_{i}}{\partial z^{2}}
$$

subject to the following conditions:

$$
C_{i}=\left\{\begin{array}{c}
C_{i}^{b} \text { for }\left(-\infty<z<0, t=t_{0}\right) \\
0 \text { for }\left(0<z<+\infty, t=t_{0}\right)
\end{array}\right.
$$


where $C_{i}$ is the concentration of species $i, D_{i}^{\mathrm{eq}}$ is the equivalent diffusion coefficient of species $i, z$ is the spatial dimension and $t$ is the time. The solution to this one-dimensional diffusion process for short diffusion time was given by Crank [84] as

$$
C_{i}=\frac{C_{i}^{b}}{2} \operatorname{erfc}\left(\frac{H}{2 \sqrt{\left(t-t_{0}\right) D_{i}^{\mathrm{eq}}}}\right)
$$

where $C_{i}^{b}$ is the initial concentration of species $i$ in the bottom chamber, $\mathrm{H}$ is the location of the concentration sensor in the z-direction from the zero axis, and $t_{0}$ is the time at which diffusion commences.

The concentration of the species $i$ at any location $\mathrm{z}>0$ is schematically shown in Figure 3.2. The measured curve represents the concentration, $C_{i}$ that would be measured by a concentration sensor in the upper half of the cylinder at location $z=H$. Curve fitting this measured concentration history by Eq. (3.3) will yield the equivalent diffusion coefficient, $D_{i}^{\mathrm{eq}}$. 


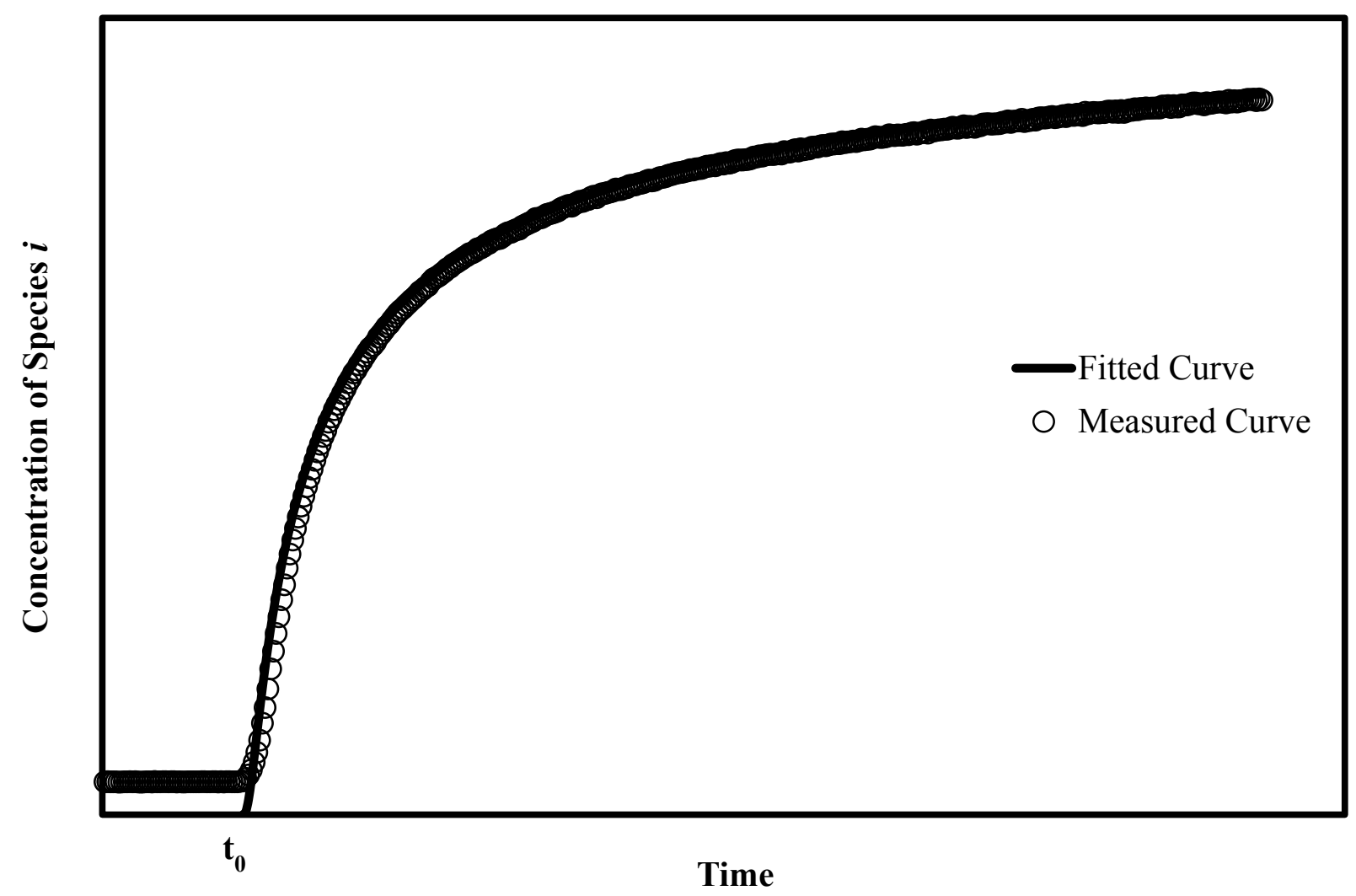

Figure 3.2 - Illustration of the measured species concentration and curve fitting by Eq. (3.3) in determining the equivalent diffusion coefficient.

After obtaining $D_{i}^{\mathrm{eq}}$, the resistance network shown in Figure 3.3 is used to determine the effective diffusion coefficient through the thin porous layer, $D_{i}^{\text {eff, } 1}$, located at $\mathrm{z}=\mathrm{L}_{0}$. 


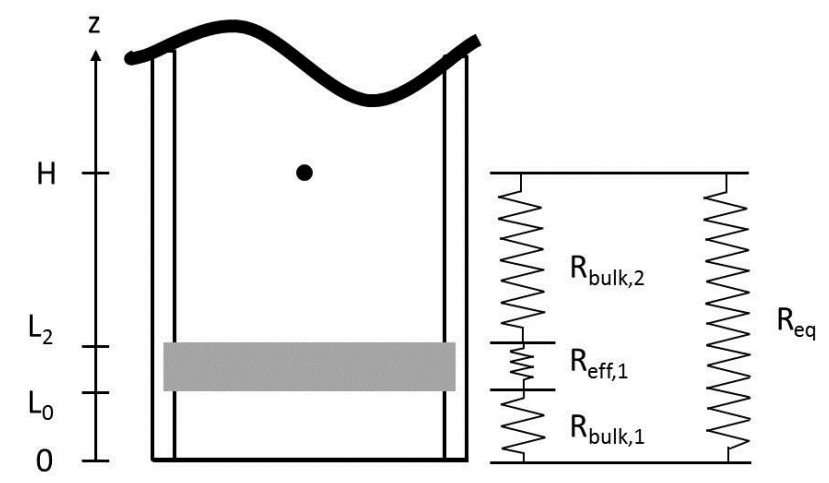

Figure 3.3 - Resistance network for one thin porous layer.

From the network, it is found that the equivalent resistance, $R_{\mathrm{eq}}$, is due to the diffusion of species $I$ in species $j$ and diffusion in the thin porous layer, which is obtained by

$$
R_{\mathrm{eq}}=\frac{H}{D_{i}^{\mathrm{eq}} A_{c}}
$$

where $\mathrm{H}$ is the location of the concentration sensor and $\mathrm{A}_{\mathrm{c}}$ is the cross-sectional area of the cylinder, which is available for diffusion.

The resistance due to the diffusion of the species $I$ in species $j$ before and after the porous layer is denoted by $R_{\text {bulk,1 }}$ and $R_{\text {bulk,2 }}$ respectively. These resistances can be determined by

$$
R_{\mathrm{bulk}, 1}=\frac{L_{0}}{D_{i}^{\text {bulk }} A_{c}}, \quad R_{\mathrm{bulk}, 2}=\frac{H-L_{2}}{D_{i}^{\text {bulk }} A_{c}}
$$

where $\mathrm{L}_{0}$ is the bottom surface of the porous layer, $\mathrm{L}_{2}$ is the top surface of the porous layer and $D_{i}^{\text {bulk }}$ is the bulk diffusion coefficient (commonly known as $D_{i j}$ ). The bulk diffusion coefficient of different species is available and can be found in reference books, e.g., [80].

Similarly, the resistance due to the diffusion in the porous layer, $R_{\mathrm{eff}, 1}$, is found by

$$
R_{\mathrm{eff}, 1}=\frac{L_{2}-L_{0}}{D_{i}^{\mathrm{eff}, 1} A_{c}}
$$


Combining Eqs. (3.4) - (3.6), the equivalent resistance becomes

$$
R_{\mathrm{eq}}=\frac{H}{D_{i}^{\mathrm{eq}} A_{c}}=\frac{L_{0}}{D_{i}^{\mathrm{bulk}} A_{c}}+\frac{H-L_{2}}{D_{i}^{\mathrm{bulk}} A_{c}}+\frac{L_{2}-L_{0}}{D_{i}^{\text {eff, } 1} A_{c}}
$$

From Eq. (3.7), the effective diffusion coefficient of the thin porous layer, $D_{i}^{\text {eff, } 1}$, can then be obtained as

$$
D_{i}^{\mathrm{eff}, 1}=\frac{L_{2}-L_{0}}{\left(\frac{H}{\left.D_{i}^{\mathrm{eq}}-\frac{H-L_{2}-L_{0}}{D_{i}^{\text {bulk }}}\right)}\right.}
$$

\subsection{For Two Porous Layers}

In the presence of an additional thin porous layer, that is, two thin porous layers in the upper cylinder, the resistance network shown in Figure 3.4 is used to determine the effective diffusion coefficient through the top layer, $D_{i}^{\text {eff,top }}$, located at $\mathrm{z}=\mathrm{L}_{1}$ with the thickness of $\mathrm{L}_{2}-$ $\mathrm{L}_{1}$.

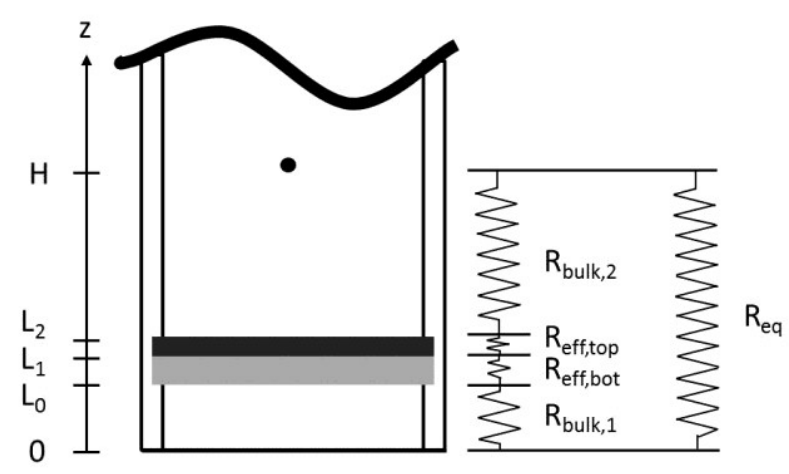

Figure 3.4 - Resistance network for two thin porous layers.

The resistance due to the diffusion in the bottom layer, $R_{\text {eff,bot }}$, and the resistance due to the diffusion in the top layer, $R_{\text {eff,top }}$, is found by

$$
R_{\text {eff,bot }}=\frac{L_{1}-L_{0}}{D_{i}^{\text {eff,bot }} A_{c}}, \quad R_{\text {eff,top }}=\frac{L_{2}-L_{1}}{D_{i}^{\text {eff,top }} A_{c}}
$$


where $\mathrm{L}_{1}$ is the interface between the two layers, and $D_{i}^{\text {eff,bot }}$ and $D_{i}^{\text {eff,top }}$ are the effective diffusion coefficients of the bottom and top layer respectively. Combining Eqs. (3.4), (3.5) and (3.9), the equivalent resistance becomes

$$
R_{\mathrm{eq}}=\frac{H}{D_{i}^{\mathrm{eq}} A_{c}}=\frac{L_{0}}{D_{i}^{\text {bulk }} A_{c}}+\frac{H-L_{2}}{D_{i}^{\text {bulk }} A_{c}}+\frac{L_{1}-L_{0}}{D_{i}^{\text {eff,bot }} A_{c}}+\frac{L_{2}-L_{1}}{D_{i}^{\mathrm{eff}, \mathrm{top}} A_{c}}
$$

From Eq. (3.10), the effective diffusion coefficient of the top layer, $D_{i}^{\text {eff,top }}$, can be obtained as

$$
D_{i}^{\text {eff,top }}=\frac{L_{2}-L_{1}}{\left(\frac{H}{\left.D_{i}^{\text {eq }}-\frac{H-L_{2}-L_{0}}{D_{i}^{\text {bulk }}}-\frac{L_{1}-L_{0}}{D_{i}^{\text {eff,bot }}}\right)}\right.}
$$

\subsection{For Porous Layer of Small Pore Sizes}

Mass transfer can take place by Knudsen flow or ordinary (Fickian) diffusion if the pores are sufficiently small [85]. The regime of diffusion is often characterized by the Knudsen Number, Kn, which is defined as

$$
\mathrm{Kn}=\frac{\lambda}{l_{c}}
$$

where $\lambda$ is the mean molecular free path length and $l_{c}$ is the critical length. In the context of porous media the critical length refers to the pore diameter, $d_{\text {pore }}$. The four flow regimes that can be determined from the Knudsen number are [86]:

$$
\begin{array}{cl}
\mathrm{Kn}<0.001 & \text { the continuum regime: molecule-molecule collisions predominate } \\
\mathrm{Kn}>10 & \text { the Knudsen regime: molecule-wall collisions predominate } \\
0.1<\mathrm{Kn}<10 & \text { the transition regime: both diffusion types occur simultaneously } \\
0.001<\mathrm{Kn}<0.1 & \text { region of slip flow: fluid velocity on the wall differs from wall velocity }
\end{array}
$$

In the continuum region, Fick's law of diffusion is used and the equations presented earlier in this section are developed from this. In the other two regions, $\mathrm{Mu}$ et al. [71] proposed a finite element method for calculating the effective gas diffusion coefficients 
including Knudsen effects. His model discretizes the entire pore space in the porous layer into a number of small tubes with different diameters. The Dusty-gas Model (DGM) [87, 88] and Bosanquet formula [89] are used to estimate the effect of pore size on the effective diffusion coefficient and Knudsen effect. In a single cylindrical pore, the effective diffusion coefficient can by determined by:

$$
\frac{1}{D^{\text {eff }}}=\frac{1}{D_{\text {Fickian }}}+\frac{1}{D_{\text {Kn }}}
$$

where $D_{\text {Fickian }}$ is the Fickian diffusion coefficient and $D_{\mathrm{Kn}}$ is the Knudsen diffusion coefficient $[85,90]$ given by

$$
D_{\mathrm{Kn}}=\frac{4}{3} d_{\text {pore }} \sqrt{\frac{\mathcal{R} T}{2 \pi M_{i}}}
$$

where $d_{\text {pore }}$ is in $[\mathrm{m}], \mathcal{R}$ is the gas constant $\left[\mathrm{J}^{*} \mathrm{kmol}^{-1} * \mathrm{~K}^{-1}\right], T$ is in $[\mathrm{K}]$, and $M_{i}$ is the molecular weight $\left[\mathrm{kg}^{*} \mathrm{kmol}^{-1}\right]$. 


\section{Chapter 4}

\section{Method Selection and Apparatus Design}

Based on the theoretical foundation described in the previous section, a modified Loschmidt cell consisting of two chambers is developed as the experimental apparatus in this study as shown in Figure 4.1. The cell design was based on the one developed at NRCInstitute for Fuel Cell Innovation (IFCI) $[79,91]$ where the diffusion process is confirmed to follow the one-dimensional Fick's law of diffusion for short diffusion time [91, 92]. Similarly, the same diffusion medium, oxygen-nitrogen gas pair (species $I$ and $j$ respectively) is used in this work.

The modified Loschmidt cell consists of a top and bottom chamber, each with an interior length and diameter of $177.5 \mathrm{~mm}$ and $20.6 \mathrm{~mm}$, respectively. The main difference in design of this replica is the connectivity of the chambers, which is separated by a $2 \mathrm{~mm}$ thick sliding gate valve and is considered a part of the bottom chamber as shown in Figure 4.1. The position of the valve is controlled by a stepper motor which can connect the chambers, position (6a), or separate them, position (6b). The upper side of the sliding gate valve marks the middle of the diffusion cell and is represented as $\mathrm{z}=0$ on the coordinate system. A removable sample holder (10) is installed in the top chamber to secure GDL samples in a through-plane orientation. Two mass flow controllers (Omega, Model FMA-5508) with a flow capacity of $0-100 \mathrm{~mL} / \mathrm{min}$, are connected to the inlets ( 1 and 4 ) to control the mass flow rate of the gases filling the chambers. Outlets (2), (3) and (5) allow the rejection of gases inside the chamber to room pressure. A $300 \mu \mathrm{m}$ diameter aluminum jacketed optical fiber probe (Ocean Optics FOXY-AL300) is installed in the top chamber at position $\mathrm{H}$, represented as (7) in the figure. On the tip of the optical fiber probe, ruthenium complex in a sol-gel substrate is applied. The probe is connected to an excitation source and a spectrometer (Ocean Optics NEOFOX) by a bifurcated optical fiber and the entire system is used to measure the concentration of oxygen. The function of the optical fiber probe is representative of the concentration sensor described in the previous section. The NeoFOX 
unit provides connectivity to a computer via USB and has a built-in on-board pressure transducer to monitor the room pressure. Two K-type thermocouples (8) and (9) (Omega KTSS-116E-6) are installed in each chamber to monitor the temperature of each species and one is installed outside of the diffusion cell to monitor the room temperature. The two species $I$ and $j$ which are selected as the diffusion medium are oxygen gas (99.993\% purity) and nitrogen gas $(99.9999 \%$ purity) that come from compressed gas cylinders (Praxair). Appendix A contains all of the design details regarding the diffusion cell.

The oxygen sensing probe with the FOXY Formulation is designed for monitoring partial pressure of oxygen in benign gasses and aqueous liquids. Standard FOXY probe tips are covered with a layer of hydrophobic sol-gel material with a ruthenium compound trapped in the sol-gel matrix. When excited by an LED, the ruthenium complex fluoresces. If the excited ruthenium complex then encounters an oxygen molecule, the excess energy quenches the fluorescent signal. The fluorescence intensity or phase shift is measured by an Ocean Optics NeoFox phase measurement system and is related to the partial pressure of oxygen [93]. 


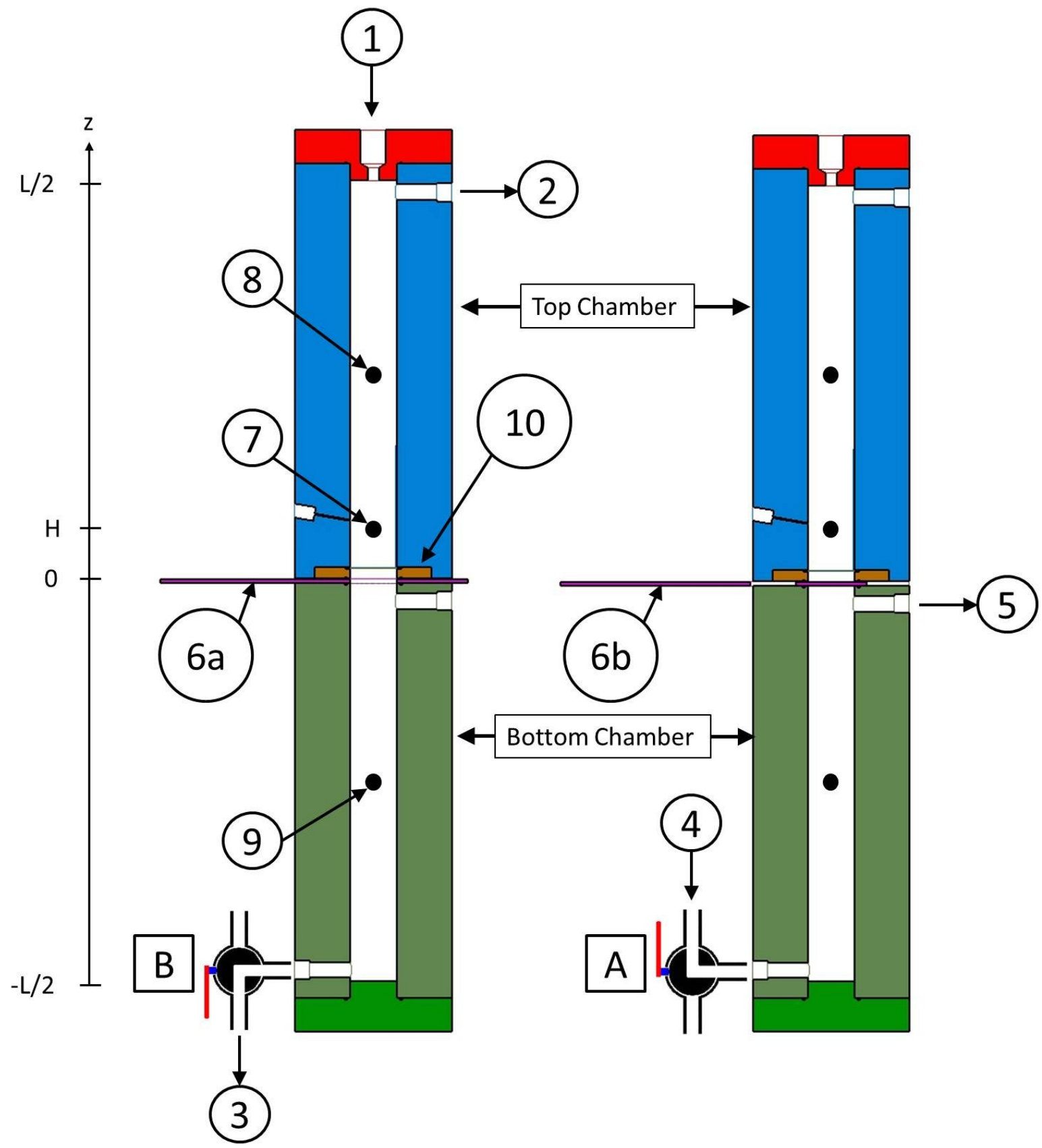

Figure 4.1 - Schematic of the modified Loschmidt cell for the measurement of effective diffusion coefficient. 1: gas inlet 1; 4: gas inlet 4; 2, 3 and 5: outlets; 6: sliding gate valve; 6(a): open position of the valve; $6(\mathrm{~b})$ : closed position of the valve; 7 : oxygen probe; 8 and 9: thermocouples; 10: sample holder. 


\subsection{Validation of the Apparatus}

To ensure that the apparatus is designed and operating correctly, a set of procedure was developed to calibrate and test the system. The apparatus for diffusion coefficient measurement needs to be validated in order to gain confidence in the results obtained from such experiments.

It is first required to calibrate the oxygen probe to the system environment and settings. Then it is necessary to perform a study of binary diffusion coefficient measurements with the working medium $\left(\mathrm{O}_{2}-\mathrm{N}_{2}\right.$ gas pair) before beginning to measure GDL samples.

\subsubsection{Areas of Uncertainty Using the Closed-Tube Method}

The closed tube method is associated with a few known difficulties which may introduce errors into the measurements. Most of these errors have been reduced or eliminated through proper design of the apparatus but should nevertheless be mentioned for completeness.

The first is associated with convective mass flux in which buoyancy effects are easily eliminated by placing the lighter gas in the top chamber of the vertically mounted apparatus. A horizontally mounted apparatus will introduce a "spillage" effect where the higher density and lower density gas will spill across the diffusion interface into the lower portion and the upper portion of the opposite chamber respectively [80].

Another convection effect arises from movement of the opening mechanism at the start of diffusion, but this has been investigated $[94,95]$ and the effect is small. For this apparatus, the speed of the sliding gate valve driven by a stepper motor has been varied to further investigate the effects of opening speed. It is observed that at opening speeds too low, the initial diffusion rate is delayed because the cross-sectional-area for diffusion is reduced. Therefore, it is found that the diffusion measurement is least affected if the opening speed is maximized to the extent of hardware limitations - in this case it is the motor controller.

Temperature gradients axially along the chamber also contribute to convection effects. Non-uniformity of gas temperatures will promote gas mixing not by means of 
composition gradients; thus affecting the diffusion coefficient. Since the gas temperatures entering the chamber are not controlled by any equipment, it is observed that there is a temperature differential between the two gases. However, the oxygen probe's sensitivity to temperature dependence is $\pm 1^{\circ} \mathrm{C}$ [96] and the temperature differential is usually no greater than this.

Other sources of uncertainty which arise from the assumptions made are the onedimensional gas diffusion (which has been validated in earlier studies [91, 92]) and the influence of the Dufour effect.

The Dufour effect (or inverse thermal diffusion) is a small temperature transient that occurs when gases interdiffuse and may occur even with ideal gases [80]. For this apparatus, it is assumed that the temperature is uniform and constant during the diffusion process, but it has already been realized by Stig Ljunggren that the Dufour effect is negligible for this type of geometry [95].

\subsubsection{System Environment and Settings}

The working medium for this apparatus is high purity nitrogen gas and oxygen gas supplied through regulated compressed cylinders. The room temperature in the laboratory where the experiments occur is typically $22^{\circ} \mathrm{C} \pm 1^{\circ} \mathrm{C}$.

The Electronic Mass Flow Controllers (Omega, FMA-5500) have a capacity of $100 \mathrm{~mL} / \mathrm{min}$ with an accuracy of $\pm 1.5 \%$ of the full scale. It receives an input signal between $0-5 \mathrm{~V}$ corresponding to flow rates of $0-100 \mathrm{~mL} / \mathrm{min}$.

The oxygen probe (Ocean Optics, FOXY AL-200M) has an $\mathrm{O}_{2} \%$ range of $0-100 \%$ with less than 5\% accuracy of reading. Its resolution is $0.05 \%$ and has a response time of less than one second.

\subsubsection{Oxygen Probe Calibration}

The oxygen sensor outputs a Tau value (given in $\mu \mathrm{sec}$ ) and translates this value into an oxygen concentration in the provided GUI software. Translation of the Tau value accurately into an oxygen concentration is only obtainable through a manual multi-point 
calibration. The idea is to subject the oxygen probe to known oxygen concentrations at constant temperature and to record the corresponding Tau value. To achieve this, it is necessary to vary the input signal $(0-5 \mathrm{~V})$ to each mass flow controller to obtain the desired oxygen concentration Figure 4.2 illustrates the data points recorded from the calibration.

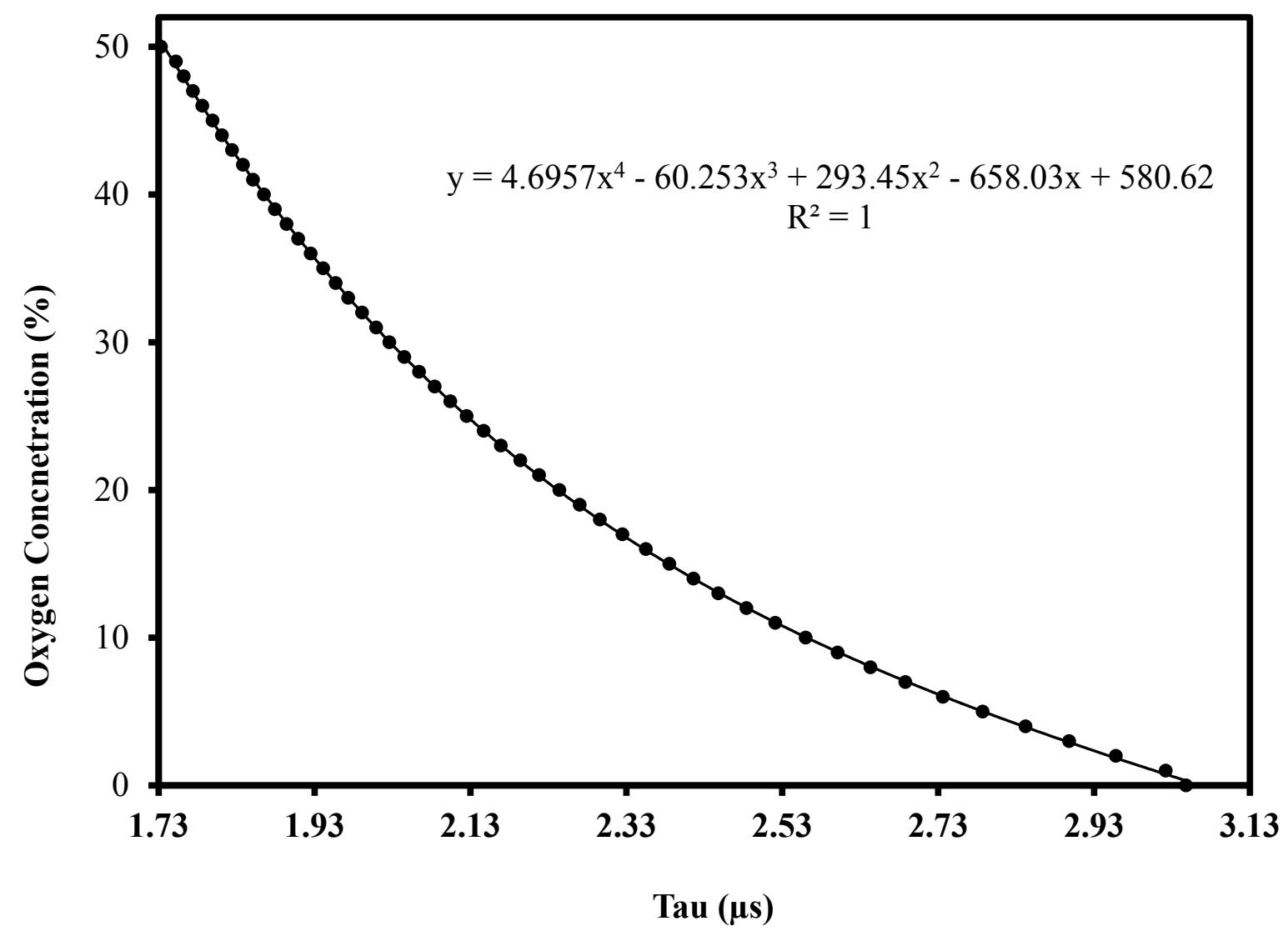

Figure 4.2 - Calibration curve of the oxygen probe from 0-50\% for room temperature.

A $4^{\text {th }}$ order polynomial curve is fitted to the data points to obtain oxygen concentration (\%) as a function of Tau $(\mu \mathrm{sec})$. This curve is used to post-process the data obtained from future measurements from this apparatus at the calibrated temperature $\pm 1{ }^{\circ} \mathrm{C}$. Due to the volume of the chambers, it is never expected to reach a concentration greater than $50 \%$ of any gas during the diffusion process (since there is $100 \%$ of each gas in each chamber at the beginning of diffusion), which explains the range of calibration points. 
Since the two sources of error (mass flow controller and oxygen sensor) are independent, the error propagation can be calculated using Pythagorean Theorem and the total error associated with each measurement after the calibration is $5.2 \%$ :

$$
\delta=\sqrt{(1.5 \%)^{2}+(5 \%)^{2}}=5.2 \%
$$

\subsubsection{Gas Containment Ability of Apparatus}

This study is performed to determine the ability of the apparatus to contain nitrogen gas in the top chamber while the bottom chamber is being filled with oxygen gas. The difficulty here is due to the sliding gate valve because it is required to slide smoothly between two O-rings under compression while maintaining a good seal between the chambers and with the room environment. It is possible to have no gas leakage by increasing the compression of the O-rings but this would significantly increase the friction between the sliding gate valve and O-rings such that during operation, the O-rings could get pulled out of their seat (O-ring groove) or could fail due to shear. Figure 4.3 shows an example of the amount of gas "leakage" over a period of time during the measurement process. 


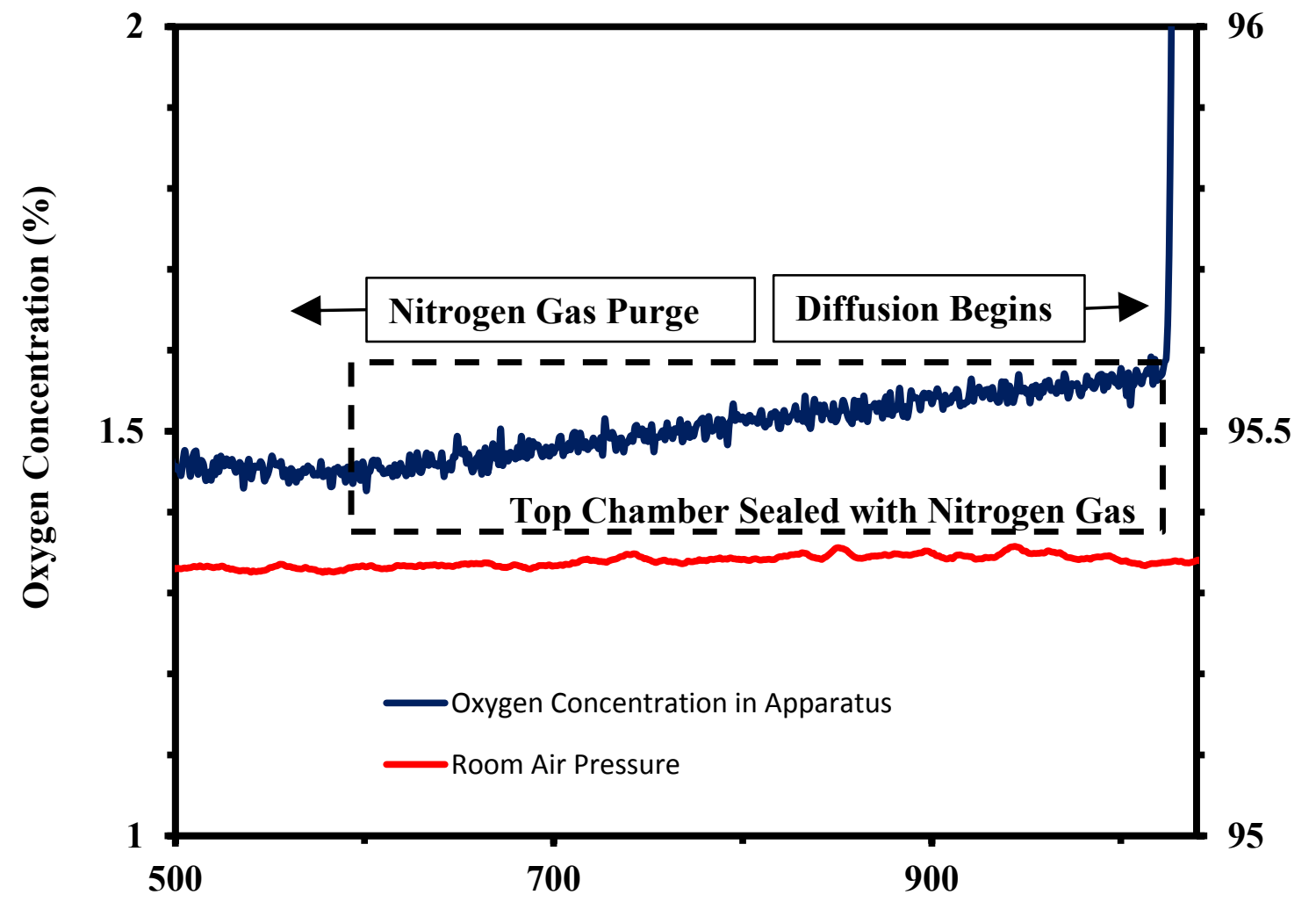

Time (s)

Figure 4.3 - Oxygen concentration in the nitrogen chamber after the nitrogen purging and before the diffusion process.

From Figure 4.3 it is seen that from about 550 s to 1020 s, when the top chamber is sealed-off with nitrogen gas and the bottom chamber is being filled with oxygen gas, the increase in oxygen concentration is about $0.15 \%$ in the top chamber. Assuming this trend to be linear, the rate of leakage in the top chamber is approximately $1.15 \% \mathrm{O}_{2} /$ hour before the diffusion process begins. The magnitude of this leakage is considered insignificant when considering the duration of the experiment ( 6 minutes diffusion of 23 minutes total) and is thus ignored.

\subsubsection{H-calibration and Bulk Diffusion Coefficient Measurements}

All measurements are performed at room pressure and temperatures about $22^{\circ} \mathrm{C} \pm$ $1{ }^{\circ} \mathrm{C}$. Due to the nature of the room (ventilation and weather condition), the pressure 
variations can differ by as much as $3 \mathrm{kPa}$ between different days (94kPa $-97 \mathrm{kPa})$. To mitigate the effects of pressure fluctuations and temperature on diffusion, these parameters were recorded and considered for each measurement rather than assuming standard conditions (i.e. Standard conditions for temperature and pressure, STP).

The apparatus can be used to measure the bulk diffusion coefficient of $\mathrm{O}_{2}-\mathrm{N}_{2}$ as a calibration procedure by removing any obstacles, i.e. porous layer, in between the two diffusing gas species. When there are no porous layer(s) installed in the sample holder, the equivalent diffusion coefficient in Eq. (3.3) becomes the bulk diffusion coefficient: $D_{i}^{\mathrm{eq}}=$ $D_{i}^{\text {bulk. }}$

The bulk diffusion coefficient, $D_{i}^{\text {bulk }}\left[\mathrm{m}^{2} / \mathrm{s}\right]$, can be calculated with good accuracy (up to $3 \%$ error) and for an $\mathrm{O}_{2}-\mathrm{N}_{2}$ gas pair it can be calculated by [80]

$$
\ln \left(p \cdot D_{i}^{\text {bulk }}\right)=\ln \left(1.13 \times 10^{-5}\right)+1.724 \cdot \ln (T)
$$

where $p$ is the total pressure $[\mathrm{Atm}]$ and $T$ is the gas temperature $[\mathrm{K}]$ and are both measured quantities taken as the average recorded room pressure and oxygen gas temperature, respectively, in this study. The pressure in the chamber is assumed to be equal to the room pressure (which is monitored) because the gases purge to the room during filling. The accuracy of the pressure and temperature readings from the equipment is $\pm 0.1 \mathrm{kPa}$ and \pm $0.1^{\circ} \mathrm{C}$ respectively. This combination of error is insignificant when compared to the accuracy of the equation itself in predicting the binary diffusion coefficient of an oxygen-nitrogen mixture (1-3\% error [80]).

The average room pressure and $\mathrm{O}_{2}$ temperature in the bottom chamber can be used because the variation of these parameters during the experiment is very small as seen in Figure 4.4 and Figure 4.5 respectively. Figure 4.6 shows the oxygen concentration adjustment performed by the oxygen sensor while it encountered changes in the room pressure. 


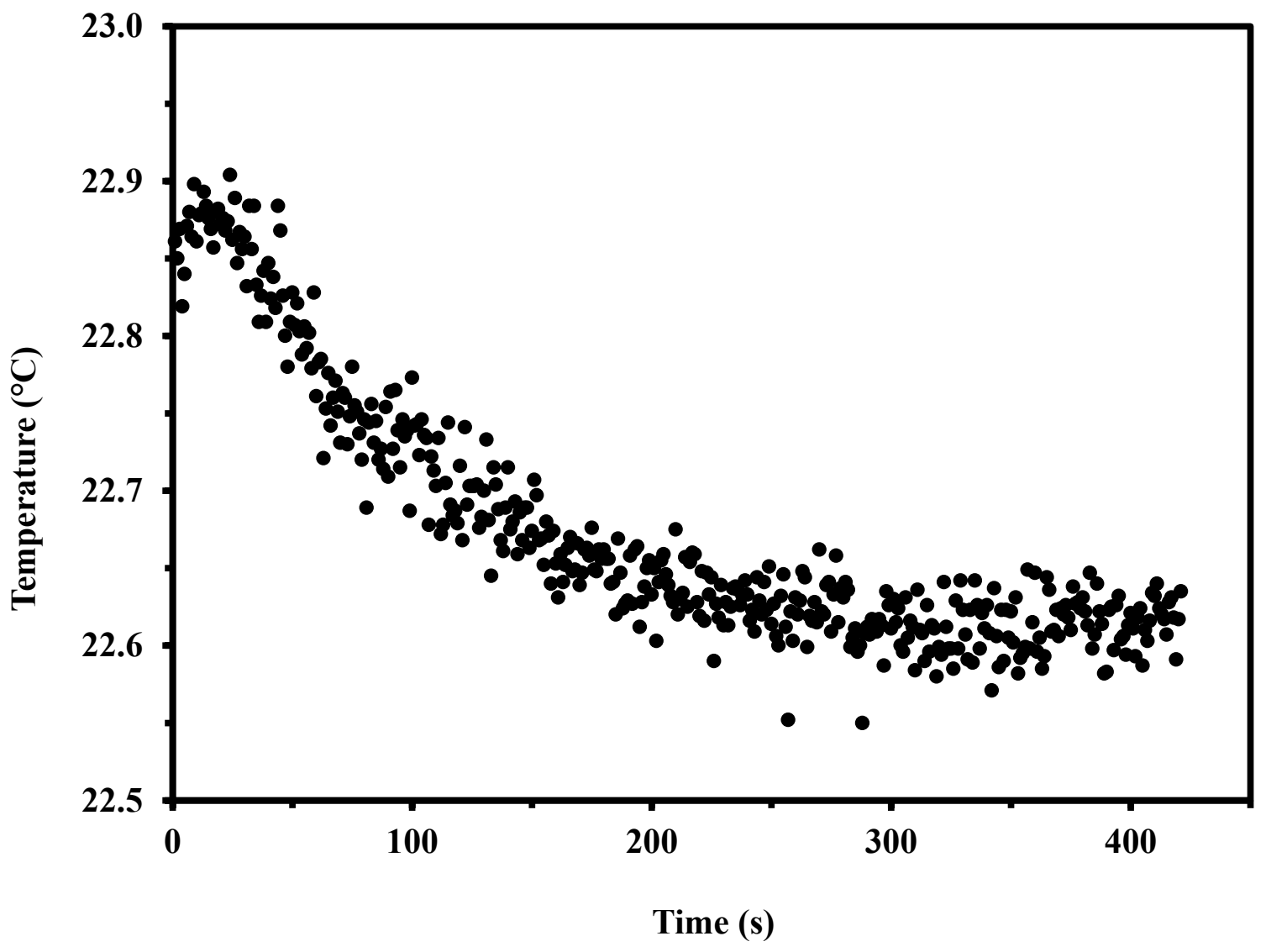

Figure 4.4 - This chart illustrates that there is minimal change in the oxygen gas temperature $\left(\sim 0.3^{\circ} \mathrm{C}\right)$ during the diffusion process and therefore an average oxygen temperature value can be taken. 


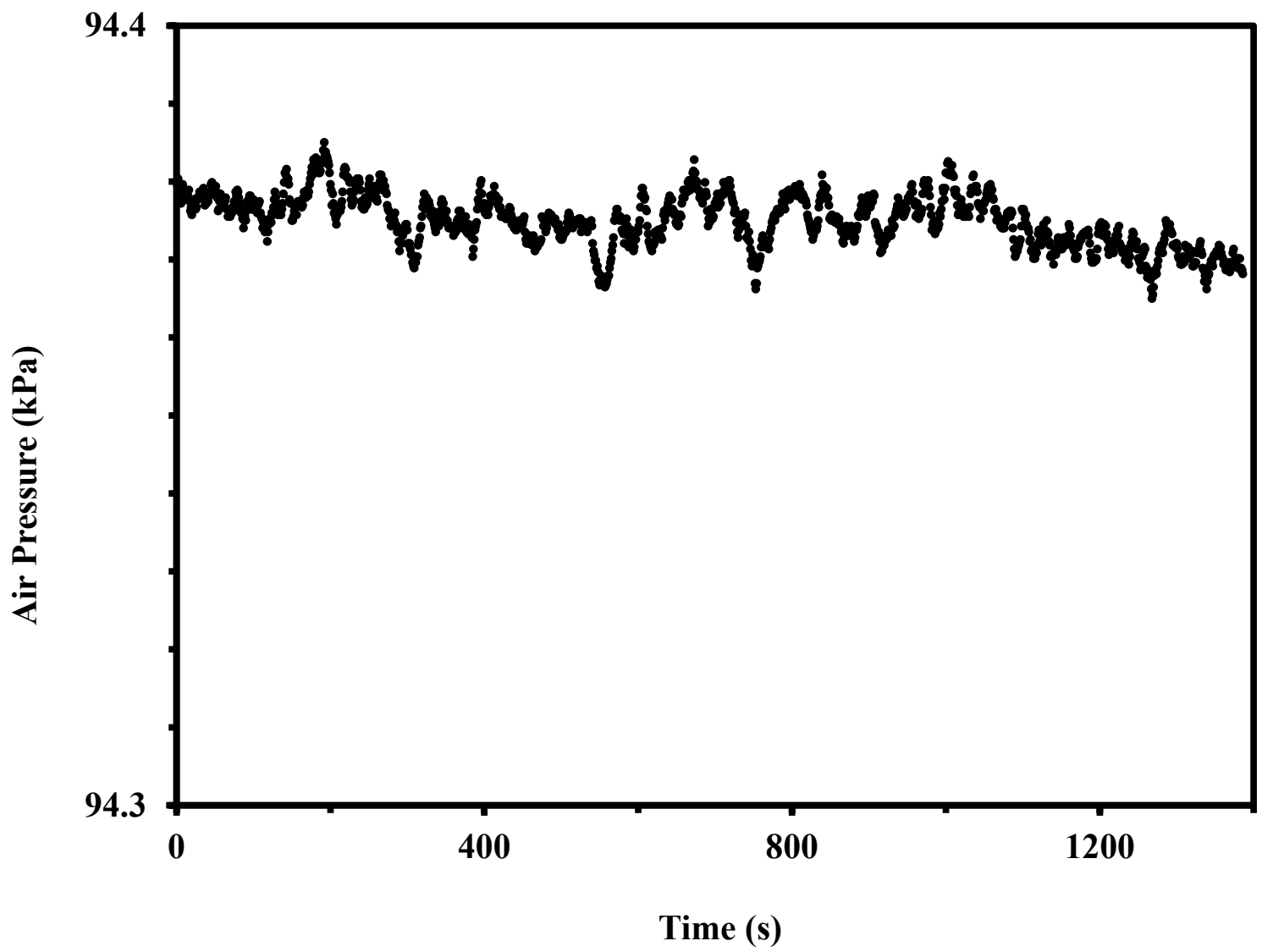

Figure 4.5 - This chart illustrates that there is negligible change in the room pressure during one measurement and therefore an average pressure can be taken. 


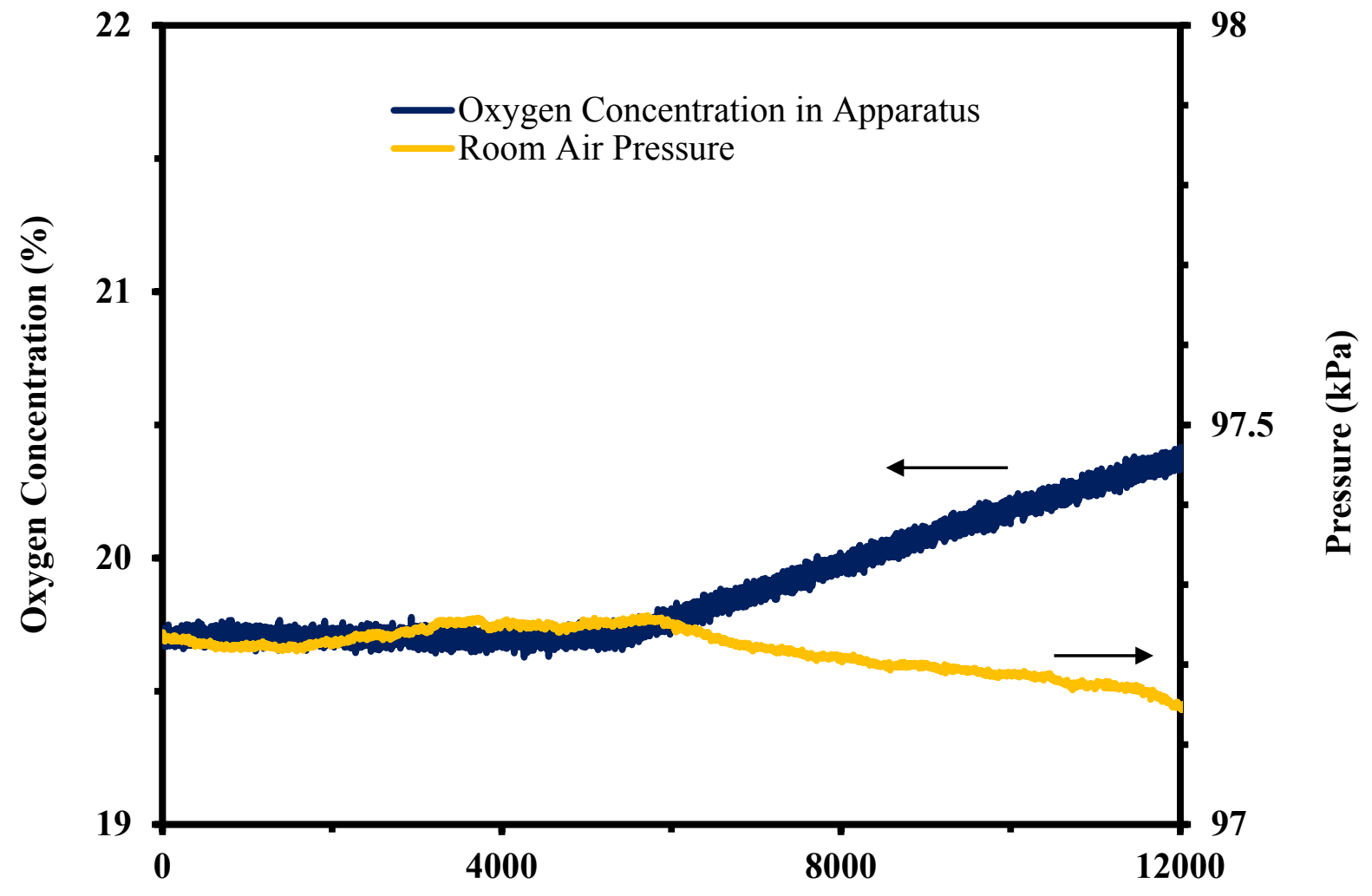

Time (s)

Figure 4.6 - This chart shows that as room pressure changes, the partial pressure of oxygen changes thus reducing the oxygen concentration measured by the oxygen sensor.

$\mathrm{H}$-calibration of the apparatus is performed by determining the sensor distance, $\mathrm{H}$, which consistently yields the best agreement between the $D_{i}^{\text {bulk }}$ calculated from Eq. (4.1) and $D_{i}^{\text {bulk }}$ obtained from curve fitting Eq. (3.3) to experimental bulk diffusion measurements. Although the oxygen probe hole location is known from the design of the apparatus, the location of the oxygen probe tip $(z=H)$ with reference to the interface of the two chambers $(\mathrm{z}=0)$ is not known with good accuracy.

The $D_{i}^{\text {bulk }}$ of $\mathrm{O}_{2}-\mathrm{N}_{2}$ is measured at room pressure and temperature about 20 times on different days to obtain the value $\mathrm{H}$ which fits Eq. (3.3) to within $5.2 \%$ of the $D_{i}^{\text {bulk }}$ from Eq. 
(4.1). The value $\mathrm{H}$ remains fixed once it is determined and is used in Eq. (3.3) for curve fitting all future measurements thereafter provided that no physical changes are made to the apparatus. A H-calibration must be performed again if any physical system changes are made. The 5.2\% acceptable limit is derived from the total error associated with the equipment during calibration of the oxygen sensor.

\subsubsection{Validation Results}

Figure 4.7 shows the comparison between the measured and literature values for oxygen-nitrogen bulk diffusion coefficient after a H-calibration. Actual values can be found in Appendix B. Marrero et al. [80] state that for oxygen-nitrogen diffusion (Group III gas pair) the measurements are only accurate up to $1-3 \%$. Though considering that the minimum error associated with the test equipment is $|5.2 \%|$, the measured bulk diffusion coefficients are considered acceptable if they fall within this limit of the corresponding literature value determined using Eq. (4.1). This step is performed not only to validate the apparatus but also to check that the apparatus is functioning properly each time before performing measurements on porous material. 


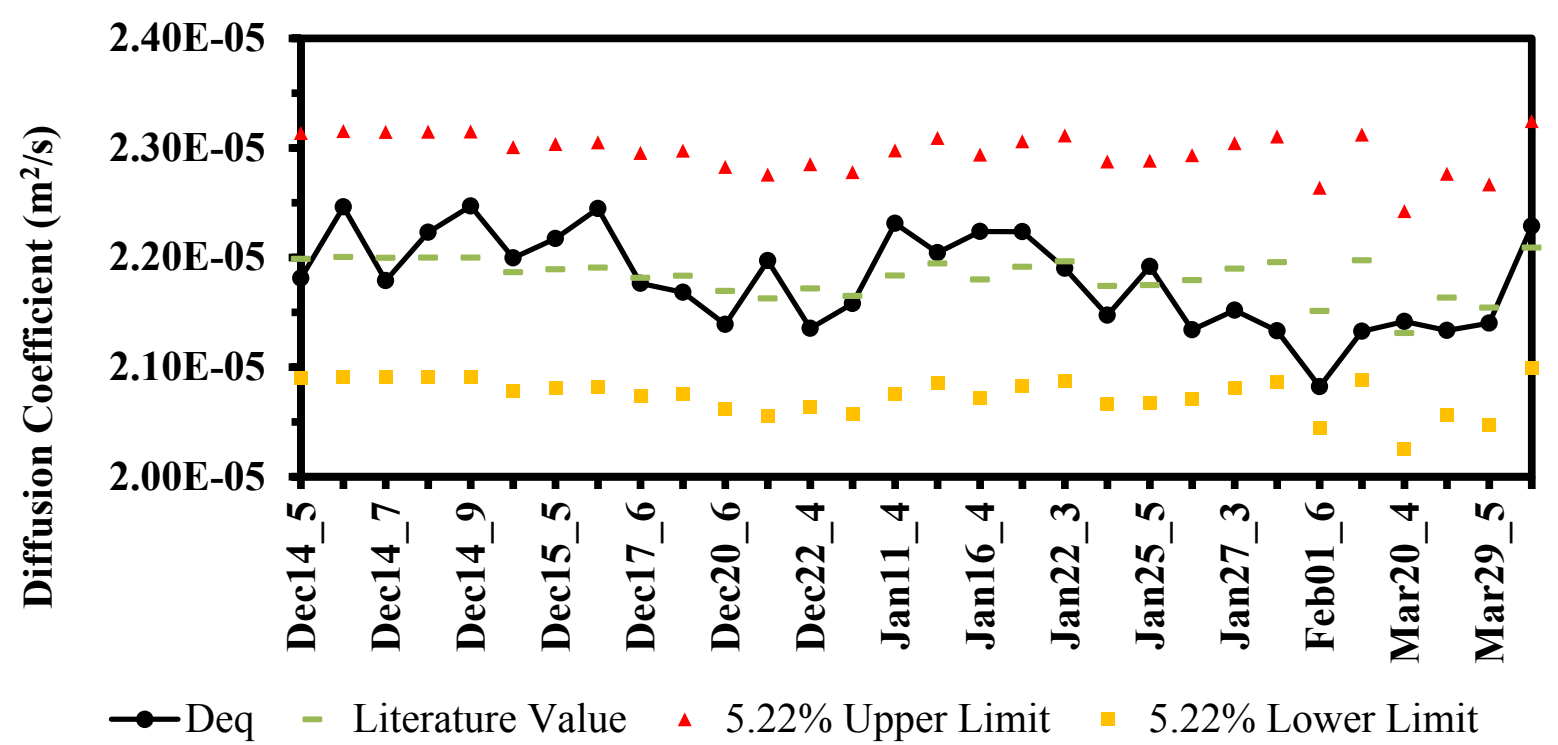

Figure 4.7 - Comparison of the binary diffusion coefficients measured experimentally to those determined from Eq. (4.1) with 5.2\% upper and lower bounds.

\subsection{Operation}

The system first begins saturated in the room environment. Power supplies, electronic controllers, gas supplies, the NeoFox spectrometer, and the computer must all be manually switched on. The Diffusion System Control Program (DSCP) must also be open, see Appendix C.

Before samples are placed into the apparatus for measurements, it is first required to run several bulk gas diffusion runs (with the $\mathrm{O}_{2}-\mathrm{N}_{2}$ gas pair) until the equipment reaches its steady operating conditions. The apparatus is considered to be ready for measurements when it is seen that the measured bulk diffusion coefficient is repeatable and is within $\pm 5.2 \%$ of the calculated value using Eq. (4.1). If this is satisfied, the sample holder is then disassembled from the apparatus for installation of the porous sample of interest. Once the sample holder is properly re-installed into the apparatus, the experiments resume accordingly. It should be noted that after each test, the chambers are separated and left open to the room environment for a short period of time to allow the oxygen gas in the chambers to escape (to lower the 
oxygen concentration in the top chamber allowing for a shorter purge duration) before the next test begins.

The schematic gas flow diagram is available in Appendix A for reference. At the "home" position, all two-way solenoid valves are normally-closed, the three-way-valve is normally in position (A) and the gate valve is normally in position (6a), refer to Figure 4.1. Activation of the valves is automatically controlled by the DSCP.

When the DSCP is activated, nitrogen gas is released at a rate of $20 \mathrm{~mL} / \mathrm{min}$ from mass flow controller (MFC) (N) through inlet (1) and exits at outlet (3) for 10 minutes. This procedure is performed to rid of oxygen or other gases in the top chamber. Considering that the internal volume of each chamber is about $60 \mathrm{~mL}$, it would only take six minutes to fill both chambers at this flow rate but the extra 4 minutes ensures complete purging of the chambers. Although the mass flow controllers have a capacity of $100 \mathrm{~mL} / \mathrm{min}$ - which would decrease the purge time significantly - it was not selected because a decreased flow rate would allow a more laminar flow to enter the chamber thus reducing the possibility of gas mixing.

At 10 minutes, the sliding gate valve begins closing off the top chamber, position (6b). When the gate valve has completed closing, MFC (N) is then set back to zero and outlet (2) is open to room pressure for two seconds. This allows for the remainder of the gas in the supply line to enter the chamber while venting to room pressure (to prevent pressurizing the chamber). After these two seconds oxygen gas is released at a rate of $20 \mathrm{~mL} / \mathrm{min}$ from MFC (O) through inlet (4) and exits at outlet (5) for six minutes. Similarly, extra fill time than theoretically necessary is added to ensure complete purging of the nitrogen gas in the bottom chamber.

After six minutes, MFC $(\mathrm{O})$ is set back to zero and two seconds thereafter, inlet (4) is closed. Outlet (5) is closed four seconds later to equalize chamber pressure with room pressure. At this point, the top and bottom chambers are filled with $100 \%$ concentration of nitrogen and oxygen gas respectively at room pressure. The data recording begins for one minute with the gate valve still in position (6b). After one minute, diffusion begins when the 
gate valve returns to position (6a) and the oxygen concentration in the top chamber is recorded for the remaining six minutes. The DSCP automatically stops recording data after this time which concludes one measurement run. 


\section{Chapter 5}

\section{GDL Sample Measurements}

In this section, the results of through-plane effective diffusion coefficients for different GDLs are presented. Likewise to the calibration and validation, the measurements were also conducted at room temperature and pressure such that comparisons can be made with available data in literature.

\subsection{GDL Sample Selection}

GDL samples from Toray, SolviCore and Sigracet $\AA$ are measured to determine the effect of Teflon treatment, GDL thickness and MPL coating on the effective diffusion coefficient. For the Toray samples, the TGP-H-120 and TGP-H-060 series GDL with 0\%, $30 \%$ and $60 \%$ PTFE loading (all without MPL) are used. For the SolviCore samples, Type A series GDL with 5\% PTFE loading (without MPL coating), and Type A and B series GDL both with MPL coating are tested. For the SGL Sigracet ${ }^{\circledR}$ samples, 10-series GDL with $0 \%$ and 5\% PTFE loading (without MPL coating), and 25-series GDL with 20\% PTFE and MPL coating are tested.

A characteristic of the GDL not published by some manufacturers is the porosity. The average porosity of each GDL sample used in the experiment is obtained using a weighing method. The sample is first evacuated to ensure that it is completely dry and its mass is measured. It is then saturated with Octane and re-measured to obtain the total volume of available pores (see Appendix D). Table 5.1 shows the measurements obtained for each of the samples as well as other technical characteristics. The measured porosity value shown in the table is the average of 10 different measurements for each sample with its associated $95 \%$ confidence interval. Table 5.2 compares the microstructure of several GDL samples tested in this work. 
Table 5.1 - Summary of GDL sample selection and other technical characteristics.

\begin{tabular}{|c|c|c|c|c|c|}
\hline & \multirow[b]{2}{*}{ Description } & \multicolumn{2}{|c|}{ Manufacturer } & \multicolumn{2}{|c|}{ Measured } \\
\hline & & $\begin{array}{l}\text { Porosity } \\
(\%)\end{array}$ & $\begin{array}{l}\text { Thickness } \\
\quad(\mu \mathrm{m})\end{array}$ & $\begin{array}{l}\text { Porosity } \\
(\%)\end{array}$ & $\begin{array}{l}\text { Thickness } \\
( \pm 10 \mu \mathrm{m})\end{array}$ \\
\hline \multirow{6}{*}{$\stackrel{\vec{\pi}}{0}$} & TGP-H-120 RAW & 78 & 370 & $70.9 \pm 0.8$ & 370 \\
\hline & TGP-H-120 30\% PTFE & - & 370 & $61.8 \pm 1.5$ & 400 \\
\hline & TGP-H-120 60\% PTFE & - & 370 & $36.7 \pm 3.0$ & 400 \\
\hline & TGP-H-060 RAW & 78 & 190 & $74.8 \pm 0.6$ & 220 \\
\hline & TGP-H-060 30\% PTFE & - & 190 & $64.4 \pm 1.1$ & 210 \\
\hline & TGP-H-060 60\% PTFE & - & 190 & $46.4 \pm 1.4$ & 210 \\
\hline \multirow{3}{*}{ 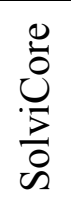 } & Type A, 5\% PTFE & - & - & $81.9 \pm 0.2$ & 210 \\
\hline & Type A, MPL & - & - & $75.0 \pm 0.9$ & 250 \\
\hline & Type B, MPL & - & - & $76.5 \pm 1.2$ & 230 \\
\hline \multirow{3}{*}{ 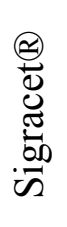 } & 10AA (RAW) & - & $390 \pm 70$ & $84.2 \pm 0.3$ & 400 \\
\hline & 10BA (5\% PTFE) & 88 & $400 \pm 70$ & $81.8 \pm 0.4$ & 370 \\
\hline & $\begin{array}{l}25 \mathrm{DC}(20 \% \mathrm{PTFE}+ \\
\mathrm{MPL})\end{array}$ & - & $235 \pm 35$ & $76.8 \pm 0.3$ & 250 \\
\hline
\end{tabular}


Table 5.2 - Comparison of microstructure for some GDL samples taken from SEM.
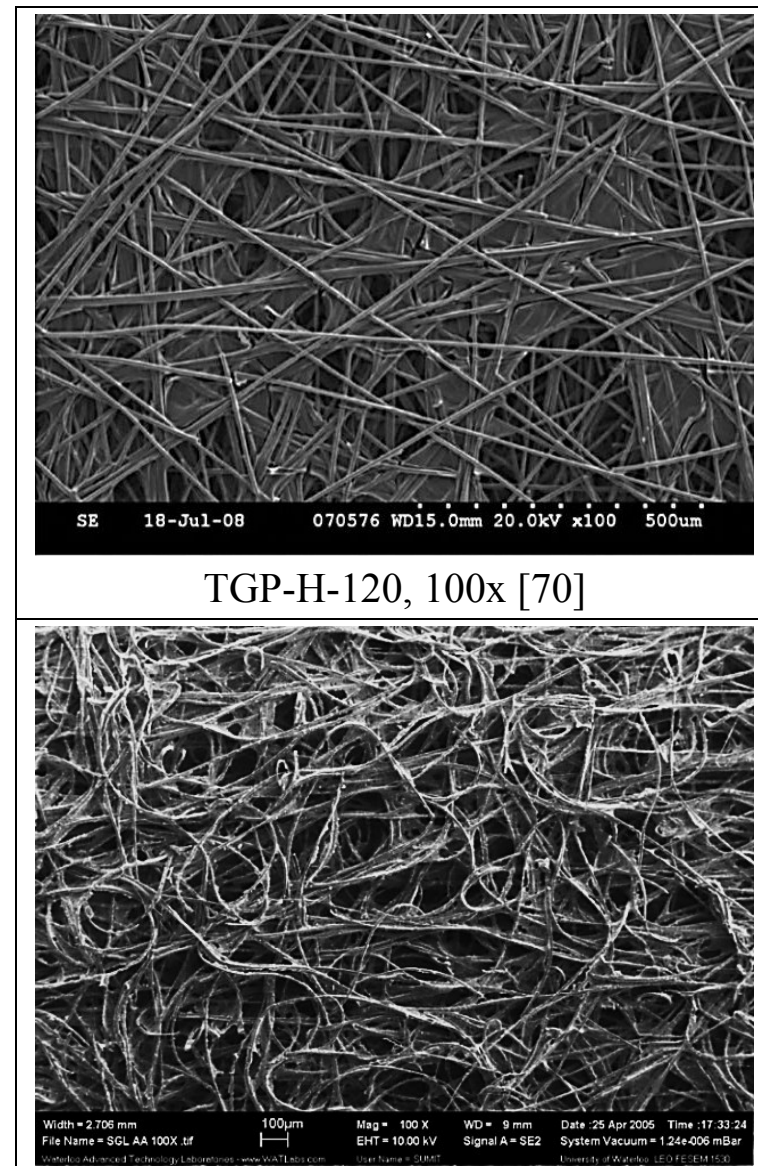

Sigracet ${ }^{\circledR} 10$ AA, 100x [97]

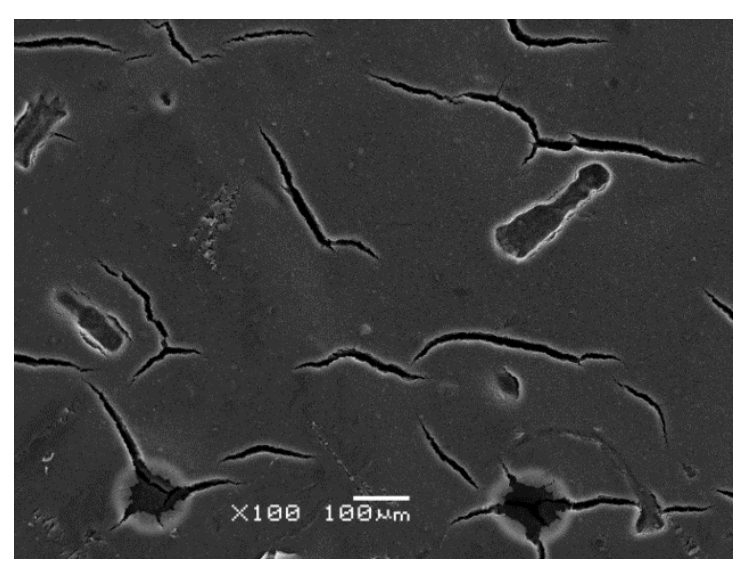

Sigracet ${ }^{\circledR} 25$ DC, 100x

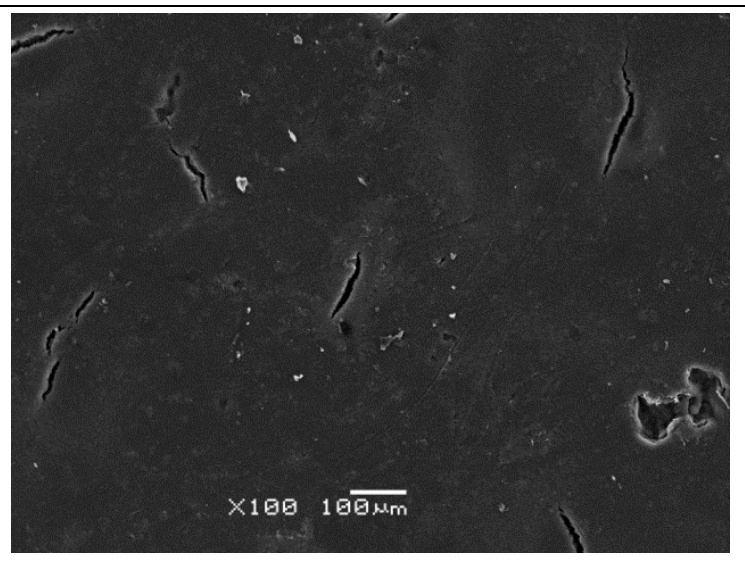

SolviCore Type A MPL, 100x

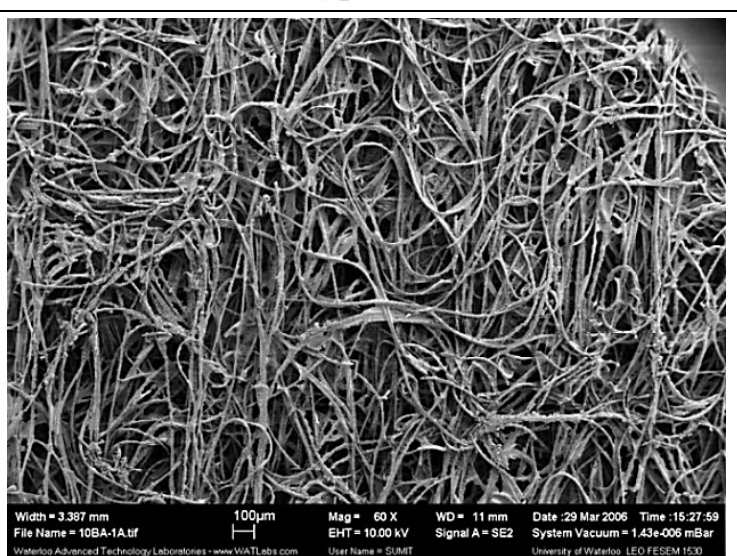

Sigracet ${ }^{\circledR} 10$ BA, 100x [97]

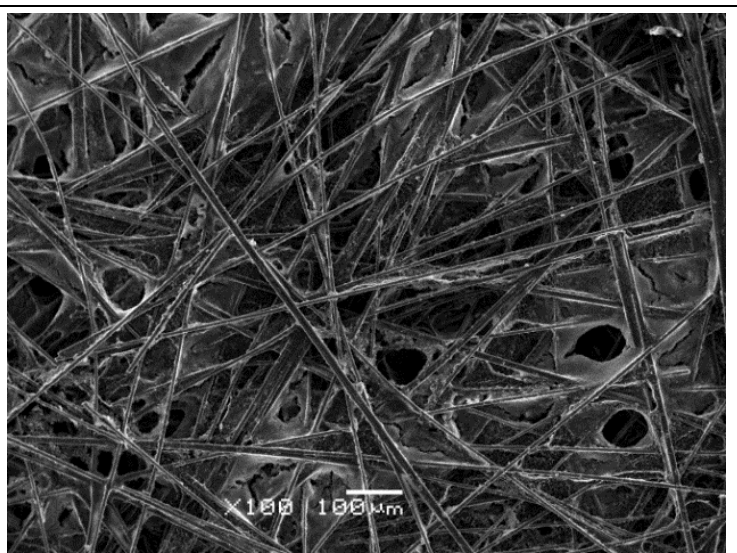

SolviCore Type B with MPL (non-coated side shown), 100x 


\subsection{Equivalent Diffusion Coefficient Measurements}

To determine the effective diffusion coefficient through the GDL substrate or the MPL coating, the measured concentration history is similarly fitted to Eq. (3.3) to first obtain the $D_{i}^{\text {eq }}$. For a GDL sample without MPL, only one porous layer is present because the GDL substrate has a relatively uniform pore structure throughout its diffusion length, thus Eq. (3.8) is used to calculate the $D_{i}^{\text {eff, } 1}$. In the presence of MPL coating, the GDL substrate and the coating must be analyzed separately because of their drastically different pore structure. The MPL typically contains pore diameters less than $1 \mu \mathrm{m}$ whereas the GDL substrate is in the order of macropores and this is similar to having two independent porous layers. As a result, eq. (3.11) is used to calculate the effective diffusion coefficient of the MPL as $D_{i}^{\text {eff,top }}$.

To assess the quality and to judge the trustworthiness of the non-linear curve fit, the curve fitting program used must show a successful fit (fit convergence) while maintaining the specified tolerance and reducing the Chi-square value. If these parameters are met, then the $D_{i}^{\mathrm{eq}}$ obtained from curve fitting is presumed acceptable.

For each data point obtained, a minimum of 10 to 20 or more repeated measurements were performed on different days at different times of the day to confirm repeatability and accuracy of the data measured as shown in Appendix E.

Considering the equipment error and other measurement errors (such as thickness of the porous sample and bulk diffusion coefficient accuracy), the total error associated with

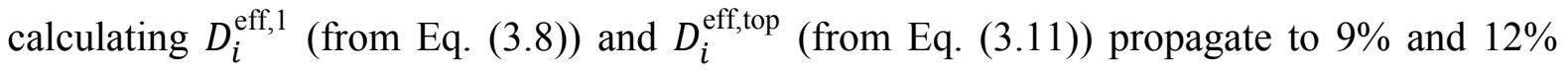
respectively in a conservative estimate and these calculations can be found at the end of Appendix E.

Chauvenet's criterion [98] is applied to each data set to reject outlier data based on statistical methods. The $95 \%$ confidence interval is calculated for each sample based on the sample standard deviation and t-distribution. Table 5.3, Table 5.4 and Table 5.5 each summarize the results for the Toray, SolviCore and Sigracet ${ }^{\circledR}$ samples respectively. 
Table 5.3 - Summary of measured results for Toray samples.

\begin{tabular}{|c|c|c|c|c|c|c|}
\hline & $\begin{array}{c}\text { Toray } \\
\text { TGP-H- } \\
\text { 120-60 }\end{array}$ & $\begin{array}{c}\text { Toray } \\
\text { TGP-H- } \\
\text { 120-30 }\end{array}$ & $\begin{array}{c}\text { Toray } \\
\text { TGP-H- } \\
120\end{array}$ & $\begin{array}{c}\text { Toray } \\
\text { TGP-H- } \\
060-60\end{array}$ & $\begin{array}{c}\text { Toray } \\
\text { TGP-H- } \\
\text { 060-30 }\end{array}$ & $\begin{array}{c}\text { Toray } \\
\text { TGP-H- } \\
060\end{array}$ \\
\hline $\begin{array}{l}\text { Thickness } \\
{[ \pm 10 \mu \mathrm{m}]}\end{array}$ & 400 & 400 & 370 & 210 & 210 & 220 \\
\hline $\begin{array}{c}\text { PTFE Loading } \\
{[\%]}\end{array}$ & 60 & 30 & 0 & 60 & 30 & 0 \\
\hline Porosity [\%] & 36.7 & 61.8 & 70.9 & 46.4 & 64.4 & 74.8 \\
\hline $\begin{array}{c}\text { Porosity [\%] } \\
\text { 95\% C.I. }\end{array}$ & 3 & 1.5 & 0.8 & 1.4 & 1.1 & 0.6 \\
\hline$Q( \pm 9.5 \%)$ & 0.015 & 0.159 & 0.258 & 0.055 & 0.158 & 0.291 \\
\hline $\begin{array}{c}Q \\
95 \% \text { C.I. }\end{array}$ & 0.0003 & 0.031 & 0.029 & 0.0062 & 0.021 & 0.054 \\
\hline $\begin{array}{c}D_{\text {eff }}\left[\mathrm{m}^{2} / \mathrm{s}\right] \\
( \pm 9 \%)\end{array}$ & $3.22 \mathrm{E}-07$ & $3.49 \mathrm{E}-06$ & $5.62 \mathrm{E}-06$ & $1.20 \mathrm{E}-06$ & $3.46 \mathrm{E}-06$ & $6.37 \mathrm{E}-06$ \\
\hline $\begin{array}{l}D_{\text {eff }}\left[\mathrm{m}^{2} / \mathrm{s}\right] \\
95 \% \text { C.I. }\end{array}$ & 7.1E-09 & 6.9E-07 & $6.2 \mathrm{E}-07$ & $1.4 \mathrm{E}-07$ & 4.6E-07 & $1.2 \mathrm{E}-06$ \\
\hline
\end{tabular}

Table 5.4 - Summary of measured results for SolviCore samples.

\begin{tabular}{|c|c|c|c|}
\hline & $\begin{array}{c}\text { SolviCore } \\
\text { Type A 5\% } \\
\text { PTFE }\end{array}$ & $\begin{array}{c}\text { SolviCore } \\
\text { Type A } \\
\text { MPL }\end{array}$ & $\begin{array}{c}\text { SolviCore } \\
\text { Type B } \\
\text { MPL }\end{array}$ \\
\hline $\begin{array}{l}\text { Thickness } \\
{[ \pm 10 \mu \mathrm{m}]}\end{array}$ & 210 & 250 & 230 \\
\hline $\begin{array}{c}\text { PTFE Loading } \\
{[\%]}\end{array}$ & 5 & 30 & 0 \\
\hline Porosity [\%] & 81.9 & 75.0 & 76.5 \\
\hline $\begin{array}{c}\text { Porosity [\%] } \\
\text { 95\% C.I. }\end{array}$ & 0.2 & 0.9 & 1.2 \\
\hline$Q( \pm 9.5 \%)$ & 0.334 & 0.141 & 0.154 \\
\hline $\begin{array}{c}Q \\
\text { 95\% C.I. }\end{array}$ & 0.068 & 0.01 & 0.018 \\
\hline $\begin{array}{c}D_{\text {eff }}\left[\mathrm{m}^{2} / \mathrm{s}\right] \\
( \pm 9 \%)\end{array}$ & 7.33E-06 & $3.07 \mathrm{E}-06$ & $3.35 \mathrm{E}-06$ \\
\hline $\begin{array}{l}D_{\text {eff }}\left[\mathrm{m}^{2} / \mathrm{s}\right] \\
95 \% \text { C.I. }\end{array}$ & $1.5 \mathrm{E}-06$ & $2.2 \mathrm{E}-07$ & $3.8 \mathrm{E}-07$ \\
\hline
\end{tabular}


Table 5.5 - Summary of measured results for SGL Sigracet ${ }^{\circledR}$ samples.

\begin{tabular}{|c|c|c|c|}
\hline & $\begin{array}{c}\text { SGL } 10 \\
\text { AA }\end{array}$ & $\begin{array}{c}\text { SGL } 10 \\
\text { BA }\end{array}$ & $\begin{array}{c}\text { SGL } 25 \\
\text { DC }\end{array}$ \\
\hline $\begin{array}{l}\text { Thickness } \\
{[ \pm 10 \mu \mathrm{m}]}\end{array}$ & 400 & 370 & 250 \\
\hline $\begin{array}{c}\text { PTFE Loading } \\
{[\%]}\end{array}$ & 0 & 5 & 20 \\
\hline Porosity [\%] & 84.2 & 81.8 & 76.8 \\
\hline $\begin{array}{c}\text { Porosity [\%] } \\
\text { 95\% C.I. }\end{array}$ & 0.3 & 0.4 & 0.3 \\
\hline$Q( \pm 9.5 \%)$ & 0.393 & 0.359 & 0.139 \\
\hline $\begin{array}{c}\text { Q } \\
\text { 95\% C.I. }\end{array}$ & 0.052 & 0.044 & 0.014 \\
\hline $\begin{array}{c}D_{\text {eff }}\left[\mathrm{m}^{2} / \mathrm{s}\right] \\
( \pm 9 \%)\end{array}$ & $8.54 \mathrm{E}-06$ & $7.85 \mathrm{E}-06$ & $3.04 \mathrm{E}-06$ \\
\hline $\begin{array}{l}D_{\text {eff }}\left[\mathrm{m}^{2} / \mathrm{s}\right] \\
95 \% \text { C.I. }\end{array}$ & $1.1 \mathrm{E}-06$ & 9.7E-07 & $3.0 \mathrm{E}-07$ \\
\hline
\end{tabular}




\section{Chapter 6}

\section{Discussion}

\subsection{Effect of PTFE Loading}

As shown in Table 5.1, PTFE loading decreases the overall porosity of the GDL and thus decreases the effective diffusion coefficient of GDL as shown in Figure 6.1. Samples from all three manufacturers show a decreasing trend as PTFE loading is increased, but the Toray samples clearly show an almost linear decrease in diffusibility as PTFE loading is increased from $0 \%$ to $60 \%$. It is difficult to compare the slopes between the different manufacturers and in some cases even within the same manufacturer because at a similar PTFE loading, the average porosity is different. This is partially a result of different manufacturing techniques practiced, which lends to variation in microstructure and composition. Regardless, increase in PTFE loading results in closing off pores, which were

previously available to diffusion. However, the use of PTFE is still crucial in liquid water management. Therefore, the amount of PTFE content should be optimized between the need for gas transport and water removal at high current operation of the cell. 


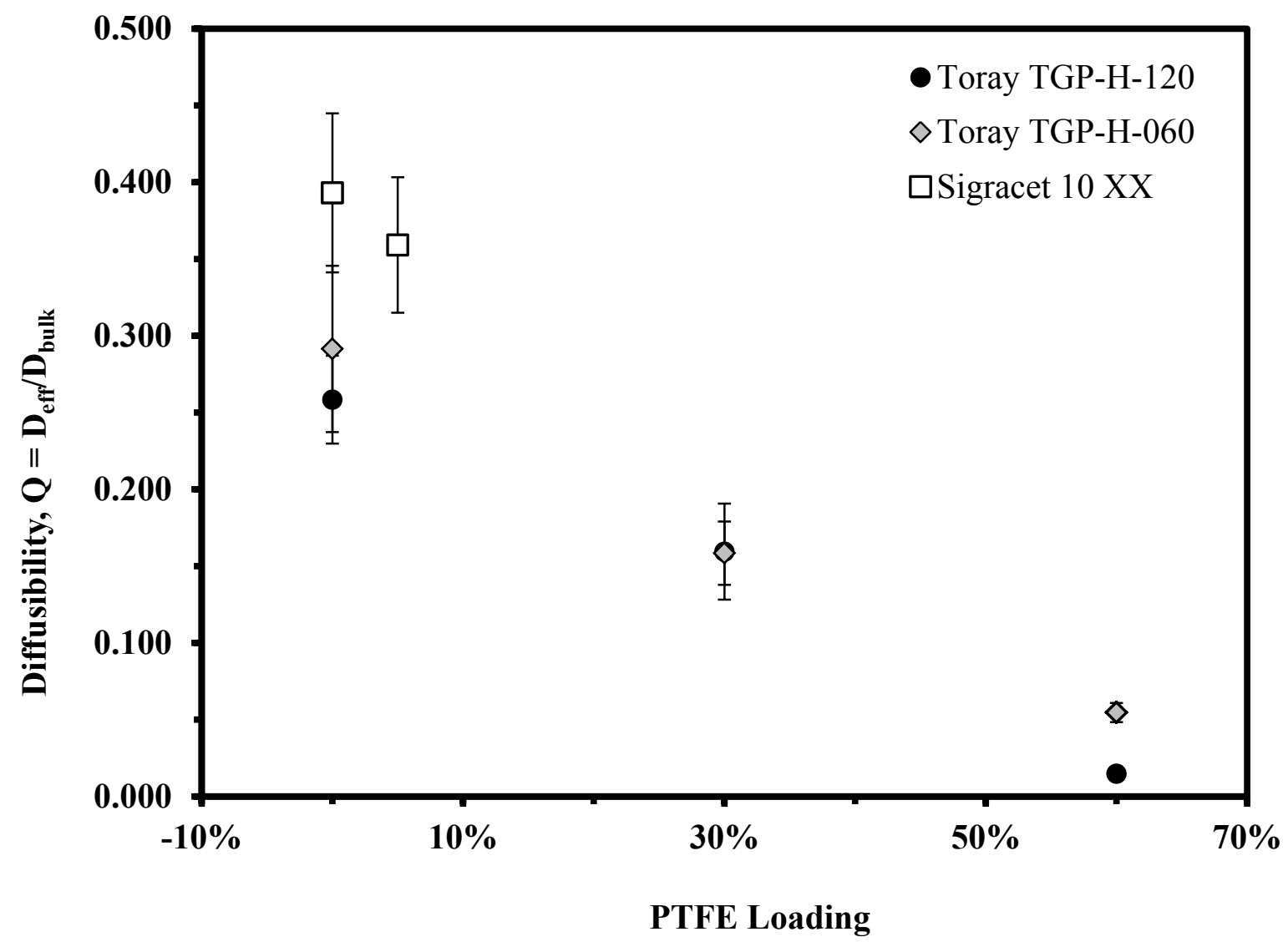

Figure 6.1 - Effect of PTFE loading on the effective diffusion coefficient in the throughplane direction.

\subsection{Effect of Thickness}

From Figure 6.2, sample thickness is shown to have no apparent effect on the diffusibility of Toray GDL. For the 0\% PTFE and 30\% PTFE loaded samples, the measured values are within the error range of their respective pairs, suggesting that thickness effects are negligible as they should be. However, it seems otherwise for the $60 \%$ PTFE loading samples. The explanation for this is that the porosity between the TGP-H-060 and TGP-H120 series sample at $60 \%$ PTFE loading differ by almost $10 \%$ (see Table 5.1), thus resulting into 3.5 times difference in the diffusibility between these two samples. Since the porosity variation is so drastic, it plays a dominant role for the $60 \%$ PTFE loaded samples. 


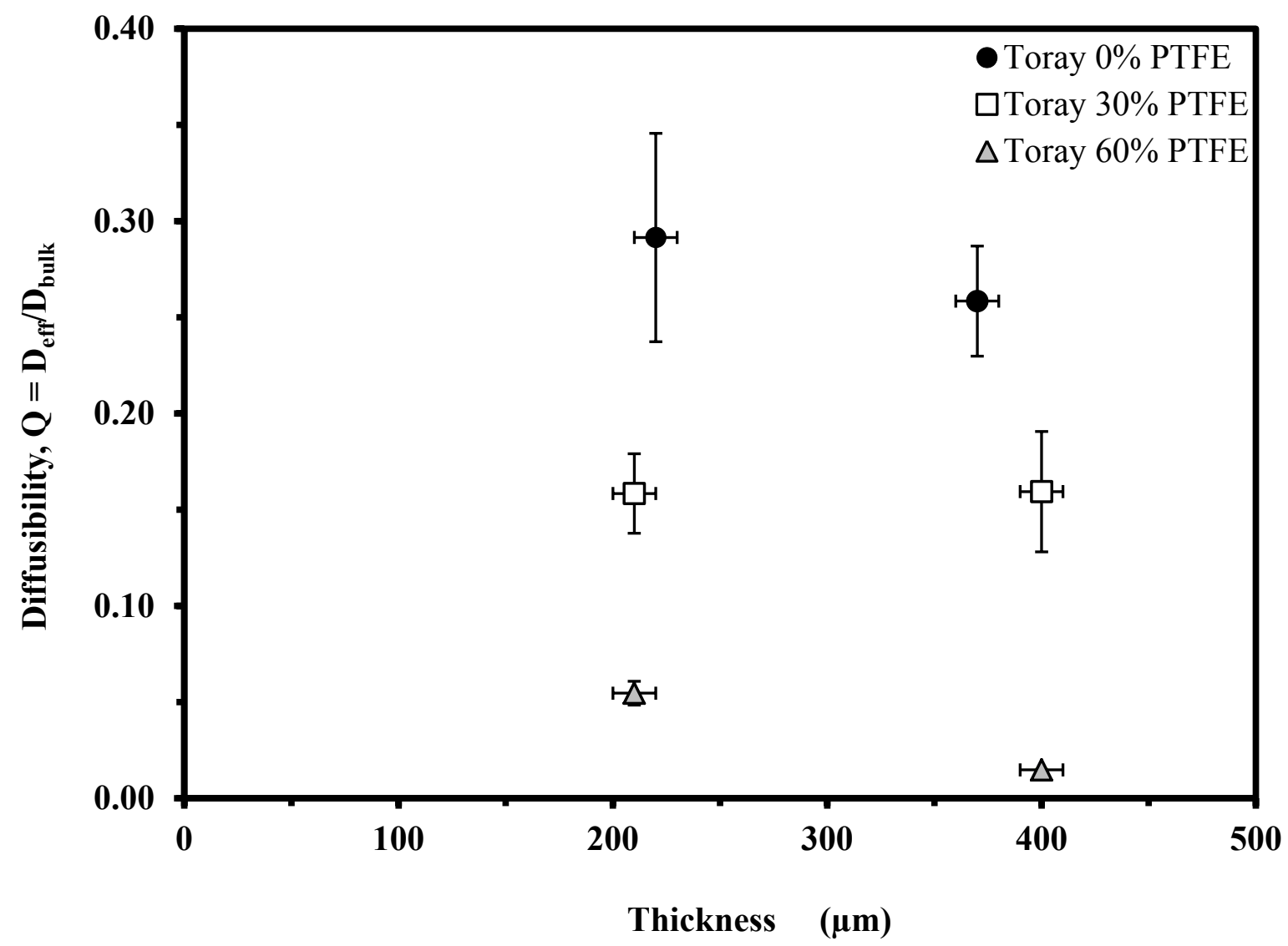

Figure 6.2 - Effect of the sample thickness on the measured diffusibility. Toray samples with the same PTFE loading but different thicknesses demonstrate no thickness effect. The $60 \%$ PTFE sample does not portray this because the average porosity between the two samples are about $10 \%$ apart, resulting in significant difference in the measured value.

\subsection{Effect of Microporous Layer (MPL)}

To determine the effective diffusion coefficient of the microporous layer, $D_{i}^{\text {eff,top }}$, the effective diffusion coefficient of the GDL substrate, $D_{i}^{\text {eff,bot }}$, on which the MPL is sintered to, is required. For this reason, only the SolviCore Type A series is used to in this analysis to calculate the effective diffusion coefficient of MPL because its bare substrate is available (SolviCore Type A, 5\% PTFE) such that the effective diffusion coefficient of the substrate, 
$D_{i}^{\text {eff,bot }}$ can be determined. The $D_{i}^{\text {eff,bot }}$ is equal to the $D_{i}^{\text {eff, } 1}$ calculated for the SolviCore Type A, 5\% PTFE sample.

To determine the thickness of the MPL coating $\left(\mathrm{L}_{2}-\mathrm{L}_{1}\right)$, a cross-sectional view of the SolviCore Type A, MPL sample is taken with scanning electron microscope (SEM) as shown in Figure 6.3. The samples are prepared by submersing in liquid nitrogen for two minutes until they become brittle and then they are fractured using straight edged tweezers. The image clearly shows that the coating thickness is not uniform due to penetration into the GDL substrate. Figure 6.4 illustrates the distribution of MPL thickness from the measurements obtained from SEM cross-sectional images from several SolviCore Type A, MPL samples. The total number of measurements is 61 , and the number of measurements that yield a particular MPL thickness is shown as "Frequency" in Figure 6.4. It is seen that the MPL coating thickness varies from $38.8 \mu \mathrm{m}$ to $112.2 \mu \mathrm{m}$ with a peak at $63.2 \mu \mathrm{m}$. The average thickness based on the thickness distribution shown in Figure 6.4 is calculated to be $66.4 \mu \mathrm{m}$. As shown in Table 5.4, SolviCore Type A GDL with 5\% PTFE loading has a nominal thickness of $210 \mu \mathrm{m}$, while SolviCore Type A GDL with MPL has a nominal thickness of $250 \mu \mathrm{m}$, but the measured mean MPL thickness is thicker than $40 \mu \mathrm{m}$ suggesting that MPL actually penetrates into the GDL substrate which has larger pores. 


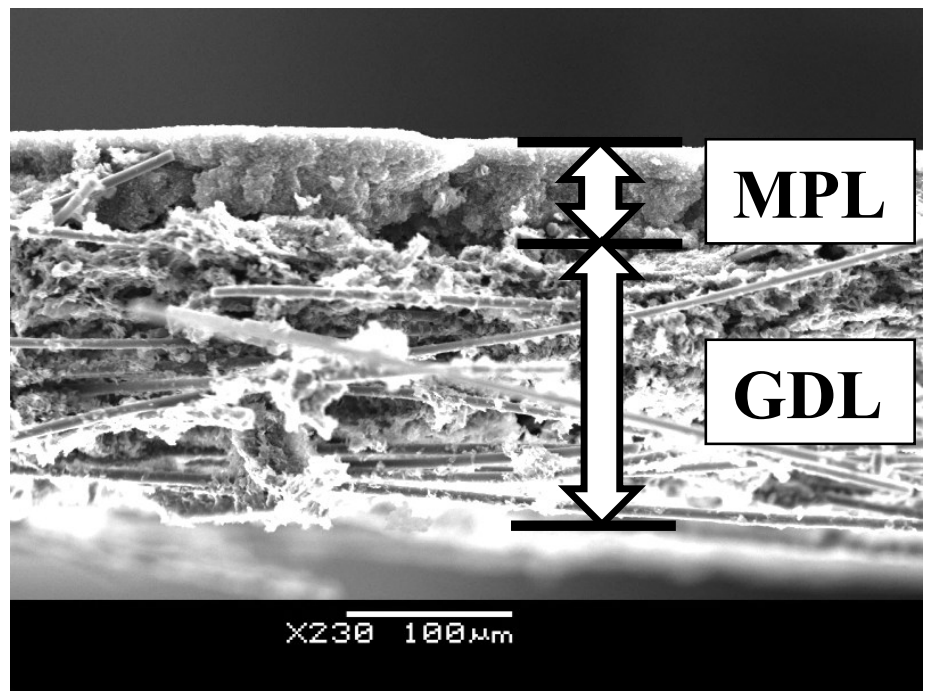

Figure 6.3 - Cross-sectional view of SolviCore Type A sample with microporous layer (MPL) prepared by free-fracture in liquid nitrogen.

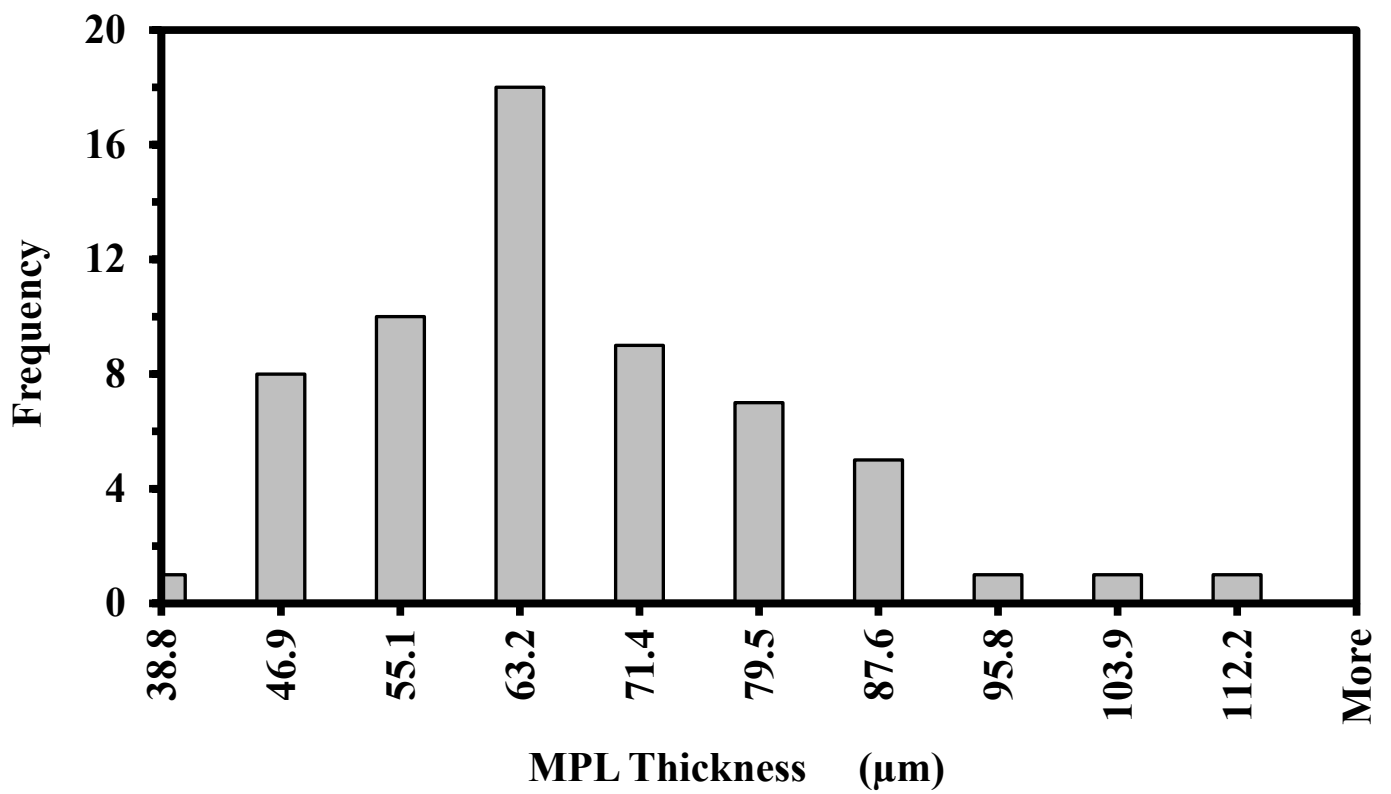

Figure 6.4 - Microporous layer (MPL) thickness distribution obtained from several SEM images for SolviCore Type A sample with MPL. The average thickness from the distribution is $66.4 \mu \mathrm{m}$. 
The microporous layer promotes a significant reduction in the diffusibility through the sample due to its restrictive pore structure, which penetrates into the GDL substrate. From examining the SolviCore Type A sample, the addition of MPL reduced the diffusibility and effective diffusion coefficient by around $42 \%$ when compared to its substrate (SolviCore Type A, 5\% PTFE), as shown in Table 5.4 and Table 6.1. The effective diffusion coefficient of the MPL coating only, $D_{i}^{\text {eff,top }}$, is about $21 \%$ of the effective diffusion coefficient of its GDL substrate, $D_{i}^{\text {eff,bot }}$, as shown in Table 6.1. The effective diffusion coefficient for the GDL with MPL is about $42 \%$ of the corresponding effective diffusion coefficient for the GDL substrate; or the MPL has reduced the sample's effective diffusion coefficient by about $58 \%$; indicating the significant impact of the MPL on the mass transport capability of the sample.

Table 6.1 - Comparison of the effective diffusion coefficient of the microporous layer to that of the GDL substrate (on which the coating was applied to) and to the effective diffusion coefficient of the GDL and MPL combined.

\begin{tabular}{|c|c|c|}
\hline $\begin{array}{c}\text { Effective Diffusion } \\
\text { Coefficient of Substrate } \\
\left(\times 10^{-6} \mathrm{~m}^{2} / \mathrm{s}\right)\end{array}$ & $\begin{array}{l}\text { Effective Diffusion } \\
\text { Coefficient of MPL } \\
\quad\left(\times 10^{-6} \mathrm{~m}^{2} / \mathrm{s}\right)\end{array}$ & $\begin{array}{c}\text { Effective Diffusion } \\
\text { Coefficient of GDL } \\
\text { with MPL }\left(\times 10^{-6} \mathrm{~m}^{2} / \mathrm{s}\right)\end{array}$ \\
\hline $7.33 \pm 1.5$ & $1.54 \pm 0.21$ & $3.07 \pm 0.22$ \\
\hline
\end{tabular}

From Figure 6.5, there are three outlying data points from this work which do not agree well with the available data and models. These three data points correspond to the three GDL samples with MPL that are measured in this work and their diffusion process behaves differently due to the presence of Knudsen effect. Currently, there are no conventional correlations or numerical models which account for the presence of MPL on GDL. 


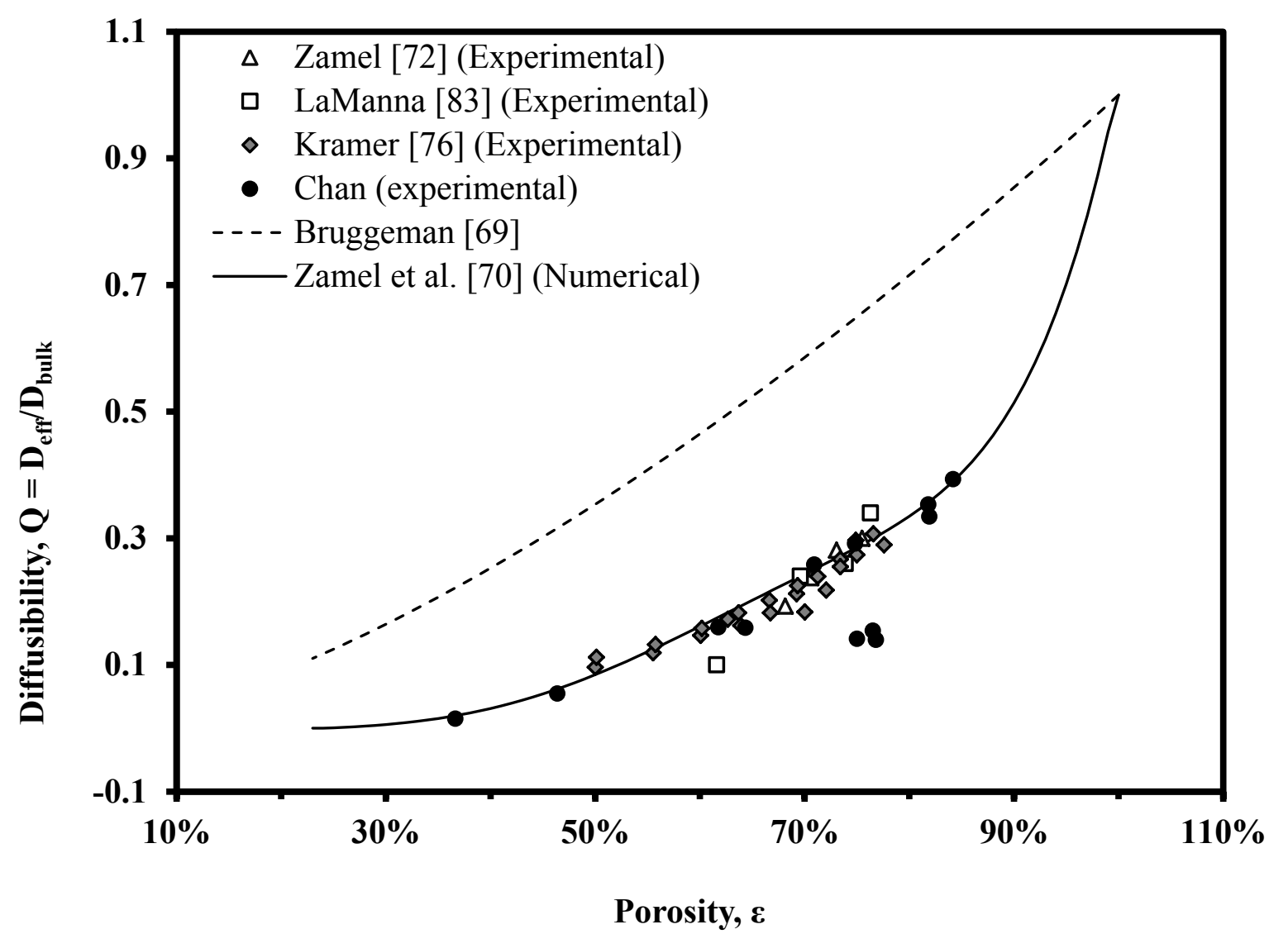

Figure 6.5 - Diffusivity vs. porosity for all samples measured in this work compared with the experimental work of others found in literature for through-plane diffusion. Also shown is the Bruggeman correlation and the numerical model by Zamel et al. [70].

The three outlying data points represent the three GDL samples which contain microporous layer (MPL).

To verify the presence of Knudsen effect, the Knudsen Number calculated from Eq. (3.12) is required to understand the diffusion regime occurring in the MPL. Under the room conditions during measurement of the SolviCore Type A, MPL sample, the average room pressure $(95.7 \mathrm{kPa})$ and room temperature $\left(22.4^{\circ} \mathrm{C}\right)$ yield a mean free path length, $\lambda$, of an oxygen molecule to be $104 \mathrm{~nm}$. As seen in Figure 6.6, the pore diameter in the SolviCore Type A, MPL sample obtained using Method of Standard Porosimetry (MSP) ranges from 
$7 \mathrm{~nm}$ to $133 \mathrm{~nm}$. It is seen that there are pores less than $7 \mathrm{~nm}$ in diameter, but the amount is insignificant and thus neglected. For this wide range of pore sizes in the MPL, both Knudsen and Fickian diffusion are expected to occur simultaneously.

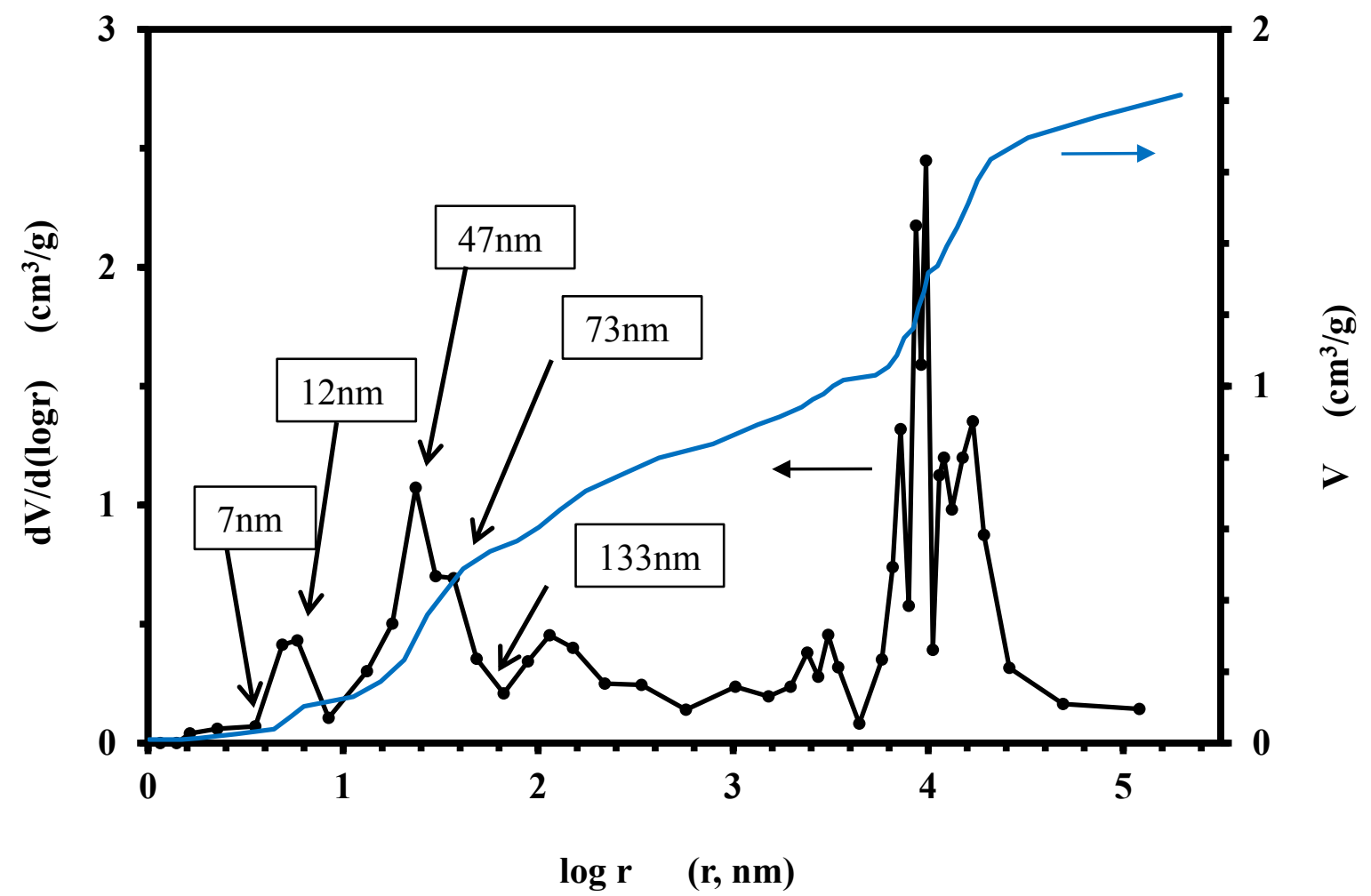

Figure 6.6 - Pore size distribution for SolviCore Type A sample with microporous layer (MPL) obtained using Method of Standard Porosimetry. The peaks on the left represent the pore diameters in the MPL which ranges from $7 \mathrm{~nm}$ to $133 \mathrm{~nm}$.

The effective diffusion coefficient of the MPL determined from the measurements, $D_{i}^{\text {eff,top }}$, represents the diffusion through all the pore space in the porous layer. Applying the model developed by $\mathrm{Mu}$ et al. [71], the $D^{\text {eff }}$ for a single cylindrical pore in Eq. (3.13) can be replaced with $D_{i}^{\text {eff,top }}$ (which is for the entire pore space) to determine the effective Knudsen diffusion coefficient, $D_{\mathrm{kn}}^{\text {eff }}$, or Knudsen effect through the entire pore space in the MPL. The Fickian diffusion coefficient, $D_{\text {Fickian }}$ in Eq. (3.13) must be replaced with the effective 
Fickian diffusion coefficient, $D_{\text {Fickian }}^{\text {eff }}$ because the entire pore space is now being considered. The $D_{\text {Fickian }}^{\text {eff }}$ can be determined from Zamel et al.'s numerical result [70] once the porosity of the MPL and $D_{i}^{\text {bulk }}$ due to Fickian diffusion is known.

The $D_{i}^{\text {bulk }}$ can be easily obtained from Eq. (4.1) for the given temperature and pressure recorded during the measurement.

For the porosity of the MPL, Gostick et al. [99] developed an expression given by:

$$
\varepsilon_{\mathrm{MPL}}=\left(1-\frac{V_{\text {pore }}^{\text {substrate }}}{V_{\text {pore }}^{\text {overall }}}\right) \varepsilon_{\text {overall }} \frac{t_{\text {overall }}}{t_{\mathrm{MPL}}}
$$

where $\varepsilon_{\mathrm{MPL}}$ and $t_{\mathrm{MPL}}$ are the porosity and thickness of the MPL respectively, $\varepsilon_{\text {overall }}$ and $t_{\text {overall }}$ are the average overall porosity and the overall thickness of the GDL with MPL respectively, $V_{\text {pore }}^{\text {substrate }}$ is the pore volume of the substrate, and $V_{\text {pore }}^{\text {overall }}$ is the overall pore volume of the GDL with MPL.

The pore volume of the substrate (SolviCore Type A, 5\% PTFE) and the pore volume of the overall sample (SolviCore Type A, MPL) are measured to be $0.0595 \mathrm{~cm}^{3}$ and 0.0769 $\mathrm{cm}^{3}$ respectively as a step in obtaining the porosity measurements presented in Table 5.1. As a result, the $\varepsilon_{\text {MPL }}$ is found to be around $64 \%$ and the associated $D_{\text {Fickian }}^{\text {eff }}$ that is calculated from Zamel et al.'s model yields $4.16 \times 10^{-6} \mathrm{~m}^{2} / \mathrm{s}$.

Table 6.2 shows that the Knudsen diffusion coefficient calculated from Eq. (3.13) accounts for about $80 \%$ of the effective diffusion coefficient through the GDL with MPL as shown in Table 6.1. The corresponding pore diameter in the MPL at which Knudsen effects contribute can be determined from Eq. (3.14) and is in the order of $16.6 \mathrm{~nm}$, as shown in Table 6.2. This is in reasonable agreement with the pore distribution of the MPL shown in Figure 6.6 because a portion of the pore sizes exist around $12 \mathrm{~nm}$ in diameter. Also this seems to suggest the Knudsen effect is dominated by the smaller pores in the MPL; while for the larger pores the Fickian diffusion still has considerable contribution to the overall mass transport. 
Table 6.2 - Knudsen diffusion coefficient calculated from Eq. (3.13) and the corresponding pore diameter calculated from Eq. (3.14).

\begin{tabular}{|c|c|c|c|}
\hline $\begin{array}{c}\text { Effective } \\
\text { Diffusion } \\
\text { Coefficient of } \\
\text { MPL }\left(\times 10^{-6} \mathrm{~m}^{2} / \mathrm{s}\right)\end{array}$ & 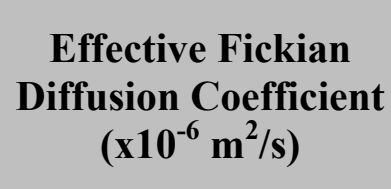 & $\begin{array}{c}\text { Effective Knudsen } \\
\text { Diffusion Coefficient } \\
\left(\times 10^{-6} \mathrm{~m}^{2} / \mathrm{s}\right)\end{array}$ & $\begin{array}{c}\text { Pore } \\
\text { diameter } \\
(\mathbf{n m})\end{array}$ \\
\hline $1.54 \pm 0.21$ & 4.16 & 2.45 & 16.6 \\
\hline
\end{tabular}

In the presence of the MPL, the thickness effect appears to contribute to diffusibility as shown in Figure 6.7, and this has also been suggested by LaManna et al. [83]. However, the reduction in diffusibility is more likely to be a function of the small pore sizes contributing to the degree of Knudsen effect. For small pore diameters $(\mathrm{Kn}>10)$, the molecule-wall collisions are expected to increase thus reducing the diffusibility. Increasing the diffusion length, or thickness of the MPL, would also increase the number of moleculewall collisions, hence reduce the effective mass transport. However, it might be expected that the small pore size would have a stronger effect than the length of the pores. 


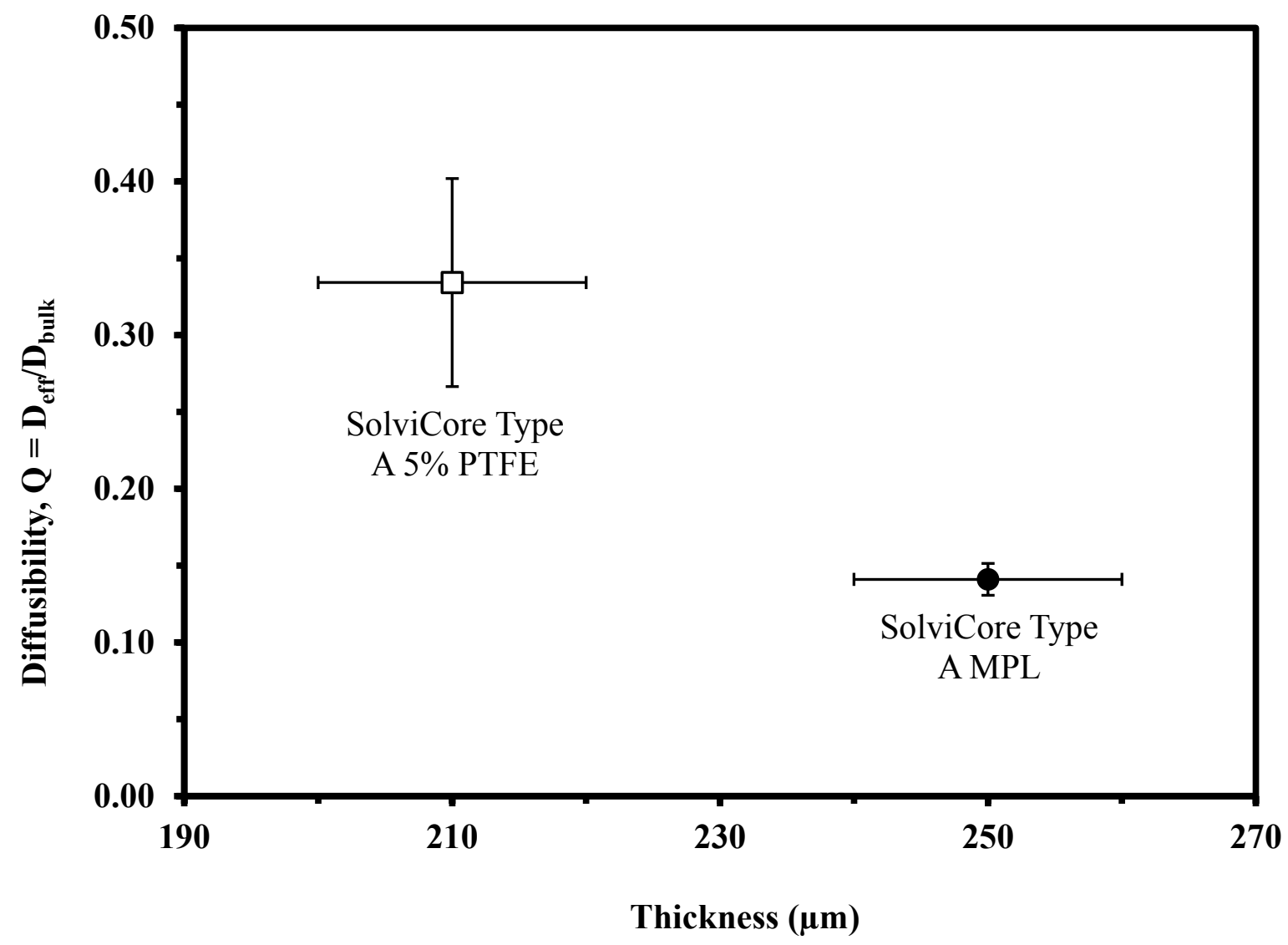

Figure 6.7 - Comparison of diffusibility and thickness for SolviCore Type A series. The microporous layer of the sample has an average thickness of $66.4 \mu \mathrm{m}$ rather than $40 \mu \mathrm{m}$ due to its penetration into the substrate. Thickness effect appears to play a role in the presence of a microporous layer.

The MPL thickness for the Solvicore Type A and B samples with MPL are very similar, $66.4 \mu \mathrm{m}$ for Type A determined earlier from the results as shown in Figure 6.6, and $60.7 \mu \mathrm{m}$ for Type B as shown in Figure 6.8. However, the MPL for Sigracet ${ }^{\circledR} 25$ DC is much thinner, about $38.4 \mu \mathrm{m}$ as shown in Figure 6.8. Having established the difference in MPL thickness, Figure 6.9 shows that the diffusibility of the three GDL samples with MPL measured in this study are within the acceptable limits of each other; meaning that when comparing samples with MPL, the thickness of the layer has no apparent and significant 
effect, although SolviCore Type A, MPL has a slightly thicker MPL, and correspondingly a slightly smaller measured diffusibility.
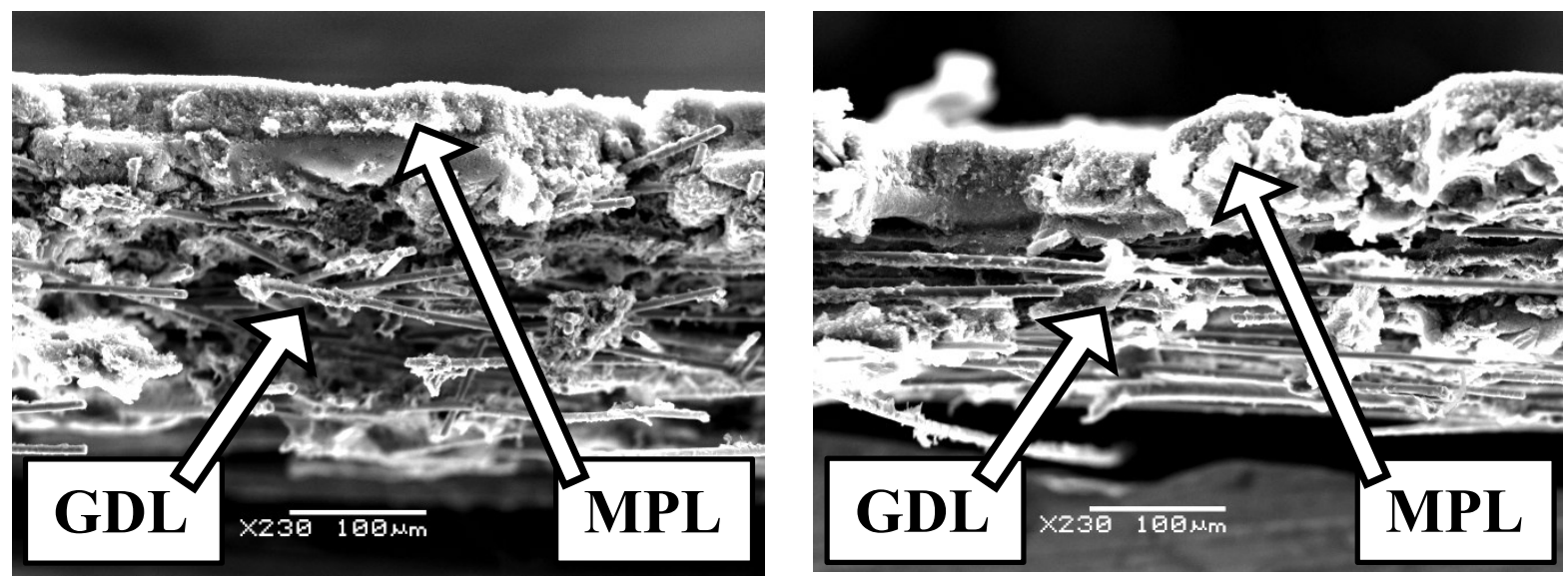

Figure 6.8 - SEM cross section of samples (prepared by freeze fracture in liquid nitrogen) containing microporous layer to illustrate a difference in layer thickness. Left: $38.4 \mu \mathrm{m}$ average (Sigracet ${ }^{\circledR} 25 \mathrm{DC}$ ), Right: $60.7 \mu \mathrm{m}$ average (SolviCore Type B, MPL). 


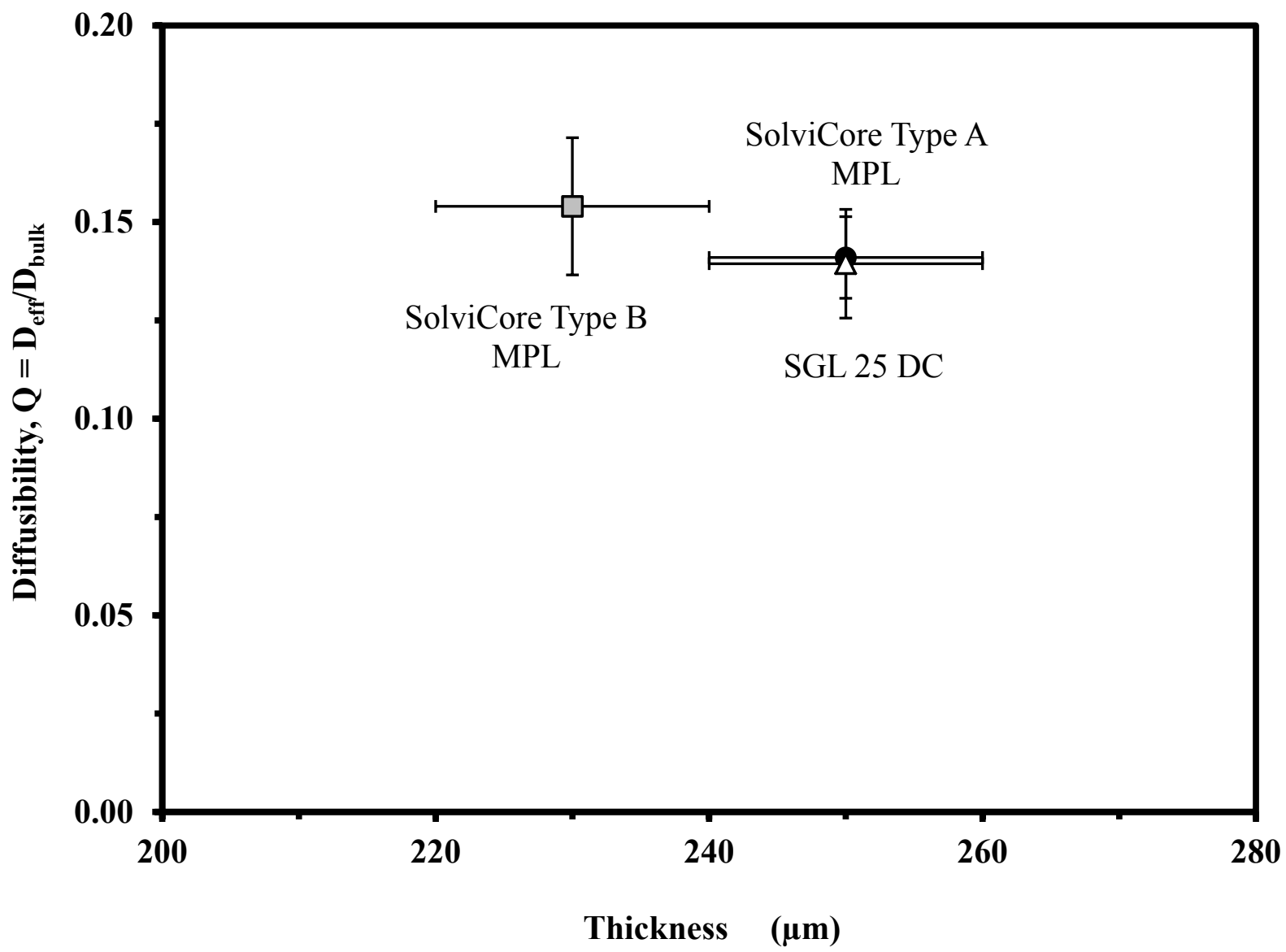

Figure 6.9 - Comparison of diffusibility and thickness for samples with microporous layer. Thickness does not have an apparent and significant effect when samples with microporous layer are compared with each other.

\subsection{Comparison of Results to Literature}

The experimentally determined values for diffusivity in the through-plane direction are compared to values obtained by Kramer et al. [76], Zamel et al. [72] and LaManna et al. [83] in Figure 6.5. Good agreement between the current work and those in literature demonstrate that the viability of the present apparatus and measurement methods for the intended measurements in this study. 
The numerical result from Zamel et al. [70] is also plotted along with the experimental results in Figure 6.5 and it is in good agreement with the current work. It is obvious that these experimental results do not agree well with the conventional correlations such as Bruggeman for the effective diffusion coefficient. This means that, as Zamel et al. [72] and LaManna et al. [83] have already realized, the conventional correlations tend to over-predict the effective diffusion coefficient for mass transport. The results obtained in this work further validates Zamel et al.'s model by providing experimental data in the porosity region of $\varepsilon<50 \%$ and $\varepsilon>80 \%$ that are unavailable in literature. It can be observed that three distinct data points from the present study do not fit to the numerical result of Zamel et al. and the reason is because they contain microporous layer. Zamel et al.'s numerical model does not take into account the presence of MPL and thus it requires further analysis as shown in Section 6.3. 


\section{Chapter 7}

\section{Conclusions}

A modified Loschmidt cell with an oxygen-nitrogen mixture is used to measure the effective through-plane diffusion coefficient of gas diffusion layer (GDL) in PEM fuel cells with total equipment error no greater than $5.2 \%$. The measurements are performed at room temperature and pressure, $22^{\circ} \mathrm{C} \pm 1{ }^{\circ} \mathrm{C}$ and $94-97 \mathrm{kPa}$, respectively, and the results are presented within $95 \%$ confidence level. Commercially available GDLs that are tested include Toray, SolviCore and SGL Sigracet ${ }^{\circledR}$ at various PTFE loadings, thicknesses and with or without the addition of microporous layer (MPL). The following summarizes the conclusions drawn from this work:

- Increasing the PTFE content decreases the average porosity of the GDL by covering areas previously available to diffusion, thus reducing the effective diffusion coefficient of the GDL;

- For GDL samples without MPL, thickness does not contribute any effect to the effective diffusion coefficient as long as the average porosity remains relatively constant;

- The MPL coating alone on the SolviCore Type A series is found to be $21 \%$ of the effective diffusion coefficient of its GDL substrate;

- The Knudsen diffusion coefficient accounts for about $80 \%$ of the effective diffusion coefficient of the GDL with MPL;

- Conventional Bruggeman correlation for the effective diffusion coefficient in porous medium over-predicts mass diffusion process, Zamel et al.'s correlation is adequate for diffusion through the GDL without the MPL, but over-predicts for the GDLs with MPL. 


\section{References}

[1] Hubbert, M.K., Nuclear Energy and the Fossil Fuel, Drilling and Production Practice 56 (1956) 07-25.

[2] Pimentel, D., Hurd, L.E., Bellotti, A.C., Forster, M.J., Oka, I.N., Sholes, O.D., Whitman, R.J. Food Production and the Energy Crisis. Science 182 (1973) 443-449.

[3] Kerr, R.A., The Next Oil Crisis Looms Large - and Perhaps Close. The American Association for the Advancement of Sciences 281 (1998) 1128-1131.

[4] Bently, R.W. Global oil \& gas depletion: an overview. Energy Policy 30 (2002) 189205.

[5] Pukrushpan, J.T., "Control of Fuel Cell Power Systems”, Springer, 2004

[6] PEM Fuel Cells, Smithsonian Institution, 2004

$<$ http://americanhistory.si.edu/fuelcells/pem/pemmain.htm> (March 18, 2010)

[7] Higier, A., Liu, H. Optimization of PEM fuel cell flow field via local current density measurement. International Journal of Hydrogen Energy 35 (2010) 2144-2150.

[8] Friedmann, R., Nguyen T.V. Optimization of the Microstructure of the Cathode Catalyst Layer of PEM FUEL CELL for Two-Phase Flow. Journal of The Electrochemical Society157 (2010) B260-B265.

[9] Yuan, W., Tang, Y., Pan, M., Li, Z., Tang, B. Model prediction of effects of operating parameters on proton exchange membrane fuel cell performance. Renewable Energy 35 (2010) 656-666.

[10] Ang, S.M.C., Brett, D.J.L., Fraga, E.S. A multi-objective 65ptimization model for a general polymer electrolyte membrane fuel cell system. Journal of Power Sources 195 (2010) 2754-2763.

[11] Li, Q., Jensen, J.O., Savinell, R.F., Bjerrum, N.J. High temperature proton exchange membranes based on polybenzimidazoles for fuel cells. Progress in Polymer Science 34 (2009) 449-477.

[12] Outeiro, M.T., Chibante, R., Carvalho, A.S., de Almeida, A.T. A parameter optimized model of a proton exchange membrane fuel cell including temperature effects. Journal of Power Sources 185 (2008) 952-960. 
[13] Fowler, M.W., Mann, R.F., Amphlett, J.C., Peppley, B.A., Roberge, P.R. Incorporation of voltage degradation into a generalized steady state electrochemical model for a PEM fuel cell. Journal of Power Sources 106 (2002) 274-283.

[14] Amphlett, J.C., Mann, R.F., Peppley, B.A., Roberge, P.R., Rodrigues, A. A model predicting transient response of proton exchange membrane fuel cells. Journal of Power Sources 61 No. 1-2 (1996) 183-188.

[15] Das, P.K. Li, X., Liu, Z.S. Analysis of liquid water transport in cathode catalyst layer of PEM fuel cells. International Journal of Hydrogen Energy 35 (2010) 2403-2416.

[16] Baschuk, J.J., Li, X. A comprehensive, consistent and systematic mathematical model of PEM fuel cells. Applied Energy 86 (2009) 181-193.

[17] Burlatsky, S.F., Atrazhev, V.V., Gummalla, M., Condit, D.A., Fuquiang, L. The impact of thermal conductivity and diffusion rates on water 66apour transport through gas diffusion layers. Journal of Power Sources 190 (2009) 485-492.

[18] Yu, L.J., Ren, G.P., Qin, M.J., Jiang, X.M. Transport mechanisms and performance simulations of a PEM fuel cell with interdigitated flow field. Renewable Energy 34 (2009) 530-543.

[19] Bazylak, A. Liquid water visualization in PEM fuel cells: A review. International Journal of Hydrogen Energy 34 (2009) 3845-3857.

[20] Siegel, C. Review of computational heat and mass transfer modeling in polymerelectrolyte-membrane (PEM) fuel cells. Energy 33 (2008) 1331-1352.

[21] Niu, X., Munekata, T., Hyodo, S.A., Suga, K. An investigation of water-gas transport processes in the gas diffusion layer of a PEM fuel cell by multiphase multiplerelaxation-time lattice Boltzmann model. Journal of Power Sources 172 (2007) 542552.

[22] Wenquan, T., Xunliang L., Zengyao, L., Yaling, H. Three-dimensional transport model of PEM fuel cell with straight flow channels. Journal of Power Sources 158 (2006) 25-35.

[23] Mingruo, H., Zhu, X., Wang, M., Zhu, X., Yu, L. Three dimensional, two phase flow mathematical model for PEM fuel cell: Part II. Analysis and discussion of the internal transport mechanisms. Energy Conversion and Management 45 (2004) 1883-1916. 
[24] Shi, Z., Wang, X., Guessous, A. Effect of Compression on the Water Management of a Proton Exchange Membrane Fuel Cell With Different Gas Diffusion Layers. Journal of Fuel Cell Science and Technology 7 (2010) 1-7.

[25] Cindrella, L., Kannan, A.M., Lin, J.F., Saminathan, K., Ho, Y., Lin, C.W., Wertz, J. Gas diffusion layer for proton exchange membrane fuel cells-A review. Journal of Power Sources 194 (2009) 146-160.

[26] Wang, Y., Wang, C.Y., Chen, K.S. Elucidating differences between carbon paper and carbon cloth in polymer electrolyte fuel cells, Electrochimica Acta 52 (2007) 39653975.

[27] Yoshizawa, K., Ikezoe, K., Tasaki, Y., Kramer, D., Lehmann, E.H., Scherer, G.G. Analysis of gas diffusion layer and flow-field design in a PEMFC using neutron radiography. Journal of Electrochemical Society 155 (2008) B223-B227.

[28] Lee, H.-K., Park, J.-H., Kim, D.-Y., Lee, T.-H. A study on the characteristics of the diffusion layer thickness and porosity of the PEMFC. Journal of Power Sources 131 (2004) 200-206.

[29] Williams, M.V., Begg, E., Bonville, L., Kunz, H.R., Fenton, J.M. Characterization of gas diffusion layers for PEMFC. Journal of the Electrochemical Society 151 (2004) A1173-A1180.

[30] Kong, C.S., Kim, D.-Y., Lee, H.-K., Shul, Y.-G., Lee, T.-H. Influence of pore-size distribution of diffusion layer on mass-transport problems of proton exchange membrane fuel cells. Journal of Power Sources 108 (2002) 185-191.

[31] Zhan, Z., Xiao, J., Li, D., Pan, M., Yuan, R. Effects of porosity distribution variation on the liquid water flux through gas diffusion layers of PEM fuel cells. Journal of Power Sources 160 (2006) 1041-1048.

[32] Park, S., Lee, J.-W., Popov, B.N. Effect of carbon loading in microporous layer on PEM fuel cell performance. Journal of Power Sources 163 (2006) 357-363.

[33] Tang, H., Wang, S., Pan, M., Yuan, R. Porosity-graded micro-porous layers for polymer electrolyte membrane fuel cells. Journal of Power Sources 166 (2007) 4146.

[34] Park, G.-G., Sohn, Y.-J., Yang, T.-H., Yoon, Y.-G., Lee, W.-Y., Kim, C.-S. Effect of PTFE contents in the gas diffusion media on the performance of PEMFC. Journal of Power Sources 131 (2004) 182-187. 
[35] Weber, A.Z., Newman, J. Effects of microporous layers in polymer electrolyte fuel cells. Journal of the Electrochemical Society 152 (2005) A677-A688.

[36] Pasaogullari, U., Wang, C.-Y., Chen, K.S. Two-phase transport in polymer electrolyte fuel cells with bilayer cathode gas diffusion media. Journal of the Electrochemical Society 152 (2005) A1574-A1582.

[37] Atiyeh, H.K., Karan, K., Peppley, B., Phoenix, A., Halliop, E., Pharoah, J. Experimental investigation of the role of a microporous layer on the water transport and performance of a PEM fuel cell. Journal of Power Sources 170 (2007) 111-121.

[38] Ramasamy, R.P., Kumbur, E.C., Mench, M.M., Liu, W., Moore, D., Murthy, M. Investigation of macro- and micro-porous layer interaction in polymer electrolyte fuel cells. International Journal of Hydrogen Energy 33(2008) 3351-3367.

[39] Zhigang, Q., Kaufman, A. Improvement of water management by a microporous sublayer for PEM fuel cells. Journal of Power Sources 109 (2002) 38-46.

[40] Gostick, J., Ioannidis, M., Fowler, M., Pritzker, M. On the role of the microporous layer in PEM FUEL CELL operation. Electrochemistry Communications 11 (2009) 576-579.

[41] Lin, G., Van Nguyen, T. Effect of thickness and hydrophobic polymer content of the gas diffusion layer on electrode flooding level in a PEMFC. Journal of the Electrochemical Society 152 (2005) A1942-A1948.

[42] Park, S., Lee, J.-W., Popov, B.N. Effect of PTFE content in microporous layer on water management in PEM fuel cells. Journal of Power Sources 177 (2008) 457-463.

[43] Jordan, L.R., Shukla, A.K., Behrsing, T., Avery, N.R., Muddle, B.C., Forsyth, M. Effect of diffusion-layer morphology on the performance of polymer electrolyte fuel cells operating at atmospheric pressure. Journal of Power Sources 86 (2000) 250254.

[44] Pasaogullari, U., Wang, C.-Y., Two-phase transport and the role of micro-porous layer in polymer electrolyte fuel cells. Electrochimica Acta 49 (2004) 4359-4369.

[45] Giorgi, L., Antolini, E., Pozio, A., Passalacqua, E. Influence of the PTFE content in the diffusion layer of low-Pt loading electrodes for polymer electrolyte fuel cells. Electrochemica Acta 43 (1998) 3675-3680. 
[46] Lobato, J., Cañizares, P., Rodrigo, M.A., Ruiz-López, C., Linares, J.J. Influence of the Teflon loading in the gas diffusion layer of PBI-based PEM fuel cells. Journal of Applied Electrochemistry 38 (2008) 793-802.

[47] Escribano, S., Blachot, J.-F., Ethève, J., Morin, A., Mosdale, R. Characterization of PEMFCs gas diffusion layers properties. Journal of Power Sources 156 (2006) 8-13.

[48] Lee, W.K., Ho, C.H., Van Zee, J.W., Murthy, M. The effects of compression and gas diffusion layers on the performance of a PEM fuel cell. Journal of Power Sources 84 (1999) 45-51.

[49] Bazylak, A., Sinton, D., Liu, Z.-S., Djilali, N. Effect of compression on liquid water transport and microstructure of PEMFC gas diffusion layers. Journal of Power Sources 163 (2007) 784-792.

[50] Zhou, P., Wu, C.W. Numerical study on the compression effect of gas diffusion layer on PEMFC performance. Journal of Power Sources 170 (2007) 93-100.

[51] Roshandel, R., Farhanieh, B., Saievar-Iranizad, E. The effects of porosity distribution variation on PEM fuel cell performance. Renewable Energy 30 (2005) 1557-1572.

[52] Ge, J., Higier, A., Liu, H. Effect of gas diffusion layer compression on PEM fuel cell performance. Journal of Power Sources 159 (2006) 922-927.

[53] Sadeghi, E., Djilali, N., Bahrami, M. Effective Thermal Conductivity and Thermal Contact Resistance of Gas Diffusion Layers in Proton Exchange Membrane Fuel Cells. Part 1: Effect of Compressive Load. Journal of Power Sources 196 (2011) 246254.

[54] Burheim, O., Vie, P.J.S., Pharaoh, J.G., Kjelstrup, S. Ex Situ Measurements of Through-plane Thermal Conductivities in a Polymer Electrolyte Fuel Cell. Journal of Power Sources 195 (2010) 249-256.

[55] Karimi, G., Li, X., Teertstra, P. Measurement of Through-plane Effective Thermal Conductivity and Contact Resistance in PEM Fuel Cell Diffusion Media. Electrochimica Acta 55 (2010) 1619-1625.

[56] Nitta, I., Himanen, O., Mikkola, M. Thermal Conductivity and Contact Resistance of Compressed Gas Diffusion Layer of PEM Fuel Cell. Fuel Cells 8 (2008) 111-119.

[57] Kestin, J., and Wakeham, W.A. Transport Properties of Fluids: Thermal Conductivity, Viscosity, and Diffusion Coefficient, CINDAS Data Series on Material Properties Volume I-1, Purdue Research Foundation, 1988. 
[58] Mehrer, H., Stolwijk, N.A. Heroes and Highlights in the History of Diffusion. Diffusion-fundamentals.org 11 (2009) 1-32.

[59] Li, Z., Dong, M. Experimental Study of Carbon Dioxide Diffusion in Oil-Saturated Porous Media under Reservoir Conditions. Industrial Engineering Chemical Research 48 (2009) 9307-9317.

[60] Kröcher, O., Elsener, M., Votsmeier, M. Determination of Effective Diffusion Coefficients through the Walls of Coated Diesel Particulate Filters. Industrial Engineering Chemical Research 48 (2009) 10746-10750.

[61] Das, P.K., Li, X., Liu, Z.S. Effective transport coefficients in PEM fuel cell catalyst and gas diffusion layers: Beyond Bruggeman approximation. Applied Energy 87 (2010) 2785-2796.

[62] Mezedur M.M., Kaviany, M., Moore, W. Effect of Pore Structure, Randomness and Size on Effective Mass Diffusivity. AIChE Journal 48 (2002) 15-24.

[63] Nam, J.H., Kaviany, M. Effective diffusivity and water-saturation distribution in single- and two-layer PEM FUEL CELL diffusion medium. International Journal of Heat and Mass Transfer 46 (2003) 4595-4611.

[64] Tomadakis, M.M., Sotirchos S.V. Ordinary and transition regime diffusion in random fiber structures. AIChE Journal 39 (2004) 397-412.

[65] Maxwell, J.C. A treatise on electricity and magnetism, Vol. 1, $3^{\text {rd }}$ Edn. Dover, New York, 1954.

[66] Rayleigh, L. On the influence of obstacles arranged in rectangular order upon the properties of a medium. Phil Mag 34 (1892) 481-503.

[67] Weissberg, H.L. Effective diffusion coefficients in porous media. Journal of Applied Physics 34 (1963) 297-303.

[68] Neale, G. H., Nader, W. K. Prediction of Transport Processes within Porous Media: Diffusive Flow Processes within an Homogeneous Swarm of Spherical Particles. AIChE J. 19 (1973) 112-119.

[69] Bruggeman, D.A.G. Berechnung verschiedener physicalischer konstaten von heterogenen substanzen. Annals of Physics 24 (1935) 636-664. 
[70] Zamel, N., Li, X., Shen, J., Correlation for the Effective Gas Diffusion Coefficient in Carbon Paper Diffusion Media, Energy Fuels, 23 (2009) 6070-6078.

[71] Mu, D., Liu, Z., Huang, C., Djilali, N. Determination of the effective diffusion coefficient in porous media including Knudsen effects. Microfluid Nanofluid 4 (2008) 257-260.

[72] Zamel, N., Astrath, N.G.C., Li, X., Shen, J., Zhou, J., Astrath, F.B.G., Wang, H., Liu, Z. Experimental measurements of effective diffusion coefficient of oxygen-nitrogen mixture in PEM fuel cell diffusion media. Chemical Engineering Science 65 (2010) 931-937.

[73] Baker, D., Wieser, C., Neyerlin, K.C., Murphy, M.W. The Use of Limiting Current to Determine Transport Resistance in PEM Fuel Cells. ECS Transactions 3 (2006) 989999.

[74] Beuscher, U., Experimental Method to Determine the Mass Transport Resistance of a Polymer Electrolyte Fuel Cell. Journal of The Electrochemical Society 153 (2006) A1788-A1793.

[75] Stumper, J., Löhr, M., Hamada, S., Diagnostic tools for liquid water in PEM fuel cells. Journal of Power Sources 143 (2005) 150-157.

[76] Kramer, D., Freunberger S.A., Flükiger, R., Schneider I.A., Wokaun, A., Büchi, F.N., Scherer, G.G. Electrochemical diffusimetry of fuel cell gas diffusion layers. Journal of Electroanalytical Chemistry 612 (2008) 63-77.

[77] Gostick, J., Fowler, M., Pritzker, M., Ioannidis, M., Behra, L., In-plane and throughplane permeability of carbon fiber electrode backing layers. Journal of Power Sources 162 (2006) 228-238.

[78] Flückiger,R., Freunberger, S., Kramer, D., Wokaun, A., Scherer, G., Büchi, F., Anisotropic, effective diffusivity of porous gas diffusion layer materials for PEFC. Electrochemica Acta 54 (2008) 551-559.

[79] Astrath, N., Shen, J., Song, D., Rohling, J., Astrath, F., Zhou, J., Navessin, T., Liu, Z., Gu, C., Zhao, X., The Effect of Relative Humidity on Binary Gas Diffusion. Journal of Physical Chemistry B 113 (2009) 8369-8374.

[80] Marrero, T.R. and Mason, E.A., Gaseous Diffusion Coefficients, Journal of Physical Chemistry Reference Data, Vol. 1, No. 1, 1972. 
[81] Quick, C., Ritzinger, D., Lehnert, W., Hartnig, C., Characterization of water transport in gas diffusion media. Journal of Power Sources 190 (2009) 110-120.

[82] Casalegno, A., Colombo, L., Galbiati, S., Marchesi, R., Quantitative characterization of water transport and flooding in the diffusion layers of polymer electrolyte fuel cells. Journal of Power Sources 195 (2010) 4143-4148.

[83] LaManna, J., Kandlikar, S., Determination of effective water vapour diffusion coefficient in PEM fuel cell gas diffusion layers. International Journal of Hydrogen Energy 36 (2011) 5021-5029.

[84] Crank, J., The Mathematics of Diffusion, Second Ed. Oxford University Press, New York. 1975.

[85] Kast, W., Hohenthanner, C., Mass transfer within the gas-phase of porous media. International Journal of Heat and Mass Transfer 43 (2000) 807-823.

[86] Pinazza, O., Spiga, M. Friction factor at low Knudsen number for the duct with sineshaped cross-section. International Journal of Heat and Fluid Flow 24 (2003) 236241.

[87] Mason, E.A., Malinauskas, A.P. Gases transport in porous media: the dusty-gas model. Elsevier, Amsterdam, 1983.

[88] Mason, E.A., Malinauskas, A.P., Evans, R.B. III. Flow and diffusion of gases in porous media. The Journal of Chemical Physics 46 (1967) 3199-3216.

[89] Pollard, W.G., Present, R.D. On gaseous self-diffusion in long capillary tubes. Physical Review 73 (1948) 752-774.

[90] Cunningham, R., Williams, R., Diffusion in gases and porous media. Plenum, New York. 1980.

[91] Rohling, J., Shen, J., Wang, C., Zhou, J., Gu, C., Determination of binary diffusion coefficients of gases using photothermal deflection technique. Applied Physics B 87 (2007) 355-362.

[92] Rohling, J., Shen, J., Zhou, J., Gu, C., Application of the diffraction theory for photothermal deflection to the measurement of the temperature coefficient of the refractive index of a binary gas mixture. Journal of Applied Physics 99 (2006) 103107. 
[93] Sensor Coating Formulation, Ocean Optics Inc., 2010 $<$ http://www.oceanoptics.com/products/sensorcoatings.asp > (March 23, 2011)

[94] Boyd, C., Stein, N., Steingrimsson, V., Rumpel, W., An Interferometric Method of Determining Diffusion Coefficients in Gaseous Systems. The Journal of Chemical Physics 19 (1951) 548-553.

[95] Ljunggren, S., The Diffusion of uranium hexafluoride in some other Gases, Arkiv för kemi, 24 (1965) 1-46.

[96] Fiber Optic Oxygen Sensor Frequently Asked Questions, Ocean Optics Inc., 2011 $<$ http://www.oceanoptics.com/Products/sensorfaqs.asp > (July 02, 2011)

[97] Gostick, J., Multiphase Mass Transfer and Capillary Properties of Gas Diffusion Layers for Polymer Electrolyte Membrane Fuel Cells. PhD Thesis. University of Waterloo, Waterloo, ON. 2008.

[98] Taylor, J.R., An introduction to error analysis: the study of uncertainties in physical measurements, Second Edition. University Science Books, 1997.

[99] Gostick, J., Fowler, M., Ioannidis, M., Pritzker, M., Volfkovich, Y.M., Sakars, A. Capillary pressure and hydrophilic porosity in gas diffusion layers for polymer electrolyte fuel cells. Journal of Power Sources 156 (2006) 375-387. 


\section{Appendix A \\ Schematic Drawings for Diffusion Cell}




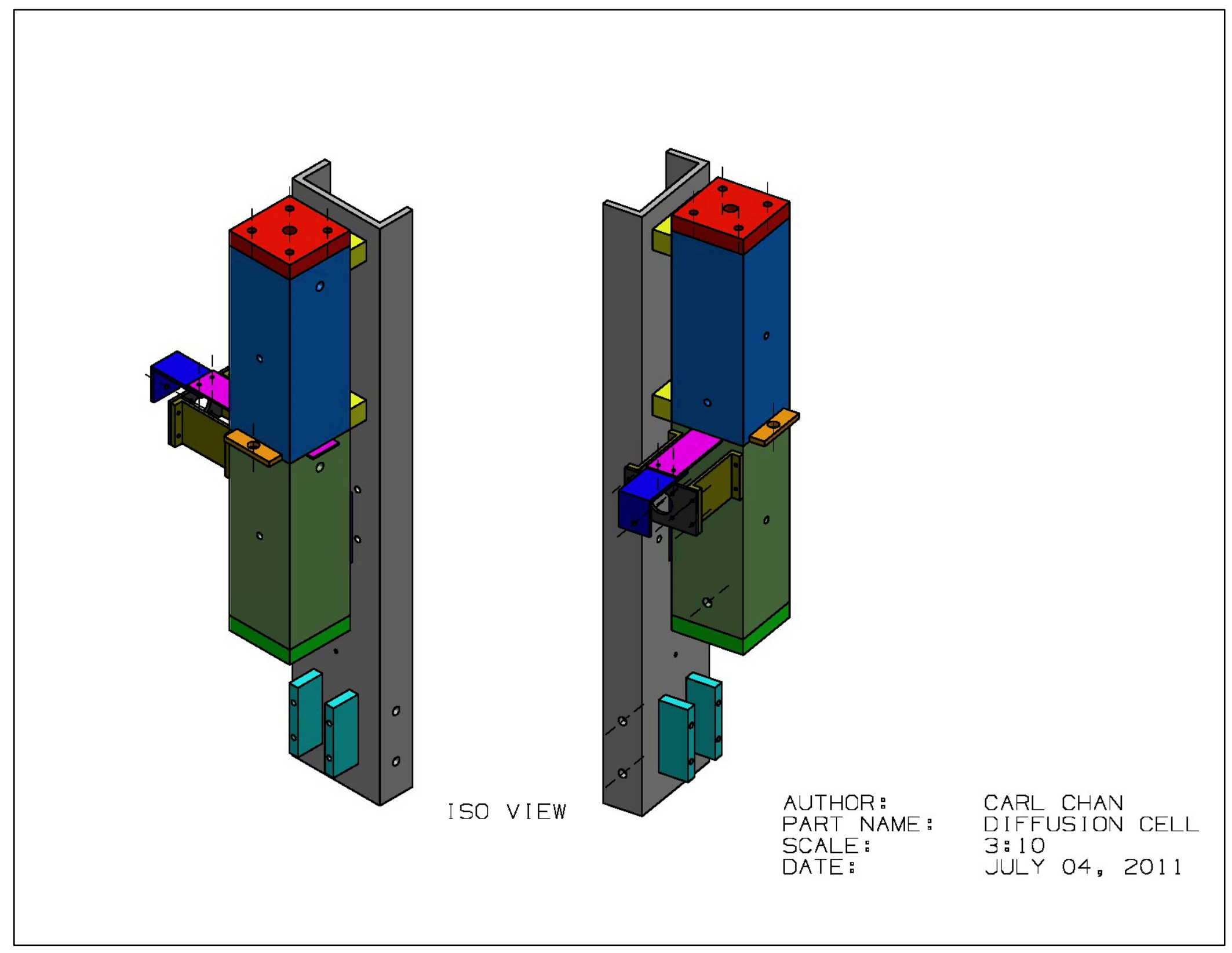




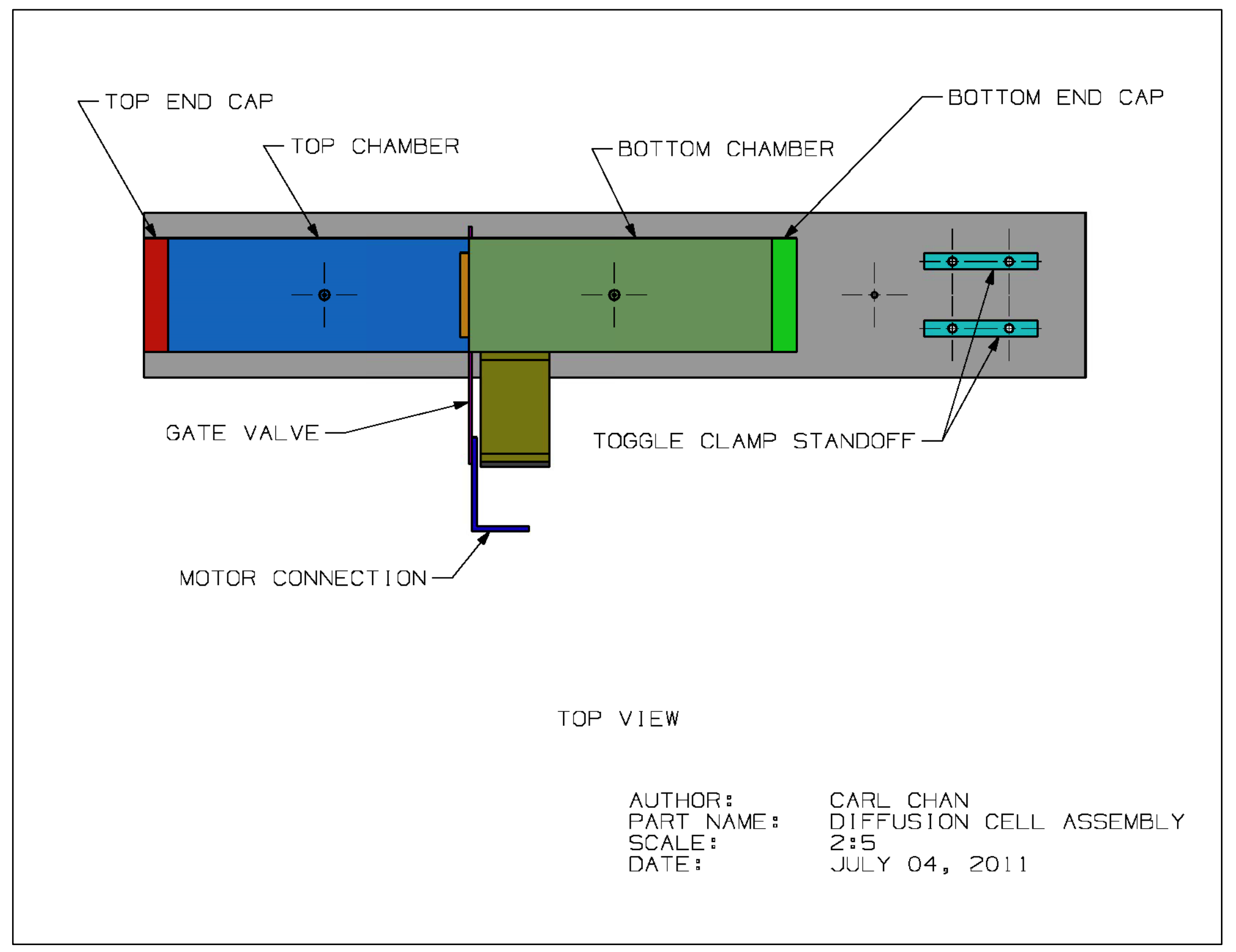




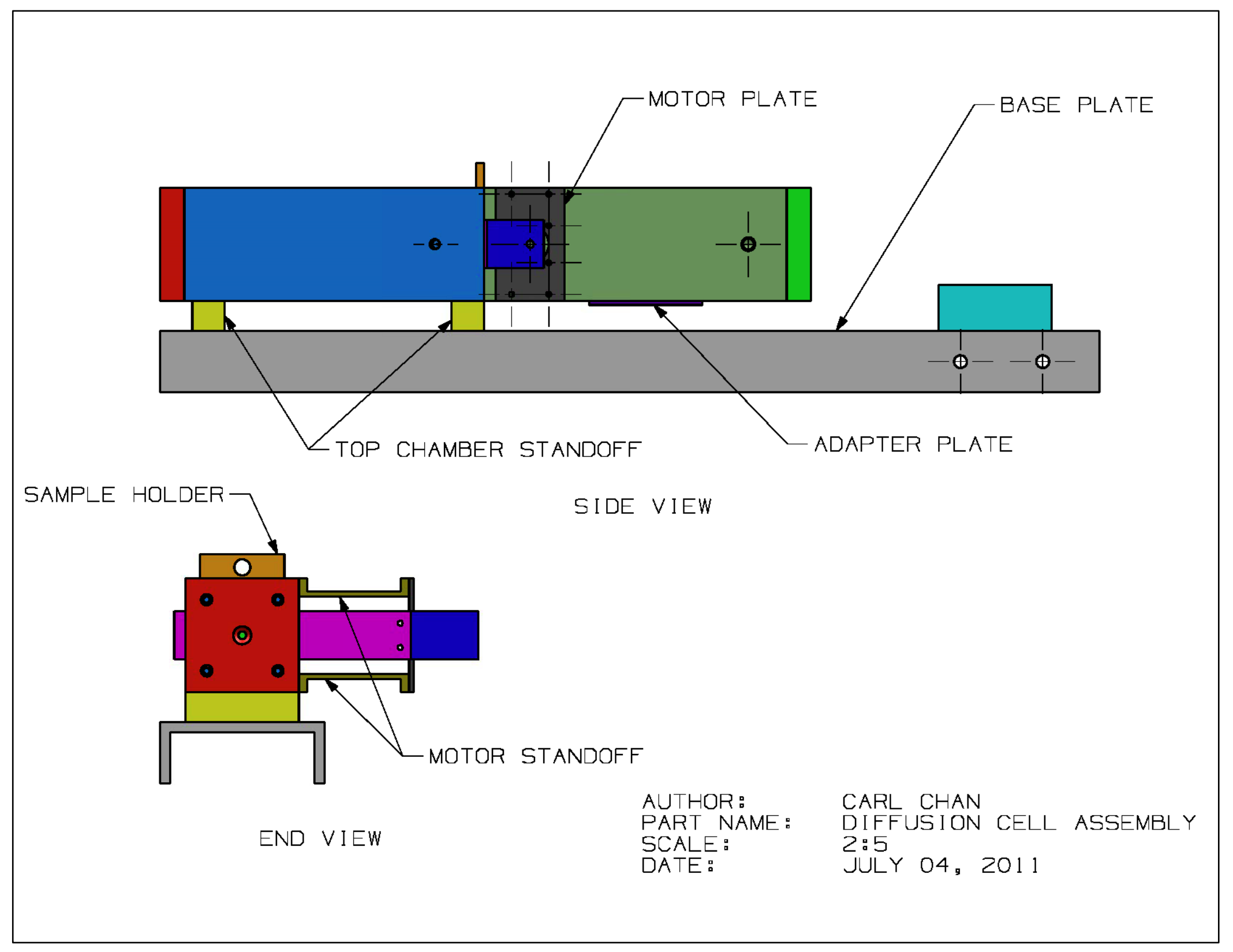




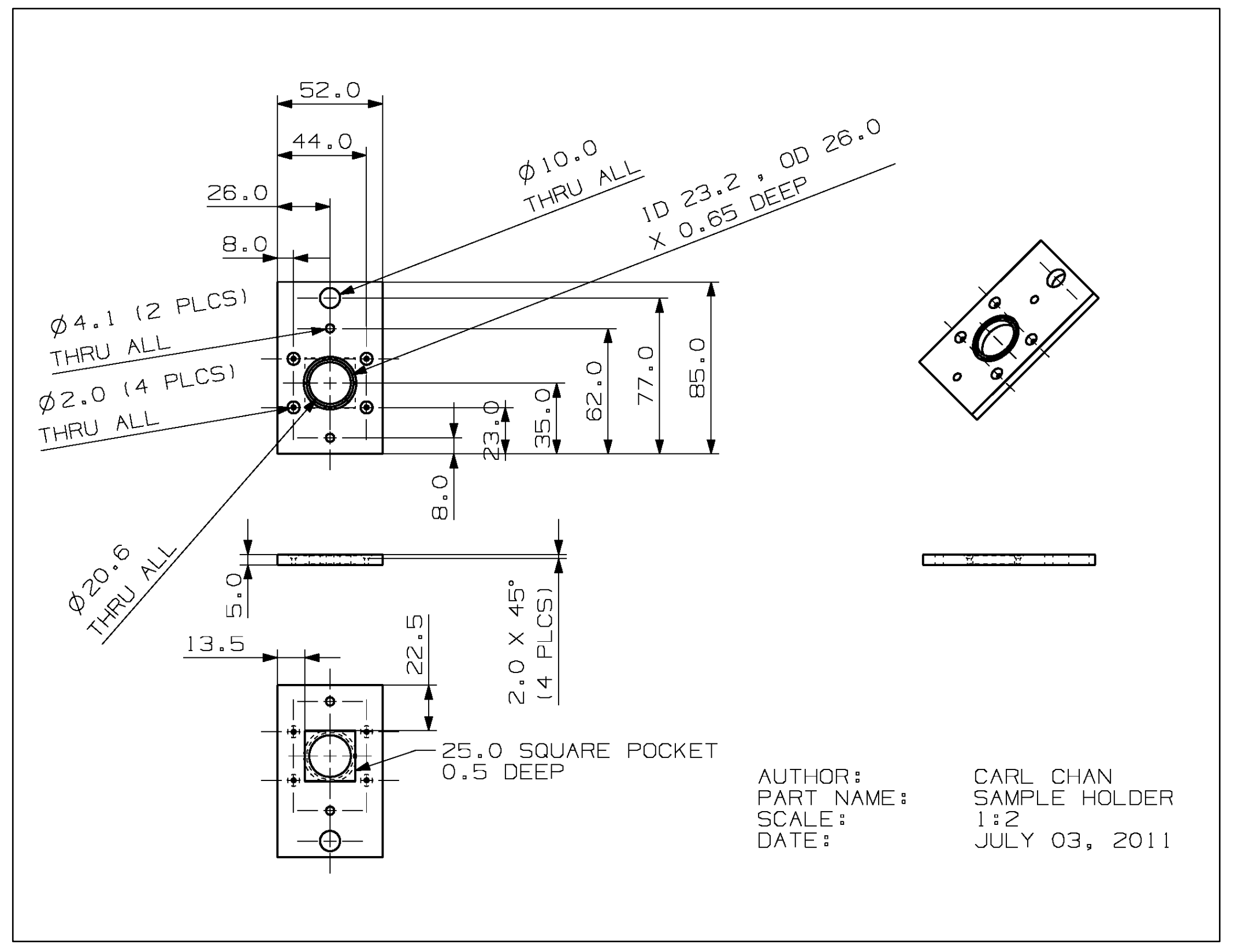




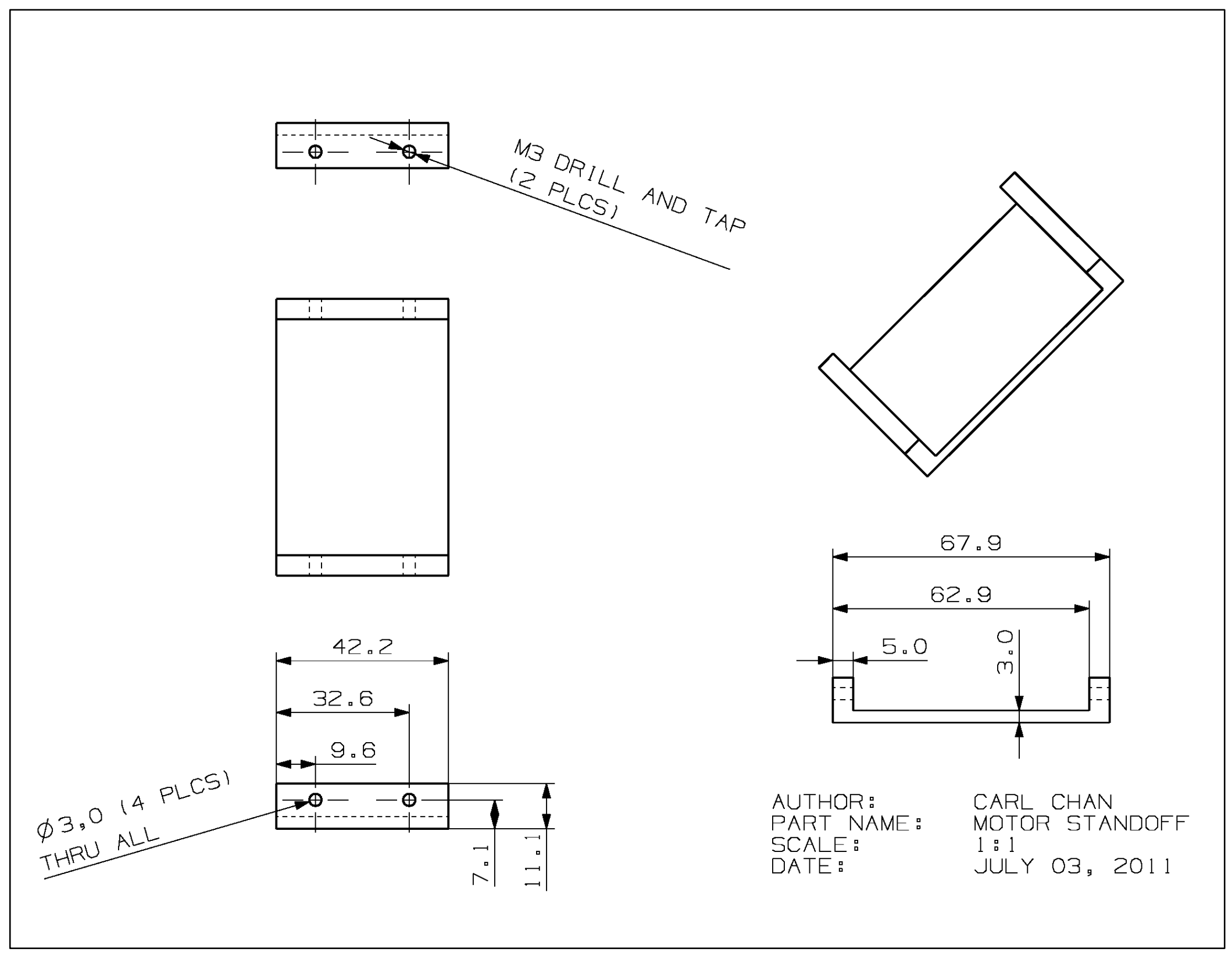




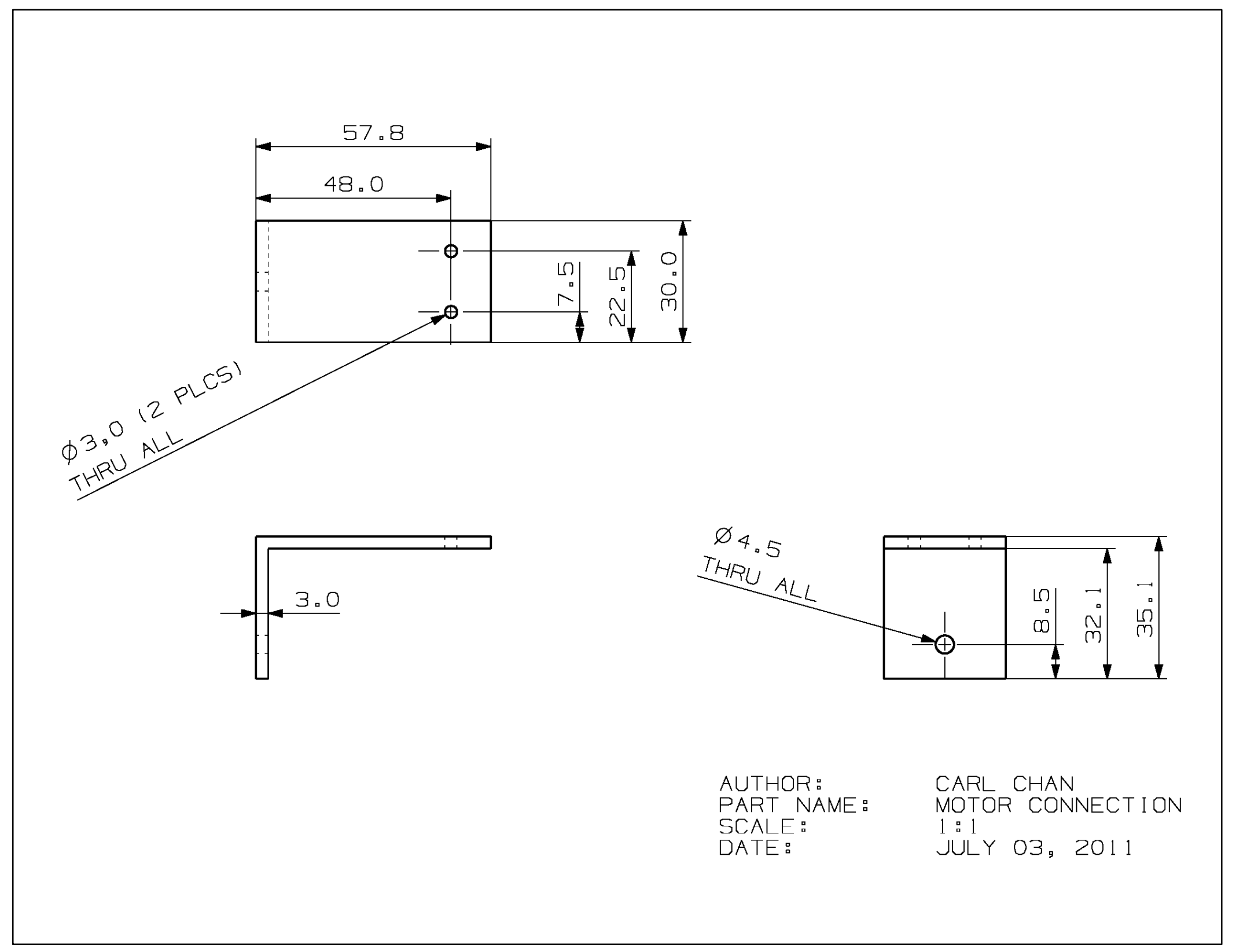




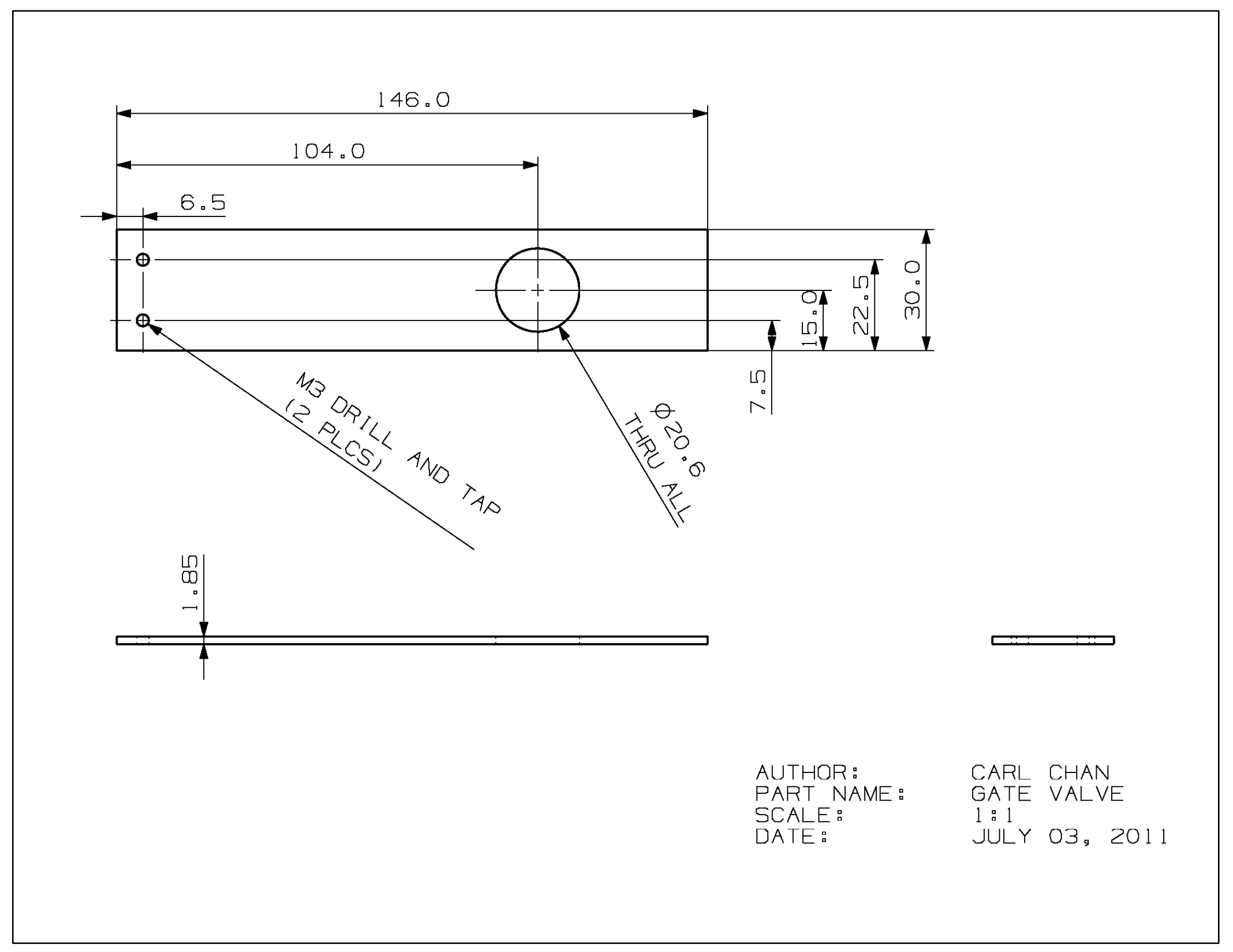




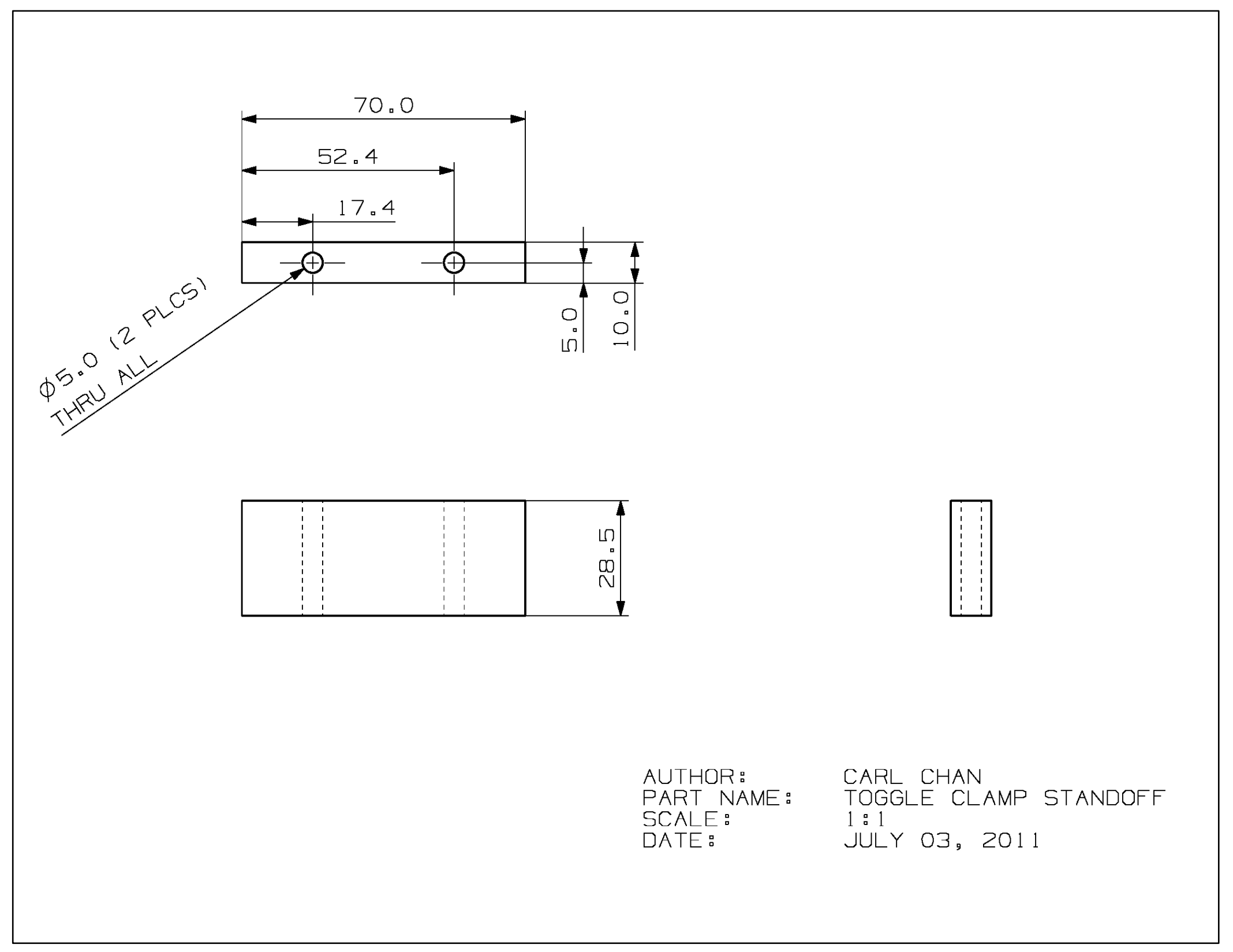




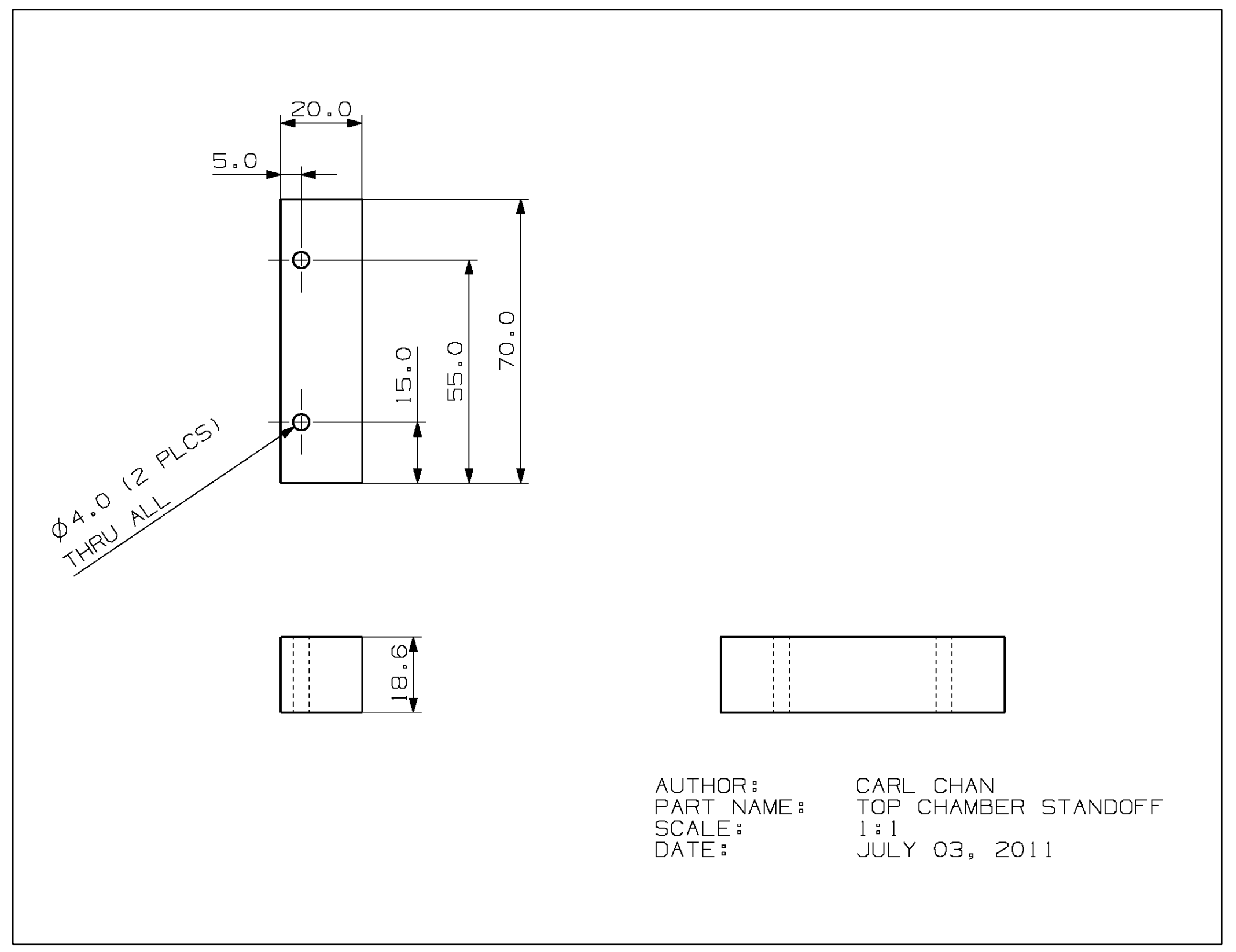




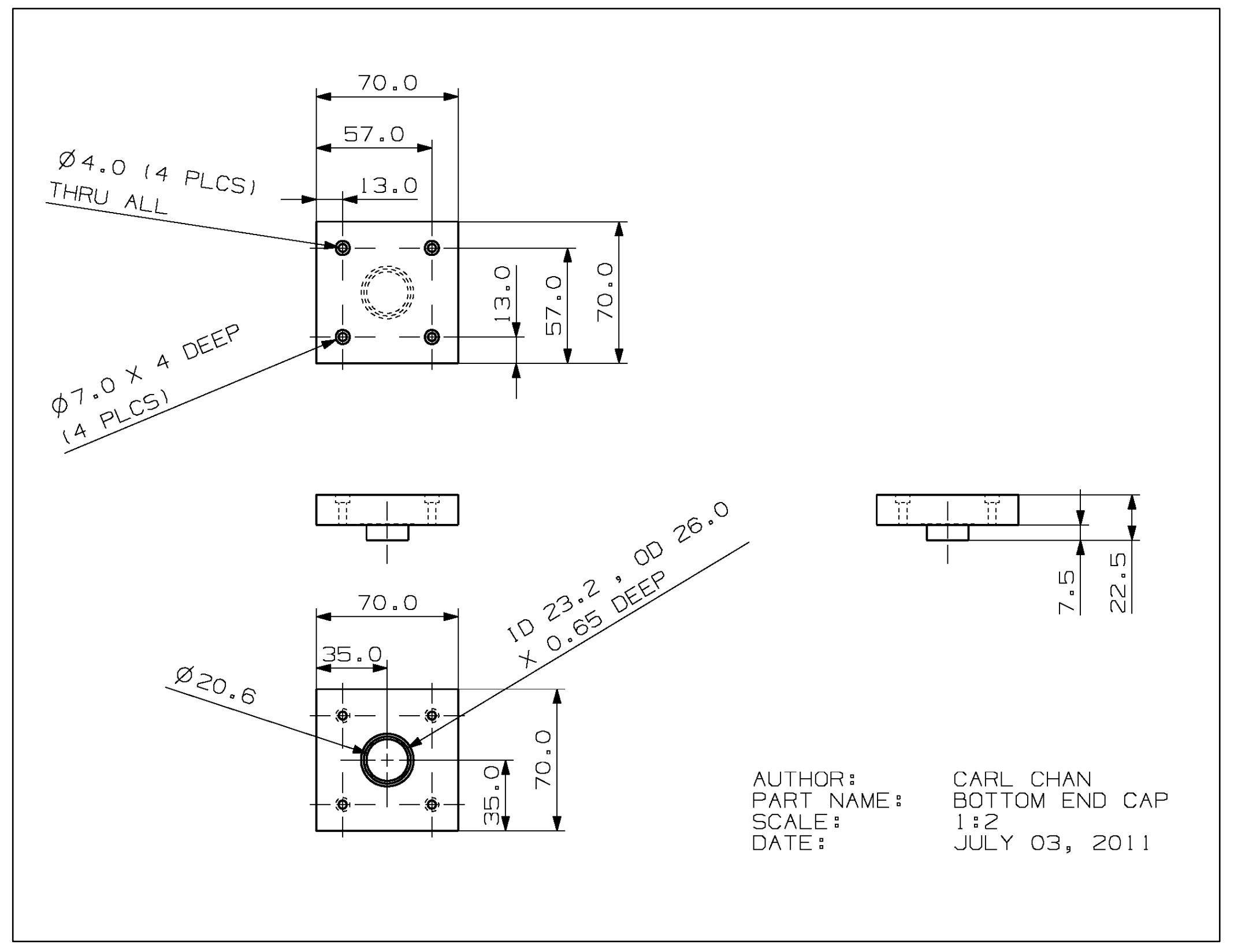




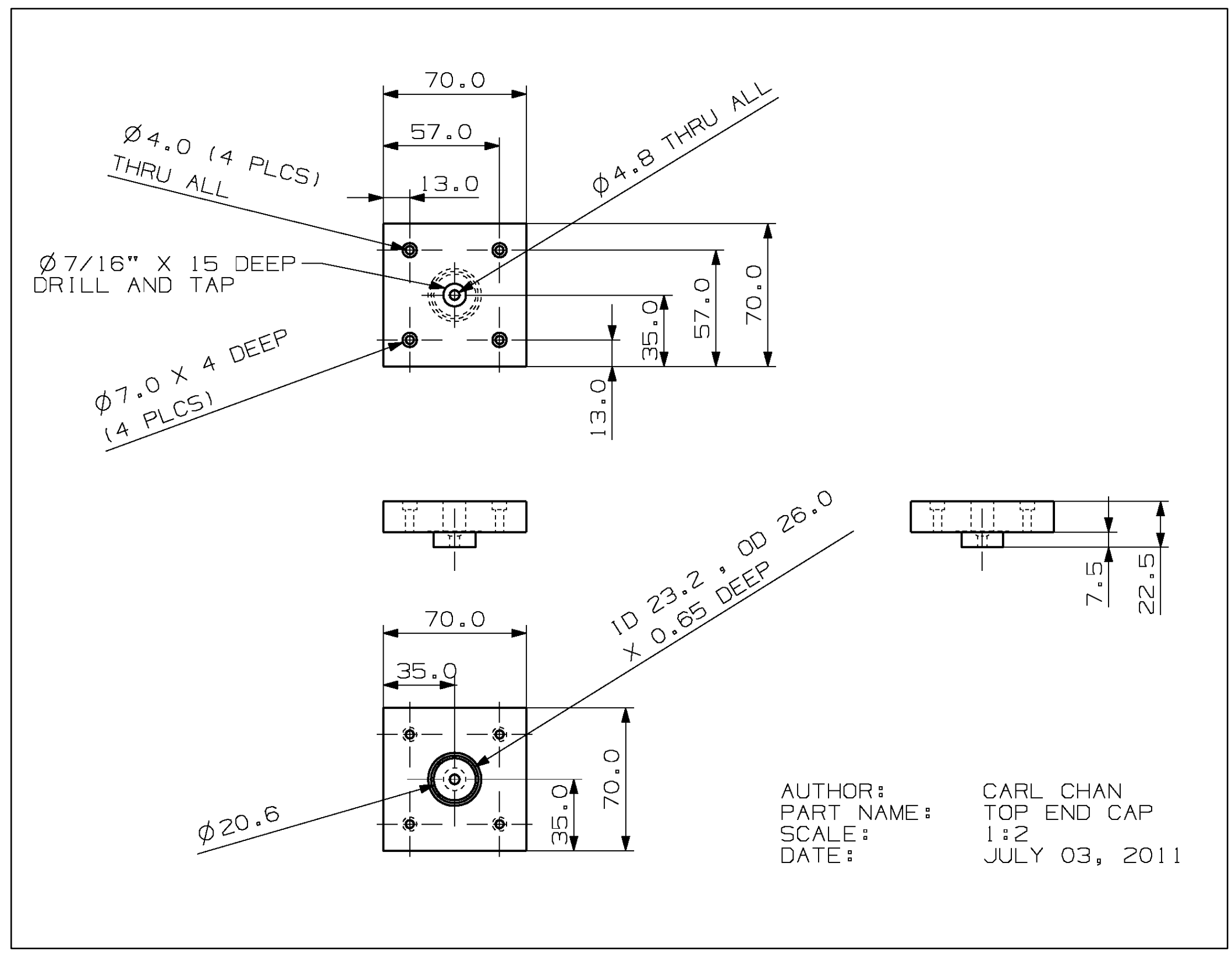




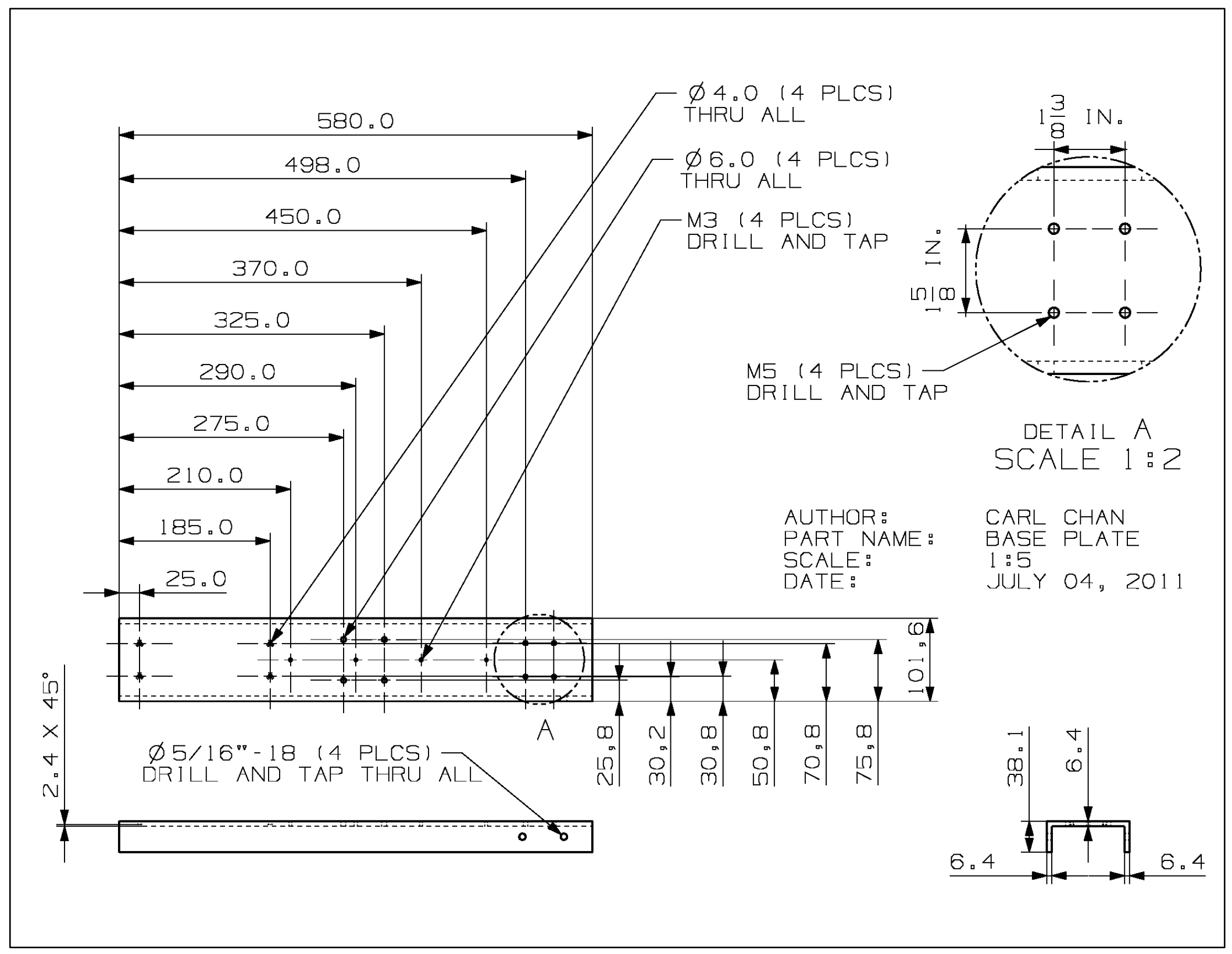




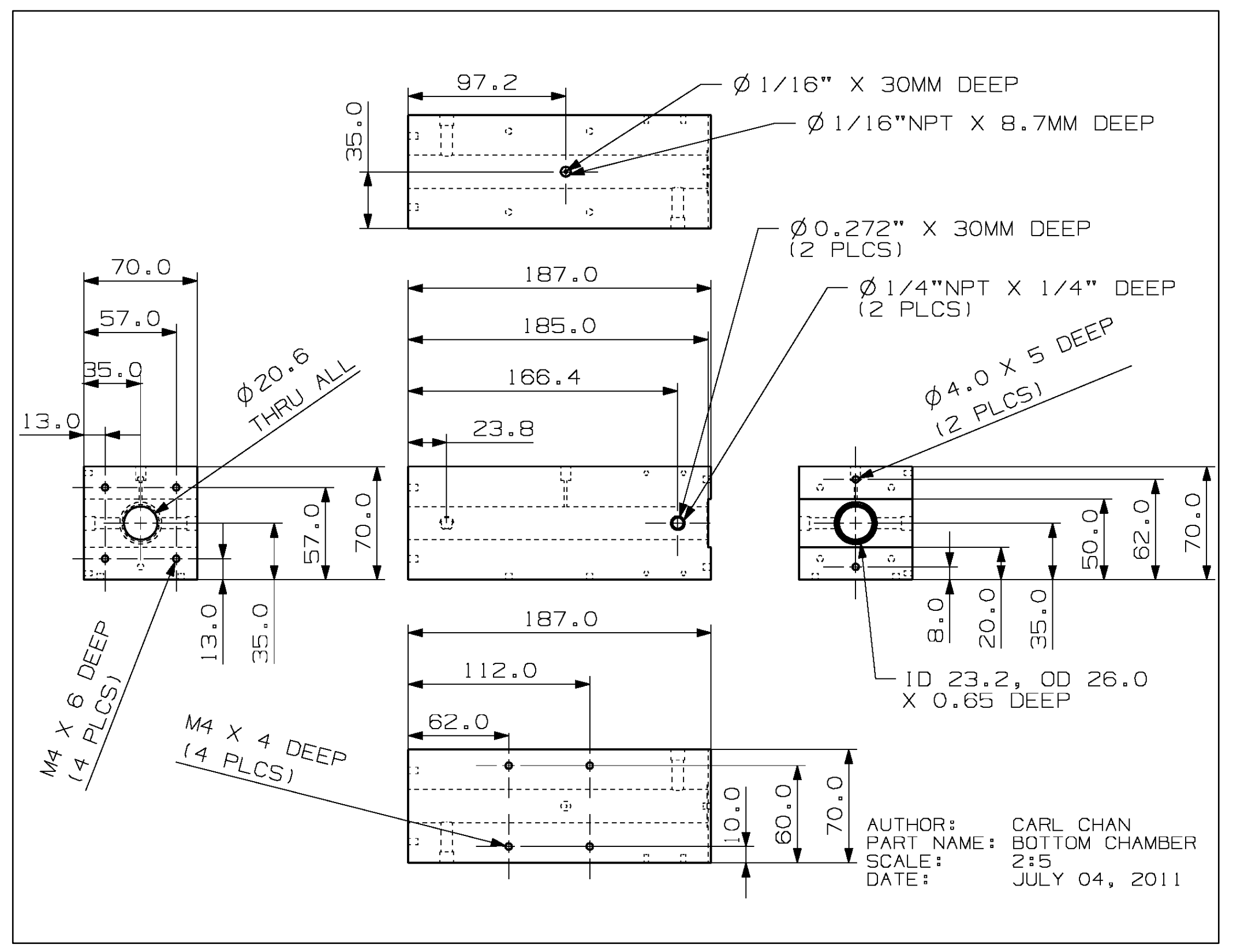




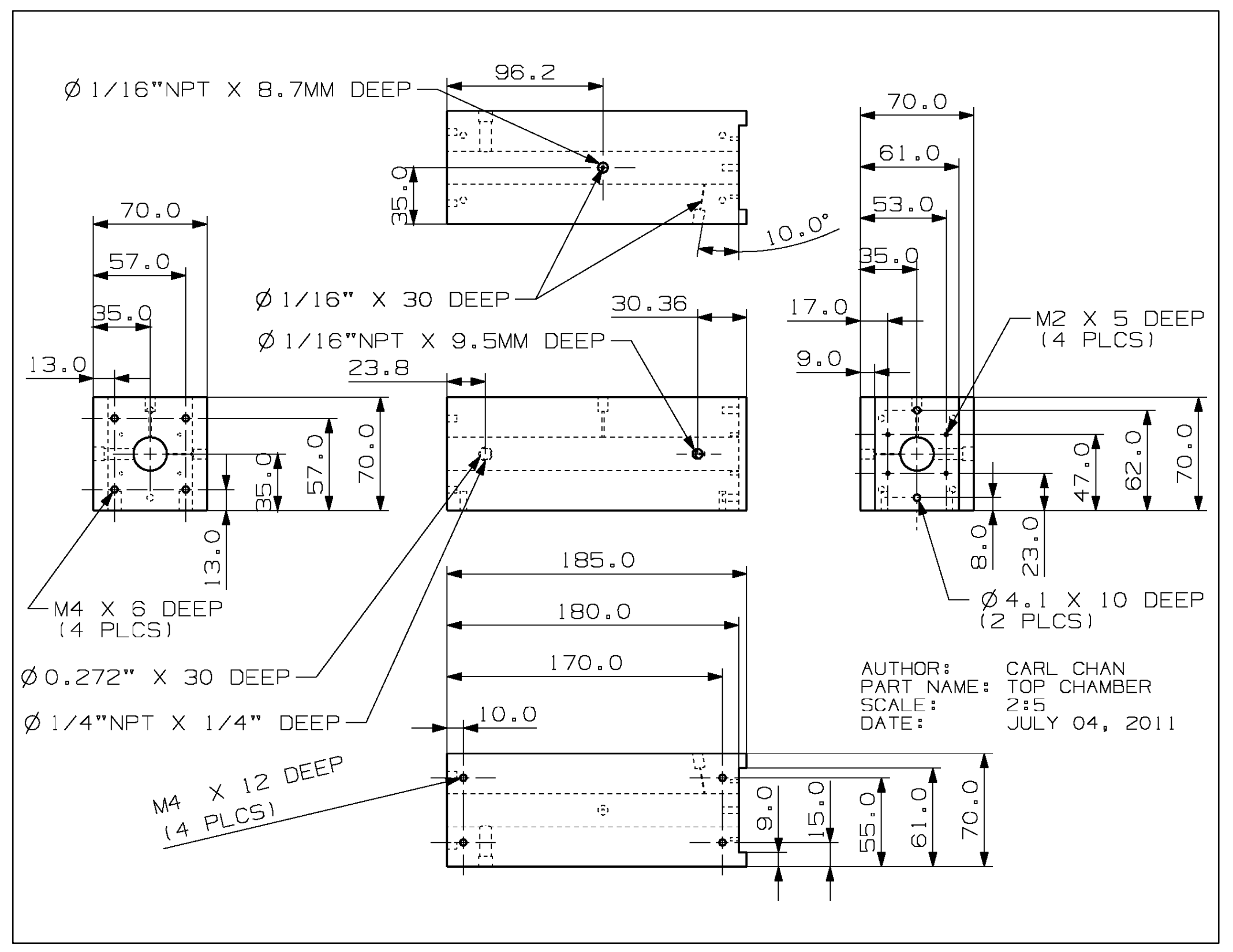




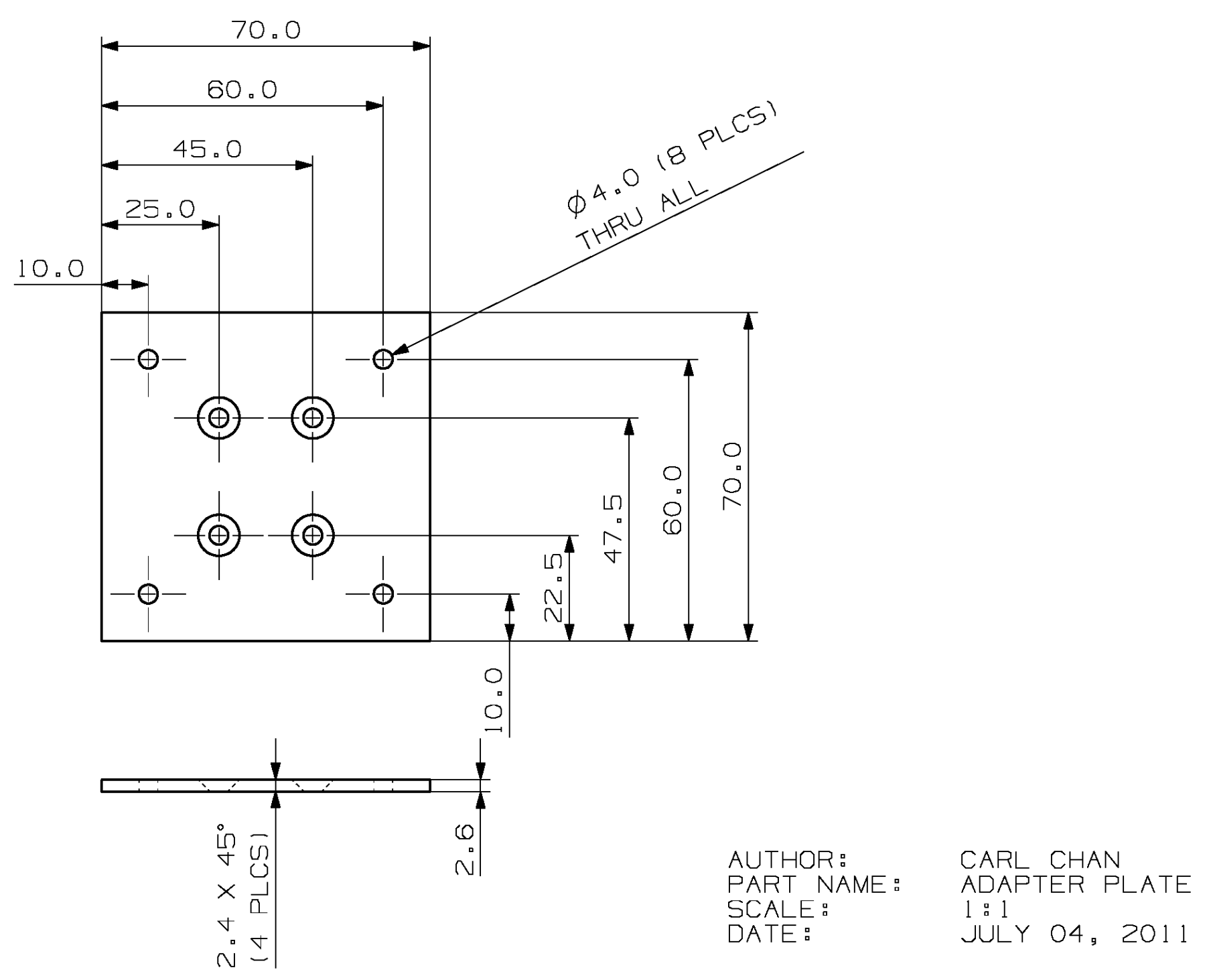



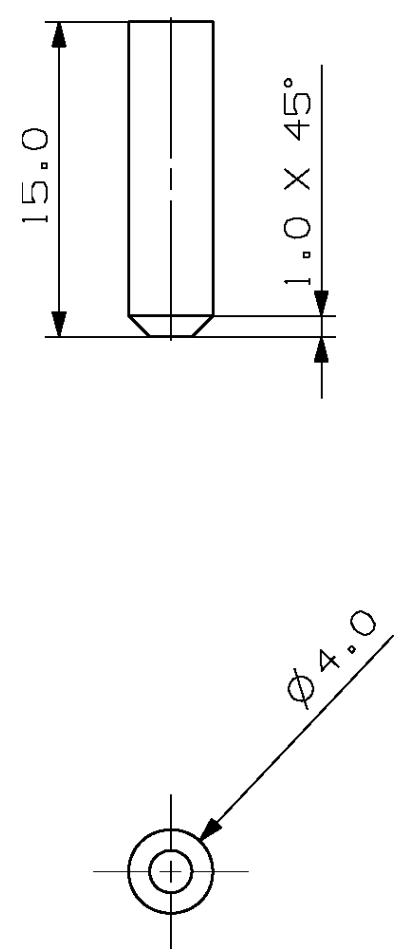

AUTHOR:

PART NAME:

SCALE:

CARL CHAN

OCATING PIN

$3: 1$

JUL Y 04, 2011 

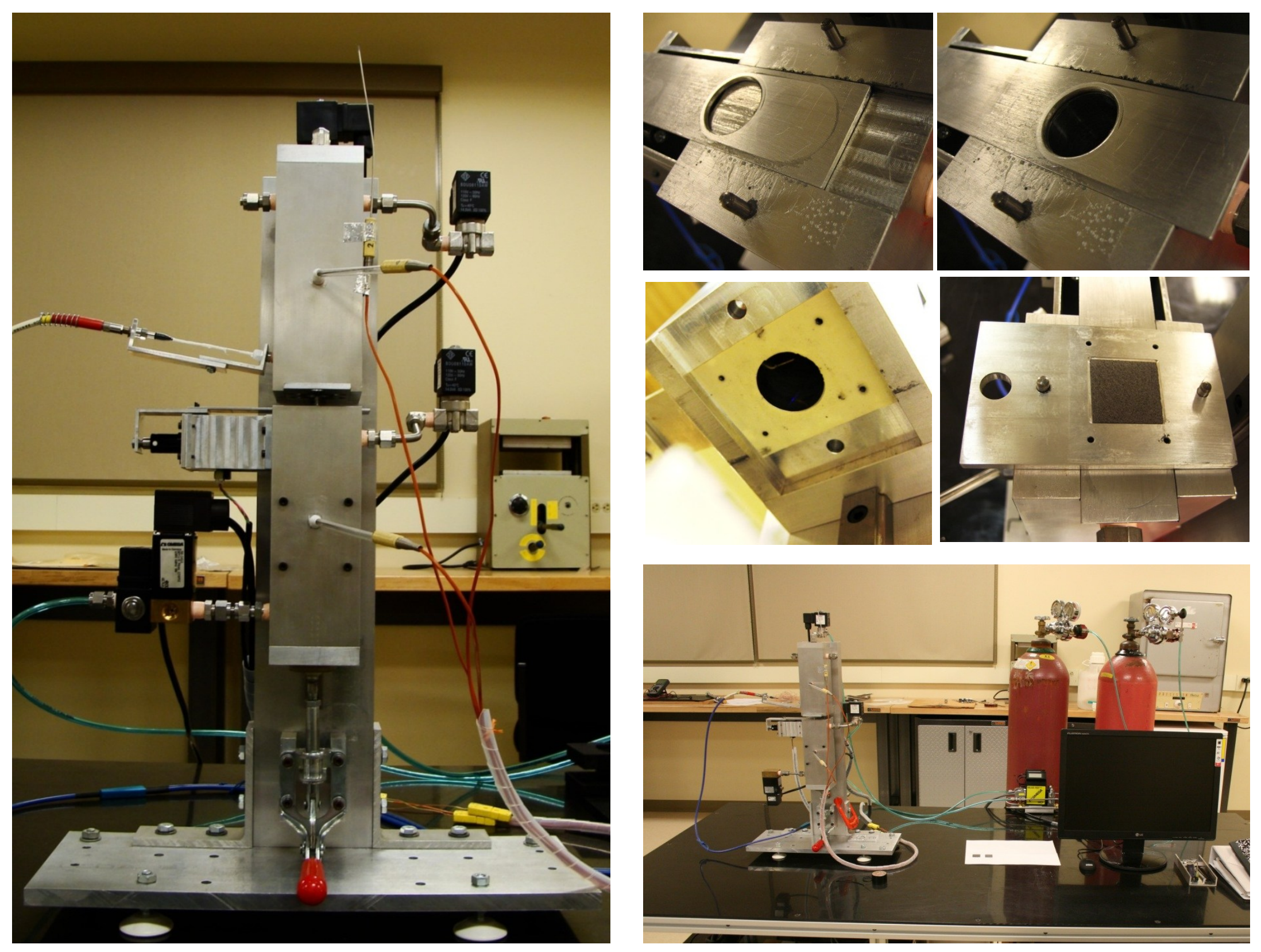
GAS FLOW SCHEMATIC FOR DIFFUSION CELL

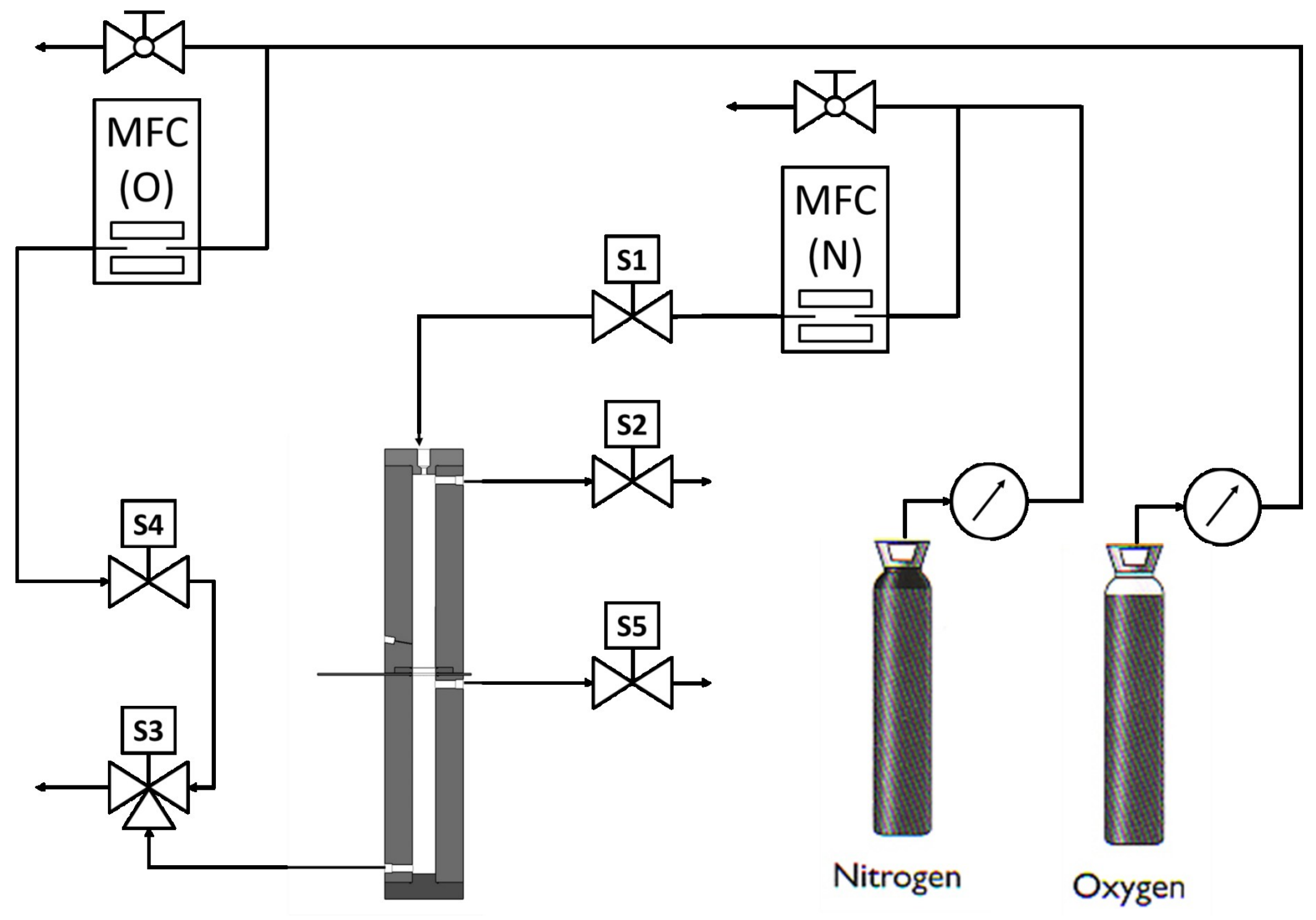




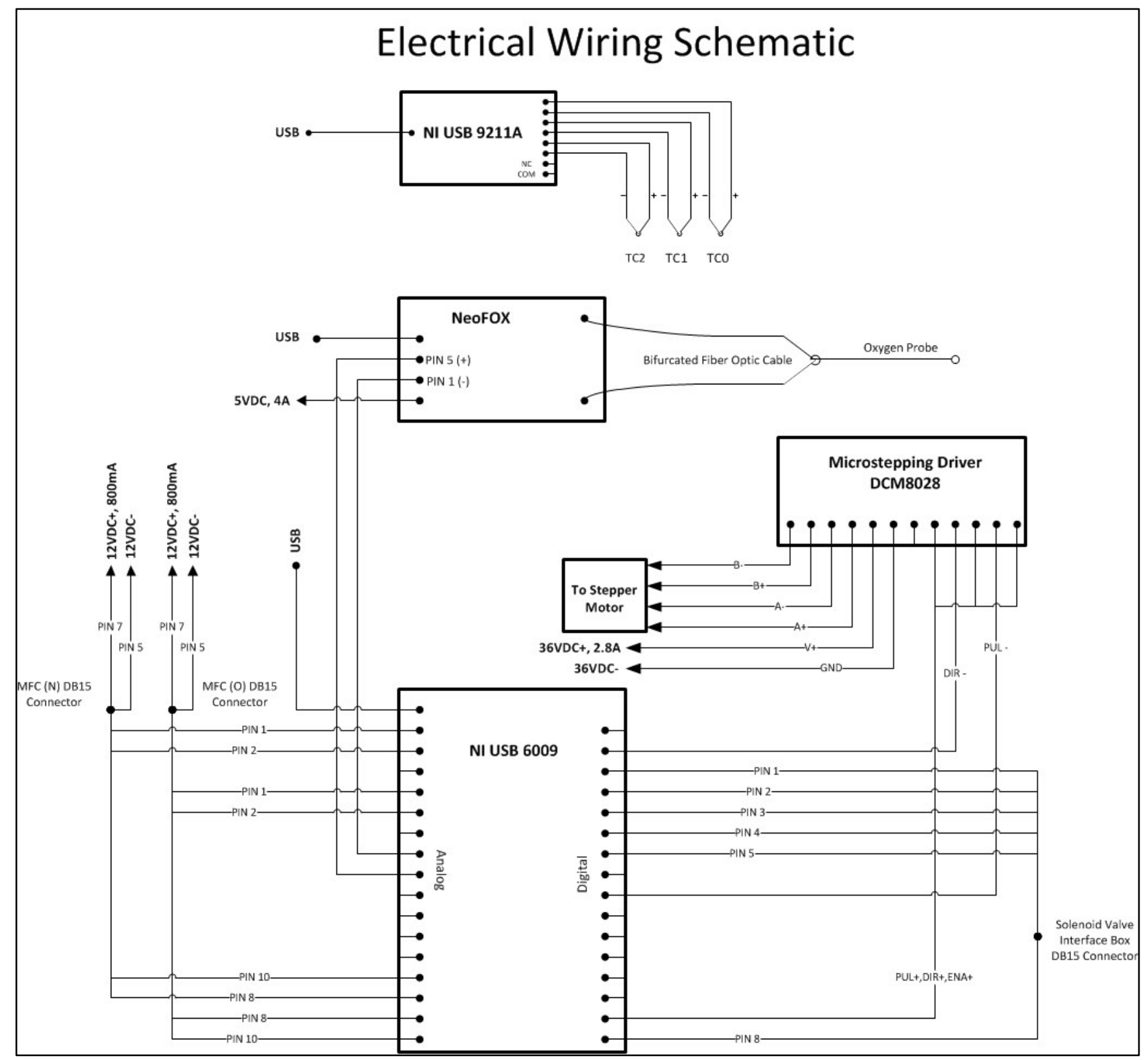


Solenoid Valve Interface Box - Nov 30/09
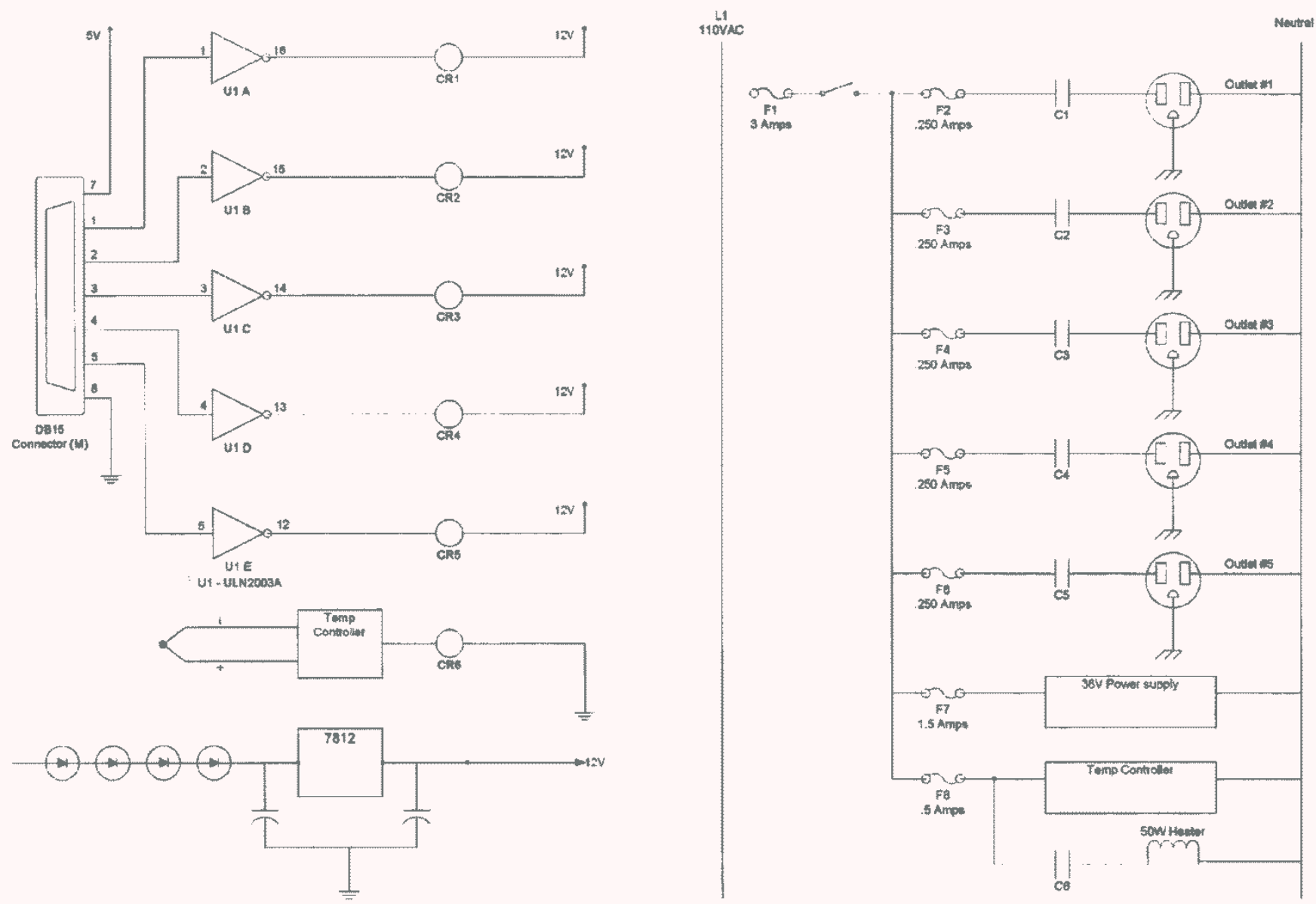


\section{Appendix B}

\section{Binary Diffusion Coefficients for Measured and Calculated Values}

\begin{tabular}{|c|c|c|c|c|c|c|c|}
\hline Trial & $\mathrm{D}_{\mathrm{eq}}$ & $\begin{array}{c}\text { Average } \\
\text { Temperature } \\
\left({ }^{\circ} \mathrm{C}\right)\end{array}$ & $\begin{array}{c}\text { Average } \\
\text { Pressure }(\mathrm{kPa})\end{array}$ & $\begin{array}{l}\text { Literature } \\
\text { Value }\end{array}$ & $\begin{array}{l}\text { 5.22\% Upper } \\
\text { Limit }\end{array}$ & $\begin{array}{l}\text { 5.22\% Lower } \\
\text { Limit }\end{array}$ & Bias Error \\
\hline Dec14_5 & $2.18 \mathrm{E}-05$ & 22.8 & 94.8 & 2.199E-05 & $2.314 \mathrm{E}-05$ & $2.090 \mathrm{E}-05$ & $0.81 \%$ \\
\hline Dec14_6 & $2.25 \mathrm{E}-05$ & 22.9 & 94.8 & $2.201 \mathrm{E}-05$ & $2.315 \mathrm{E}-05$ & $2.091 \mathrm{E}-05$ & $2.07 \%$ \\
\hline Dec14_7 & $2.18 \mathrm{E}-05$ & 22.9 & 94.8 & $2.200 \mathrm{E}-05$ & $2.315 \mathrm{E}-05$ & $2.091 \mathrm{E}-05$ & $0.96 \%$ \\
\hline Dec14_8 & 2.22E-05 & 22.9 & 94.8 & $2.200 \mathrm{E}-05$ & $2.315 \mathrm{E}-05$ & $2.091 \mathrm{E}-05$ & $1.05 \%$ \\
\hline Dec14_9 & $2.25 \mathrm{E}-05$ & 22.9 & 94.8 & $2.200 \mathrm{E}-05$ & $2.315 \mathrm{E}-05$ & $2.091 \mathrm{E}-05$ & $2.13 \%$ \\
\hline Dec15_4 & $2.20 \mathrm{E}-05$ & 22.5 & 95.2 & $2.187 \mathrm{E}-05$ & $2.301 \mathrm{E}-05$ & $2.078 \mathrm{E}-05$ & $0.59 \%$ \\
\hline Dec15_5 & $2.22 \mathrm{E}-05$ & 22.6 & 95.2 & $2.189 \mathrm{E}-05$ & $2.304 \mathrm{E}-05$ & $2.081 \mathrm{E}-05$ & $1.28 \%$ \\
\hline Dec15_6 & 2.24E-05 & 22.7 & 95.1 & $2.191 \mathrm{E}-05$ & $2.305 \mathrm{E}-05$ & $2.082 \mathrm{E}-05$ & $2.46 \%$ \\
\hline Dec17_6 & $2.18 \mathrm{E}-05$ & 22.5 & 95.4 & $2.182 \mathrm{E}-05$ & $2.295 \mathrm{E}-05$ & 2.073E-05 & $0.23 \%$ \\
\hline Dec17_7 & 2.17E-05 & 22.6 & 95.4 & 2.183E-05 & 2.297E-05 & 2.075E-05 & $0.70 \%$ \\
\hline Dec20_6 & 2.14E-05 & 22.5 & 96.0 & $2.169 \mathrm{E}-05$ & $2.283 \mathrm{E}-05$ & 2.062E-05 & $1.41 \%$ \\
\hline Dec21_5 & $2.20 \mathrm{E}-05$ & 22.5 & 96.3 & 2.163E-05 & $2.276 \mathrm{E}-05$ & $2.055 \mathrm{E}-05$ & $1.60 \%$ \\
\hline Dec22_4 & 2.14E-05 & 22.4 & 95.8 & 2.172E-05 & $2.285 \mathrm{E}-05$ & 2.064E-05 & $1.68 \%$ \\
\hline Jan10_4 & $2.16 \mathrm{E}-05$ & 23.6 & 96.8 & 2.165E-05 & 2.278E-05 & $2.058 \mathrm{E}-05$ & $0.32 \%$ \\
\hline Jan11_4 & 2.23E-05 & 24.0 & 96.2 & 2.184E-05 & $2.298 \mathrm{E}-05$ & $2.075 \mathrm{E}-05$ & $2.18 \%$ \\
\hline Jan12_4 & $2.20 \mathrm{E}-05$ & 24.2 & 95.8 & 2.195E-05 & 2.309E-05 & $2.086 \mathrm{E}-05$ & $0.44 \%$ \\
\hline Jan16_4 & $2.22 \mathrm{E}-05$ & 24.0 & 96.3 & $2.180 \mathrm{E}-05$ & 2.294E-05 & $2.072 \mathrm{E}-05$ & $2.01 \%$ \\
\hline Jan20_3 & $2.22 \mathrm{E}-05$ & 23.9 & 95.8 & $2.192 \mathrm{E}-05$ & $2.306 \mathrm{E}-05$ & 2.083E-05 & $1.45 \%$ \\
\hline Jan22_3 & 2.19E-05 & 23.7 & 95.4 & 2.197E-05 & $2.311 \mathrm{E}-05$ & $2.088 \mathrm{E}-05$ & $0.30 \%$ \\
\hline Jan25_4 & 2.15E-05 & 22.6 & 95.8 & $2.174 \mathrm{E}-05$ & $2.288 \mathrm{E}-05$ & 2.066E-05 & $1.23 \%$ \\
\hline Jan25_5 & 2.19E-05 & 22.7 & 95.8 & 2.175E-05 & $2.288 \mathrm{E}-05$ & 2.067E-05 & $0.78 \%$ \\
\hline Jan26_5 & 2.13E-05 & 22.7 & 95.6 & 2.179E-05 & $2.293 \mathrm{E}-05$ & $2.071 \mathrm{E}-05$ & $2.09 \%$ \\
\hline Jan27_3 & 2.15E-05 & 22.9 & 95.3 & 2.190E-05 & $2.304 \mathrm{E}-05$ & $2.081 \mathrm{E}-05$ & $1.74 \%$ \\
\hline Jan28_3 & $2.13 \mathrm{E}-05$ & 22.9 & 95.0 & 2.196E-05 & $2.310 \mathrm{E}-05$ & 2.087E-05 & $2.85 \%$ \\
\hline Feb01_6 & $2.08 \mathrm{E}-05$ & 22.2 & 96.6 & $2.151 \mathrm{E}-05$ & $2.264 \mathrm{E}-05$ & $2.045 \mathrm{E}-05$ & $3.22 \%$ \\
\hline Feb02_4 & $2.13 \mathrm{E}-05$ & 22.3 & 94.6 & 2.197E-05 & $2.312 \mathrm{E}-05$ & $2.088 \mathrm{E}-05$ & $2.95 \%$ \\
\hline Mar20_4 & 2.14E-05 & 22.1 & 97.5 & $2.131 \mathrm{E}-05$ & $2.242 \mathrm{E}-05$ & 2.025E-05 & $0.49 \%$ \\
\hline Mar28_9 & $2.13 \mathrm{E}-05$ & 22.7 & 96.3 & 2.164E-05 & $2.276 \mathrm{E}-05$ & 2.056E-05 & $1.39 \%$ \\
\hline Mar29_5 & 2.14E-05 & 22.3 & 96.5 & 2.154E-05 & 2.267E-05 & 2.047E-05 & $0.66 \%$ \\
\hline May02_3 & $2.23 \mathrm{E}-05$ & 25.7 & 96.0 & 2.209E-05 & 2.324E-05 & 2.100E-05 & $0.88 \%$ \\
\hline
\end{tabular}




\section{Appendix C}

\section{LabView Code for Diffusion Apparatus}

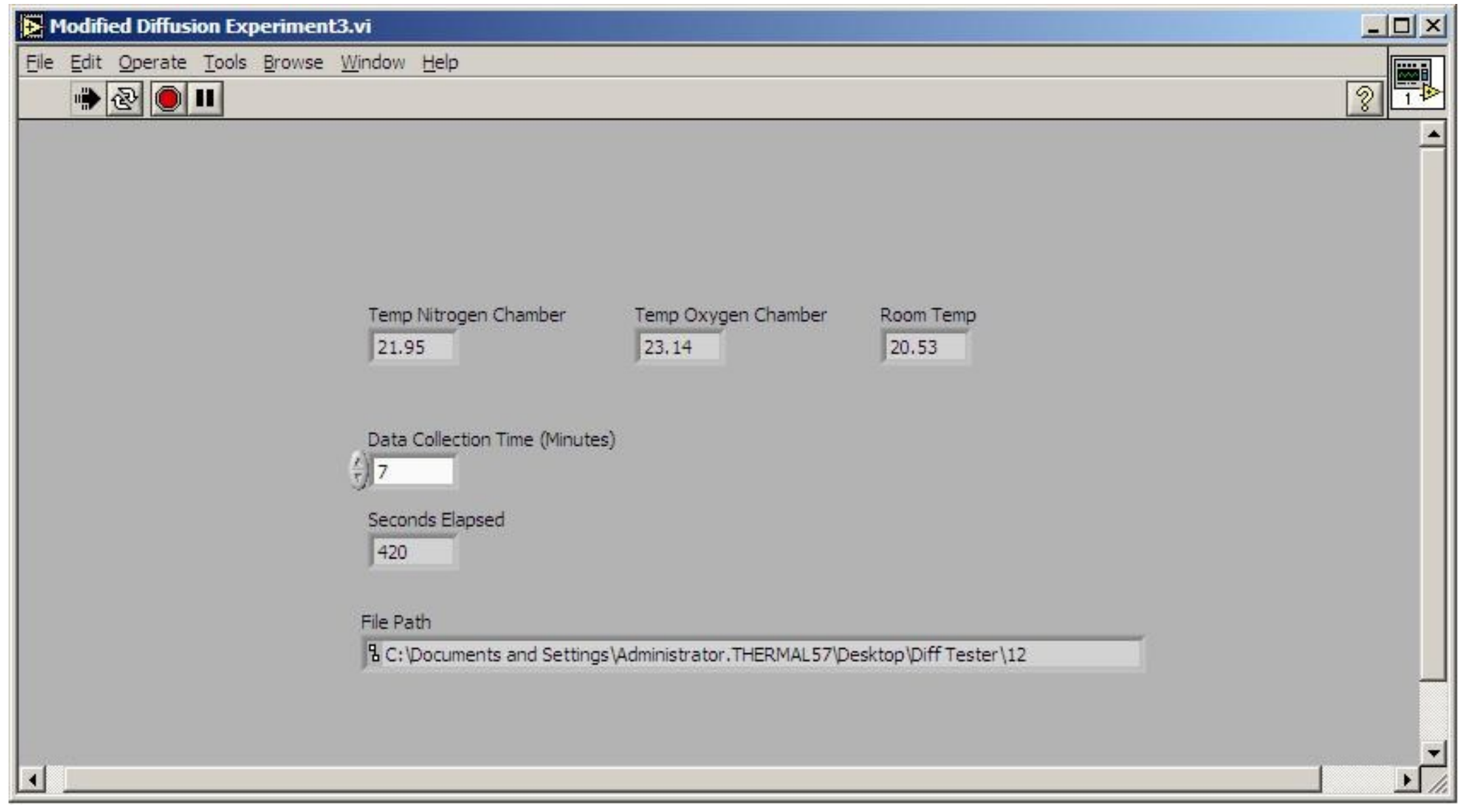




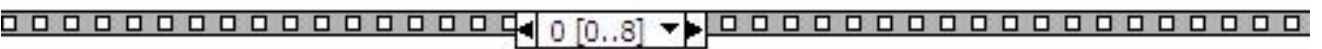

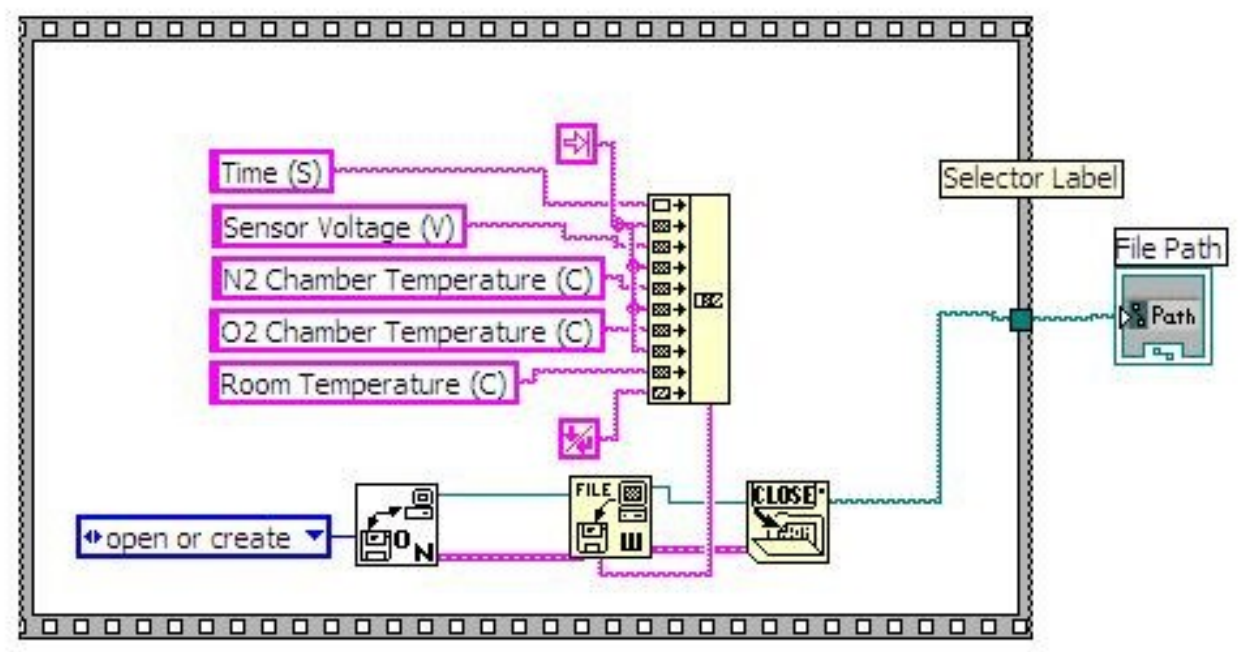

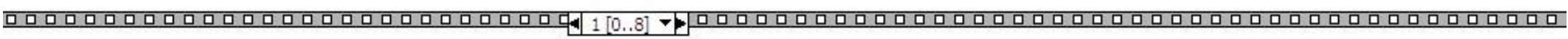
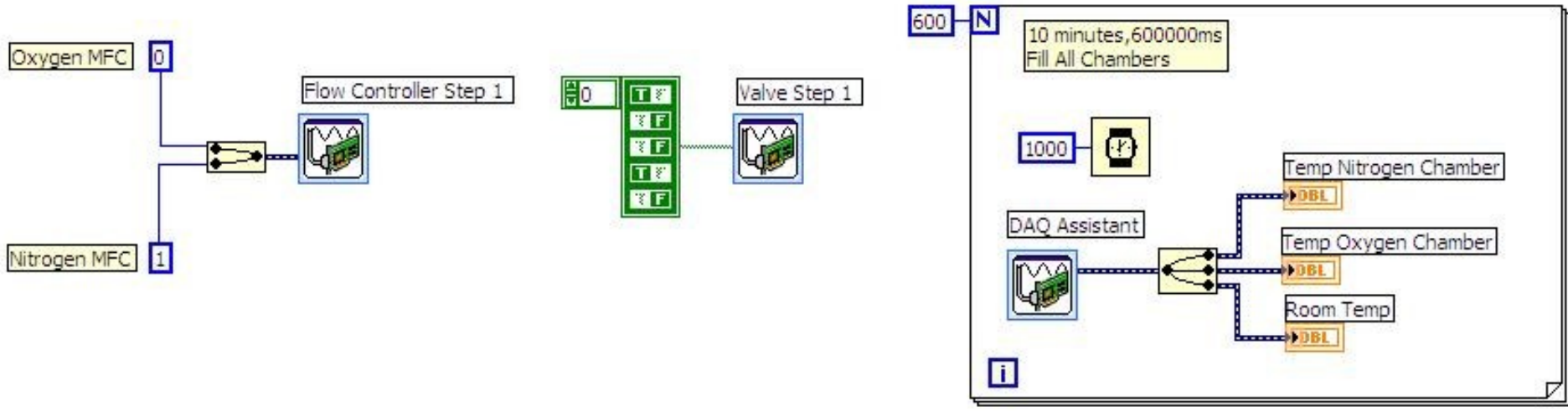


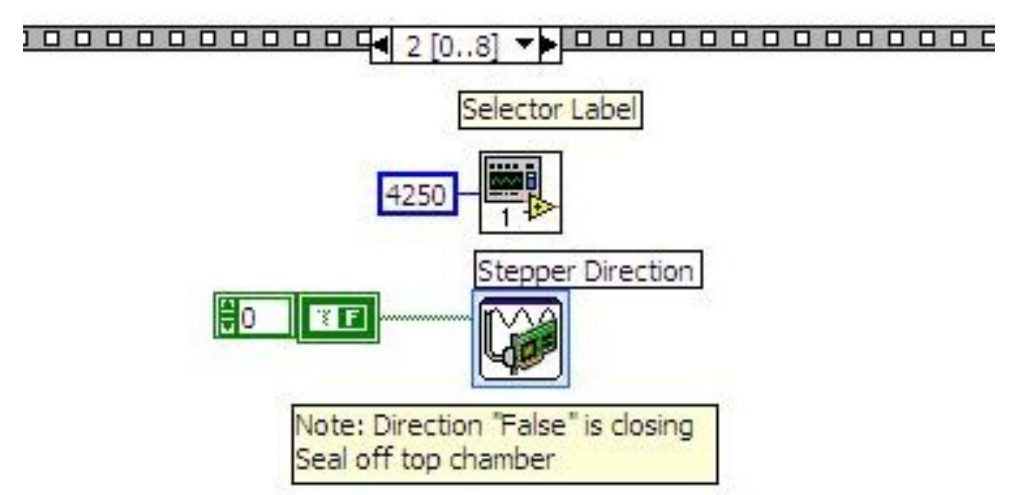

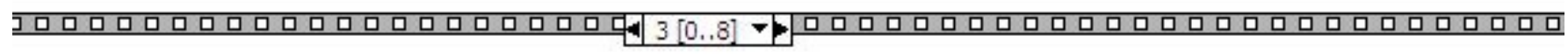

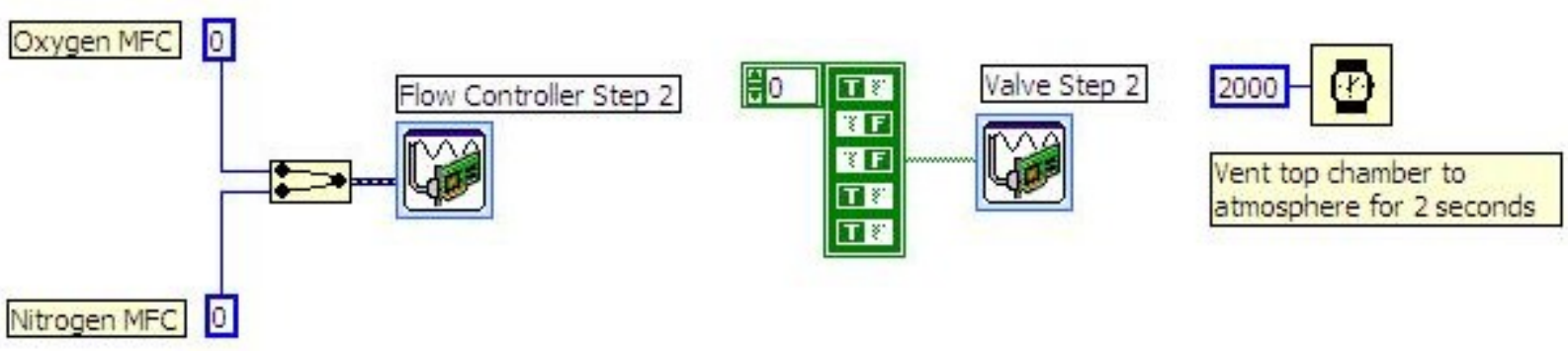

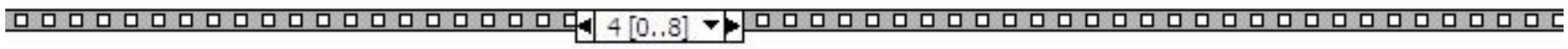

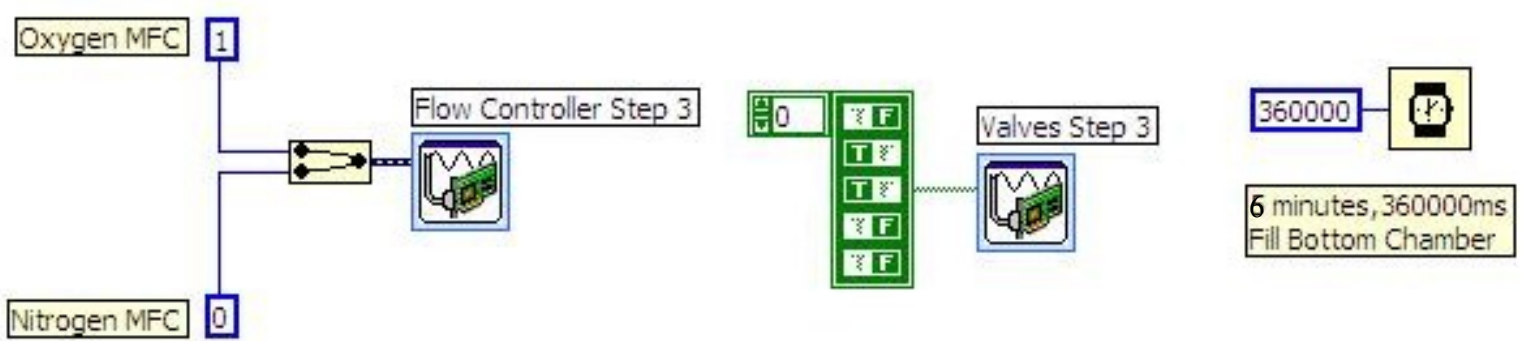




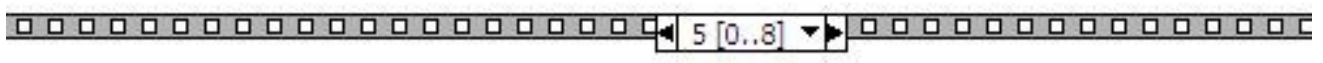

Oxygen MFC

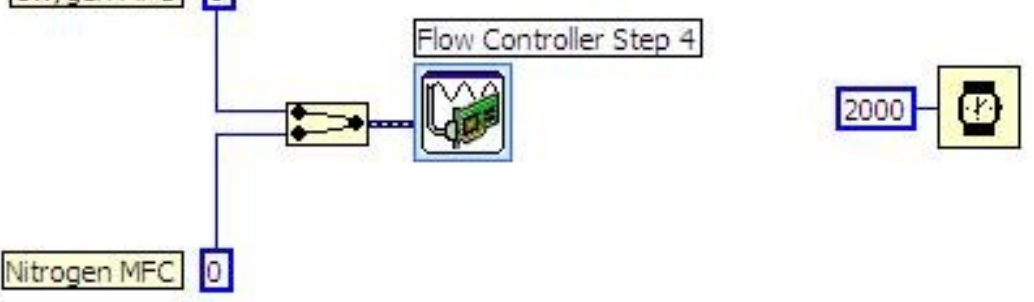

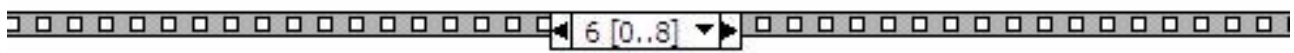

\begin{tabular}{|c|c|c|c|}
\hline & 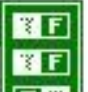 & Valves Step 4 & $4000-7$. \\
\hline & F防 & no & $\begin{array}{l}\text { Vent bottom chamber to } \\
\text { atmosphere for } 4 \text { seconds }\end{array}$ \\
\hline
\end{tabular}

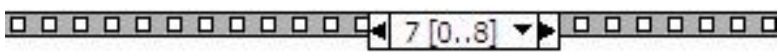

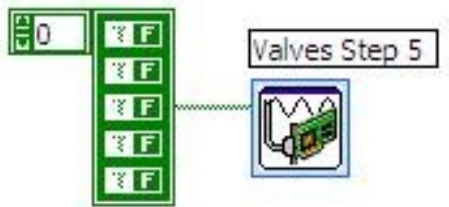




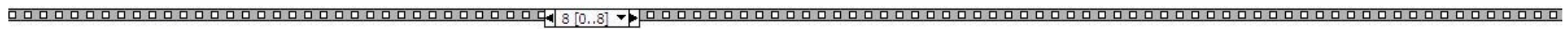
bata Collection Time (Minutes)

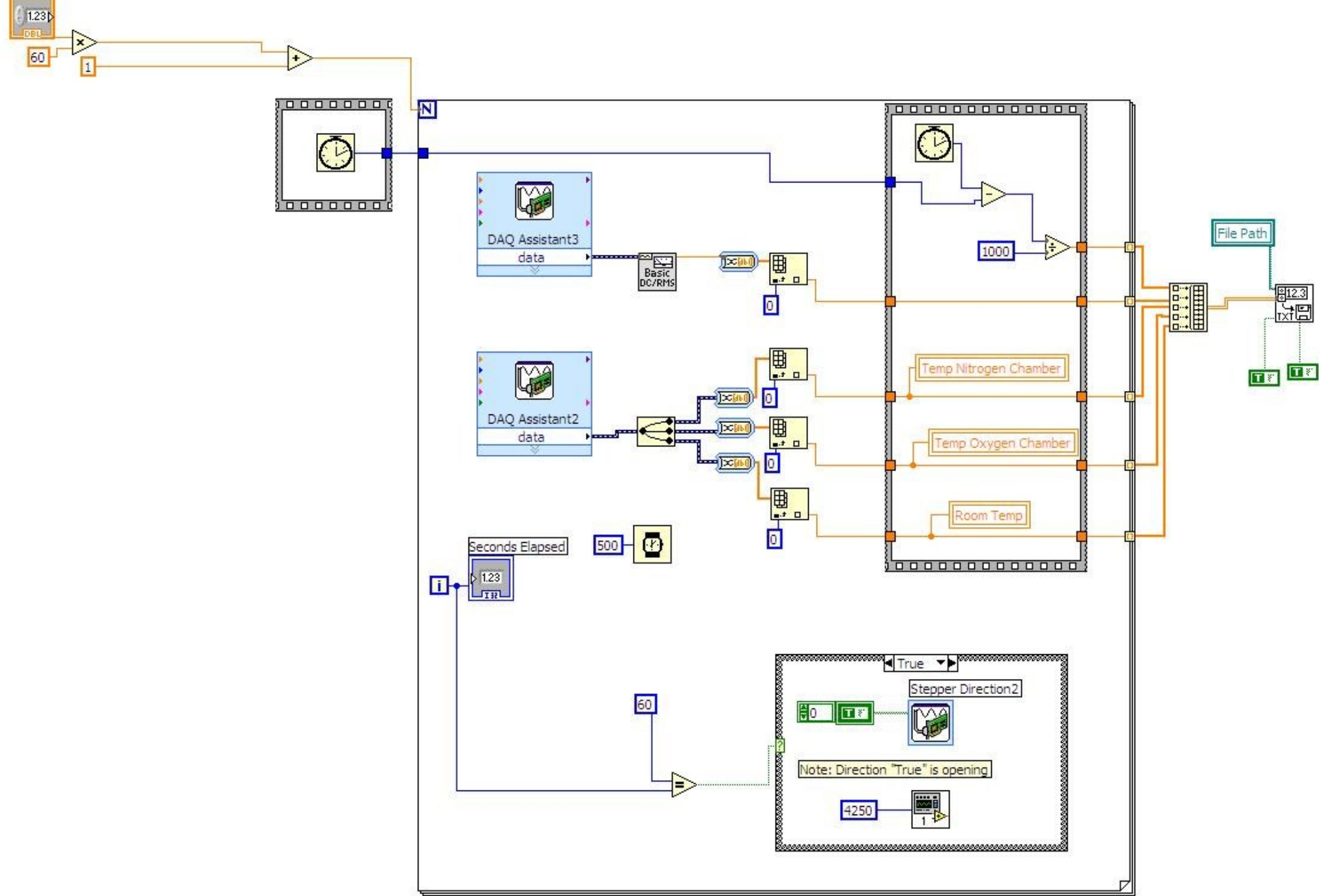




\section{Appendix D}

\section{Porosity Measurements for GDL Samples}

\begin{tabular}{|c|c|c|c|c|c|c|c|c|c|c|c|c|c|}
\hline Name of the Sample & Toray TGP & $\mathrm{H}-120, \mathrm{~F}$ & & & & & & & & & & & \\
\hline Trial \# & \begin{tabular}{|l|}
1 \\
\end{tabular} & 2 & 3 & 4 & 5 & 6 & 7 & 8 & 9 & 10 & & & \\
\hline Working liquid & Octane & & & & & & & & & & & & \\
\hline Density of the liquid, $\mathrm{cm} 3 / \mathrm{g}(25 \mathrm{C})$ & 0.7022 & 0.7022 & 0.7022 & 0.7022 & 0.7022 & 0.7022 & 0.7022 & 0.7022 & 0.7022 & 0.7022 & & & \\
\hline Surface tension, dine/cm (25C) & 21.75 & 21.75 & 21.75 & 21.75 & 21.75 & 21.75 & 21.75 & 21.75 & 21.75 & 21.75 & & & \\
\hline Mole volume, $\mathrm{cm} 3 / \mathrm{mol}(25 \mathrm{C})$ & 162.6 & 162.6 & 162.6 & 162.6 & 162.6 & 162.6 & 162.6 & 162.6 & 162.6 & 162.6 & & & \\
\hline Mass of the bottle for sample, $\mathrm{g}$ & 0 & 0 & 0 & 0 & 0 & 0 & 0 & 0 & 0 & 0 & & & \\
\hline Dry mass bottle+sample, $\mathrm{g}$ & 0.0749 & 0.0749 & 0.0749 & 0.0749 & 0.0749 & 0.0749 & 0.0749 & 0.0749 & 0.0749 & 0.0749 & & & \\
\hline Mass sample in the liquid, $g$ & 0.0474 & 0.0454 & 0.0473 & 0.0475 & 0.0474 & 0.0478 & 0.0476 & 0.0474 & 0.0474 & 0.0467 & & & \\
\hline Wet mass bottle+sample, $g$ & 0.151 & 0.1433 & 0.1388 & 0.1434 & 0.1415 & 0.1446 & 0.1408 & 0.1407 & 0.1417 & 0.1405 & & & \\
\hline Dry mass of the sample, $g$ & 0.0749 & 0.0749 & 0.0749 & 0.0749 & 0.0749 & 0.0749 & 0.0749 & 0.0749 & 0.0749 & 0.0749 & & & \\
\hline Volume of solid components, $\mathrm{cm} 3$ & 0.0392 & 0.0420 & 0.0393 & 0.0390 & 0.0392 & 0.0386 & 0.0389 & 0.0392 & 0.0392 & 0.0402 & & & \\
\hline Wet mass of the sample, $g$ & 0.151 & 0.1433 & 0.1388 & 0.1434 & 0.1415 & 0.1446 & 0.1408 & 0.1407 & 0.1417 & 0.1405 & & & \\
\hline Volume of the sample (calculated), cm3 & 0.1475 & 0.1394 & 0.1303 & 0.1366 & 0.1340 & 0.1379 & 0.1327 & 0.1329 & 0.1343 & 0.1336 & & & \\
\hline Pore volume or volume of the liquid, cm 3 & 0.1084 & 0.0974 & 0.0910 & 0.0976 & 0.0948 & 0.0993 & 0.0938 & 0.0937 & 0.0951 & 0.0934 & avg & stdev & limit \\
\hline Porosity over volume, $\mathrm{cm} 3 / \mathrm{cm} 3$ & 0.7346 & 0.6987 & 0.6984 & 0.7143 & 0.7078 & 0.7200 & 0.7071 & 0.7053 & 0.7084 & 0.6994 & 0.7094 & 0.0112 & 0.008029 \\
\hline Porosity over weight, $\mathrm{cm} 3 / \mathrm{g}$ & 1.4469 & 1.3005 & 1.2149 & 1.3024 & 1.2663 & 1.3252 & 1.2530 & 1.2511 & 1.2701 & 1.2473 & & & \\
\hline Density of solid $\mathrm{g} / \mathrm{cm} 3$ & 1.9125 & 1.7829 & 1.9056 & 1.9195 & 1.9125 & 1.9408 & 1.9265 & 1.9125 & 1.9125 & 1.8651 & & & \\
\hline Density of the sample, $\mathrm{g} / \mathrm{cm} 3$ & 0.5077 & 0.5372 & 0.5748 & 0.5484 & 0.5589 & 0.5433 & 0.5643 & 0.5637 & 0.5577 & 0.5607 & & & \\
\hline
\end{tabular}




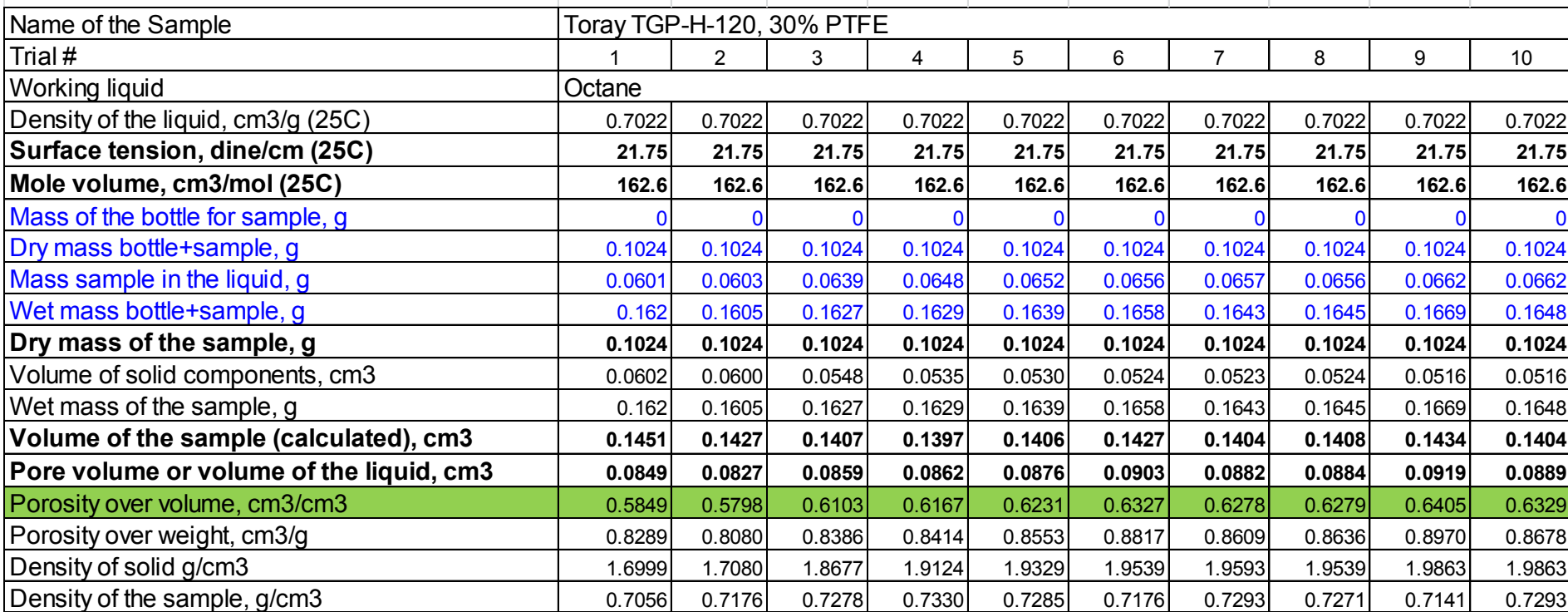

\begin{tabular}{|c|c|c|c|c|c|c|c|c|c|c|}
\hline Name of the Sample & Toray TGP & $\mathrm{H}-120$, & $\%$ PTF & & & & & & & \\
\hline Trial \# & \begin{tabular}{|l|l}
1 & \\
\end{tabular} & \begin{tabular}{l|l}
2 & \\
\end{tabular} & \begin{tabular}{l|l}
3 & \\
\end{tabular} & 4 & 5 & 6 & 7 & 8 & 9 & 10 \\
\hline Density of the liquid, $\mathrm{cm} 3 / \mathrm{g}(25 \mathrm{C})$ & 0.7022 & 0.7022 & 0.7022 & 0.7022 & 0.7022 & 0.7022 & 0.7022 & 0.7022 & 0.7022 & 0.7022 \\
\hline Mole volume, $\mathrm{cm} 3 / \mathrm{mol}(25 \mathrm{C})$ & 162.6 & 162.6 & 162.6 & 162.6 & 162.6 & 162.6 & 162.6 & 162.6 & 162.6 & 162.6 \\
\hline Mass of the bottle for sample, $\mathrm{g}$ & 0 & 0 & 0 & 0 & 0 & 0 & 0 & 0 & 0 & 0 \\
\hline Dry mass bottle+sample, $g$ & 0.1748 & 0.1748 & 0.1748 & 0.1748 & 0.1748 & 0.1748 & 0.1748 & 0.1748 & 0.1748 & 0.1748 \\
\hline Dry mass of the sample, $g$ & 0.1748 & 0.1748 & 0.1748 & 0.1748 & 0.1748 & 0.1748 & 0.1748 & 0.1748 & 0.1748 & 0.1748 \\
\hline Volume of solid components, $\mathrm{cm} 3$ & 0.1034 & 0.1015 & 0.0971 & 0.0948 & 0.0924 & 0.0906 & 0.0900 & 0.0890 & 0.0877 & 0.0869 \\
\hline Wet mass of the sample, $\mathrm{g}$ & 0.2064 & 0.2051 & 0.209 & 0.2151 & 0.2128 & 0.2138 & 0.2155 & 0.2128 & 0.2176 & 0.2195 \\
\hline Volume of the sample (calculated), cm3 & 0.1484 & 0.1447 & 0.1458 & 0.1522 & 0.1465 & 0.1461 & 0.1480 & 0.1431 & 0.1487 & 0.1505 \\
\hline Pore volume or volume of the liquid, cm3 & 0.0450 & 0.0432 & 0.0487 & 0.0574 & 0.0541 & 0.0555 & 0.0580 & 0.0541 & 0.0610 & 0.0637 \\
\hline Porosity over volume, $\mathrm{cm} 3 / \mathrm{cm} 3$ & 0.3033 & 0.2982 & 0.3340 & 0.3770 & 0.3693 & 0.3801 & 0.3917 & 0.3781 & 0.4100 & 0.4229 \\
\hline
\end{tabular}




\begin{tabular}{|c|c|c|c|c|c|c|c|c|c|c|c|c|c|}
\hline Name of the Sample & Toray TG & $\mathrm{P}-\mathrm{H}-060$ & RAW & & & & & & & & & & \\
\hline Trial \# & 1 & 2 & 3 & 4 & 5 & 6 & 7 & 8 & 9 & 10 & & & \\
\hline Working liquid & Octane & & & & & & & & & & & & \\
\hline Density of the liquid, $\mathrm{cm} 3 / \mathrm{g}(25 \mathrm{C})$ & 0.7022 & 0.7022 & 0.7022 & 0.7022 & 0.7022 & 0.7022 & 0.7022 & 0.7022 & 0.7022 & 0.7022 & & & \\
\hline Surface tension, dine/cm (25C) & 21.75 & 21.75 & 21.75 & 21.75 & 21.75 & 21.75 & 21.75 & 21.75 & 21.75 & 21.75 & & & \\
\hline Mole volume, $\mathrm{cm} 3 / \mathrm{mol}(25 \mathrm{C})$ & 162.6 & 162.6 & 162.6 & 162.6 & 162.6 & 162.6 & 162.6 & 162.6 & 162.6 & 162.6 & & & \\
\hline Mass of the bottle for sample, $\mathrm{g}$ & 0 & 0 & 0 & 0 & 0 & 0 & 0 & 0 & 0 & 0 & & & \\
\hline Dry mass bottle+sample, $g$ & 0.0368 & 0.0368 & 0.0368 & 0.0368 & 0.0368 & 0.0368 & 0.0368 & 0.0368 & 0.0368 & 0.0368 & & & \\
\hline Mass sample in the liquid, $\mathrm{g}$ & 0.022 & 0.0233 & 0.0233 & 0.0229 & 0.0228 & 0.0231 & 0.0233 & 0.0231 & 0.0229 & 0.0234 & & & \\
\hline Wet mass bottle+sample, $g$ & 0.0844 & 0.0779 & 0.0803 & 0.0773 & 0.0769 & 0.0764 & 0.0751 & 0.076 & 0.078 & 0.0765 & & & \\
\hline Dry mass of the sample, $g$ & 0.0368 & 0.0368 & 0.0368 & 0.0368 & 0.0368 & 0.0368 & 0.0368 & 0.0368 & 0.0368 & 0.0368 & & & \\
\hline Volume of solid components, $\mathrm{cm} 3$ & 0.0211 & 0.0192 & 0.0192 & 0.0198 & 0.0199 & 0.0195 & 0.0192 & 0.0195 & 0.0198 & 0.0191 & & & \\
\hline Wet mass of the sample, $\mathrm{g}$ & 0.0844 & 0.0779 & 0.0803 & 0.0773 & 0.0769 & 0.0764 & 0.0751 & 0.076 & 0.078 & 0.0765 & & & \\
\hline Volume of the sample (calculated), cm3 & 0.0889 & 0.0778 & 0.0812 & 0.0775 & 0.0770 & 0.0759 & 0.0738 & 0.0753 & 0.0785 & 0.0756 & & & \\
\hline Pore volume or volume of the liquid, $\mathrm{cm} 3$ & 0.0678 & 0.0585 & 0.0619 & 0.0577 & 0.0571 & 0.0564 & 0.0545 & 0.0558 & 0.0587 & 0.0565 & avg & stdev & limit \\
\hline Porosity over volume, $\mathrm{cm} 3 / \mathrm{cm} 3$ & 0.7628 & 0.7527 & 0.7632 & 0.7445 & 0.7412 & 0.7430 & 0.7394 & 0.7410 & 0.7477 & 0.7476 & 0.7483 & 0.0087 & 0.006208 \\
\hline Porosity over weight, $\mathrm{cm} 3 / \mathrm{g}$ & 1.8420 & 1.5905 & 1.6834 & 1.5673 & 1.5518 & 1.5325 & 1.4821 & 1.5170 & 1.5944 & 1.5363 & & & \\
\hline Density of solid $\mathrm{g} / \mathrm{cm} 3$ & 1.7460 & 1.9141 & 1.9141 & 1.8591 & 1.8458 & 1.8862 & 1.9141 & 1.8862 & 1.8591 & 1.9284 & & & \\
\hline Density of the sample, $\mathrm{g} / \mathrm{cm} 3$ & 0.4141 & 0.4733 & 0.4534 & 0.4750 & 0.4777 & 0.4848 & 0.4989 & 0.4885 & 0.4690 & 0.4866 & & & \\
\hline Name of the Sample & Toray TGF & $-\mathrm{H}-060,3$ & $30 \%$ PTF & & & & & & & & & & \\
\hline Trial \# & \begin{tabular}{|l|}
1 \\
\end{tabular} & \begin{tabular}{l|l}
2 & \\
\end{tabular} & \begin{tabular}{l|l}
3 & \\
\end{tabular} & 4 & 5 & 6 & 7 & 8 & 9 & 10 & & & \\
\hline Working liquid & Octane & & & & & & & & & & & & \\
\hline Density of the liquid, $\mathrm{cm} 3 / \mathrm{g}(25 \mathrm{C})$ & \begin{tabular}{|l|}
0.7022 \\
\end{tabular} & 0.7022 & 0.7022 & 0.7022 & 0.7022 & 0.7022 & 0.7022 & 0.7022 & 0.7022 & 0.7022 & & & \\
\hline Surface tension, dine/cm (25C) & 21.75 & 21.75 & 21.75 & 21.75 & 21.75 & 21.75 & 21.75 & 21.75 & 21.75 & 21.75 & & & \\
\hline Mole volume, $\mathrm{cm} 3 / \mathrm{mol}(25 \mathrm{C})$ & 162.6 & 162.6 & 162.6 & 162.6 & 162.6 & 162.6 & 162.6 & 162.6 & 162.6 & 162.6 & & & \\
\hline Mass of the bottle for sample, $\mathrm{g}$ & 0 & 0 & 0 & 0 & 0 & 0 & 0 & 0 & 0 & 0 & & & \\
\hline Dry mass bottle+sample, $\mathrm{g}$ & 0.0507 & 0.0507 & 0.0507 & 0.0507 & 0.0507 & 0.0507 & 0.0507 & 0.0507 & 0.0507 & 0.0507 & & & \\
\hline Mass sample in the liquid, $g$ & 0.0313 & 0.0314 & 0.0324 & 0.0326 & 0.0329 & 0.033 & 0.0327 & 0.0328 & 0.0321 & 0.0321 & & & \\
\hline Wet mass bottle+sample, $g$ & 0.0857 & 0.0803 & 0.0832 & 0.0839 & 0.082 & 0.0832 & 0.0838 & 0.0847 & 0.0869 & 0.0856 & & & \\
\hline Dry mass of the sample, $\mathrm{g}$ & 0.0507 & 0.0507 & 0.0507 & 0.0507 & 0.0507 & 0.0507 & 0.0507 & 0.0507 & 0.0507 & 0.0507 & & & \\
\hline Volume of solid components, $\mathrm{cm} 3$ & 0.0276 & 0.0275 & 0.0261 & 0.0258 & 0.0253 & 0.0252 & 0.0256 & 0.0255 & 0.0265 & 0.0265 & & & \\
\hline Wet mass of the sample, $\mathrm{g}$ & 0.0857 & 0.0803 & 0.0832 & 0.0839 & 0.082 & 0.0832 & 0.0838 & 0.0847 & 0.0869 & 0.0856 & & & \\
\hline Volume of the sample (calculated), cm3 & 0.0775 & 0.0696 & 0.0723 & 0.0731 & 0.0699 & 0.0715 & 0.0728 & 0.0739 & 0.0780 & 0.0762 & & & \\
\hline Pore volume or volume of the liquid, $\mathrm{cm} 3$ & 0.0498 & 0.0422 & 0.0463 & 0.0473 & 0.0446 & 0.0463 & 0.0471 & 0.0484 & 0.0516 & 0.0497 & avg & stdev & limit \\
\hline Porosity over volume, $\mathrm{cm} 3 / \mathrm{cm} 3$ & 0.6434 & 0.6053 & 0.6398 & 0.6472 & 0.6375 & 0.6474 & 0.6477 & 0.6551 & 0.6606 & 0.6523 & 0.6436 & 0.0151 & 0.010821 \\
\hline Porosity over weight, $\mathrm{cm} 3 / \mathrm{g}$ & 0.9831 & 0.8314 & 0.9129 & 0.9325 & 0.8792 & 0.9129 & 0.9297 & 0.9550 & 1.0168 & 0.9803 & & & \\
\hline Density of solid $\mathrm{g} / \mathrm{cm} 3$ & 1.8351 & 1.8446 & 1.9454 & 1.9669 & 2.0001 & 2.0114 & 1.9779 & 1.9889 & 1.9141 & 1.9141 & & & \\
\hline Density of the sample, $\mathrm{g} / \mathrm{cm} 3$ & 0.6544 & 0.7280 & 0.7008 & 0.6940 & 0.7251 & 0.7092 & 0.6967 & 0.6860 & 0.6497 & 0.6654 & & & \\
\hline
\end{tabular}




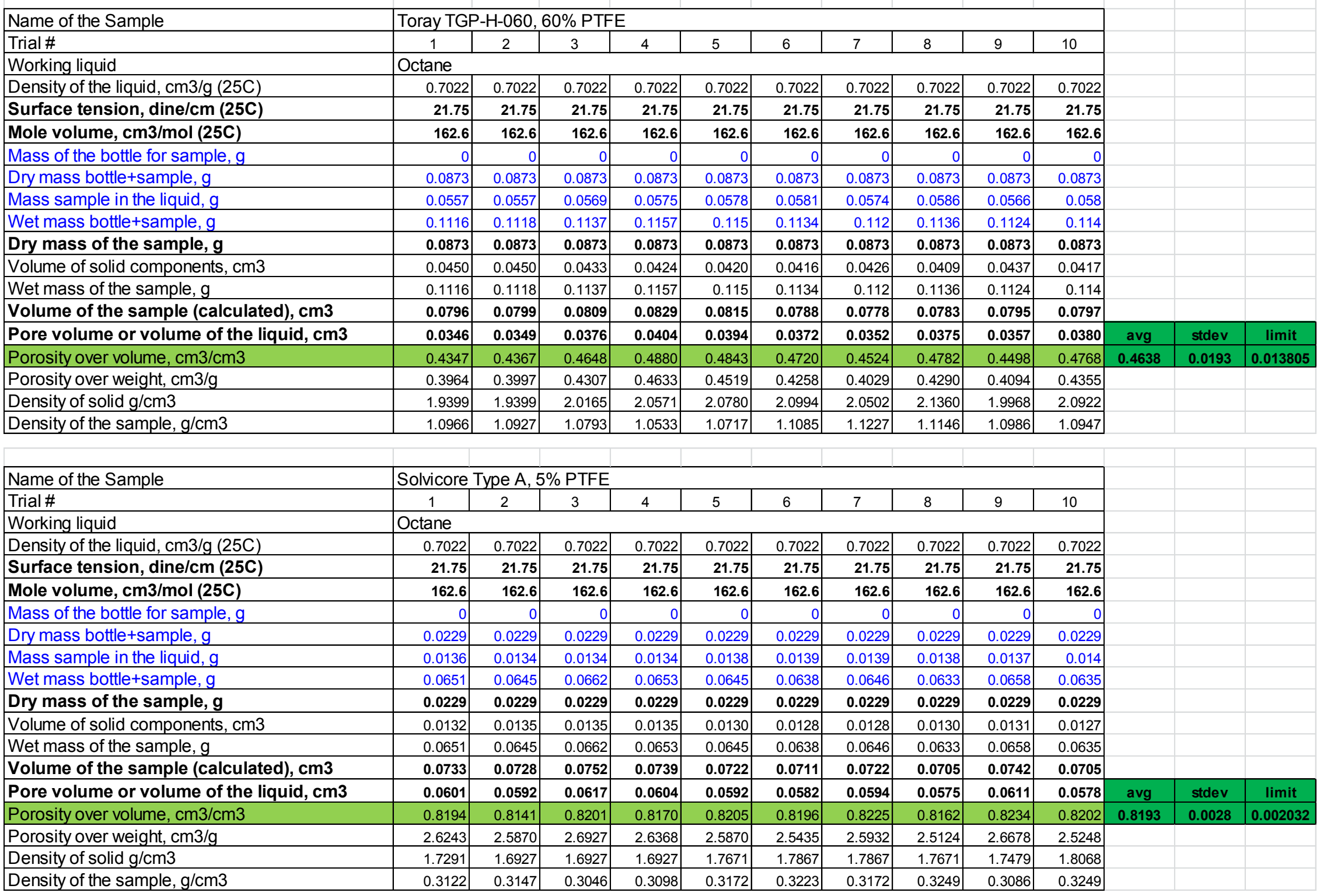




\begin{tabular}{|c|c|c|c|c|c|c|c|c|c|c|c|c|c|}
\hline Name of the Sample & Solvicore 7 & ype A, N & & & & & & & & & & & \\
\hline Trial \# & \begin{tabular}{|l|l}
1 & \\
\end{tabular} & 2 & 3 & 4 & 5 & 6 & 7 & 8 & 9 & 10 & & & \\
\hline Working liquid & Octane & & & & & & & & & & & & \\
\hline Density of the liquid, $\mathrm{cm} 3 / \mathrm{g}(25 \mathrm{C})$ & 0.7022 & 0.7022 & 0.7022 & 0.7022 & 0.7022 & 0.7022 & 0.7022 & 0.7022 & 0.7022 & 0.7022 & & & \\
\hline Surface tension, dine/cm (25C) & 21.75 & 21.75 & 21.75 & 21.75 & 21.75 & 21.75 & 21.75 & 21.75 & 21.75 & 21.75 & & & \\
\hline Mole volume, $\mathrm{cm} 3 / \mathrm{mol}(25 \mathrm{C})$ & 162.6 & 162.6 & 162.6 & 162.6 & 162.6 & 162.6 & 162.6 & 162.6 & 162.6 & 162.6 & & & \\
\hline Mass of the bottle for sample, $\mathrm{g}$ & 0 & 0 & 0 & 0 & 0 & 0 & 0 & 0 & 0 & 0 & & & \\
\hline Dry mass bottle+sample, $\mathrm{g}$ & 0.0457 & 0.0457 & 0.0457 & 0.0457 & 0.0457 & 0.0457 & 0.0457 & 0.0457 & 0.0457 & 0.0457 & & & \\
\hline Mass sample in the liquid, $g$ & 0.0258 & 0.0254 & 0.0274 & 0.0282 & 0.0282 & 0.0283 & 0.0285 & 0.0286 & 0.0283 & 0.0283 & & & \\
\hline Wet mass bottle+sample, $g$ & 0.1018 & 0.0979 & 0.0993 & 0.0999 & 0.1017 & 0.0988 & 0.1007 & 0.0978 & 0.099 & 0.1 & & & \\
\hline Dry mass of the sample, $g$ & 0.0457 & 0.0457 & 0.0457 & 0.0457 & 0.0457 & 0.0457 & 0.0457 & 0.0457 & 0.0457 & 0.0457 & & & \\
\hline Volume of solid components, $\mathrm{cm} 3$ & 0.0283 & 0.0289 & 0.0261 & 0.0249 & 0.0249 & 0.0248 & 0.0245 & 0.0244 & 0.0248 & 0.0248 & & & \\
\hline Wet mass of the sample, $\mathrm{g}$ & 0.1018 & 0.0979 & 0.0993 & 0.0999 & 0.1017 & 0.0988 & 0.1007 & 0.0978 & 0.099 & 0.1 & & & \\
\hline Volume of the sample (calculated), cm3 & 0.1082 & 0.1032 & 0.1024 & 0.1021 & 0.1047 & 0.1004 & 0.1028 & 0.0985 & 0.1007 & 0.1021 & & & \\
\hline Pore volume or volume of the liquid, $\mathrm{cm} 3$ & 0.0799 & 0.0743 & 0.0763 & 0.0772 & 0.0797 & 0.0756 & 0.0783 & 0.0742 & 0.0759 & 0.0773 & avg & stdev & limit \\
\hline Porosity over volume, $\mathrm{cm} 3 / \mathrm{cm} 3$ & 0.7382 & 0.7200 & 0.7455 & 0.7559 & 0.7619 & 0.7532 & 0.7618 & 0.7529 & 0.7539 & 0.7573 & 0.7501 & 0.0128 & 0.009121 \\
\hline Porosity over weight, $\mathrm{cm} 3 / \mathrm{g}$ & 1.7482 & 1.6266 & 1.6703 & 1.6890 & 1.7451 & 1.6547 & 1.7139 & 1.6235 & 1.6609 & 1.6921 & & & \\
\hline Density of solid $\mathrm{g} / \mathrm{cm} 3$ & 1.6126 & 1.5808 & 1.7536 & 1.8337 & 1.8337 & 1.8443 & 1.8657 & 1.8766 & 1.8443 & 1.8443 & & & \\
\hline Density of the sample, $\mathrm{g} / \mathrm{cm} 3$ & 0.4222 & 0.4426 & 0.4463 & 0.4476 & 0.4366 & 0.4552 & 0.4445 & 0.4637 & 0.4539 & 0.4476 & & & \\
\hline Name of the Sample & Solvicore 7 & ype B, N & & & & & & & & & & & \\
\hline Trial \# & \begin{tabular}{|l|}
1 \\
\end{tabular} & 2 & 3 & 4 & 5 & 6 & 7 & 8 & 9 & 10 & & & \\
\hline Working liquid & Octane & & & & & & & & & & & & \\
\hline Density of the liquid, $\mathrm{cm} 3 / \mathrm{g}(25 \mathrm{C})$ & 0.7022 & 0.7022 & 0.7022 & 0.7022 & 0.7022 & 0.7022 & 0.7022 & 0.7022 & 0.7022 & 0.7022 & & & \\
\hline Surface tension, dine/cm (25C) & 21.75 & 21.75 & 21.75 & 21.75 & 21.75 & 21.75 & 21.75 & 21.75 & 21.75 & 21.75 & & & \\
\hline Mole volume, cm3/mol (25C) & 162.6 & 162.6 & 162.6 & 162.6 & 162.6 & 162.6 & 162.6 & 162.6 & 162.6 & 162.6 & & & \\
\hline Mass of the bottle for sample, $\mathrm{g}$ & 0 & 0 & 0 & 0 & 0 & 0 & 0 & 0 & 0 & 0 & & & \\
\hline Dry mass bottle+sample, $\mathrm{g}$ & 0.0352 & 0.0352 & 0.0352 & 0.0352 & 0.0352 & 0.0352 & 0.0352 & 0.0352 & 0.0352 & 0.0352 & & & \\
\hline Mass sample in the liquid, $g$ & 0.0169 & 0.0216 & 0.0214 & 0.0217 & 0.0217 & 0.0218 & 0.0212 & 0.0214 & 0.0211 & 0.0216 & & & \\
\hline Wet mass bottle+sample, $\mathrm{g}$ & 0.0826 & 0.0807 & 0.0814 & 0.0801 & 0.0828 & 0.0812 & 0.079 & 0.0826 & 0.0823 & 0.0801 & & & \\
\hline Dry mass of the sample, $g$ & 0.0352 & 0.0352 & 0.0352 & 0.0352 & 0.0352 & 0.0352 & 0.0352 & 0.0352 & 0.0352 & 0.0352 & & & \\
\hline Volume of solid components, $\mathrm{cm} 3$ & 0.0261 & 0.0194 & 0.0197 & 0.0192 & 0.0192 & 0.0191 & 0.0199 & 0.0197 & 0.0201 & 0.0194 & & & \\
\hline Wet mass of the sample, $\mathrm{g}$ & 0.0826 & 0.0807 & 0.0814 & 0.0801 & 0.0828 & 0.0812 & 0.079 & 0.0826 & 0.0823 & 0.0801 & & & \\
\hline Volume of the sample (calculated), cm3 & 0.0936 & 0.0842 & 0.0854 & 0.0832 & 0.0870 & 0.0846 & 0.0823 & 0.0872 & 0.0872 & 0.0833 & & & \\
\hline Pore volume or volume of the liquid, $\mathrm{cm} 3$ & 0.0675 & 0.0648 & 0.0658 & 0.0639 & 0.0678 & 0.0655 & 0.0624 & 0.0675 & 0.0671 & 0.0639 & avg & stdev & limit \\
\hline Porosity over volume, $\mathrm{cm} 3 / \mathrm{cm} 3$ & 0.7215 & 0.7699 & 0.7700 & 0.7688 & 0.7791 & 0.7744 & 0.7578 & 0.7745 & 0.7696 & 0.7675 & 0.7653 & 0.0164 & 0.011716 \\
\hline Porosity over weight, $\mathrm{cm} 3 / \mathrm{g}$ & 1.9177 & 1.8408 & 1.8691 & 1.8165 & 1.9258 & 1.8610 & 1.7720 & 1.9177 & 1.9055 & 1.8165 & & & \\
\hline Density of solid $\mathrm{g} / \mathrm{cm} 3$ & 1.3507 & 1.8175 & 1.7911 & 1.8309 & 1.8309 & 1.8446 & 1.7655 & 1.7911 & 1.7530 & 1.8175 & & & \\
\hline Density of the sample, $\mathrm{g} / \mathrm{cm} 3$ & 0.3762 & 0.4182 & 0.4120 & 0.4232 & 0.4045 & 0.4161 & 0.4276 & 0.4039 & 0.4039 & 0.4225 & & & \\
\hline
\end{tabular}




\begin{tabular}{|c|c|c|c|c|c|c|c|c|c|c|c|c|c|}
\hline Name of the Sample & SGL $10 \mathrm{~A}$ & & & & & & & & & & & & \\
\hline Trial \# & \begin{tabular}{|l|l}
1 & \\
\end{tabular} & 2 & 3 & 4 & 5 & 6 & 7 & 8 & 9 & 10 & & & \\
\hline Working liquid & Octane & & & & & & & & & & & & \\
\hline Density of the liquid, $\mathrm{cm} 3 / \mathrm{g}(25 \mathrm{C})$ & 0.7022 & 0.7022 & 0.7022 & 0.7022 & 0.7022 & 0.7022 & 0.7022 & 0.7022 & 0.7022 & 0.7022 & & & \\
\hline Surface tension, dine/cm (25C) & 21.75 & 21.75 & 21.75 & 21.75 & 21.75 & 21.75 & 21.75 & 21.75 & 21.75 & 21.75 & & & \\
\hline Mole volume, $\mathrm{cm} 3 / \mathrm{mol}(25 \mathrm{C})$ & 162.6 & 162.6 & 162.6 & 162.6 & 162.6 & 162.6 & 162.6 & 162.6 & 162.6 & 162.6 & & & \\
\hline Mass of the bottle for sample, $\mathrm{g}$ & 0 & 0 & 0 & 0 & 0 & 0 & 0 & 0 & 0 & 0 & & & \\
\hline Dry mass bottle+sample, $\mathrm{g}$ & 0.0372 & 0.0372 & 0.0372 & 0.0372 & 0.0372 & 0.0372 & 0.0372 & 0.0372 & 0.0372 & 0.0372 & & & \\
\hline Mass sample in the liquid, $g$ & 0.0209 & 0.0217 & 0.0213 & 0.0215 & 0.0205 & 0.0214 & 0.0214 & 0.0216 & 0.0214 & 0.0213 & & & \\
\hline Wet mass bottle+sample, $g$ & 0.1256 & 0.1234 & 0.1227 & 0.1216 & 0.1213 & 0.1213 & 0.1216 & 0.1207 & 0.1203 & 0.1201 & & & \\
\hline Dry mass of the sample, $g$ & 0.0372 & 0.0372 & 0.0372 & 0.0372 & 0.0372 & 0.0372 & 0.0372 & 0.0372 & 0.0372 & 0.0372 & & & \\
\hline Volume of solid components, $\mathrm{cm} 3$ & 0.0232 & 0.0221 & 0.0226 & 0.0224 & 0.0238 & 0.0225 & 0.0225 & 0.0222 & 0.0225 & 0.0226 & & & \\
\hline Wet mass of the sample, $\mathrm{g}$ & 0.1256 & 0.1234 & 0.1227 & 0.1216 & 0.1213 & 0.1213 & 0.1216 & 0.1207 & 0.1203 & 0.1201 & & & \\
\hline Volume of the sample (calculated), cm3 & 0.1491 & 0.1448 & 0.1444 & 0.1426 & 0.1435 & 0.1423 & 0.1427 & 0.1411 & 0.1408 & 0.1407 & & & \\
\hline Pore volume or volume of the liquid, $\mathrm{cm} 3$ & 0.1259 & 0.1228 & 0.1218 & 0.1202 & 0.1198 & 0.1198 & 0.1202 & 0.1189 & 0.1183 & 0.1181 & avg & stdev & limit \\
\hline Porosity over volume, $\mathrm{cm} 3 / \mathrm{cm} 3$ & 0.8443 & 0.8476 & 0.8432 & 0.8432 & 0.8343 & 0.8418 & 0.8423 & 0.8426 & 0.8402 & 0.8391 & 0.8419 & 0.0035 & 0.002504 \\
\hline Porosity over weight, $\mathrm{cm} 3 / \mathrm{g}$ & 3.3841 & 3.2999 & 3.2731 & 3.2310 & 3.2195 & 3.2195 & 3.2310 & 3.1966 & 3.1812 & 3.1736 & & & \\
\hline Density of solid $\mathrm{g} / \mathrm{cm} 3$ & 1.6026 & 1.6853 & 1.6429 & 1.6638 & 1.5642 & 1.6533 & 1.6533 & 1.6745 & 1.6533 & 1.6429 & & & \\
\hline Density of the sample, $\mathrm{g} / \mathrm{cm} 3$ & 0.2495 & 0.2569 & 0.2576 & 0.2610 & 0.2591 & 0.2615 & 0.2607 & 0.2636 & 0.2641 & 0.2644 & & & \\
\hline Name of the Sample & SGL $10 \mathrm{BR}$ & & & & & & & & & & & & \\
\hline Trial \# & \begin{tabular}{|l|}
1 \\
\end{tabular} & 2 & 3 & 4 & 5 & 6 & 7 & 8 & 9 & 10 & & & \\
\hline Working liquid & Octane & & & & & & & & & & & & \\
\hline Density of the liquid, $\mathrm{cm} 3 / \mathrm{g}(25 \mathrm{C})$ & 0.7022 & 0.7022 & 0.7022 & 0.7022 & 0.7022 & 0.7022 & 0.7022 & 0.7022 & 0.7022 & 0.7022 & & & \\
\hline Surface tension, dine/cm (25C) & 21.75 & 21.75 & 21.75 & 21.75 & 21.75 & 21.75 & 21.75 & 21.75 & 21.75 & 21.75 & & & \\
\hline Mole volume, cm3/mol (25C) & 162.6 & 162.6 & 162.6 & 162.6 & 162.6 & 162.6 & 162.6 & 162.6 & 162.6 & 162.6 & & & \\
\hline Mass of the bottle for sample, $\mathrm{g}$ & 0 & 0 & 0 & 0 & 0 & 0 & 0 & 0 & 0 & 0 & & & \\
\hline Dry mass bottle+sample, $\mathrm{g}$ & 0.0398 & 0.0398 & 0.0398 & 0.0398 & 0.0398 & 0.0398 & 0.0398 & 0.0398 & 0.0398 & 0.0398 & & & \\
\hline Mass sample in the liquid, $g$ & 0.0222 & 0.0234 & 0.0238 & 0.0236 & 0.024 & 0.0232 & 0.0233 & 0.0223 & 0.0228 & 0.023 & & & \\
\hline Wet mass bottle+sample, $\mathrm{g}$ & 0.1138 & 0.1154 & 0.1152 & 0.115 & 0.1142 & 0.1161 & 0.1153 & 0.1156 & 0.1142 & 0.1128 & & & \\
\hline Dry mass of the sample, $g$ & 0.0398 & 0.0398 & 0.0398 & 0.0398 & 0.0398 & 0.0398 & 0.0398 & 0.0398 & 0.0398 & 0.0398 & & & \\
\hline Volume of solid components, $\mathrm{cm} 3$ & 0.0251 & 0.0234 & 0.0228 & 0.0231 & 0.0225 & 0.0236 & 0.0235 & 0.0249 & 0.0242 & 0.0239 & & & \\
\hline Wet mass of the sample, $\mathrm{g}$ & 0.1138 & 0.1154 & 0.1152 & 0.115 & 0.1142 & 0.1161 & 0.1153 & 0.1156 & 0.1142 & 0.1128 & & & \\
\hline Volume of the sample (calculated), cm3 & 0.1304 & 0.1310 & 0.1302 & 0.1302 & 0.1285 & 0.1323 & 0.1310 & 0.1329 & 0.1302 & 0.1279 & & & \\
\hline Pore volume or volume of the liquid, cm3 & 0.1054 & 0.1077 & 0.1074 & 0.1071 & 0.1060 & 0.1087 & 0.1075 & 0.1079 & 0.1060 & 0.1040 & avg & stdev & limit \\
\hline Porosity over volume, $\mathrm{cm} 3 / \mathrm{cm} 3$ & 0.8079 & 0.8217 & 0.8249 & 0.8228 & 0.8248 & 0.8213 & 0.8207 & 0.8124 & 0.8140 & 0.8129 & 0.8183 & 0.0060 & 0.004292 \\
\hline Porosity over weight, $\mathrm{cm} 3 / \mathrm{g}$ & 2.6478 & 2.7051 & 2.6979 & 2.6908 & 2.6621 & 2.7301 & 2.7015 & 2.7122 & 2.6621 & 2.6120 & & & \\
\hline Density of solid $\mathrm{g} / \mathrm{cm} 3$ & 1.5879 & 1.7041 & 1.7467 & 1.7252 & 1.7688 & 1.6836 & 1.6938 & 1.5970 & 1.6440 & 1.6635 & & & \\
\hline Density of the sample, $\mathrm{g} / \mathrm{cm} 3$ & 0.3051 & 0.3038 & 0.3058 & 0.3058 & 0.3098 & 0.3008 & 0.3038 & 0.2995 & 0.3058 & 0.3112 & & & \\
\hline
\end{tabular}




\begin{tabular}{|c|c|c|c|c|c|c|c|c|c|c|c|c|c|}
\hline \multirow{2}{*}{$\begin{array}{l}\text { Name of the Sample } \\
\text { Trial \# }\end{array}$} & \multicolumn{10}{|c|}{ SGL $25 \mathrm{DC}$} & & & \\
\hline & \begin{tabular}{|l|}
1 \\
\end{tabular} & 2 & 3 & 4 & 5 & 6 & 7 & 8 & 9 & 10 & & & \\
\hline Working liquid & \multicolumn{10}{|l|}{ Octane } & & & \\
\hline Density of the liquid, $\mathrm{cm} 3 / \mathrm{g}(25 \mathrm{C})$ & \begin{tabular}{|l|}
0.7022 \\
\end{tabular} & 0.7022 & 0.7022 & 0.7022 & 0.7022 & 0.7022 & 0.7022 & 0.7022 & 0.7022 & 0.7022 & & & \\
\hline Surface tension, dine/cm (25C) & 21.75 & 21.75 & 21.75 & 21.75 & 21.75 & 21.75 & 21.75 & 21.75 & 21.75 & 21.75 & & & \\
\hline Mole volume, $\mathrm{cm} 3 / \mathrm{mol}(25 \mathrm{C})$ & 162.6 & 162.6 & 162.6 & 162.6 & 162.6 & 162.6 & 162.6 & 162.6 & 162.6 & 162.6 & & & \\
\hline Mass of the bottle for sample, $\mathrm{g}$ & 0 & 0 & 0 & 0 & 0 & 0 & 0 & 0 & 0 & 0 & & & \\
\hline Dry mass bottle+sample, $g$ & 0.0396 & 0.0396 & 0.0396 & 0.0396 & 0.0396 & 0.0396 & 0.0396 & 0.0396 & 0.0396 & 0.0396 & & & \\
\hline Mass sample in the liquid, $g$ & 0.0233 & 0.024 & 0.0243 & 0.0241 & 0.0242 & 0.0238 & 0.0242 & 0.0242 & 0.0246 & 0.0242 & & & \\
\hline Wet mass bottle+sample, $\mathrm{g}$ & 0.0912 & 0.091 & 0.0915 & 0.0903 & 0.0903 & 0.0911 & 0.0909 & 0.0923 & 0.09 & 0.0915 & & & \\
\hline Dry mass of the sample, $\mathrm{g}$ & 0.0396 & 0.0396 & 0.0396 & 0.0396 & 0.0396 & 0.0396 & 0.0396 & 0.0396 & 0.0396 & 0.0396 & & & \\
\hline Volume of solid components, $\mathrm{cm} 3$ & 0.0232 & 0.0222 & 0.0218 & 0.0221 & 0.0219 & 0.0225 & 0.0219 & 0.0219 & 0.0214 & 0.0219 & & & \\
\hline Wet mass of the sample, $g$ & 0.0912 & 0.091 & 0.0915 & 0.0903 & 0.0903 & 0.0911 & 0.0909 & 0.0923 & 0.09 & 0.0915 & & & \\
\hline Volume of the sample (calculated), cm3 & 0.0967 & 0.0954 & 0.0957 & 0.0943 & 0.0941 & 0.0958 & 0.0950 & 0.0970 & 0.0931 & 0.0958 & & & \\
\hline Pore volume or volume of the liquid, $\mathrm{cm} 3$ & 0.0735 & 0.0732 & 0.0739 & 0.0722 & 0.0722 & 0.0733 & 0.0731 & 0.0750 & 0.0718 & 0.0739 & avg & stdev & limit \\
\hline Porosity over volume, $\mathrm{cm} 3 / \mathrm{cm} 3$ & 0.7599 & 0.7672 & 0.7723 & 0.7659 & 0.7670 & 0.7652 & 0.7691 & 0.7739 & 0.7706 & 0.7712 & 0.7682 & 0.0041 & 0.002917 \\
\hline Porosity over weight, $\mathrm{cm} 3 / \mathrm{g}$ & 1.8556 & 1.8484 & 1.8664 & 1.8233 & 1.8233 & 1.8520 & 1.8449 & 1.8952 & 1.8125 & 1.8664 & & & \\
\hline Density of solid $\mathrm{g} / \mathrm{cm} 3$ & 1.7060 & 1.7825 & 1.8175 & 1.7940 & 1.8057 & 1.7599 & 1.8057 & 1.8057 & 1.8538 & 1.8057 & & & \\
\hline Density of the sample, $\mathrm{g} / \mathrm{cm} 3$ & 0.4095 & 0.4150 & 0.4138 & 0.4200 & 0.4207 & 0.4132 & 0.4169 & 0.4083 & 0.4252 & 0.4132 & & & \\
\hline
\end{tabular}




\section{Appendix E}

\section{Effective Diffusion Coefficient Measurements}

\begin{tabular}{|c|c|c|c|c|c|c|c|c|}
\hline & Toray TGP-H-120 & & & & & & & \\
\hline & Porosity & $70.9 \%$ & $+/-0.8 \%$ & & & & & \\
\hline & GDL thickness (m) & 0.00037 & $+/-0.00001$ & & & & & \\
\hline & Sensor Distance (m) & 0.0265 & & & & & & \\
\hline $\mathbf{N}$ & Trial & $\mathrm{D}_{\text {eq }}$ & $\begin{array}{c}\text { Average } \\
\text { Temperature } \\
\left({ }^{\circ} \mathrm{C}\right) \\
\end{array}$ & $\begin{array}{c}\text { Average } \\
\text { Pressure }(\mathrm{kPa})\end{array}$ & $\begin{array}{l}\text { Literature } \\
\text { Value }\end{array}$ & $D_{\text {eff }}$ & Q & $\tau_{\max }$ \\
\hline 1 & Jan11_5 & $2.11 \mathrm{E}-05$ & 23.9 & 96.1 & $2.184 \mathrm{E}-05$ & $6.34 \mathrm{E}-06$ & 0.29 & 0.711 \\
\hline 2 & Jan11_6 & $2.10 \mathrm{E}-05$ & 23.7 & 96.0 & 2.183E-05 & $5.46 \mathrm{E}-06$ & 0.25 & 0.186 \\
\hline 3 & Jan11_7 & $2.06 \mathrm{E}-05$ & 23.6 & 95.9 & $2.184 \mathrm{E}-05$ & 4.17E-06 & 0.19 & 1.492 \\
\hline 4 & Jan11_8 & $2.11 \mathrm{E}-05$ & 23.6 & 95.9 & $2.186 \mathrm{E}-05$ & $6.00 \mathrm{E}-06$ & 0.27 & 0.355 \\
\hline 5 & Jan11_9 & $2.08 \mathrm{E}-05$ & 23.6 & 95.8 & $2.186 \mathrm{E}-05$ & 4.89E-06 & 0.22 & 0.772 \\
\hline 6 & Jan10_5 & $2.11 \mathrm{E}-05$ & 23.6 & 96.8 & $2.164 \mathrm{E}-05$ & $7.36 \mathrm{E}-06$ & 0.34 & 1.809 \\
\hline 7 & Jan10_6 & 2.10E-05 & 23.5 & 96.8 & $2.163 \mathrm{E}-05$ & $6.99 \mathrm{E}-06$ & 0.32 & 1.431 \\
\hline 8 & $\operatorname{Jan} 25 \_6$ & $2.08 \mathrm{E}-05$ & 22.8 & 95.8 & $2.176 \mathrm{E}-05$ & 5.01E-06 & 0.23 & 0.624 \\
\hline 9 & Jan25_7 & $2.08 \mathrm{E}-05$ & 22.9 & 95.8 & 2.177E-05 & $4.98 \mathrm{E}-06$ & 0.23 & 0.655 \\
\hline 10 & $\operatorname{Jan} 25 \_8$ & $2.08 \mathrm{E}-05$ & 22.9 & 95.9 & $2.176 \mathrm{E}-05$ & $5.25 \mathrm{E}-06$ & 0.24 & 0.383 \\
\hline 11 & Jan25_9 & 2.07E-05 & 22.9 & 95.9 & 2.175E-05 & 4.76E-06 & 0.22 & 0.874 \\
\hline \multirow[t]{4}{*}{12} & Jan25_10 & $2.10 \mathrm{E}-05$ & 22.9 & 95.9 & \begin{tabular}{|l}
$2.175 E-05$ \\
\end{tabular} & $6.29 \mathrm{E}-06$ & 0.29 & 0.681 \\
\hline & & & & & Average & $5.62 \mathrm{E}-06$ & 0.26 & \\
\hline & & & & & Std. Dev. & $9.68 \mathrm{E}-07$ & 0.045 & \\
\hline & & & & & 95\% C.I. & $6.2 \mathrm{E}-07$ & 0.029 & \\
\hline
\end{tabular}

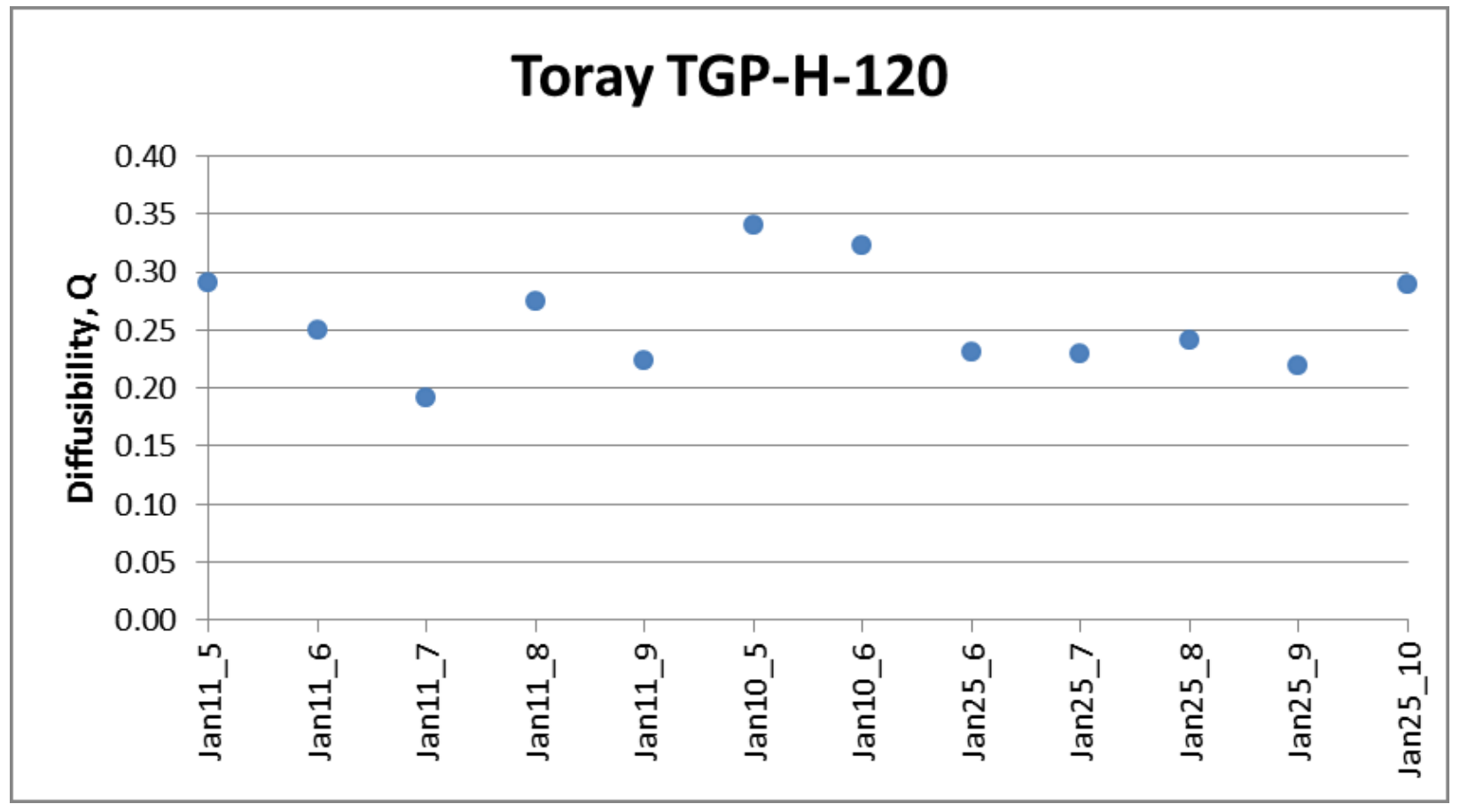




\begin{tabular}{|c|c|c|c|c|c|c|c|c|}
\hline & \multicolumn{2}{|c|}{ Toray TGP-H-120 30\% wet proofing } & \multirow[b]{2}{*}{$+/-1.5 \%$} & & & & & \\
\hline & Porosity & $61.77 \%$ & & & & & & \\
\hline & GDL thickness (m) & 0.0004 & $+/-0.00001$ & & & & & \\
\hline & Sensor Distance (m) & 0.0265 & & & & & & \\
\hline $\mathbf{N}$ & Trial & $D_{\text {eq }}$ & \begin{tabular}{|c|} 
Average \\
Temperature \\
$\left({ }^{\circ} \mathrm{C}\right)$ \\
\end{tabular} & $\begin{array}{c}\text { Average } \\
\text { Pressure }(\mathrm{kPa})\end{array}$ & $\begin{array}{l}\text { Literature } \\
\text { Value }\end{array}$ & $D_{\text {eff }}$ & $Q$ & $\tau_{\max }$ \\
\hline 1 & $\operatorname{Jan} 12 \_5$ & 2.09E-05 & 24.4 & 95.8 & 2.197E-05 & $4.81 \mathrm{E}-06$ & 0.22 & 1.211 \\
\hline 2 & $\operatorname{Jan} 12 \_6$ & 2.09E-05 & 24.3 & 95.8 & $2.196 \mathrm{E}-05$ & $5.15 \mathrm{E}-06$ & 0.23 & 1.524 \\
\hline 3 & $\operatorname{Jan} 12 \_7$ & $2.10 \mathrm{E}-05$ & 24.2 & 95.8 & $2.195 \mathrm{E}-05$ & $5.39 E-06$ & 0.25 & 1.751 \\
\hline 4 & Jan19_7 & $1.93 \mathrm{E}-05$ & 23.4 & 95.3 & $2.195 \mathrm{E}-05$ & $2.15 \mathrm{E}-06$ & 0.10 & 1.252 \\
\hline 5 & Jan19_8 & 1.95E-05 & 23.4 & 95.3 & $2.196 \mathrm{E}-05$ & $2.39 \mathrm{E}-06$ & 0.11 & 1.031 \\
\hline 6 & Jan19_9 & $1.97 \mathrm{E}-05$ & 23.5 & 95.3 & 2.197E-05 & $2.58 \mathrm{E}-06$ & 0.12 & 0.852 \\
\hline 7 & Jan21_9 & $2.00 \mathrm{E}-05$ & 23.5 & 95.1 & $2.202 \mathrm{E}-05$ & $2.84 \mathrm{E}-06$ & 0.13 & 0.622 \\
\hline 8 & Jan21_10 & $2.01 \mathrm{E}-05$ & 23.5 & 95.1 & $2.201 \mathrm{E}-05$ & 2.99E-06 & 0.14 & 0.481 \\
\hline 9 & Jan21_11 & $2.03 \mathrm{E}-05$ & 23.5 & 95.2 & $2.200 \mathrm{E}-05$ & $3.44 \mathrm{E}-06$ & 0.16 & 0.063 \\
\hline 10 & Feb01_14 & 1.99E-05 & 22.4 & 96.5 & $2.156 \mathrm{E}-05$ & 3.37E-06 & 0.16 & 0.066 \\
\hline 11 & Feb01_15 & $1.98 \mathrm{E}-05$ & 22.4 & 96.5 & $2.156 \mathrm{E}-05$ & $3.08 \mathrm{E}-06$ & 0.14 & 0.335 \\
\hline 12 & Feb01_16 & $2.01 \mathrm{E}-05$ & 22.4 & 96.5 & $2.156 \mathrm{E}-05$ & 3.67E-06 & 0.17 & 0.216 \\
\hline & & & & & Average & $3.49 \mathrm{E}-06$ & 0.16 & \\
\hline & & & & & Std. Dev. & $1.08 \mathrm{E}-06$ & 0.049 & \\
\hline & & & & & 95\% C.I. & $6.9 \mathrm{E}-07$ & 0.031 & \\
\hline
\end{tabular}

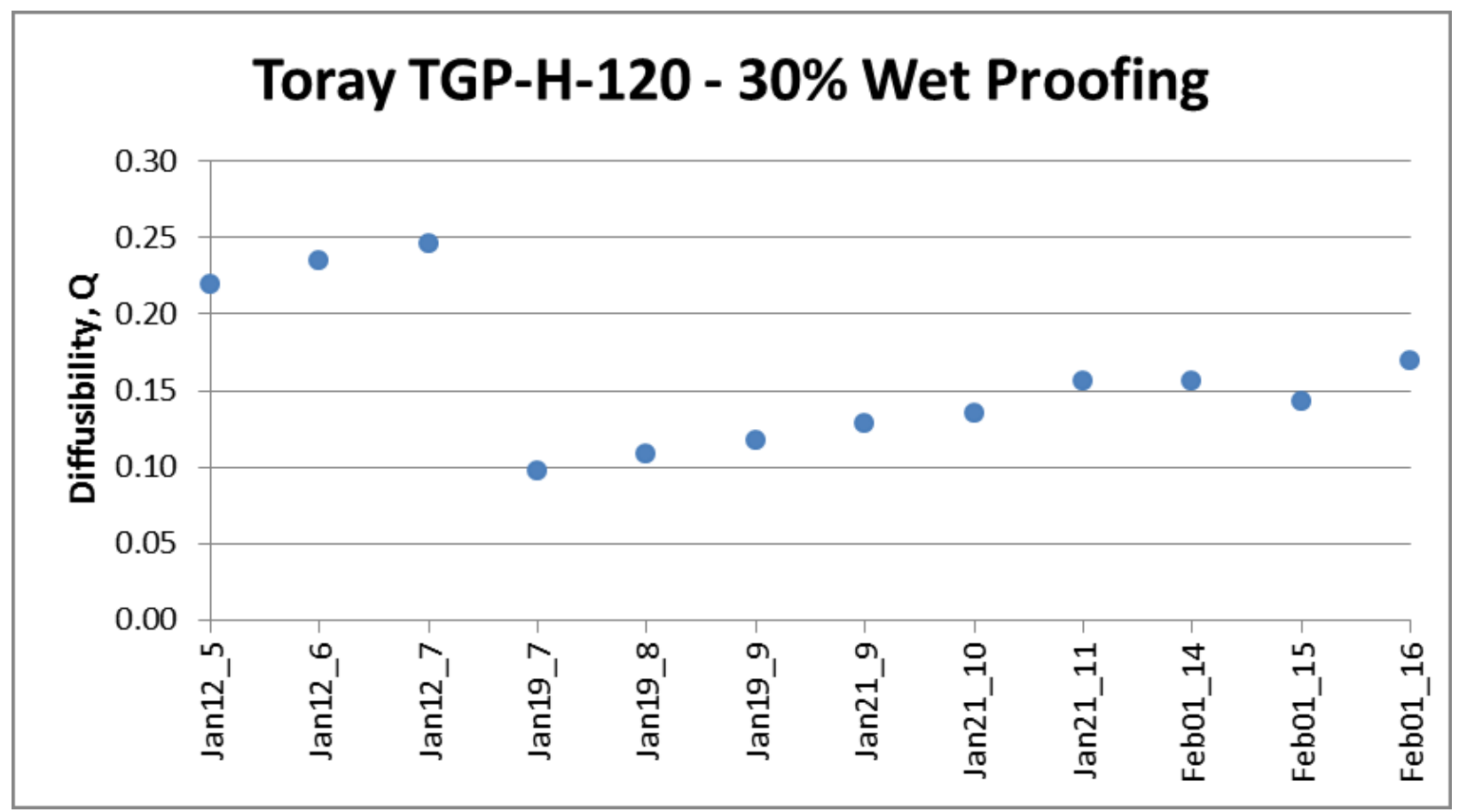




\begin{tabular}{|c|c|c|c|c|c|c|c|c|}
\hline & \multicolumn{2}{|c|}{ Toray TGP-H-120 $60 \%$ wet proofing } & \multirow[b]{2}{*}{$+/-3 \%$} & & & & & \\
\hline & Porosity & $36.65 \%$ & & & & & & \\
\hline & GDL thickness (m) & 0.0004 & $+/-0.00001$ & & & & & \\
\hline & Sensor Distance (m) & 0.0265 & & & & & & \\
\hline $\mathbf{N}$ & Trial & $D_{\text {eq }}$ & $\begin{array}{c}\text { Average } \\
\text { Temperature } \\
\left({ }^{\circ} \mathrm{C}\right)\end{array}$ & $\begin{array}{c}\text { Average } \\
\text { Pressure (kPa) }\end{array}$ & $\begin{array}{l}\text { Literature } \\
\text { Value }\end{array}$ & $D_{\text {eff }}$ & $Q$ & $\tau_{\max }$ \\
\hline 1 & Dec20_7 & $1.062 \mathrm{E}-05$ & 22.6 & 95.9 & $2.170 \mathrm{E}-05$ & $3.10 \mathrm{E}-07$ & 0.014 & 0.944 \\
\hline 2 & Dec20_8 & $1.062 \mathrm{E}-05$ & 22.6 & 95.9 & $2.172 \mathrm{E}-05$ & 3.09E-07 & 0.014 & 0.980 \\
\hline 3 & Dec20_9 & 1.059E-05 & 22.6 & 95.9 & $2.172 \mathrm{E}-05$ & $3.08 \mathrm{E}-07$ & 0.014 & 1.117 \\
\hline 4 & Dec20_10 & $1.061 \mathrm{E}-05$ & 22.5 & 95.9 & $2.171 \mathrm{E}-05$ & $3.08 \mathrm{E}-07$ & 0.014 & 1.047 \\
\hline 5 & Dec20_11 & $1.071 \mathrm{E}-05$ & 22.5 & 95.9 & $2.171 \mathrm{E}-05$ & $3.14 \mathrm{E}-07$ & 0.014 & 0.571 \\
\hline 6 & Dec20_12 & $1.062 \mathrm{E}-05$ & 22.5 & 95.9 & $2.170 \mathrm{E}-05$ & $3.09 \mathrm{E}-07$ & 0.014 & 0.976 \\
\hline 7 & Dec20_13 & $1.070 \mathrm{E}-05$ & 22.4 & 96.0 & $2.169 \mathrm{E}-05$ & $3.14 \mathrm{E}-07$ & 0.014 & 0.515 \\
\hline 8 & Dec20_14 & $1.069 \mathrm{E}-05$ & 22.5 & 96.0 & $2.168 \mathrm{E}-05$ & $3.14 \mathrm{E}-07$ & 0.014 & 0.587 \\
\hline 9 & Dec20_15 & $1.078 \mathrm{E}-05$ & 22.5 & 96.0 & $2.169 \mathrm{E}-05$ & $3.19 \mathrm{E}-07$ & 0.015 & 0.172 \\
\hline 10 & Dec20_16 & $1.078 \mathrm{E}-05$ & 22.6 & 96.0 & $2.169 \mathrm{E}-05$ & $3.19 \mathrm{E}-07$ & 0.015 & 0.160 \\
\hline 11 & Jan12_8 & $1.123 \mathrm{E}-05$ & 24.3 & 95.8 & $2.196 \mathrm{E}-05$ & $3.41 \mathrm{E}-07$ & 0.016 & 1.382 \\
\hline 12 & Jan12_9 & 1.115E-05 & 24.2 & 95.8 & 2.195E-05 & 3.37E-07 & 0.015 & 1.029 \\
\hline 13 & Jan12_10 & 1.123E-05 & 24.2 & 95.8 & 2.195E-05 & $3.42 \mathrm{E}-07$ & 0.016 & 1.433 \\
\hline 14 & Jan16_5 & $1.101 \mathrm{E}-05$ & 24.2 & 96.4 & $2.182 \mathrm{E}-05$ & $3.30 \mathrm{E}-07$ & 0.015 & 0.622 \\
\hline 15 & Jan16_6 & 1.119E-05 & 24.4 & 96.4 & $2.185 \mathrm{E}-05$ & $3.41 \mathrm{E}-07$ & 0.016 & 1.480 \\
\hline 16 & Jan16_7 & $1.112 \mathrm{E}-05$ & 24.4 & 96.3 & $2.184 \mathrm{E}-05$ & $3.36 \mathrm{E}-07$ & 0.015 & 1.123 \\
\hline & & & & & Average & $3.22 \mathrm{E}-07$ & 0.015 & \\
\hline & & & & & Std. Dev. & $1.34 \mathrm{E}-08$ & 0.0006 & \\
\hline & & & & & $95 \%$ C.I. & $7.1 \mathrm{E}-09$ & 0.0003 & \\
\hline
\end{tabular}

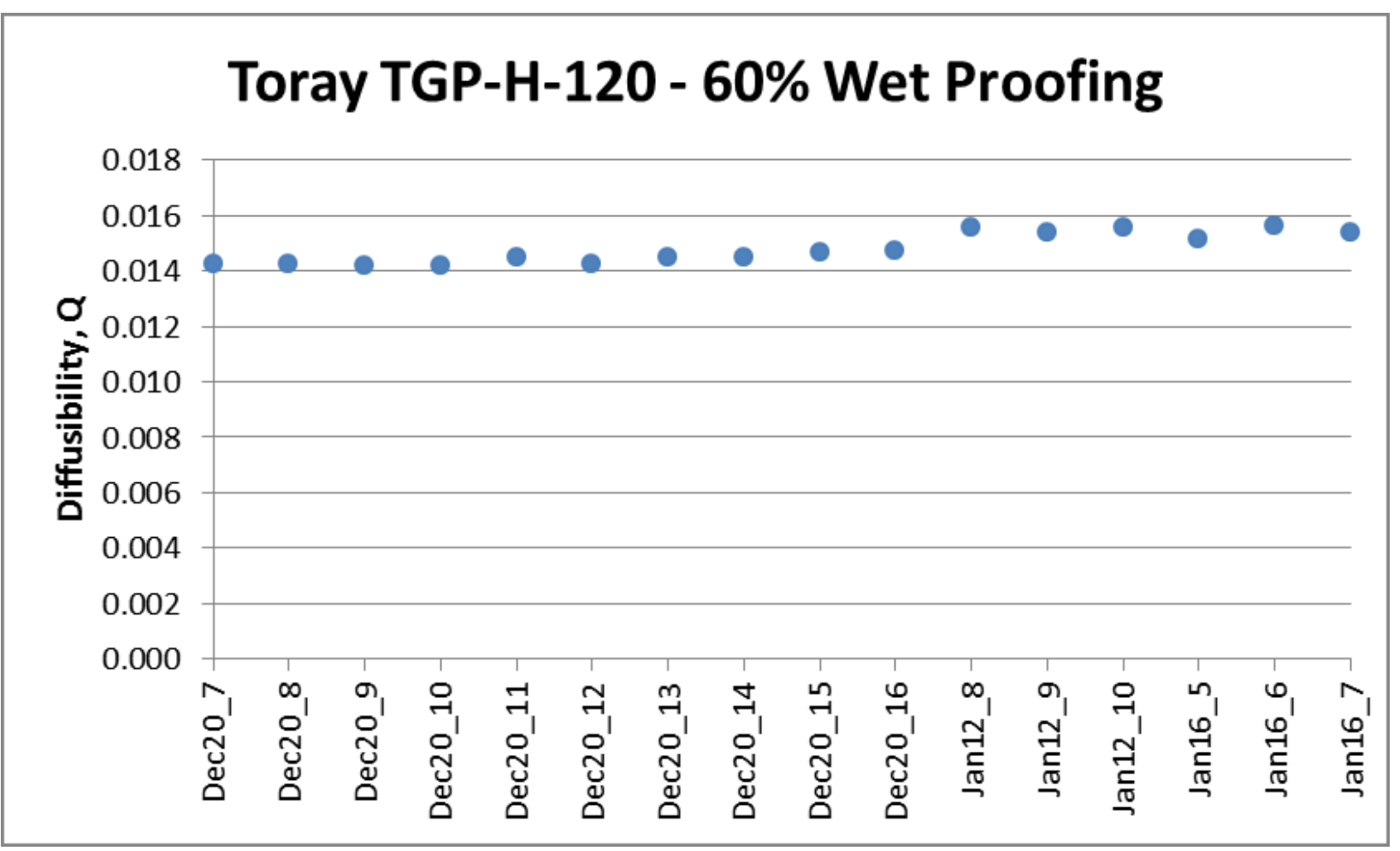




\begin{tabular}{|c|c|c|c|c|c|c|c|c|}
\hline & \multicolumn{2}{|l|}{ Toray TGP-H-060 } & \multirow[b]{2}{*}{$+/-0.6 \%$} & & & & & \\
\hline & Porosity (\%) & $74.83 \%$ & & & & & & \\
\hline & GDL thickness (m) & 0.00022 & $+/-0.00001$ & & & & & \\
\hline & Sensor Distance $(\mathrm{m})$ & 0.0265 & & & & & & \\
\hline $\mathbf{N}$ & Trial & $D_{\text {eq }}$ & \begin{tabular}{|c|} 
Average \\
Temperature \\
$\left({ }^{\circ} \mathrm{C}\right)$ \\
\end{tabular} & $\begin{array}{c}\text { Average } \\
\text { Pressure }(\mathrm{kPa})\end{array}$ & $\begin{array}{l}\text { Literature } \\
\text { Value }\end{array}$ & $D_{\text {eff }}$ & $Q$ & $\tau_{\max }$ \\
\hline 1 & Jan25_11 & $2.14 \mathrm{E}-05$ & 22.9 & 95.9 & 2.175E-05 & $7.88 \mathrm{E}-06$ & 0.36 & 0.594 \\
\hline 2 & Jan25_12 & 2.14E-05 & 22.9 & 95.9 & $2.176 \mathrm{E}-05$ & 7.90E-06 & 0.36 & 0.601 \\
\hline 3 & Jan25_13 & $2.16 \mathrm{E}-05$ & 22.8 & 95.9 & $2.175 \mathrm{E}-05$ & $1.12 \mathrm{E}-05$ & 0.51 & 1.865 \\
\hline 4 & Jan25_14 & $2.14 \mathrm{E}-05$ & 22.7 & 95.9 & $2.175 \mathrm{E}-05$ & $7.56 \mathrm{E}-06$ & 0.35 & 0.473 \\
\hline 5 & Jan25_15 & $2.14 \mathrm{E}-05$ & 22.7 & 95.8 & $2.175 \mathrm{E}-05$ & $7.68 \mathrm{E}-06$ & 0.35 & 0.516 \\
\hline 6 & $\operatorname{Jan} 26 \_6$ & $2.10 \mathrm{E}-05$ & 22.8 & 95.7 & $2.180 \mathrm{E}-05$ & $4.05 \mathrm{E}-06$ & 0.19 & 0.887 \\
\hline 7 & Jan26_7 & $2.14 \mathrm{E}-05$ & 22.9 & 95.7 & $2.180 \mathrm{E}-05$ & $7.10 \mathrm{E}-06$ & 0.33 & 0.287 \\
\hline 8 & Jan26_8 & $2.15 \mathrm{E}-05$ & 22.9 & 95.7 & $2.181 \mathrm{E}-05$ & $7.48 \mathrm{E}-06$ & 0.34 & 0.433 \\
\hline 9 & Jan26_9 & $2.17 \mathrm{E}-05$ & 22.9 & 95.6 & $2.182 \mathrm{E}-05$ & $1.17 \mathrm{E}-05$ & 0.54 & 2.056 \\
\hline 10 & Jan26_10 & 2.17E-05 & 23.0 & 95.6 & $2.184 \mathrm{E}-05$ & $1.10 \mathrm{E}-05$ & 0.50 & 1.770 \\
\hline 11 & Jan27_9 & $2.14 \mathrm{E}-05$ & 23.0 & 95.3 & $2.192 \mathrm{E}-05$ & $5.64 \mathrm{E}-06$ & 0.26 & 0.288 \\
\hline 12 & Jan27_10 & $2.13 \mathrm{E}-05$ & 23.0 & 95.2 & 2.193E-05 & $5.05 \mathrm{E}-06$ & 0.23 & 0.515 \\
\hline 13 & Jan27_11 & $2.13 \mathrm{E}-05$ & 23.0 & 95.1 & $2.194 \mathrm{E}-05$ & $4.53 \mathrm{E}-06$ & 0.21 & 0.715 \\
\hline 14 & Jan28_4 & $2.12 \mathrm{E}-05$ & 23.0 & 95.1 & $2.196 \mathrm{E}-05$ & $3.95 \mathrm{E}-06$ & 0.18 & 0.939 \\
\hline 15 & Jan28_5 & 2.09E-05 & 23.0 & 95.1 & $2.196 \mathrm{E}-05$ & $3.13 \mathrm{E}-06$ & 0.14 & 1.252 \\
\hline 16 & $\operatorname{Jan} 28 \_6$ & $2.11 \mathrm{E}-05$ & 23.0 & 95.1 & $2.196 \mathrm{E}-05$ & $3.91 \mathrm{E}-06$ & 0.18 & 0.954 \\
\hline 17 & Jan28_7 & $2.13 \mathrm{E}-05$ & 22.9 & 95.1 & $2.195 \mathrm{E}-05$ & $4.46 \mathrm{E}-06$ & 0.20 & 0.741 \\
\hline 18 & Jan28_8 & $2.09 \mathrm{E}-05$ & 22.9 & 95.0 & $2.195 \mathrm{E}-05$ & $3.21 \mathrm{E}-06$ & 0.15 & 1.221 \\
\hline 19 & Feb02_5 & $2.13 \mathrm{E}-05$ & 22.4 & 94.6 & $2.198 \mathrm{E}-05$ & $4.71 \mathrm{E}-06$ & 0.21 & 0.651 \\
\hline 20 & Feb02_6 & $2.14 \mathrm{E}-05$ & 22.4 & 94.7 & $2.196 \mathrm{E}-05$ & $5.18 \mathrm{E}-06$ & 0.24 & 0.468 \\
\hline 21 & Feb02_7 & $2.15 \mathrm{E}-05$ & 22.4 & 94.8 & 2.195E-05 & $6.49 \mathrm{E}-06$ & 0.30 & 0.037 \\
\hline & & & & & Average & $6.37 \mathrm{E}-06$ & 0.29 & \\
\hline & & & & & Std. Dev. & $2.58 \mathrm{E}-06$ & 0.119 & \\
\hline & & & & & 95\% C.I. & $1.2 \mathrm{E}-06$ & 0.054 & \\
\hline
\end{tabular}

\section{Toray TGP-H-060}

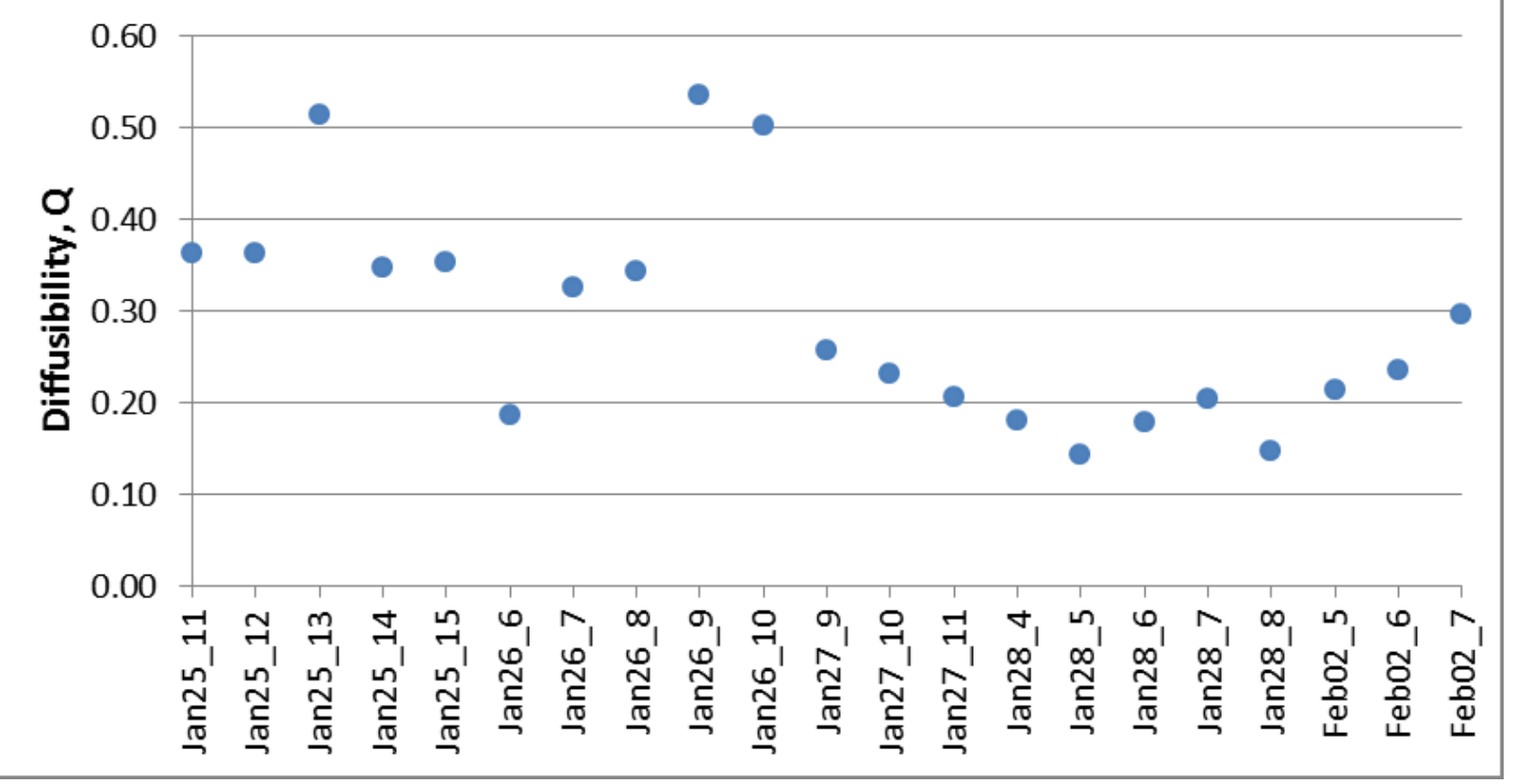




\begin{tabular}{|c|c|c|c|c|c|c|c|c|}
\hline & \multicolumn{2}{|c|}{ Toray TGP-H-060 30\% wet proofing } & \multirow[b]{2}{*}{$+/-1.1 \%$} & & & & & \\
\hline & Porosity (\%) & $64.36 \%$ & & & & & & \\
\hline & GDL thickness (m) & 0.00021 & $+/-0.00001$ & & & & & \\
\hline & Sensor Distance $(\mathrm{m})$ & 0.0265 & & & & & & \\
\hline $\mathbf{N}$ & Trial & $D_{\text {eq }}$ & \begin{tabular}{|c|} 
Average \\
Temperature \\
$\left({ }^{\circ} \mathrm{C}\right)$ \\
\end{tabular} & $\begin{array}{c}\text { Average } \\
\text { Pressure (kPa) }\end{array}$ & $\begin{array}{l}\text { Literature } \\
\text { Value }\end{array}$ & $D_{\text {eff }}$ & Q & $\tau_{\max }$ \\
\hline 1 & Jan26_11 & $2.12 \mathrm{E}-05$ & 23.0 & 95.5 & $2.186 \mathrm{E}-05$ & 4.32E-06 & 0.20 & 0.885 \\
\hline 2 & Jan26_12 & $2.12 \mathrm{E}-05$ & 23.0 & 95.5 & $2.186 \mathrm{E}-05$ & $4.23 \mathrm{E}-06$ & 0.19 & 0.792 \\
\hline 3 & Jan26_13 & $2.14 \mathrm{E}-05$ & 23.0 & 95.5 & 2.187E-05 & $5.70 \mathrm{E}-06$ & 0.26 & 2.310 \\
\hline 4 & Jan27_4 & $2.10 \mathrm{E}-05$ & 23.0 & 95.3 & $2.191 E-05$ & $3.32 \mathrm{E}-06$ & 0.15 & 0.158 \\
\hline 5 & Jan27_5 & $2.12 \mathrm{E}-05$ & 23.1 & 95.3 & $2.192 \mathrm{E}-05$ & 4.07E-06 & 0.19 & 0.622 \\
\hline 6 & Jan27_6 & $2.11 \mathrm{E}-05$ & 23.1 & 95.3 & 2.192E-05 & $3.83 \mathrm{E}-06$ & 0.17 & 0.365 \\
\hline 7 & Jan27_7 & $2.13 \mathrm{E}-05$ & 23.1 & 95.3 & 2.192E-05 & $4.66 \mathrm{E}-06$ & 0.21 & 1.229 \\
\hline 8 & \begin{tabular}{|l|}
$\operatorname{Jan} 27 \_8$ \\
\end{tabular} & $2.12 \mathrm{E}-05$ & 23.1 & 95.3 & 2.192E-05 & $3.95 \mathrm{E}-06$ & 0.18 & 0.490 \\
\hline 9 & Feb01_7 & 1.99E-05 & 22.3 & 96.6 & $2.153 \mathrm{E}-05$ & $1.88 \mathrm{E}-06$ & 0.09 & 1.607 \\
\hline 10 & Feb01_8 & $2.00 \mathrm{E}-05$ & 22.3 & 96.6 & $2.153 \mathrm{E}-05$ & $1.99 \mathrm{E}-06$ & 0.09 & 1.492 \\
\hline 11 & Feb01_9 & $2.02 \mathrm{E}-05$ & 22.3 & 96.6 & $2.153 \mathrm{E}-05$ & $2.28 \mathrm{E}-06$ & 0.11 & 1.190 \\
\hline 12 & Feb01_10 & $2.03 \mathrm{E}-05$ & 22.3 & 96.5 & $2.155 \mathrm{E}-05$ & $2.52 \mathrm{E}-06$ & 0.12 & 0.934 \\
\hline 13 & Feb01_11 & $2.02 \mathrm{E}-05$ & 22.4 & 96.5 & $2.155 \mathrm{E}-05$ & $2.28 \mathrm{E}-06$ & 0.11 & 1.193 \\
\hline 14 & Feb01_12 & $2.05 \mathrm{E}-05$ & 22.4 & 96.5 & $2.156 \mathrm{E}-05$ & $2.78 \mathrm{E}-06$ & 0.13 & 0.668 \\
\hline 15 & Feb01_13 & $2.06 \mathrm{E}-05$ & 22.4 & 96.4 & $2.158 \mathrm{E}-05$ & 3.03E-06 & 0.14 & 0.411 \\
\hline 16 & Feb02_8 & $2.12 \mathrm{E}-05$ & 22.4 & 94.8 & 2.195E-05 & $4.13 \mathrm{E}-06$ & 0.19 & 0.671 \\
\hline 17 & Feb02_9 & $2.12 \mathrm{E}-05$ & 22.4 & 94.8 & $2.195 \mathrm{E}-05$ & $3.93 \mathrm{E}-06$ & 0.18 & 0.466 \\
\hline 18 & Feb02_10 & $2.10 \mathrm{E}-05$ & 22.4 & 94.8 & 2.194E-05 & $3.16 \mathrm{E}-06$ & 0.14 & 0.329 \\
\hline 19 & Feb02_11 & $2.11 \mathrm{E}-05$ & 22.4 & 94.8 & 2.194E-05 & $3.41 \mathrm{E}-06$ & 0.16 & 0.067 \\
\hline 20 & Feb02_12 & $2.11 \mathrm{E}-05$ & 22.4 & 94.9 & 2.193E-05 & $3.69 \mathrm{E}-06$ & 0.17 & 0.219 \\
\hline & & & & & Average & $3.46 \mathrm{E}-06$ & 0.16 & \\
\hline & & & & & Std. Dev. & $9.82 \mathrm{E}-07$ & 0.044 & \\
\hline & & & & & 95\% C.I. & $4.6 \mathrm{E}-07$ & 0.021 & \\
\hline
\end{tabular}

\section{Toray TGP-H-060 - 30\% Wet Proofing}

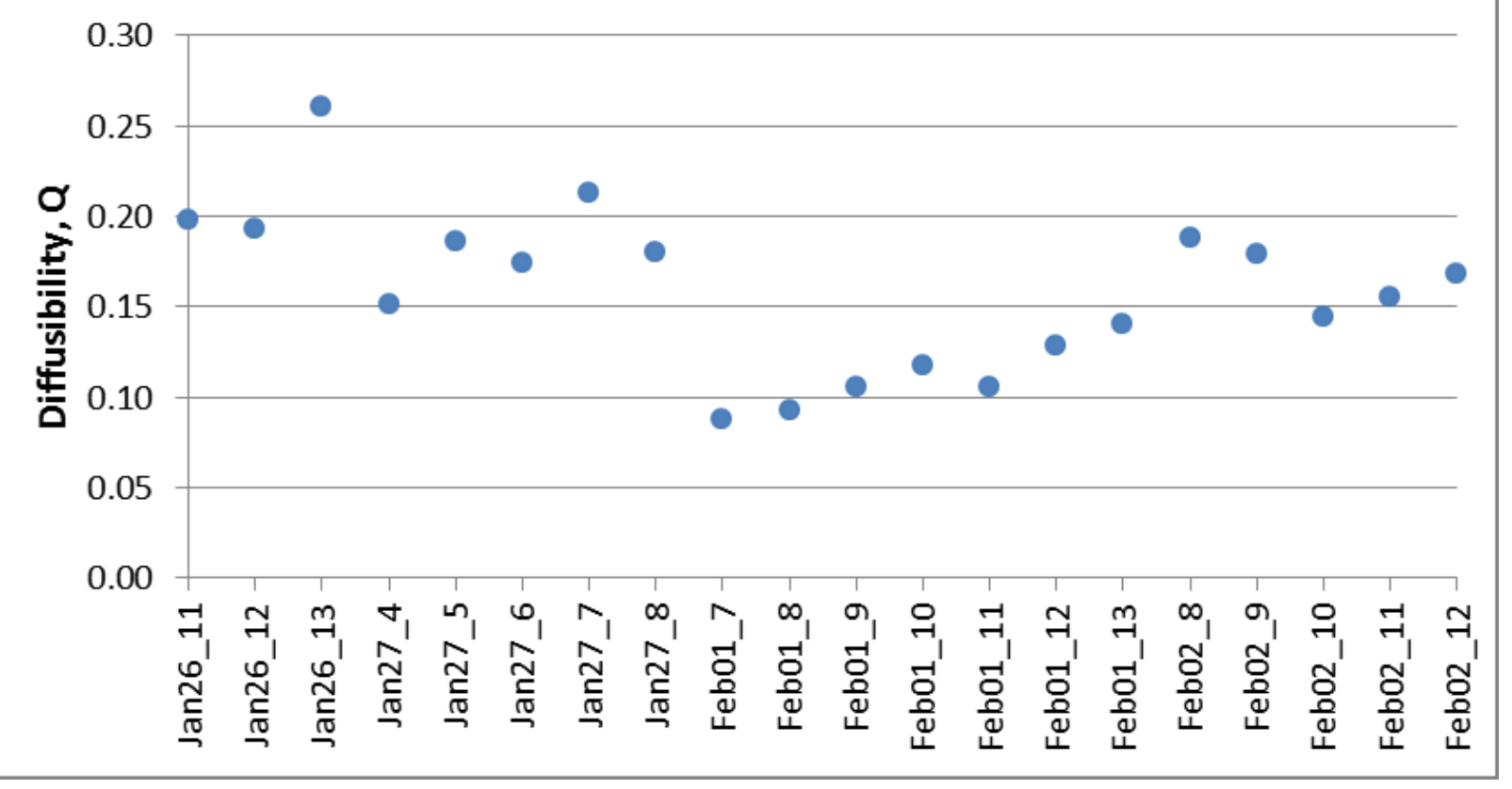




\begin{tabular}{|c|c|c|c|c|c|c|c|c|}
\hline & \multicolumn{2}{|c|}{ Toray TGP-H-060 60\% wet proofing } & \multirow[b]{2}{*}{$+/-1.4 \%$} & & \multirow[t]{2}{*}{ 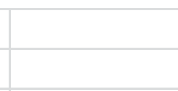 } & \multirow[t]{2}{*}{ 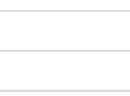 } & & \\
\hline & Porosity (\%) & $46.38 \%$ & & & & & & \\
\hline & GDL thickness (m) & 0.00021 & $+/-0.00001$ & & & & & \\
\hline & Sensor Distance $(\mathrm{m})$ & 0.0265 & & & & & & \\
\hline $\mathbf{N}$ & Trial & $D_{\text {eq }}$ & \begin{tabular}{|c|} 
Average \\
Temperature \\
$\left({ }^{\circ} \mathrm{C}\right)$ \\
\end{tabular} & $\begin{array}{c}\text { Average } \\
\text { Pressure (kPa) }\end{array}$ & $\begin{array}{l}\text { Literature } \\
\text { Value }\end{array}$ & $D_{\text {eff }}$ & Q & $\tau_{\max }$ \\
\hline 1 & Dec15_7 & $1.958 \mathrm{E}-05$ & 22.8 & 95.1 & $2.192 \mathrm{E}-05$ & $1.36 \mathrm{E}-06$ & 0.062 & 0.534 \\
\hline 2 & Dec15_8 & $1.988 \mathrm{E}-05$ & 22.9 & 95.1 & $2.193 \mathrm{E}-05$ & $1.57 \mathrm{E}-06$ & 0.071 & 1.197 \\
\hline 3 & Dec15_9 & $1.991 \mathrm{E}-05$ & 22.9 & 95.2 & $2.192 \mathrm{E}-05$ & $1.59 \mathrm{E}-06$ & 0.073 & 1.288 \\
\hline 4 & Dec15_10 & 1.997E-05 & 22.9 & 95.2 & $2.192 \mathrm{E}-05$ & $1.64 \mathrm{E}-06$ & 0.075 & 1.452 \\
\hline 5 & Dec15_11 & $2.003 \mathrm{E}-05$ & 22.9 & 95.2 & $2.193 \mathrm{E}-05$ & $1.69 \mathrm{E}-06$ & 0.077 & 1.611 \\
\hline 6 & Dec17_4 & 1.897E-05 & 22.6 & 95.4 & $2.183 \mathrm{E}-05$ & $1.09 \mathrm{E}-06$ & 0.050 & 0.326 \\
\hline 7 & Dec17_5 & $1.891 \mathrm{E}-05$ & 22.7 & 95.4 & $2.184 \mathrm{E}-05$ & $1.06 \mathrm{E}-06$ & 0.049 & 0.431 \\
\hline 8 & Dec17_8 & $1.908 \mathrm{E}-05$ & 22.7 & 95.4 & $2.185 \mathrm{E}-05$ & $1.13 \mathrm{E}-06$ & 0.052 & 0.204 \\
\hline 9 & Dec17_9 & $1.928 \mathrm{E}-05$ & 22.8 & 95.4 & $2.185 \mathrm{E}-05$ & $1.22 \mathrm{E}-06$ & 0.056 & 0.099 \\
\hline 10 & Dec17_10 & $1.939 \mathrm{E}-05$ & 22.8 & 95.4 & $2.185 \mathrm{E}-05$ & $1.29 \mathrm{E}-06$ & 0.059 & 0.301 \\
\hline 11 & Jan19_10 & $1.864 \mathrm{E}-05$ & 23.6 & 95.3 & $2.198 \mathrm{E}-05$ & $9.30 \mathrm{E}-07$ & 0.042 & 0.884 \\
\hline 12 & Jan19_11 & $1.859 \mathrm{E}-05$ & 23.5 & 95.3 & $2.196 \mathrm{E}-05$ & $9.19 \mathrm{E}-07$ & 0.042 & 0.916 \\
\hline 13 & Jan19_12 & $1.875 \mathrm{E}-05$ & 23.5 & 95.4 & $2.195 \mathrm{E}-05$ & $9.75 \mathrm{E}-07$ & 0.044 & 0.731 \\
\hline 14 & Jan21_4 & $1.803 \mathrm{E}-05$ & 23.3 & 95.0 & $2.201 \mathrm{E}-05$ & $7.62 \mathrm{E}-07$ & 0.035 & 1.432 \\
\hline 15 & Jan21_5 & $1.823 \mathrm{E}-05$ & 23.3 & 95.0 & $2.201 \mathrm{E}-05$ & $8.11 \mathrm{E}-07$ & 0.037 & 1.272 \\
\hline 16 & Jan21_6 & $1.844 \mathrm{E}-05$ & 23.4 & 95.0 & $2.201 \mathrm{E}-05$ & $8.65 \mathrm{E}-07$ & 0.039 & 1.098 \\
\hline 17 & Jan21_7 & $1.830 \mathrm{E}-05$ & 23.4 & 95.1 & $2.201 \mathrm{E}-05$ & $8.28 \mathrm{E}-07$ & 0.038 & 1.220 \\
\hline 18 & Jan21_8 & 1.837E-05 & 23.4 & 95.1 & $2.201 \mathrm{E}-05$ & $8.46 \mathrm{E}-07$ & 0.038 & 1.161 \\
\hline 19 & $\operatorname{Jan} 22 \_4$ & $1.970 \mathrm{E}-05$ & 24.0 & 95.3 & $2.202 \mathrm{E}-05$ & $1.39 \mathrm{E}-06$ & 0.063 & 0.590 \\
\hline 20 & $\operatorname{Jan} 22 \_5$ & $1.981 \mathrm{E}-05$ & 24.1 & 95.3 & $2.205 \mathrm{E}-05$ & $1.45 \mathrm{E}-06$ & 0.066 & 0.778 \\
\hline 21 & $\operatorname{Jan} 22 \_6$ & $1.988 \mathrm{E}-05$ & 24.3 & 95.3 & $2.208 \mathrm{E}-05$ & $1.48 \mathrm{E}-06$ & 0.067 & 0.875 \\
\hline 22 & $\operatorname{Jan} 22 \_7$ & $1.992 \mathrm{E}-05$ & 24.3 & 95.2 & \begin{tabular}{|r|}
$2.209 \mathrm{E}-05$ \\
\end{tabular} & $1.50 \mathrm{E}-06$ & 0.068 & 0.948 \\
\hline & & & & & Average & $1.20 \mathrm{E}-06$ & 0.055 & \\
\hline & & & & & Std. Dev. & 3.07E-07 & 0.0140 & \\
\hline & & & & & 95\% C.I. & $1.4 \mathrm{E}-07$ & 0.0062 & \\
\hline
\end{tabular}

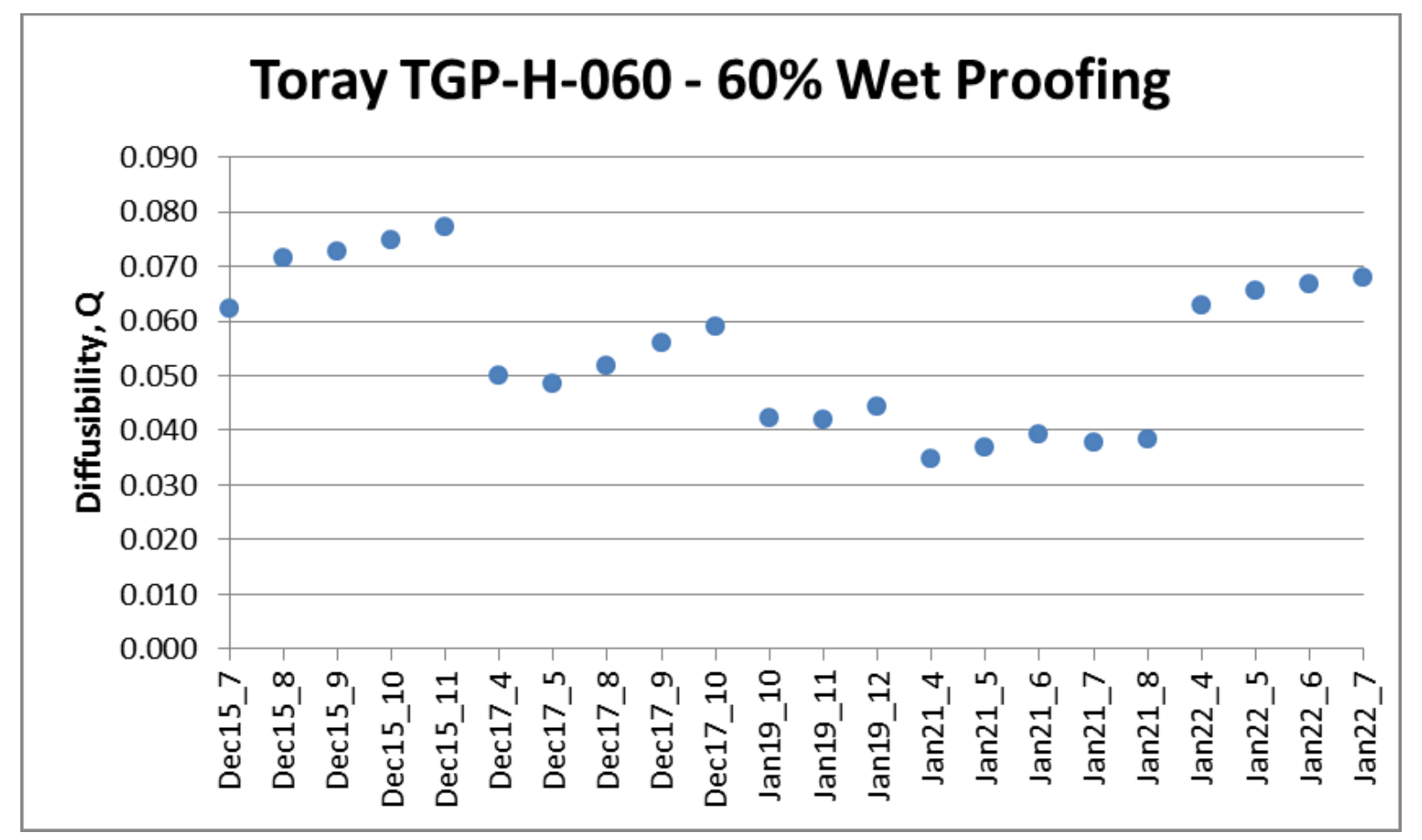




\begin{tabular}{|c|c|c|c|c|c|c|c|c|}
\hline & \multicolumn{2}{|c|}{ SolviCore Type A 5\% PTFE } & \multirow[b]{2}{*}{$+/-0.2 \%$} & & & & & \\
\hline & Porosity (\%) & $81.93 \%$ & & & & & & \\
\hline & GDL thickness (m) & 0.00021 & $+/-0.00001$ & & & & & \\
\hline & Sensor Distance $(\mathrm{m})$ & 0.0273 & & & & & & \\
\hline $\mathbf{N}$ & Trial & $\mathrm{D}_{\mathrm{eq}}$ & $\begin{array}{c}\text { Average } \\
\text { Temperature } \\
\left({ }^{\circ} \mathrm{C}\right) \\
\end{array}$ & $\begin{array}{c}\text { Average } \\
\text { Pressure (kPa) }\end{array}$ & $\begin{array}{l}\text { Literature } \\
\text { Value }\end{array}$ & $D_{\text {eff }}$ & $Q$ & $\tau_{\max }$ \\
\hline 1 & May12_4 & $2.08 \mathrm{E}-05$ & 23.0 & 95.9 & $2.178 \mathrm{E}-05$ & $3.01 \mathrm{E}-06$ & 0.14 & 1.283 \\
\hline 2 & May12_5 & 2.09E-05 & 23.2 & 95.9 & $2.179 \mathrm{E}-05$ & $3.45 \mathrm{E}-06$ & 0.16 & 1.151 \\
\hline 3 & May12_6 & $2.12 \mathrm{E}-05$ & 23.3 & 95.9 & $2.180 \mathrm{E}-05$ & 4.44E-06 & 0.20 & 0.854 \\
\hline 4 & May12_7 & $2.13 \mathrm{E}-05$ & 23.2 & 95.9 & $2.181 \mathrm{E}-05$ & $5.60 \mathrm{E}-06$ & 0.26 & 0.506 \\
\hline 5 & May12_8 & $2.13 \mathrm{E}-05$ & 23.2 & 95.9 & $2.180 \mathrm{E}-05$ & $5.51 \mathrm{E}-06$ & 0.25 & 0.533 \\
\hline 6 & May13_5 & $2.18 \mathrm{E}-05$ & 23.2 & 95.1 & $2.198 \mathrm{E}-05$ & $9.84 \mathrm{E}-06$ & 0.45 & 0.745 \\
\hline 7 & Aayy13_6 & $2.20 E-05$ & 23.1 & 95.1 & Z.198E-05 & $3.65 E-05$ & 465 & 8.694 \\
\hline 8 & May13_7 & $2.18 \mathrm{E}-05$ & 23.1 & 95.1 & $2.197 \mathrm{E}-05$ & $1.23 \mathrm{E}-05$ & 0.56 & 1.488 \\
\hline 9 & Aayy13_8 & $Z .19 E-05$ & 23.1 & 95.0 & $z .198 E-05$ & 1.58E-05 & 0.72 & 2.528 \\
\hline 10 & May13_9 & $2.17 \mathrm{E}-05$ & 23.0 & 95.0 & $2.198 \mathrm{E}-05$ & $9.00 \mathrm{E}-06$ & 0.41 & 0.494 \\
\hline 11 & Aayy13_10 & Z.21E 05 & 23.0 & 95.0 & Z.198E 05 & 1.29E 04 & 5.85 & 36.129 \\
\hline 12 & May14_4 & $2.14 \mathrm{E}-05$ & 22.7 & 94.8 & $2.198 \mathrm{E}-05$ & $4.96 \mathrm{E}-06$ & 0.23 & 0.712 \\
\hline 13 & May14_5 & $2.18 \mathrm{E}-05$ & 22.8 & 94.8 & 2.199E-05 & $9.45 \mathrm{E}-06$ & 0.43 & 0.625 \\
\hline 14 & May14_6 & $2.18 \mathrm{E}-05$ & 22.9 & 94.8 & $2.200 \mathrm{E}-05$ & $9.72 \mathrm{E}-06$ & 0.44 & 0.706 \\
\hline 15 & May14_7 & $2.18 \mathrm{E}-05$ & 22.9 & 94.8 & $2.201 \mathrm{E}-05$ & $1.13 \mathrm{E}-05$ & 0.51 & 1.172 \\
\hline 16 & May14_8 & $2.17 \mathrm{E}-05$ & 22.9 & 94.8 & $2.201 \mathrm{E}-05$ & $8.08 \mathrm{E}-06$ & 0.37 & 0.214 \\
\hline 17 & May15_4 & $2.12 \mathrm{E}-05$ & 22.5 & 95.1 & $2.189 \mathrm{E}-05$ & $4.10 \mathrm{E}-06$ & 0.19 & 0.963 \\
\hline 18 & May15_5 & $2.10 \mathrm{E}-05$ & 22.5 & 95.1 & $2.190 \mathrm{E}-05$ & $3.20 \mathrm{E}-06$ & 0.15 & 1.230 \\
\hline 19 & May15_6 & $2.13 \mathrm{E}-05$ & 22.5 & 95.1 & $2.190 \mathrm{E}-05$ & $4.71 \mathrm{E}-06$ & 0.22 & 0.780 \\
\hline 20 & May15_7 & 2.17E-05 & 22.6 & 95.1 & $2.191 \mathrm{E}-05$ & $9.81 \mathrm{E}-06$ & 0.45 & 0.742 \\
\hline 21 & May15_8 & $2.18 \mathrm{E}-05$ & 22.6 & 95.1 & \begin{tabular}{|l|}
$2.191 \mathrm{E}-05$ \\
\end{tabular} & $1.34 \mathrm{E}-05$ & 0.61 & 1.826 \\
\hline & & & & & Average & $7.33 \mathrm{E}-06$ & 0.33 & \\
\hline & & & & & Std. Dev. & $3.36 \mathrm{E}-06$ & 0.153 & \\
\hline & & & & & 95\% C.I. & $1.5 \mathrm{E}-06$ & 0.068 & \\
\hline
\end{tabular}

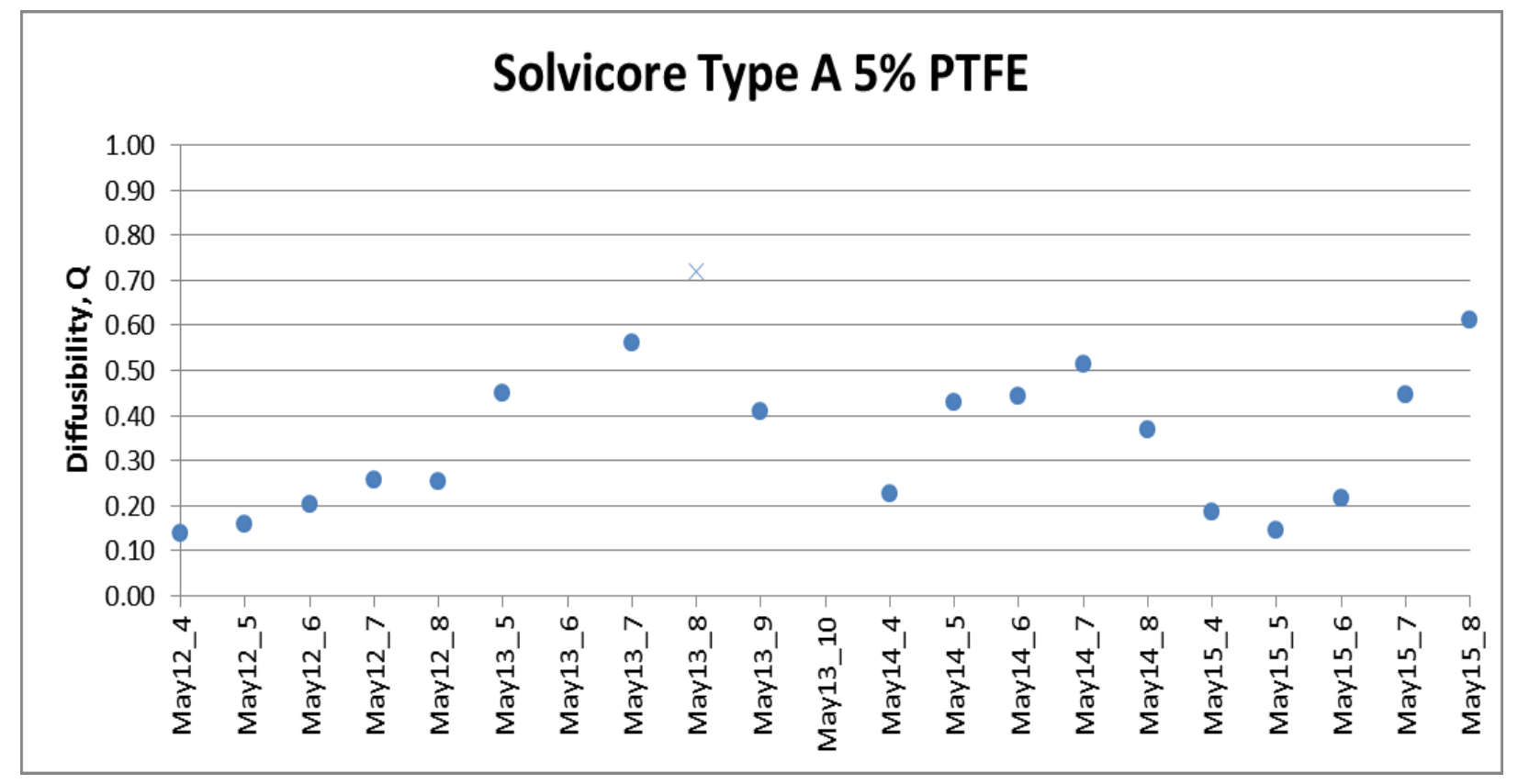




\begin{tabular}{|c|c|c|c|c|c|c|c|c|c|c|c|c|c|c|}
\hline & \multicolumn{2}{|l|}{ SolviCore Type A MPL } & \multirow[b]{2}{*}{$+/-0.9 \%$} & & & & & & \multirow[b]{2}{*}{$T_{\text {avg }}$} & \multirow[b]{2}{*}{$\mathbf{P}_{\text {avg }}$} & & & & \\
\hline & Porosity (\%) & $75.01 \%$ & & & & & & & & & & & & \\
\hline & GDL thickness (m) & 0.00025 & $+/-0.00001$ & & & & & & 22.4 & 95.7 & & & & \\
\hline & Sensor Distance (m) & 0.0273 & & & & & & & & & & & & \\
\hline N & Trial & $D_{\text {eq }}$ & $\begin{array}{c}\text { Average } \\
\text { Temperature } \\
\left({ }^{\circ} \mathrm{C}\right) \\
\end{array}$ & $\begin{array}{c}\text { Average } \\
\text { Pressure (kPa) }\end{array}$ & $\begin{array}{l}\text { Literature } \\
\text { Value }\end{array}$ & $D_{\text {eff }}$ & $\mathrm{Q}$ & $\tau_{\max }$ & $t, M P L$ & Deff,MPL & Deff,bulk & & & \\
\hline 1 & Mar19_6 & $2.00 E-05$ & 22.4 & 97.3 & $2.137 \mathrm{E}-05$ & 2.44E-06 & 0.11 & 1.109 & $6.640 \mathrm{E}-05$ & $1.01 \mathrm{E}-06$ & 4.082E-06 & & & \\
\hline 2 & Mar19_7 & $2.03 E-05$ & 22.4 & 97.4 & $2.137 \mathrm{E}-05$ & $3.03 E-06$ & 0.14 & 0.035 & & $1.45 \mathrm{E}-06$ & 4.082E-06 & & & \\
\hline 3 & Mar19_8 & $2.06 \mathrm{E}-05$ & 22.5 & 97.4 & $2.137 \mathrm{E}-05$ & 4.05E-06 & 0.19 & 2.010 & Deff,substrate & 2.65E-06 & $4.082 \mathrm{E}-06$ & & & \\
\hline 4 & Mar19_9 & $2.04 \mathrm{E}-05$ & 22.5 & 97.4 & 2.137E-05 & 3.53E-06 & 0.17 & 1.015 & \begin{tabular}{|l|}
$7.33 E-06$ \\
\end{tabular} & 1.95E-06 & $4.082 \mathrm{E}-06$ & & & \\
\hline 5 & Aar19_10 & Z.08E-05 & 22.5 & 97.4 & Z.138E-05 & 4.99E 06 & 0.23 & 3.848 & & & & & & \\
\hline 6 & Mar29_6 & $2.05 E-05$ & 22.5 & 96.5 & $2.156 \mathrm{E}-05$ & $3.31 \mathrm{E}-06$ & 0.15 & 0.515 & MPL Porosity & $1.70 \mathrm{E}-06$ & $4.118 \mathrm{E}-06$ & & & \\
\hline 7 & Mar29_7 & $2.03 E-05$ & 22.5 & 96.6 & $2.156 \mathrm{E}-05$ & $2.82 \mathrm{E}-06$ & 0.13 & 0.423 & \begin{tabular}{|l|}
$6.39 \mathrm{E}-01$ \\
\end{tabular} & $1.28 \mathrm{E}-06$ & 4.119E-06 & & & \\
\hline 8 & Mar29_8 & $2.02 \mathrm{E}-05$ & 22.6 & 96.5 & $2.157 \mathrm{E}-05$ & $2.61 \mathrm{E}-06$ & 0.12 & 0.825 & & $1.13 \mathrm{E}-06$ & 4.121E-06 & & & \\
\hline 9 & Mar29_9 & $2.05 E-05$ & 22.6 & 96.5 & $2.158 \mathrm{E}-05$ & $3.08 \mathrm{E}-06$ & 0.14 & 0.076 & & $1.49 \mathrm{E}-06$ & 4.122E-06 & & & \\
\hline 10 & Mar29_10 & 2.07E-05 & 22.6 & 96.5 & $2.158 \mathrm{E}-05$ & $3.70 \mathrm{E}-06$ & 0.17 & 1.277 & & $2.15 \mathrm{E}-06$ & 4.123E-06 & & & \\
\hline 11 & Mar30_10 & $2.05 E-05$ & 22.6 & 95.8 & $2.176 \mathrm{E}-05$ & $2.83 E-06$ & 0.13 & 0.447 & & $1.28 \mathrm{E}-06$ & $4.156 \mathrm{E}-06$ & & & \\
\hline 12 & Mar30_11 & $2.08 \mathrm{E}-05$ & 22.7 & 95.7 & 2.177E-05 & $3.63 \mathrm{E}-06$ & 0.17 & 1.074 & & $2.05 \mathrm{E}-06$ & 4.159E-06 & & & \\
\hline 13 & Apr16_4 & $2.03 \mathrm{E}-05$ & 22.4 & 94.6 & 2.200E-05 & 2.19E-06 & 0.10 & 1.726 & & $8.54 \mathrm{E}-07$ & $4.202 \mathrm{E}-06$ & & & \\
\hline 14 & Apr16_5 & 2.06E-05 & 22.5 & 94.6 & $2.201 \mathrm{E}-05$ & 2.55E-06 & 0.12 & 1.042 & & $1.08 \mathrm{E}-06$ & 4.204E-06 & & & \\
\hline 15 & Apr16_6 & $2.07 E-05$ & 22.5 & 94.5 & $2.203 \mathrm{E}-05$ & 2.69E-06 & 0.12 & 0.792 & & $1.17 \mathrm{E}-06$ & 4.207E-06 & & Deff/Deff & \\
\hline 16 & Apr16_7 & $2.06 \mathrm{E}-05$ & 22.5 & 94.4 & $2.205 \mathrm{E}-05$ & $2.55 \mathrm{E}-06$ & 0.12 & 1.049 & & $1.08 \mathrm{E}-06$ & $4.212 \mathrm{E}-06$ & & ,substrate & DKn/Deff \\
\hline 17 & Apr16_8 & $2.08 \mathrm{E}-05$ & 22.5 & 94.4 & $2.206 \mathrm{E}-05$ & $2.96 \mathrm{E}-06$ & 0.13 & 0.288 & & $1.38 \mathrm{E}-06$ & $4.213 \mathrm{E}-06$ & & $41.86 \%$ & $79.89 \%$ \\
\hline 18 & Apr17_5 & $2.08 \mathrm{E}-05$ & 22.1 & 94.2 & 2.204E-05 & 2.90E-06 & 0.13 & 0.398 & & $1.33 \mathrm{E}-06$ & $4.210 \mathrm{E}-06$ & & & \\
\hline 19 & Apr17_6 & $2.10 \mathrm{E}-05$ & 22.1 & 94.2 & $2.205 E-05$ & $3.46 \mathrm{E}-06$ & 0.16 & 0.664 & & $1.85 \mathrm{E}-06$ & $4.211 \mathrm{E}-06$ & & & \\
\hline 20 & Apr17_7 & $2.10 \mathrm{E}-05$ & 22.2 & 94.2 & $2.205 \mathrm{E}-05$ & $3.32 \mathrm{E}-06$ & 0.15 & 0.404 & & $1.71 \mathrm{E}-06$ & $4.213 \mathrm{E}-06$ & & & \\
\hline 21 & Apr17_8 & $2.12 \mathrm{E}-05$ & 22.2 & 94.2 & $2.206 \mathrm{E}-05$ & 4.04E-06 & 0.18 & 1.760 & & $2.61 \mathrm{E}-06$ & $4.214 \mathrm{E}-06$ & & & \\
\hline 22 & Apr17_9 & $2.11 \mathrm{E}-05$ & 22.3 & 94.2 & $2.208 \mathrm{E}-05$ & $3.54 \mathrm{E}-06$ & 0.16 & 0.810 & & $1.94 \mathrm{E}-06$ & $4.218 \mathrm{E}-06$ & Deff,MPL/ & & \\
\hline 23 & Apr18_5 & $2.04 \mathrm{E}-05$ & 22.2 & 95.6 & 2.174E-05 & 2.63E-06 & 0.12 & 0.837 & & $1.13 \mathrm{E}-06$ & 4.153E-06 & Deff,substr & & \\
\hline 24 & Apr18_6 & $2.04 \mathrm{E}-05$ & 22.2 & 95.6 & $2.174 \mathrm{E}-05$ & $2.70 \mathrm{E}-06$ & 0.12 & 0.703 & & $1.18 \mathrm{E}-06$ & $4.153 \mathrm{E}-06$ & ate & DKn & dpore \\
\hline & & & & & Average & 3.07E-06 & 0.14 & & Average & $1.54 \mathrm{E}-06$ & $4.16 \mathrm{E}-06$ & $21.04 \%$ & $2.45 \mathrm{E}-06$ & $1.66 \mathrm{E}-08$ \\
\hline & & & & & Std. Dev. & 5.17E-07 & 0.024 & & stdev & 4.99E-07 & $5.12 \mathrm{E}-08$ & & & \\
\hline & & & & & $95 \%$ C.I. & $2.2 \mathrm{E}-07$ & 0.010 & & \begin{tabular}{|l|l}
$95 \%$ C.I. \\
\end{tabular} & $2.16 \mathrm{E}-07$ & $2.22 \mathrm{E}-08$ & & & \\
\hline & & & & & & & & & \begin{tabular}{|r|} 
upper \\
\end{tabular} & $1.76 \mathrm{E}-06$ & $4.18 \mathrm{E}-06$ & & & \\
\hline & & & & & & & & & lower & $1.33 \mathrm{E}-06$ & 4.14E-06 & & & \\
\hline
\end{tabular}




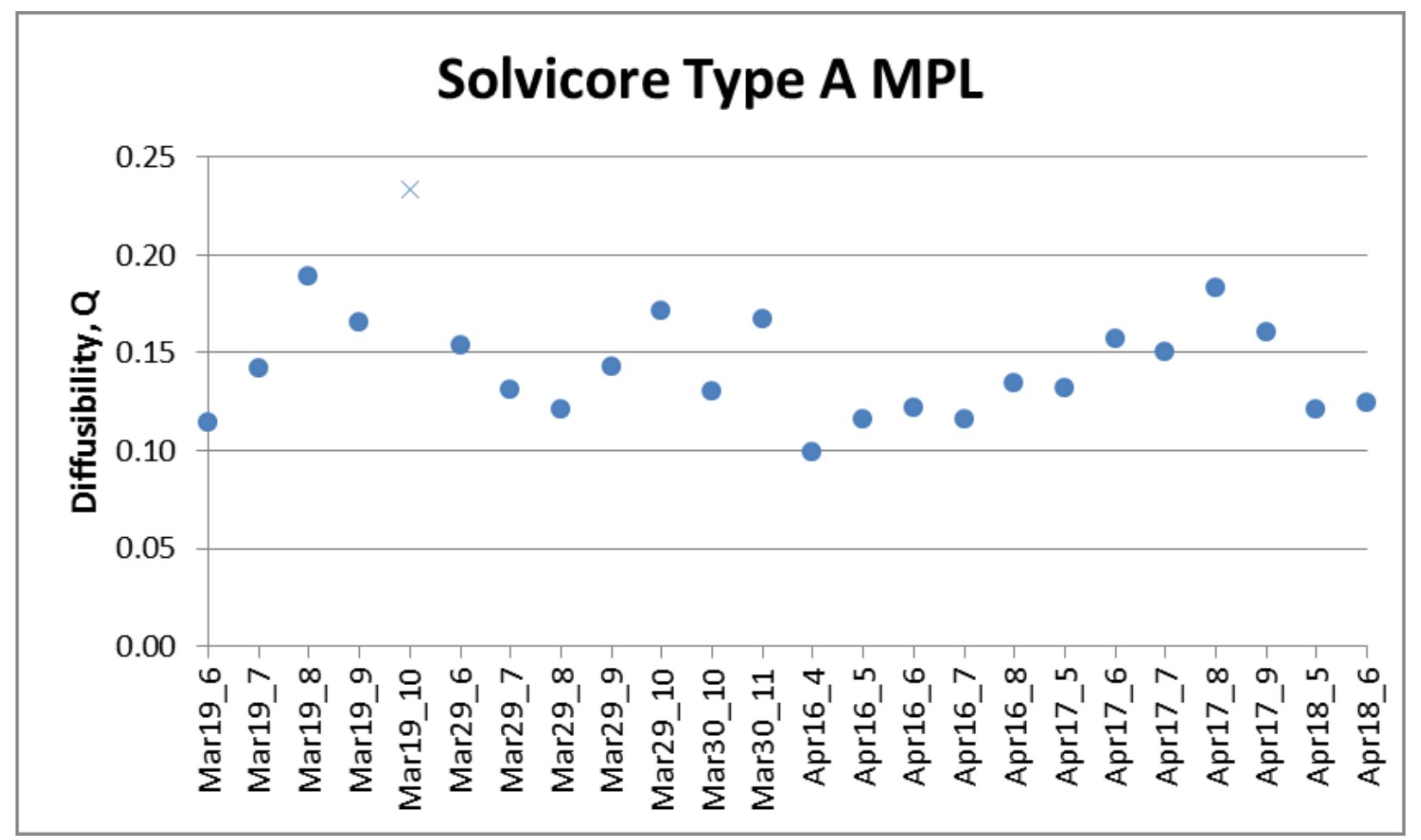




\begin{tabular}{|c|c|c|c|c|c|c|c|c|}
\hline & \multicolumn{2}{|l|}{ Solvicore Type B MPL } & \multirow[b]{2}{*}{$+/-1.2 \%$} & & & & & \\
\hline & Porosity (\%) & $76.53 \%$ & & & & & & \\
\hline & GDL thickness (m) & 0.00023 & $+/-0.00001$ & & & & & \\
\hline & Sensor Distance $(\mathrm{m})$ & 0.0273 & & & & & & \\
\hline $\mathbf{N}$ & Trial & $D_{\text {eq }}$ & \begin{tabular}{|c|} 
Average \\
Temperature \\
$\left({ }^{\circ} \mathrm{C}\right)$ \\
\end{tabular} & $\begin{array}{c}\text { Average } \\
\text { Pressure (kPa) }\end{array}$ & $\begin{array}{l}\text { Literature } \\
\text { Value }\end{array}$ & $D_{\text {eff }}$ & $Q$ & $\tau_{\max }$ \\
\hline 1 & Mar27_4 & $2.05 E-05$ & 22.8 & 96.3 & $2.164 \mathrm{E}-05$ & $2.90 \mathrm{E}-06$ & 0.13 & 0.606 \\
\hline 2 & Mar27_5 & $2.08 \mathrm{E}-05$ & 22.8 & 96.3 & $2.166 \mathrm{E}-05$ & $3.72 \mathrm{E}-06$ & 0.17 & 0.545 \\
\hline 3 & Mar27_6 & $2.07 \mathrm{E}-05$ & 22.9 & 96.3 & 2.167E-05 & $3.29 \mathrm{E}-06$ & 0.15 & 0.061 \\
\hline 4 & Mar27 7 & Z.11E 05 & 22.9 & 96.3 & $2.167 E 05$ & 5.30E 06 & 0.24 & 2.759 \\
\hline 5 & Mar27_8 & $2.07 \mathrm{E}-05$ & 22.8 & 96.3 & $2.166 \mathrm{E}-05$ & $3.40 \mathrm{E}-06$ & 0.16 & 0.087 \\
\hline 6 & May17_4 & $2.10 \mathrm{E}-05$ & 22.6 & 95.8 & $2.175 E-05$ & $4.32 \mathrm{E}-06$ & 0.20 & 1.366 \\
\hline 7 & Aay 17_5 & $Z .13 E-05$ & 22.7 & 95.8 & Z.176E-05 & $6.48 E-06$ & 0.30 & 4.386 \\
\hline 8 & May17_6 & $2.12 \mathrm{E}-05$ & 22.8 & 95.8 & 2.177E-05 & $4.84 \mathrm{E}-06$ & 0.22 & 2.088 \\
\hline 9 & May17_7 & $2.08 \mathrm{E}-05$ & 23.0 & 95.8 & $2.179 \mathrm{E}-05$ & $3.21 \mathrm{E}-06$ & 0.15 & 0.201 \\
\hline 10 & May17_8 & $2.07 \mathrm{E}-05$ & 23.1 & 95.8 & $2.181 E-05$ & $3.07 \mathrm{E}-06$ & 0.14 & 0.399 \\
\hline 11 & May18_4 & $2.05 \mathrm{E}-05$ & 22.7 & 95.7 & $2.178 \mathrm{E}-05$ & $2.54 \mathrm{E}-06$ & 0.12 & 1.134 \\
\hline 12 & May18_5 & $2.06 \mathrm{E}-05$ & 22.7 & 95.6 & $2.180 \mathrm{E}-05$ & $2.72 \mathrm{E}-06$ & 0.12 & 0.894 \\
\hline 13 & May18_6 & $2.07 \mathrm{E}-05$ & 22.8 & 95.6 & $2.181 \mathrm{E}-05$ & $2.91 \mathrm{E}-06$ & 0.13 & 0.626 \\
\hline 14 & May18_7 & $2.09 \mathrm{E}-05$ & 22.9 & 95.7 & $2.181 \mathrm{E}-05$ & $3.53 \mathrm{E}-06$ & 0.16 & 0.239 \\
\hline 15 & May18_8 & $2.11 \mathrm{E}-05$ & 23.0 & 95.7 & $2.182 \mathrm{E}-05$ & $4.56 \mathrm{E}-06$ & 0.21 & 1.682 \\
\hline 16 & May19_4 & $2.03 \mathrm{E}-05$ & 22.7 & 95.8 & $2.175 E-05$ & $2.28 \mathrm{E}-06$ & 0.10 & 1.497 \\
\hline 17 & May19_5 & $2.06 \mathrm{E}-05$ & 22.8 & 95.9 & $2.175 \mathrm{E}-05$ & $2.97 \mathrm{E}-06$ & 0.14 & 0.538 \\
\hline 18 & May19_6 & $2.08 \mathrm{E}-05$ & 22.8 & 95.9 & 2.174E-05 & $3.31 \mathrm{E}-06$ & 0.15 & 0.051 \\
\hline & & & & & Average & $3.35 \mathrm{E}-06$ & 0.15 & \\
\hline & & & & & Std. Dev. & $7.14 \mathrm{E}-07$ & 0.033 & \\
\hline & & & & & 95\% C.I. & $3.8 \mathrm{E}-07$ & 0.017 & \\
\hline
\end{tabular}

\section{Solvicore Type B MPL}

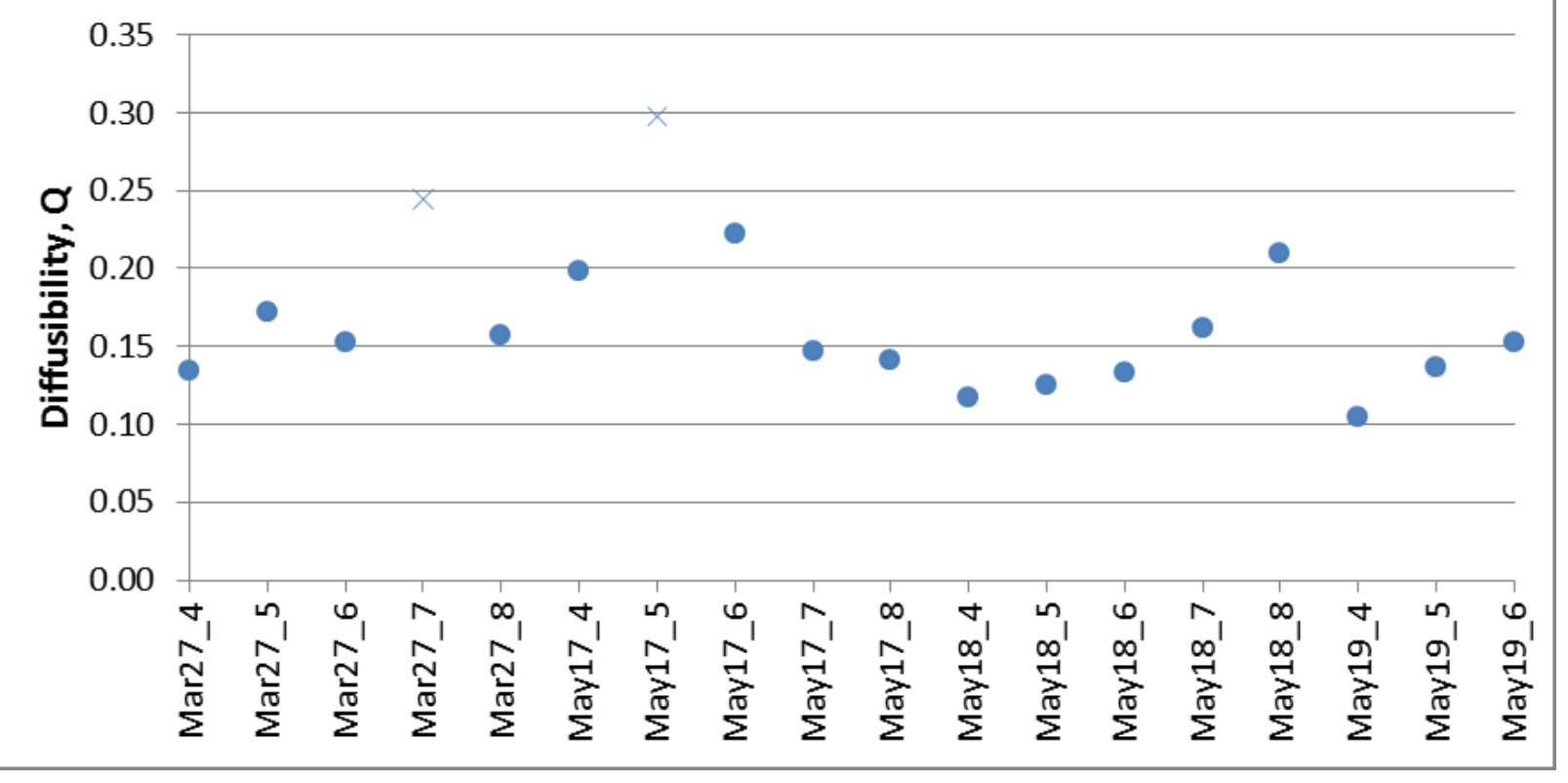




\begin{tabular}{|c|c|c|c|c|c|c|c|c|}
\hline & \multicolumn{2}{|l|}{ SGL 10 AA } & \multirow[b]{2}{*}{$+/-0.3 \%$} & & & & & \\
\hline & \begin{tabular}{|l|} 
Porosity (\%) \\
\end{tabular} & $84.19 \%$ & & & & & & \\
\hline & GDL thickness (m) & 0.0004 & $+/-0.00001$ & & & & & \\
\hline & Sensor Distance $(\mathrm{m})$ & 0.0273 & & & & & & \\
\hline $\mathbf{N}$ & Trial & $D_{\text {eq }}$ & $\begin{array}{c}\text { Average } \\
\text { Temperature } \\
\left({ }^{\circ} \mathrm{C}\right) \\
\end{array}$ & $\begin{array}{c}\text { Average } \\
\text { Pressure (kPa) }\end{array}$ & $\begin{array}{l}\text { Literature } \\
\text { Value }\end{array}$ & $D_{\text {eff }}$ & Q & $\tau_{\max }$ \\
\hline 1 & Apr19_4 & 2.07E-05 & 22.2 & 96.0 & $2.164 \mathrm{E}-05$ & 5.30E-06 & 0.24 & 1.110 \\
\hline 2 & Apr19_5 & $2.06 \mathrm{E}-05$ & 22.2 & 96.0 & $2.164 \mathrm{E}-05$ & $5.04 \mathrm{E}-06$ & 0.23 & 1.201 \\
\hline 3 & Apr19_6 & $2.13 \mathrm{E}-05$ & 22.3 & 96.0 & $2.165 \mathrm{E}-05$ & $1.02 \mathrm{E}-05$ & 0.47 & 0.584 \\
\hline 4 & Apr19_7 & $2.14 \mathrm{E}-05$ & 22.3 & 96.0 & $2.165 \mathrm{E}-05$ & $1.12 \mathrm{E}-05$ & 0.52 & 0.944 \\
\hline 5 & Apr19_8 & $2.14 \mathrm{E}-05$ & 22.3 & 96.1 & $2.165 \mathrm{E}-05$ & $1.24 \mathrm{E}-05$ & 0.57 & 1.358 \\
\hline 6 & Apr20_4 & $2.15 \mathrm{E}-05$ & 22.2 & 94.4 & $2.200 \mathrm{E}-05$ & 8.07E-06 & 0.37 & 0.197 \\
\hline 7 & Apr20_5 & $2.18 \mathrm{E}-05$ & 22.3 & 94.5 & $2.201 \mathrm{E}-05$ & $1.23 \mathrm{E}-05$ & 0.56 & 1.234 \\
\hline 8 & Apr20_6 & $2.18 \mathrm{E}-05$ & 22.3 & 94.6 & $2.199 \mathrm{E}-05$ & $1.45 \mathrm{E}-05$ & 0.66 & 2.005 \\
\hline 9 & Apr20_7 & $2.23 E-05$ & 22.3 & 94.6 & Z.197E 05 & 5.17E 04 & 23.54 & 173.318 \\
\hline 10 & Aprzo_8 & $2.22 E 05$ & 22.3 & 94.7 & Z.197E 05 & 1.05E 04 & 4.76 & 32.712 \\
\hline 11 & Apr22_4 & $2.07 \mathrm{E}-05$ & 22.1 & 96.8 & $2.146 \mathrm{E}-05$ & $5.96 \mathrm{E}-06$ & 0.28 & 0.864 \\
\hline 12 & Apr22_5 & $2.11 \mathrm{E}-05$ & 22.2 & 96.8 & 2.147E-05 & $1.02 \mathrm{E}-05$ & 0.48 & 0.624 \\
\hline 13 & Apr22_6 & $2.11 \mathrm{E}-05$ & 22.2 & 96.8 & $2.148 \mathrm{E}-05$ & 9.07E-06 & 0.42 & 0.220 \\
\hline 14 & Apr22_7 & $2.10 \mathrm{E}-05$ & 22.3 & 96.7 & 2.149E-05 & $8.49 \mathrm{E}-06$ & 0.39 & 0.014 \\
\hline 15 & Apr22_8 & $2.13 \mathrm{E}-05$ & 22.4 & 96.7 & $2.151 \mathrm{E}-05$ & 1.37E-05 & 0.64 & 1.839 \\
\hline 16 & Apr23_4 & $2.11 \mathrm{E}-05$ & 22.6 & 94.9 & $2.196 \mathrm{E}-05$ & $5.81 \mathrm{E}-06$ & 0.26 & 0.961 \\
\hline 17 & Apr23_5 & $2.11 \mathrm{E}-05$ & 22.6 & 95.0 & $2.193 \mathrm{E}-05$ & $6.05 \mathrm{E}-06$ & 0.28 & 0.879 \\
\hline 18 & Apr23_6 & $2.13 \mathrm{E}-05$ & 22.6 & 95.0 & $2.191 \mathrm{E}-05$ & 7.41E-06 & 0.34 & 0.411 \\
\hline 19 & Apr23_7 & $2.17 \mathrm{E}-05$ & 22.6 & 95.0 & 2.191E-05 & $1.28 \mathrm{E}-05$ & 0.59 & 1.445 \\
\hline 20 & Apr23_8 & $2.14 \mathrm{E}-05$ & 22.5 & 95.1 & $2.190 \mathrm{E}-05$ & $8.65 \mathrm{E}-06$ & 0.40 & 0.015 \\
\hline 21 & Apr24_4 & $2.04 \mathrm{E}-05$ & 22.4 & 96.0 & 2.167E-05 & $4.23 \mathrm{E}-06$ & 0.20 & 1.482 \\
\hline 22 & Apr24_5 & $2.05 \mathrm{E}-05$ & 22.4 & 95.9 & $2.169 \mathrm{E}-05$ & 4.44E-06 & 0.20 & 1.410 \\
\hline 23 & Apr24_6 & $2.09 \mathrm{E}-05$ & 22.5 & 95.9 & 2.171E-05 & $6.21 \mathrm{E}-06$ & 0.29 & 0.801 \\
\hline 24 & Apr24_7 & $2.13 \mathrm{E}-05$ & 22.6 & 95.9 & 2.172E-05 & $8.64 \mathrm{E}-06$ & 0.40 & 0.034 \\
\hline 25 & Apr24_8 & $2.14 \mathrm{E}-05$ & 22.7 & 95.9 & $2.174 \mathrm{E}-05$ & $1.03 \mathrm{E}-05$ & 0.47 & 0.612 \\
\hline 26 & Apr25_5 & $2.07 \mathrm{E}-05$ & 22.6 & 96.0 & $2.170 \mathrm{E}-05$ & $5.14 \mathrm{E}-06$ & 0.24 & 1.168 \\
\hline 27 & Apr25_6 & $2.11 \mathrm{E}-05$ & 22.8 & 96.0 & $2.172 \mathrm{E}-05$ & $7.06 \mathrm{E}-06$ & 0.33 & 0.508 \\
\hline 28 & Apr25_7 & $2.12 \mathrm{E}-05$ & 22.8 & 96.0 & 2.172E-05 & 7.96E-06 & 0.37 & 0.198 \\
\hline 29 & Apr25_8 & $2.13 \mathrm{E}-05$ & 22.7 & 96.0 & $2.172 \mathrm{E}-05$ & $9.95 \mathrm{E}-06$ & 0.46 & 0.487 \\
\hline \multirow[t]{4}{*}{30} & Apr25_9 & $2.12 \mathrm{E}-05$ & 22.7 & 96.0 & $2.172 \mathrm{E}-05$ & $7.88 \mathrm{E}-06$ & 0.36 & 0.228 \\
\hline & & & & & Average & $8.54 \mathrm{E}-06$ & 0.39 & \\
\hline & & & & & Std. Dev. & $2.91 \mathrm{E}-06$ & 0.134 & \\
\hline & & & & & 95\% C.I. & $1.1 \mathrm{E}-06$ & 0.052 & \\
\hline
\end{tabular}




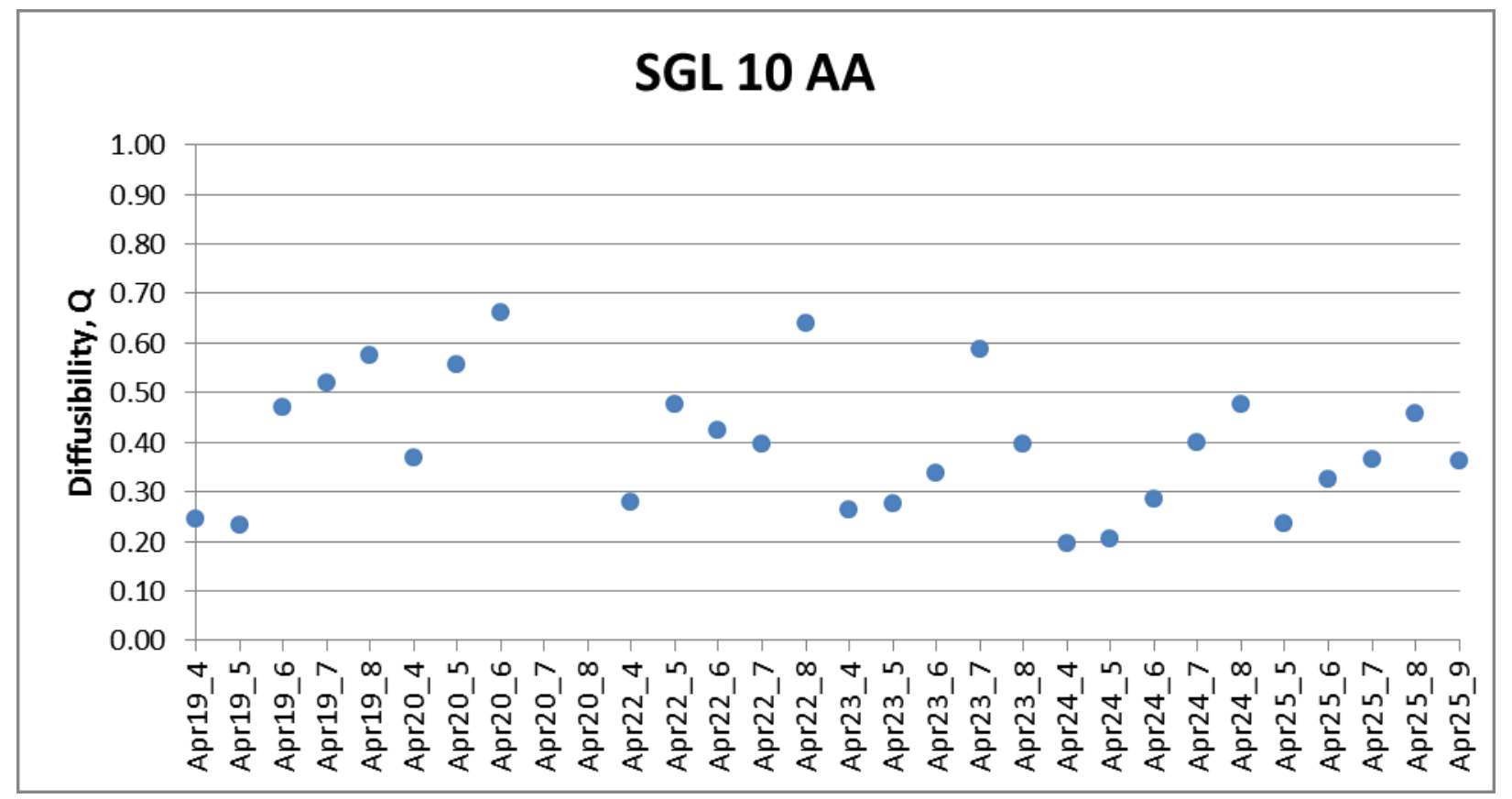




\begin{tabular}{|c|c|c|c|c|c|c|c|c|}
\hline & \multicolumn{2}{|l|}{ SGL 10 BA } & \multirow[b]{2}{*}{$+/-0.4 \%$} & & & & & \\
\hline & \begin{tabular}{|l|} 
Porosity (\%) \\
\end{tabular} & $81.83 \%$ & & & & & & \\
\hline & GDL thickness (m) & 0.00037 & $+/-0.00001$ & & & & & \\
\hline & Sensor Distance $(\mathrm{m})$ & 0.0265 & & & & & & \\
\hline $\mathbf{N}$ & Trial & $D_{\text {eq }}$ & \begin{tabular}{|c|} 
Average \\
Temperature \\
$\left({ }^{\circ} \mathrm{C}\right)$ \\
\end{tabular} & $\begin{array}{c}\text { Average } \\
\text { Pressure }(\mathrm{kPa})\end{array}$ & $\begin{array}{l}\text { Literature } \\
\text { Value }\end{array}$ & $D_{\text {eff }}$ & Q & $\tau_{\max }$ \\
\hline 1 & Apr30_5 & $2.04 \mathrm{E}-05$ & 24.0 & 96.5 & 2.177E-05 & $3.85 \mathrm{E}-06$ & 0.18 & 1.933 \\
\hline 2 & Apr30_6 & $2.11 \mathrm{E}-05$ & 24.2 & 96.5 & $2.179 \mathrm{E}-05$ & $6.67 \mathrm{E}-06$ & 0.31 & 0.560 \\
\hline 3 & Apr30_7 & Z.19E-05 & 24.5 & 96.5 & $2.182 E-05$ & $z .72 E-05$ & 1.25 & 9.426 \\
\hline 4 & May02_4 & 2.14E-05 & 25.8 & 96.0 & 2.210E-05 & $6.97 \mathrm{E}-06$ & 0.32 & 0.465 \\
\hline 5 & May02_5 & $2.16 \mathrm{E}-05$ & 25.8 & 96.0 & 2.209E-05 & 8.31E-06 & 0.38 & 0.179 \\
\hline 6 & May02_6 & $2.16 \mathrm{E}-05$ & 25.8 & 96.1 & $2.209 \mathrm{E}-05$ & $8.90 \mathrm{E}-06$ & 0.40 & 0.466 \\
\hline 7 & May02_7 & $2.17 \mathrm{E}-05$ & 25.9 & 96.1 & $2.209 \mathrm{E}-05$ & $9.49 \mathrm{E}-06$ & 0.43 & 0.750 \\
\hline 8 & AayyOz_8 & $Z .22 E-05$ & 26.0 & 96.0 & $2.212 E-05$ & $3.72 E-05$ & 1.68 & 14.022 \\
\hline 9 & May03_4 & $2.13 \mathrm{E}-05$ & 25.5 & 96.3 & $2.200 \mathrm{E}-05$ & $6.33 \mathrm{E}-06$ & 0.29 & 0.758 \\
\hline 10 & May03_5 & $2.16 \mathrm{E}-05$ & 25.5 & 96.2 & $2.201 \mathrm{E}-05$ & $8.78 \mathrm{E}-06$ & 0.40 & 0.420 \\
\hline 11 & May03_6 & $2.16 \mathrm{E}-05$ & 25.4 & 96.2 & $2.201 \mathrm{E}-05$ & 9.07E-06 & 0.41 & 0.563 \\
\hline 12 & May03_7 & 2.17E-05 & 25.4 & 96.1 & $2.203 \mathrm{E}-05$ & 1.09E-05 & 0.49 & 1.436 \\
\hline 13 & Alay03_8 & $Z .19 E-05$ & 25.4 & 96.2 & Z.201E-05 & $1.81 E-05$ & 0.82 & 4.929 \\
\hline 14 & May04_4 & $2.08 \mathrm{E}-05$ & 24.7 & 96.5 & $2.185 \mathrm{E}-05$ & $4.59 \mathrm{E}-06$ & 0.21 & 1.581 \\
\hline 15 & May04_5 & $2.11 \mathrm{E}-05$ & 24.9 & 96.5 & 2.187E-05 & $6.15 \mathrm{E}-06$ & 0.28 & 0.828 \\
\hline 16 & May04_6 & $2.14 \mathrm{E}-05$ & 25.1 & 96.5 & $2.190 \mathrm{E}-05$ & $7.85 \mathrm{E}-06$ & 0.36 & 0.006 \\
\hline 17 & Aay04_7 & Z.24E-05 & 25.4 & 96.5 & Z.194E-05 & $-6.57 \pm-05$ & -2.99 & 35.546 \\
\hline 18 & Alay04_8 & $z .29 E-05$ & 25.7 & 96.5 & Z.198E-05 & 1.18E-05 & -0.54 & 9.497 \\
\hline 19 & May05_4 & $2.08 \mathrm{E}-05$ & 23.2 & 96.5 & $2.166 \mathrm{E}-05$ & $5.42 \mathrm{E}-06$ & 0.25 & 1.152 \\
\hline 20 & May05_5 & $2.10 \mathrm{E}-05$ & 23.1 & 96.5 & $2.165 \mathrm{E}-05$ & $6.32 \mathrm{E}-06$ & 0.29 & 0.712 \\
\hline 21 & May05_6 & $2.13 \mathrm{E}-05$ & 23.1 & 96.5 & $2.165 \mathrm{E}-05$ & $1.01 \mathrm{E}-05$ & 0.46 & 1.116 \\
\hline 22 & May05_7 & $2.12 \mathrm{E}-05$ & 23.1 & 96.5 & $2.165 \mathrm{E}-05$ & $8.51 \mathrm{E}-06$ & 0.39 & 0.361 \\
\hline 23 & May05_8 & $2.12 \mathrm{E}-05$ & 23.1 & 96.5 & $2.166 \mathrm{E}-05$ & 7.93E-06 & 0.37 & 0.076 \\
\hline 24 & May05_9 & $2.13 \mathrm{E}-05$ & 23.1 & 96.4 & $2.168 \mathrm{E}-05$ & 9.07E-06 & 0.42 & 0.631 \\
\hline 25 & May05_10 & $2.15 \mathrm{E}-05$ & 23.2 & 96.4 & 2.169E-05 & $1.19 \mathrm{E}-05$ & 0.55 & 1.998 \\
\hline & & & & & Average & $7.85 \mathrm{E}-06$ & 0.36 & \\
\hline & & & & & Std. Dev. & $2.06 \mathrm{E}-06$ & 0.094 & \\
\hline & & & & & 95\% C.I. & 9.7E-07 & 0.044 & \\
\hline
\end{tabular}




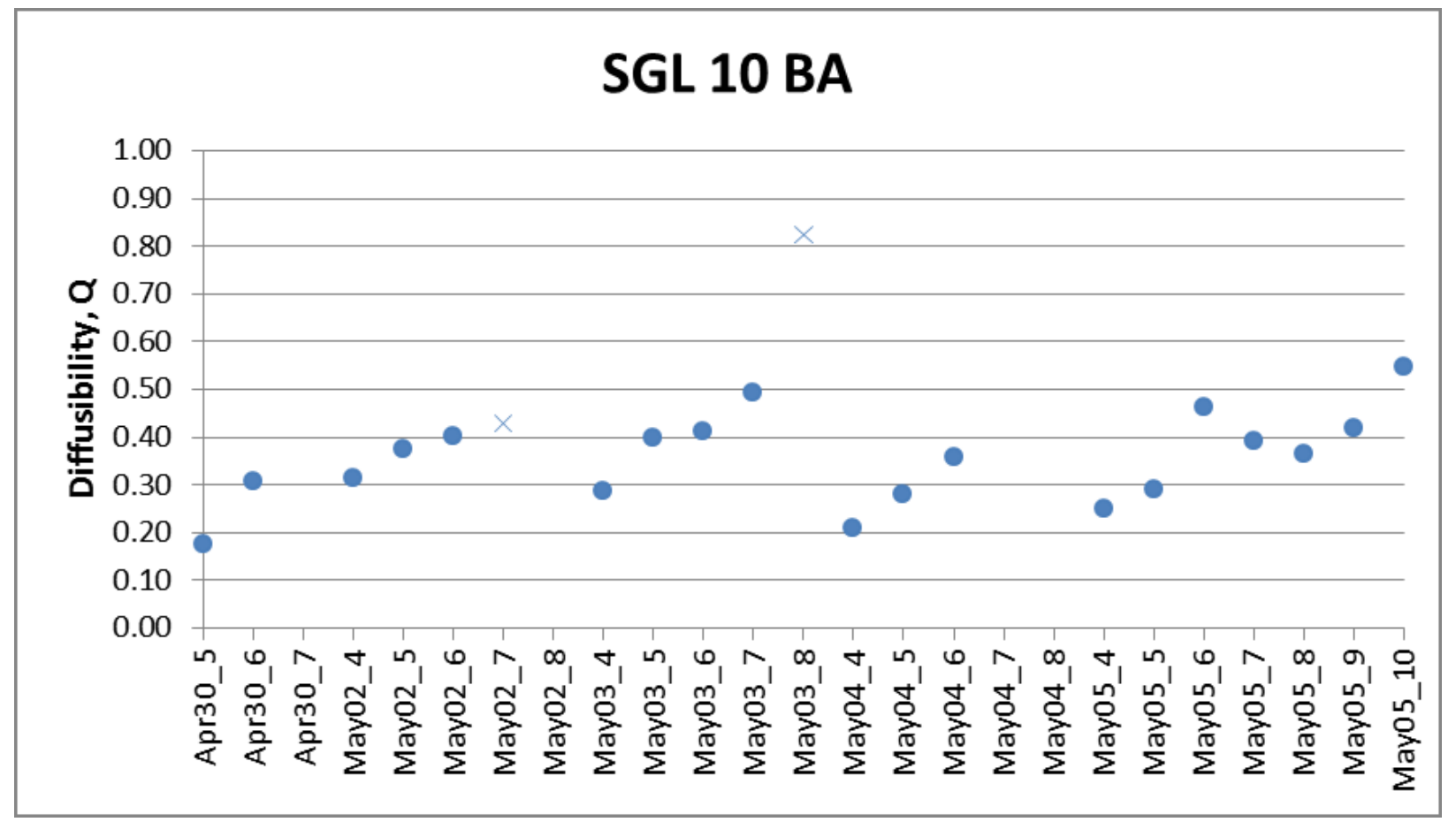




\begin{tabular}{|c|c|c|c|c|c|c|c|c|}
\hline & \multicolumn{2}{|l|}{ SGL 25 DC } & \multirow[b]{2}{*}{$+/-0.3 \%$} & & & & & \\
\hline & \begin{tabular}{|l|} 
Porosity (\%) \\
\end{tabular} & $81.83 \%$ & & & & & & \\
\hline & GDL thickness (m) & 0.00025 & $+/-0.00001$ & & & & & \\
\hline & Sensor Distance $(\mathrm{m})$ & 0.0273 & & & & & & \\
\hline $\mathbf{N}$ & Trial & $D_{\text {eq }}$ & \begin{tabular}{|c|} 
Average \\
Temperature \\
$\left({ }^{\circ} \mathrm{C}\right)$ \\
\end{tabular} & $\begin{array}{c}\text { Average } \\
\text { Pressure (kPa) }\end{array}$ & $\begin{array}{l}\text { Literature } \\
\text { Value }\end{array}$ & $D_{\text {eff }}$ & Q & $\tau_{\max }$ \\
\hline 1 & May06_4 & 2.03E-05 & 23.2 & 95.2 & 2.196E-05 & $2.15 \mathrm{E}-06$ & 0.10 & 1.535 \\
\hline 2 & May06_5 & $2.06 \mathrm{E}-05$ & 23.3 & 95.2 & 2.197E-05 & 2.74E-06 & 0.12 & 0.555 \\
\hline 3 & May06_6 & 2.07E-05 & 23.3 & 95.1 & 2.199E-05 & $2.76 \mathrm{E}-06$ & 0.13 & 0.524 \\
\hline 4 & May07_4 & $2.03 \mathrm{E}-05$ & 22.8 & 95.4 & 2.187E-05 & $2.39 \mathrm{E}-06$ & 0.11 & 1.120 \\
\hline 5 & May07_5 & 2.07E-05 & 23.0 & 95.4 & $2.189 \mathrm{E}-05$ & $3.02 \mathrm{E}-06$ & 0.14 & 0.052 \\
\hline 6 & May07_6 & 2.10E-05 & 23.2 & 95.4 & 2.191E-05 & $4.01 \mathrm{E}-06$ & 0.18 & 1.630 \\
\hline 7 & May07_7 & $2.10 \mathrm{E}-05$ & 23.2 & 95.4 & $2.190 \mathrm{E}-05$ & 3.74E-06 & 0.17 & 1.167 \\
\hline 8 & May07_8 & $2.10 \mathrm{E}-05$ & 23.2 & 95.4 & 2.190E-05 & $3.72 \mathrm{E}-06$ & 0.17 & 1.130 \\
\hline 9 & May08_4 & $2.04 \mathrm{E}-05$ & 22.9 & 96.0 & $2.173 \mathrm{E}-05$ & $2.70 \mathrm{E}-06$ & 0.12 & 0.562 \\
\hline 10 & May08_5 & $2.06 \mathrm{E}-05$ & 22.9 & 96.0 & 2.173E-05 & $3.00 \mathrm{E}-06$ & 0.14 & 0.052 \\
\hline 11 & May08_6 & $2.08 \mathrm{E}-05$ & 22.9 & 96.0 & $2.173 \mathrm{E}-05$ & $3.72 \mathrm{E}-06$ & 0.17 & 1.175 \\
\hline 12 & May08_7 & 2.09E-05 & 22.9 & 96.0 & 2.173E-05 & 3.99E-06 & 0.18 & 1.643 \\
\hline 13 & May08_8 & $2.07 \mathrm{E}-05$ & 23.0 & 96.0 & 2.174E-05 & $3.24 \mathrm{E}-06$ & 0.15 & 0.364 \\
\hline 14 & May09_4 & $2.03 \mathrm{E}-05$ & 23.3 & 96.3 & $2.173 \mathrm{E}-05$ & $2.56 \mathrm{E}-06$ & 0.12 & 0.805 \\
\hline 15 & May09_5 & $2.04 \mathrm{E}-05$ & 23.4 & 96.3 & $2.173 \mathrm{E}-05$ & $2.71 \mathrm{E}-06$ & 0.12 & 0.541 \\
\hline 16 & May09_6 & $2.03 \mathrm{E}-05$ & 23.4 & 96.3 & $2.173 \mathrm{E}-05$ & $2.49 \mathrm{E}-06$ & 0.11 & 0.916 \\
\hline 17 & May09_7 & $2.05 \mathrm{E}-05$ & 23.4 & 96.3 & $2.174 \mathrm{E}-05$ & $2.77 \mathrm{E}-06$ & 0.13 & 0.447 \\
\hline & & & & & Average & $3.04 \mathrm{E}-06$ & 0.14 & \\
\hline & & & & & Std. Dev. & $5.87 \mathrm{E}-07$ & 0.027 & \\
\hline & & & & & 95\% C.I. & $3.0 \mathrm{E}-07$ & 0.014 & \\
\hline
\end{tabular}

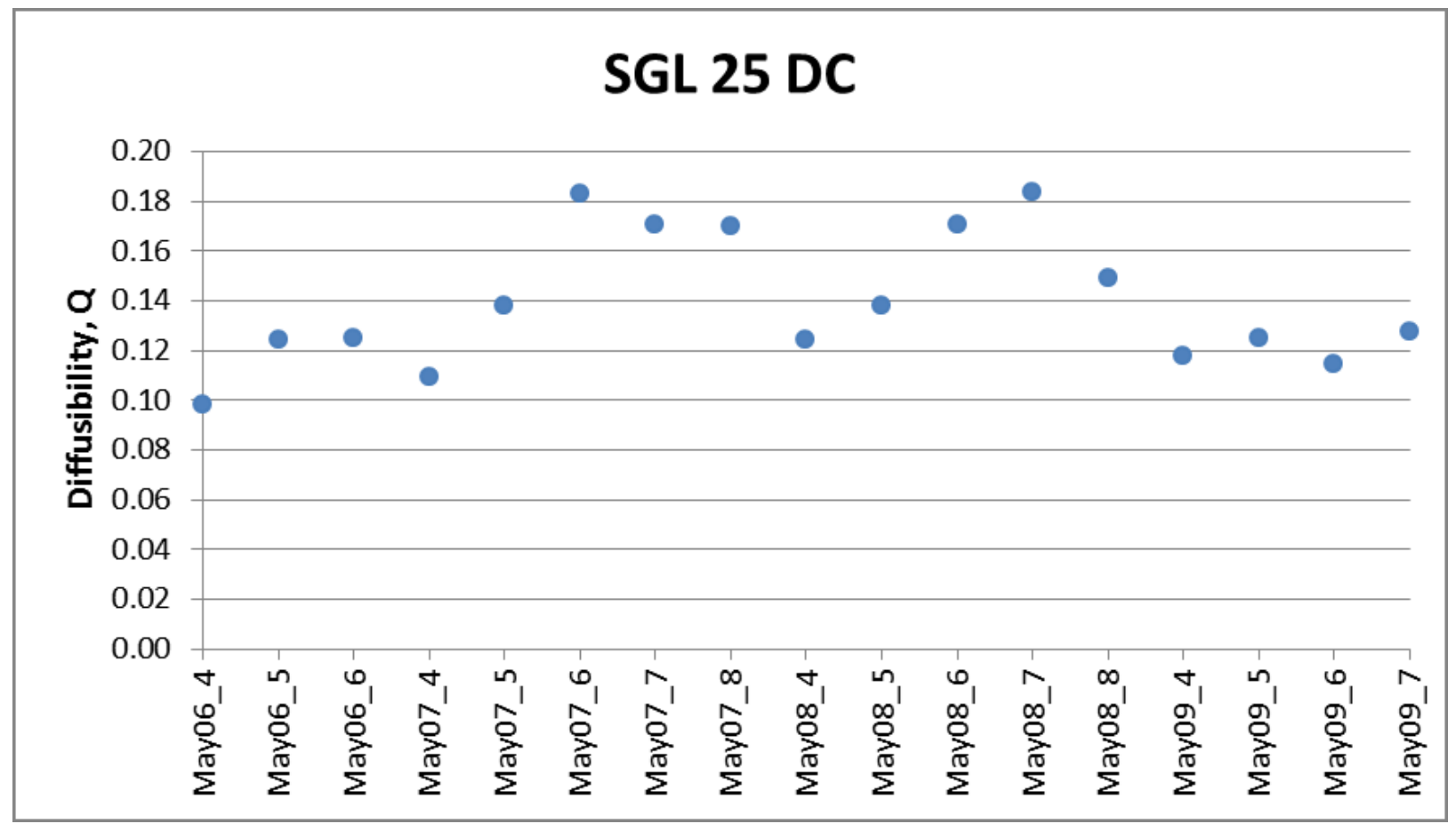




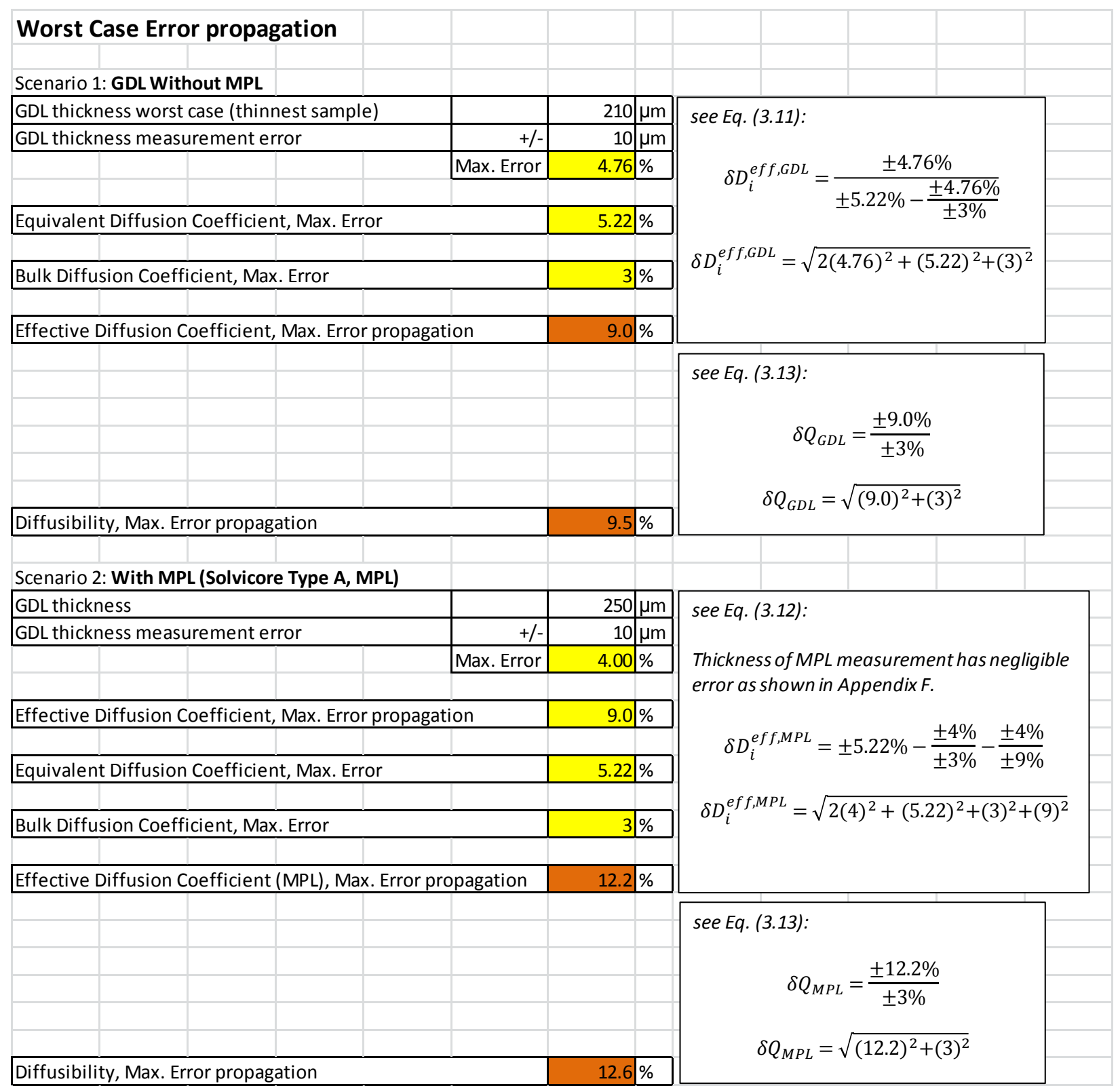




\section{Appendix F}

\section{SEM Images for MPL Thickness}

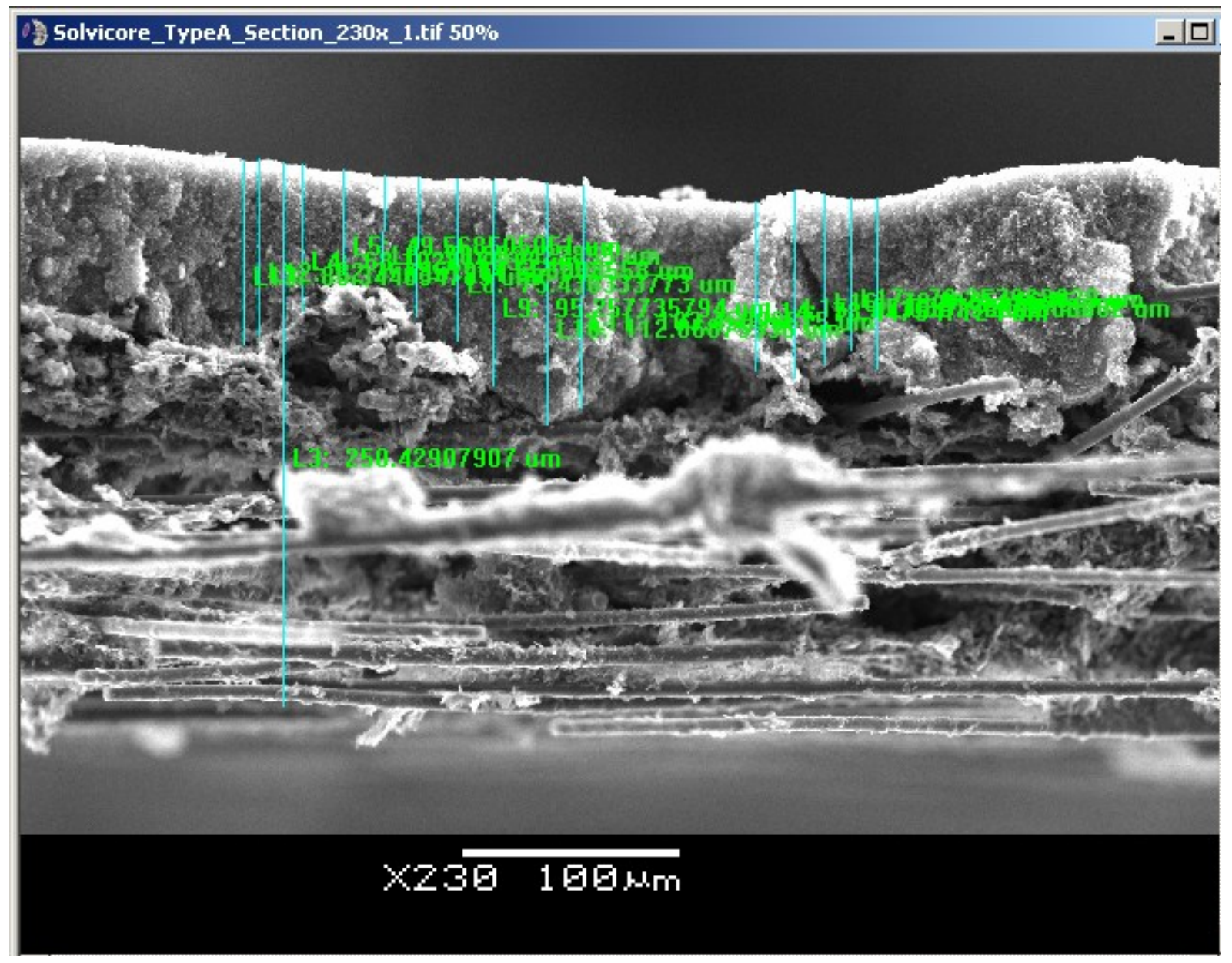

\begin{tabular}{|c|c|c|c|c|c|c|c|}
\hline & Features & Measurement & Value & Nominal Val. & Min. Tol. & Max. Tol. & Pass / Fail \\
\hline 1 & L3 & Length & 250.4290791 & 250.4291 & -0.002504 & 0.0025042 & Pass \\
\hline 2 & L4 & Length & 68.10281564 & 68.10282 & -0.000681 & 0.000681 & Pass \\
\hline 3 & L5 & Length & 49.56850505 & 49.56851 & -0.000495 & 0.0004956 & Pass \\
\hline 4 & L6 & Length & 50.86342286 & 50.86342 & -0.000508 & 0.0005086 & Pass \\
\hline 5 & L7 & Length & 64.65600856 & 64.65601 & -0.000646 & 0.0006465 & Pass \\
\hline 6 & L8 & Length & 75.43033377 & 75.43033 & -0.000754 & 0.0007543 & Pass \\
\hline 7 & L9 & Length & 95.25773579 & 95.25774 & -0.000952 & 0.0009525 & Pass \\
\hline 8 & L10 & Length & 112.0687534 & 112.0688 & -0.00112 & 0.0011206 & Pass \\
\hline 9 & L11 & Length & 103.4509068 & 103.4509 & -0.001034 & 0.0010345 & Pass \\
\hline 10 & L12 & Length & 82.75785191 & 82.75785 & -0.000827 & 0.0008275 & Pass \\
\hline 11 & L13 & Length & 85.34403478 & 85.34403 & -0.000853 & 0.0008534 & Pass \\
\hline 12 & L14 & Length & 78.44754712 & 78.44755 & -0.000784 & 0.0007844 & Pass \\
\hline 13 & L15 & Length & 87.0681567 & 87.06816 & -0.00087 & 0.0008706 & Pass \\
\hline 14 & L16 & Length & 78.01651665 & 78.01652 & -0.00078 & 0.0007801 & Pass \\
\hline 15 & L17 & Length & 70.25796803 & 70.25797 & -0.000702 & 0.0007025 & Pass \\
\hline 16 & L18 & Length & 79.30960808 & 79.30961 & -0.000793 & 0.000793 & Pass \\
\hline
\end{tabular}




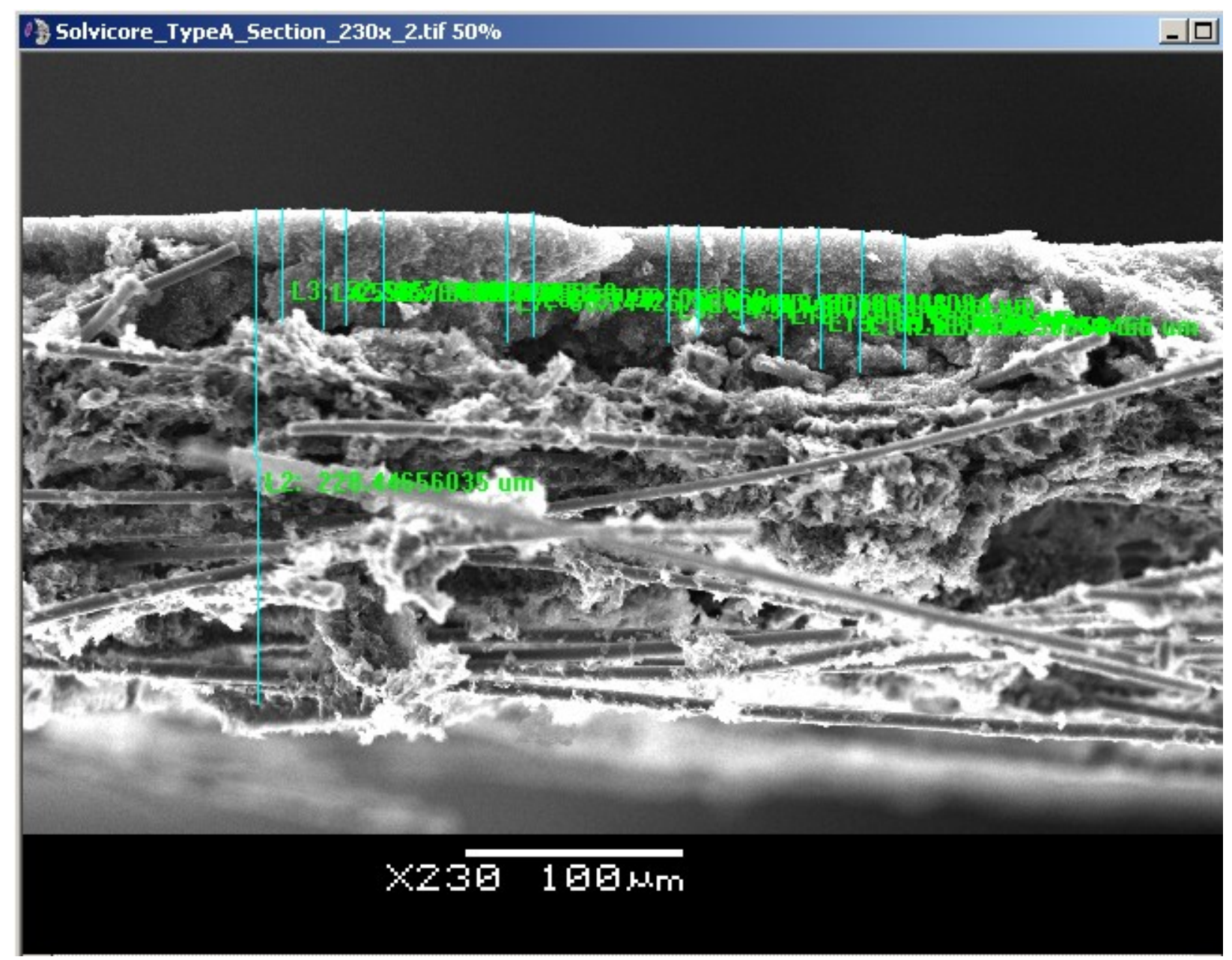

\begin{tabular}{|c|c|c|c|c|c|c|c|}
\hline & Features & Measurement & Value & Nominal Val. & Min. Tol. & Max. Tol. & Pass / Fail \\
\hline 1 & L2 & Length & 228.4465604 & 228.4466 & -0.002284 & 0.0022844 & Pass \\
\hline 2 & L3 & Length & 52.5857184 & 52.58572 & -0.000525 & 0.0005258 & Pass \\
\hline 3 & L4 & Length & 56.46499271 & 56.46499 & -0.000564 & 0.0005646 & Pass \\
\hline 4 & L5 & Length & 54.30984032 & 54.30984 & -0.000543 & 0.000543 & Pass \\
\hline 5 & L6 & Length & 53.44777936 & 53.44778 & -0.000534 & 0.0005344 & Pass \\
\hline 6 & L7 & Length & 60.34426702 & 60.34427 & -0.000603 & 0.0006034 & Pass \\
\hline 7 & L8 & Length & 57.32705367 & 57.32705 & -0.000573 & 0.0005732 & Pass \\
\hline 8 & L9 & Length & 54.31155073 & 54.31155 & -0.000543 & 0.0005431 & Pass \\
\hline 9 & L10 & Length & 50.43056601 & 50.43057 & -0.000504 & 0.0005043 & Pass \\
\hline 10 & L11 & Length & 48.70644409 & 48.70644 & -0.000487 & 0.000487 & Pass \\
\hline 11 & L12 & Length & 59.05117558 & 59.05118 & -0.00059 & 0.0005905 & Pass \\
\hline 12 & L13 & Length & 65.51805061 & 65.51805 & -0.000655 & 0.0006551 & Pass \\
\hline 13 & L14 & Length & 65.51805061 & 65.51805 & -0.000655 & 0.0006551 & Pass \\
\hline 14 & L15 & Length & 61.63735846 & 61.63736 & -0.000616 & 0.0006163 & Pass \\
\hline
\end{tabular}




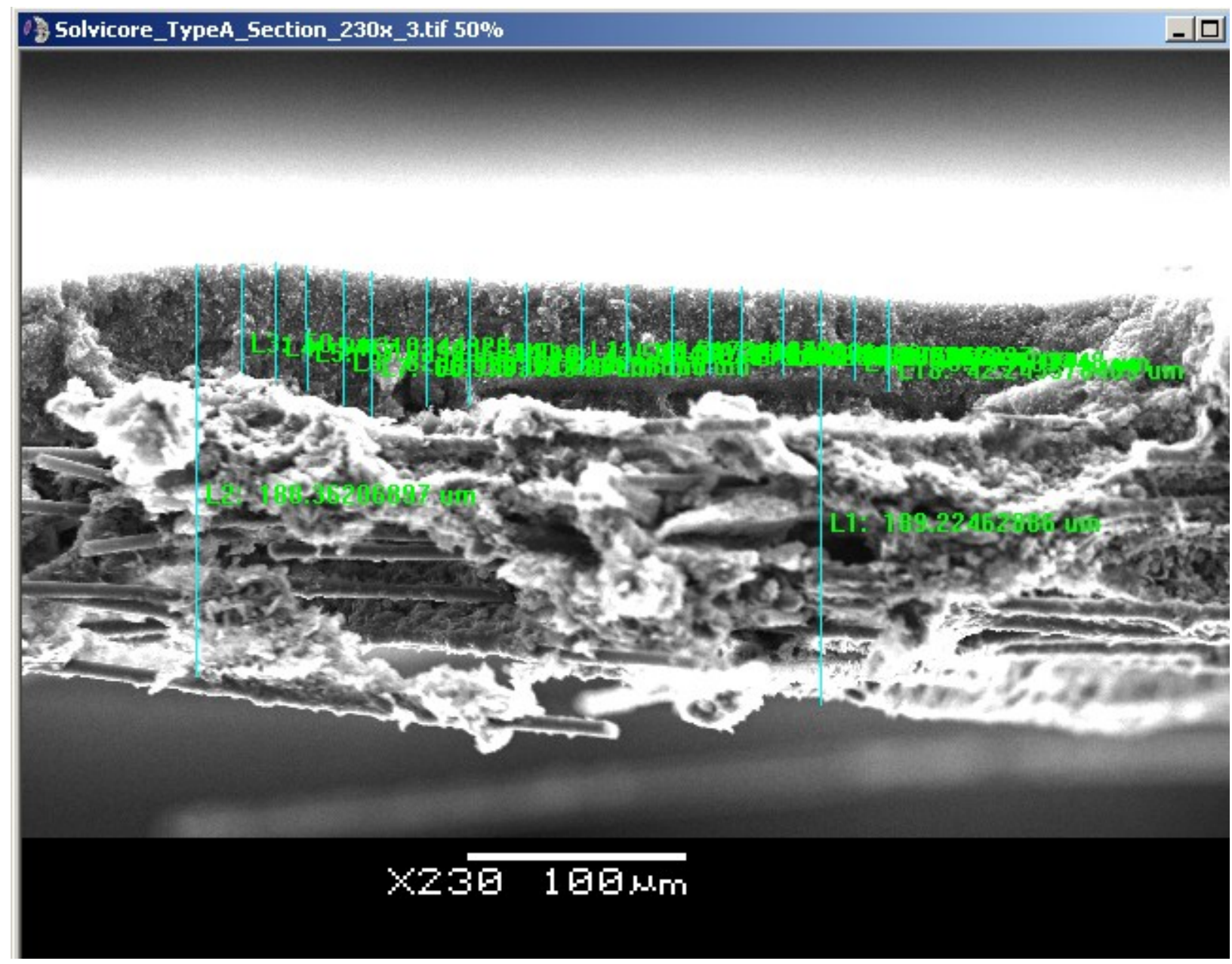

\begin{tabular}{|c|c|c|c|c|c|c|c|}
\hline & Features & Measurement & Value & Nominal Val. & Min. Tol. & Max. Tol. & Pass / Fail \\
\hline 1 & L1 & Length & 189.2246289 & 189.2246 & -0.001892 & 0.0018922 & Pass \\
\hline 2 & L2 & Length & 188.362069 & 188.3621 & -0.001883 & 0.0018836 & Pass \\
\hline 3 & L3 & Length & 50 & 50 & -0.0005 & 0.0005 & Pass \\
\hline 4 & L4 & Length & 54.31034483 & 54.31034 & -0.000543 & 0.0005431 & Pass \\
\hline 5 & L5 & Length & 57.32920661 & 57.32921 & -0.000573 & 0.0005732 & Pass \\
\hline 6 & L6 & Length & 62.06896552 & 62.06897 & -0.00062 & 0.0006206 & Pass \\
\hline 7 & L7 & Length & 66.37931035 & 66.37931 & -0.000663 & 0.0006637 & Pass \\
\hline 8 & L8 & Length & 59.05329724 & 59.0533 & -0.00059 & 0.0005905 & Pass \\
\hline 9 & L9 & Length & 58.62068966 & 58.62069 & -0.000586 & 0.0005862 & Pass \\
\hline 10 & L10 & Length & 43.53448276 & 43.53448 & -0.000435 & 0.0004353 & Pass \\
\hline 11 & L11 & Length & 40.51724138 & 40.51724 & -0.000405 & 0.0004051 & Pass \\
\hline 12 & L12 & Length & 39.22413793 & 39.22414 & -0.000392 & 0.0003922 & Pass \\
\hline 13 & L13 & Length & 40.94827586 & 40.94828 & -0.000409 & 0.0004094 & Pass \\
\hline 14 & L14 & Length & 39.22413793 & 39.22414 & -0.000392 & 0.0003922 & Pass \\
\hline 15 & L15 & Length & 40.94827586 & 40.94828 & -0.000409 & 0.0004094 & Pass \\
\hline 16 & L16 & Length & 40.0862069 & 40.08621 & -0.0004 & 0.0004008 & Pass \\
\hline 17 & L17 & Length & 38.79310345 & 38.7931 & -0.000387 & 0.0003879 & Pass \\
\hline 18 & L18 & Length & 42.24357841 & 42.24358 & -0.000422 & 0.0004224 & Pass \\
\hline
\end{tabular}




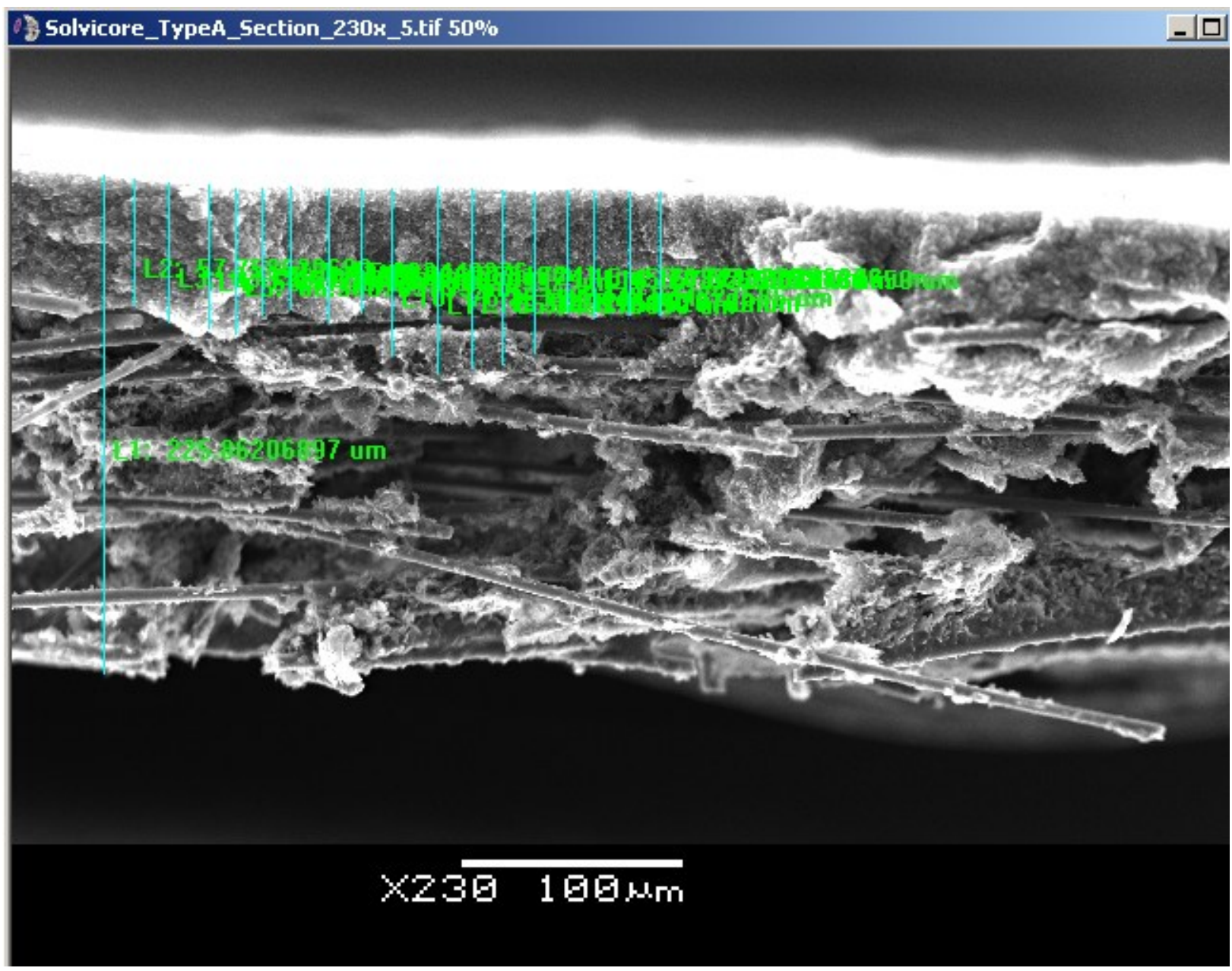

\begin{tabular}{|c|c|c|c|c|c|c|c|}
\hline & Features & Measurement & Value & Nominal Val. & Min. Tol. & Max. Tol. & Pass / Fail \\
\hline 1 & L1 & Length & 225.862069 & 225.8621 & -0.002258 & 0.0022586 & Pass \\
\hline 2 & L2 & Length & 57.75862069 & 57.75862 & -0.000577 & 0.0005775 & Pass \\
\hline 3 & L3 & Length & 63.79310345 & 63.7931 & -0.000637 & 0.0006379 & Pass \\
\hline 4 & L4 & Length & 65.51724138 & 65.51724 & -0.000655 & 0.0006551 & Pass \\
\hline 5 & L5 & Length & 66.38070979 & 66.38071 & -0.000663 & 0.0006638 & Pass \\
\hline 6 & L6 & Length & 57.75862069 & 57.75862 & -0.000577 & 0.0005775 & Pass \\
\hline 7 & L7 & Length & 55.60344828 & 55.60345 & -0.000556 & 0.000556 & Pass \\
\hline 8 & L8 & Length & 61.20689655 & 61.2069 & -0.000612 & 0.000612 & Pass \\
\hline 9 & L9 & Length & 56.46551724 & 56.46552 & -0.000564 & 0.0005646 & Pass \\
\hline 10 & L10 & Length & 76.29310345 & 76.2931 & -0.000762 & 0.0007629 & Pass \\
\hline 11 & L11 & Length & 85.34591605 & 85.34592 & -0.000853 & 0.0008534 & Pass \\
\hline 12 & L12 & Length & 82.32758621 & 82.32759 & -0.000823 & 0.0008232 & Pass \\
\hline 13 & L13 & Length & 79.31151611 & 79.31152 & -0.000793 & 0.0007931 & Pass \\
\hline 14 & L14 & Length & 72.84482759 & 72.84483 & -0.000728 & 0.0007284 & Pass \\
\hline 15 & L15 & Length & 56.03448276 & 56.03448 & -0.00056 & 0.0005603 & Pass \\
\hline 16 & L16 & Length & 57.32758621 & 57.32759 & -0.000573 & 0.0005732 & Pass \\
\hline 17 & L17 & Length & 55.60344828 & 55.60345 & -0.000556 & 0.000556 & Pass \\
\hline 18 & L18 & Length & 56.03448276 & 56.03448 & -0.00056 & 0.0005603 & Pass \\
\hline
\end{tabular}


Analysis of MPL Thickness for SolviCore Type A, MPL from SEM images

\begin{tabular}{|c|c|c|c|c|}
\hline$i$ & MPL Thickness $\left(t_{i}\right)$ & Frequency $(N)$ & $t_{i} \times N$ & \\
\hline 1 & 38.8 & 1 & 38.8 & \multirow{2}{*}{$\begin{array}{l}\text { Average Thickness } \\
=\Sigma\left(t_{i} \times N\right) / \Sigma N\end{array}$} \\
\hline 2 & 46.9 & 8 & 375.5 & \\
\hline 3 & 55.1 & 10 & 550.8 & 66.4 \\
\hline 4 & 63.2 & 18 & 1137.9 & \\
\hline 5 & 71.4 & 9 & 642.2 & \\
\hline 6 & 79.5 & 7 & 556.5 & \\
\hline 7 & 87.6 & 5 & 438.2 & \\
\hline 8 & 95.8 & 1 & 95.8 & \\
\hline 9 & 103.9 & 1 & 103.9 & \\
\hline 10 & 112.2 & 1 & 112.2 & \\
\hline
\end{tabular}

Distribution of MPL Thickness

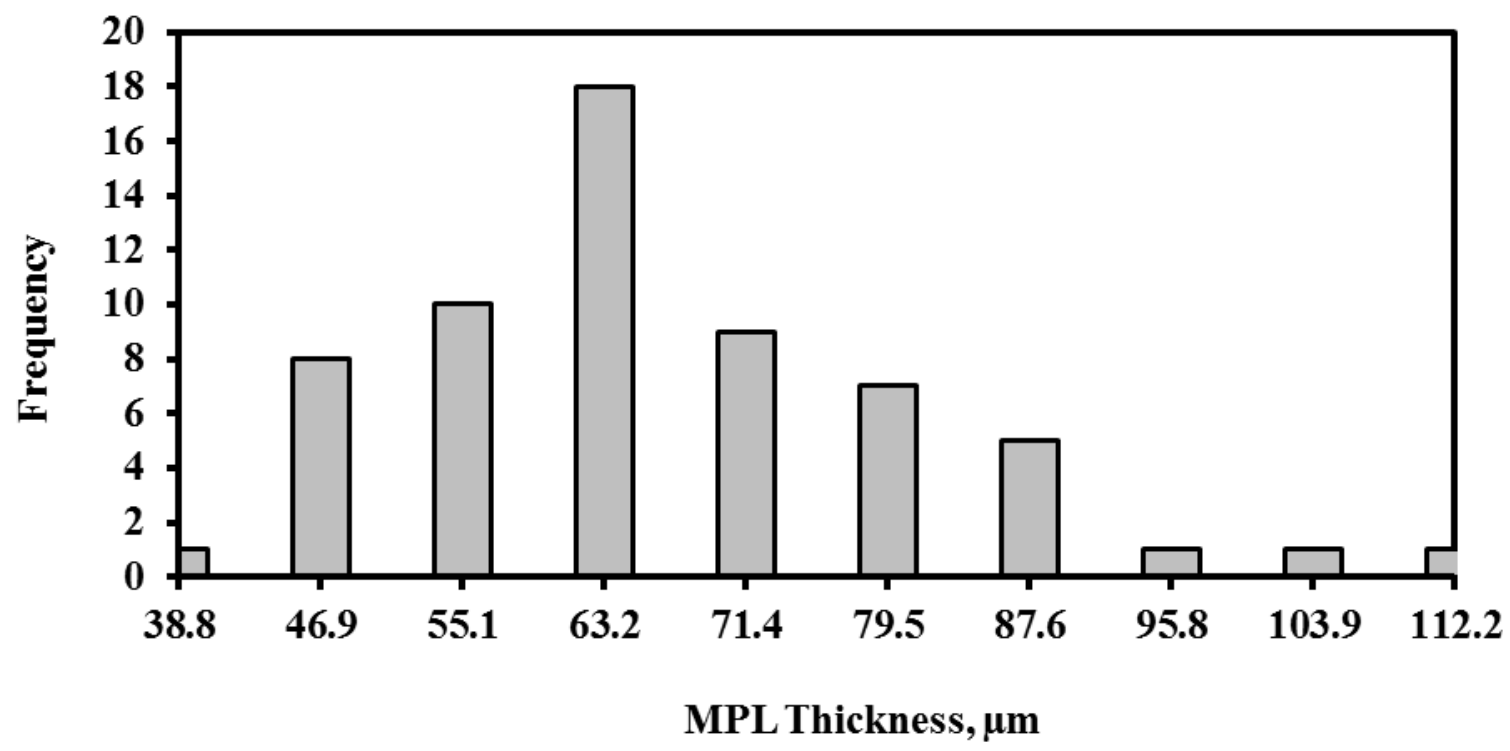




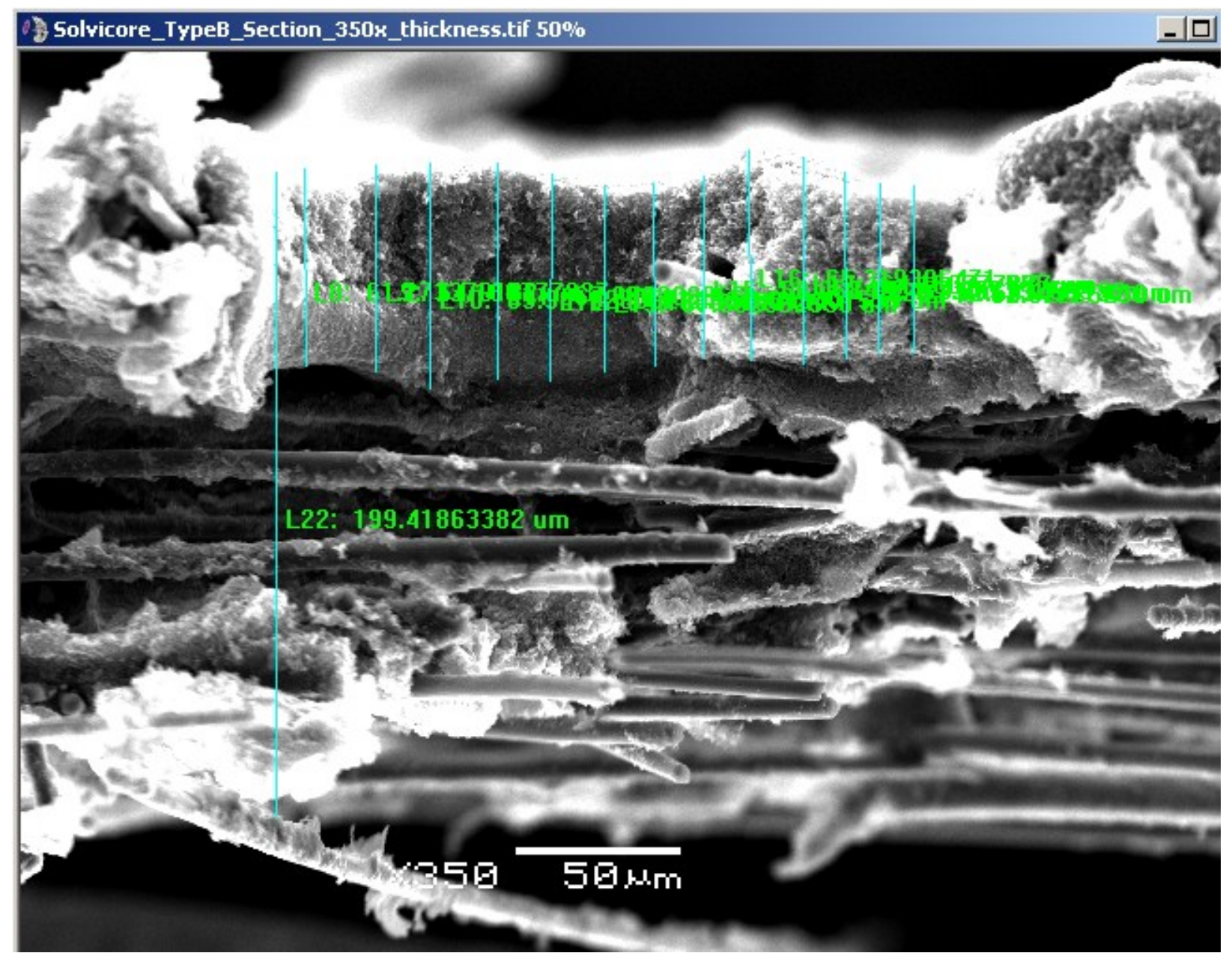

\begin{tabular}{|c|c|c|c|c|c|c|c|}
\hline & Features & Measurement & Value & Nominal Val. & Min. Tol. & Max. Tol. & Pass / Fail \\
\hline 1 & L8 & Length & 61.27337918 & 61.27338 & -0.000612 & 0.0006127 & Pass \\
\hline 2 & L9 & Length & 64.16077784 & 64.16078 & -0.000641 & 0.0006416 & Pass \\
\hline 3 & L10 & Length & 69.94102809 & 69.94103 & -0.000699 & 0.0006994 & Pass \\
\hline 4 & L11 & Length & 67.05090297 & 67.0509 & -0.00067 & 0.0006705 & Pass \\
\hline 5 & L12 & Length & 64.1633815 & 64.16338 & -0.000641 & 0.0006416 & Pass \\
\hline 6 & L13 & Length & 57.80250256 & 57.8025 & -0.000578 & 0.000578 & Pass \\
\hline 7 & L14 & Length & 56.64940154 & 56.6494 & -0.000566 & 0.0005664 & Pass \\
\hline 8 & L15 & Length & 56.06842748 & 56.06843 & -0.00056 & 0.0005606 & Pass \\
\hline 9 & L16 & Length & 65.31938547 & 65.31939 & -0.000653 & 0.0006531 & Pass \\
\hline 10 & L17 & Length & 64.16077784 & 64.16078 & -0.000641 & 0.0006416 & Pass \\
\hline 11 & L19 & Length & 57.80539261 & 57.80539 & -0.000578 & 0.000578 & Pass \\
\hline 12 & L20 & Length & 52.60345319 & 52.60345 & -0.000526 & 0.000526 & Pass \\
\hline 13 & L21 & Length & 52.0222523 & 52.02225 & -0.00052 & 0.0005202 & Pass \\
\hline 14 & L22 & Length & 199.4186338 & 199.4186 & -0.001994 & 0.0019941 & Pass \\
\hline
\end{tabular}




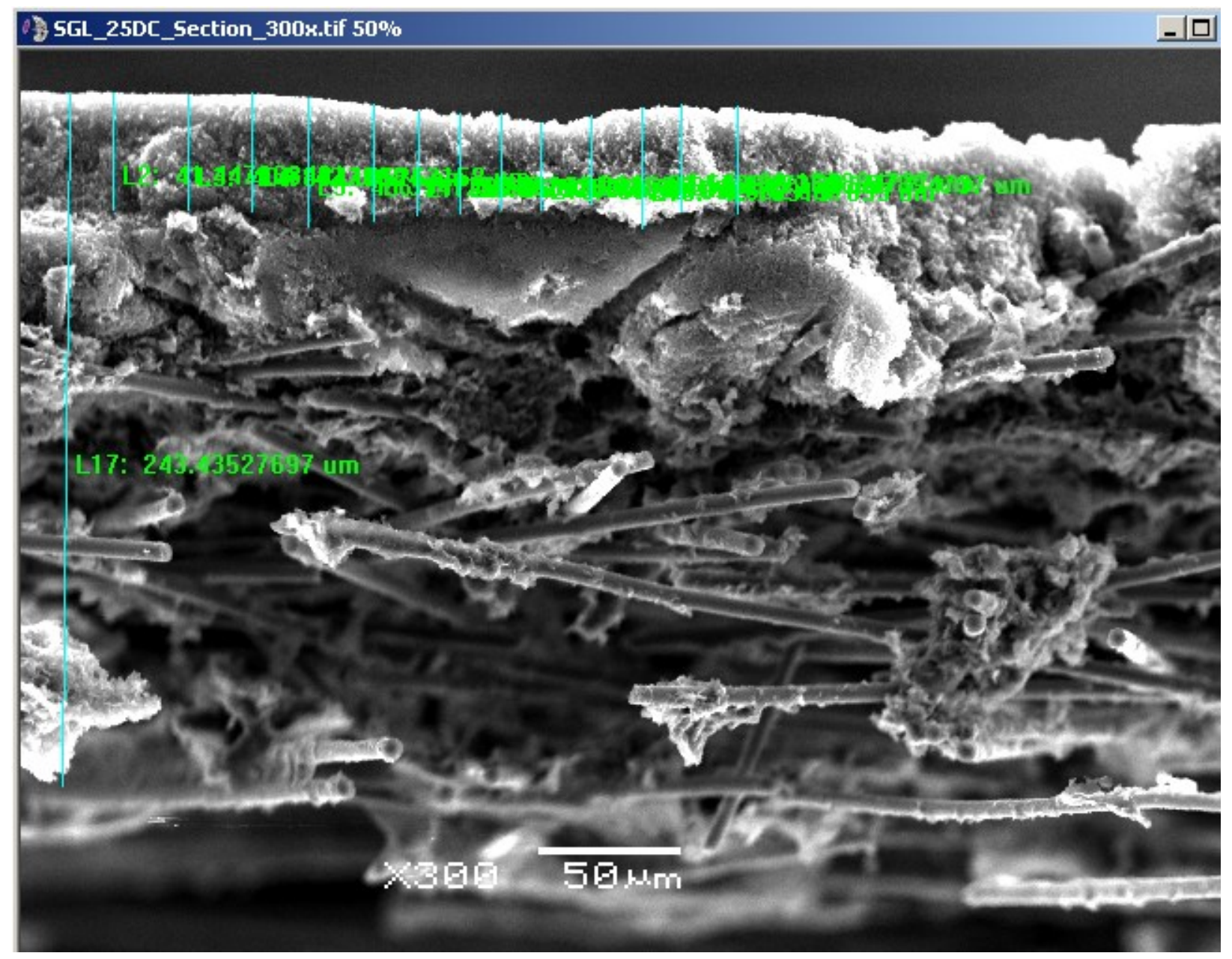

\begin{tabular}{|c|c|c|c|c|c|c|c|}
\hline & Features & Measurement & Value & Nominal Val. & Min. Tol. & Max. Tol. & Pass / Fail \\
\hline 1 & L2 & Length & 41.44736842 & 41.44737 & -0.000414 & 0.0004144 & Pass \\
\hline 2 & L3 & Length & 40.78947368 & 40.78947 & -0.000407 & 0.0004078 & Pass \\
\hline 3 & L4 & Length & 42.10526316 & 42.10526 & -0.000421 & 0.000421 & Pass \\
\hline 4 & L5 & Length & 45.39473684 & 45.39474 & -0.000453 & 0.0004539 & Pass \\
\hline 5 & L6 & Length & 41.44736842 & 41.44737 & -0.000414 & 0.0004144 & Pass \\
\hline 6 & L7 & Length & 36.84797886 & 36.84798 & -0.000368 & 0.0003684 & Pass \\
\hline 7 & L8 & Length & 35.52631579 & 35.52632 & -0.000355 & 0.0003552 & Pass \\
\hline 8 & L9 & Length & 34.21052632 & 34.21053 & -0.000342 & 0.0003421 & Pass \\
\hline 9 & L10 & Length & 30.92105263 & 30.92105 & -0.000309 & 0.0003092 & Pass \\
\hline 10 & L11 & Length & 31.57894737 & 31.57895 & -0.000315 & 0.0003157 & Pass \\
\hline 11 & L13 & Length & 42.7631579 & 42.76316 & -0.000427 & 0.0004276 & Pass \\
\hline 12 & L14 & Length & 38.15789474 & 38.15789 & -0.000381 & 0.0003815 & Pass \\
\hline 13 & L15 & Length & 38.15789474 & 38.15789 & -0.000381 & 0.0003815 & Pass \\
\hline 14 & L17 & Length & 243.435277 & 243.4353 & -0.002434 & 0.0024343 & Pass \\
\hline
\end{tabular}

